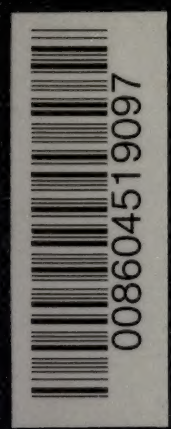




Digitized by the Internet Archive in 2007 with funding from Microsoft Corporation 


\title{
ESSAYS
}

\section{HISTORICAL AND LITERARY}

\author{
VOLUME I
}


The $1 \times$ <0. 



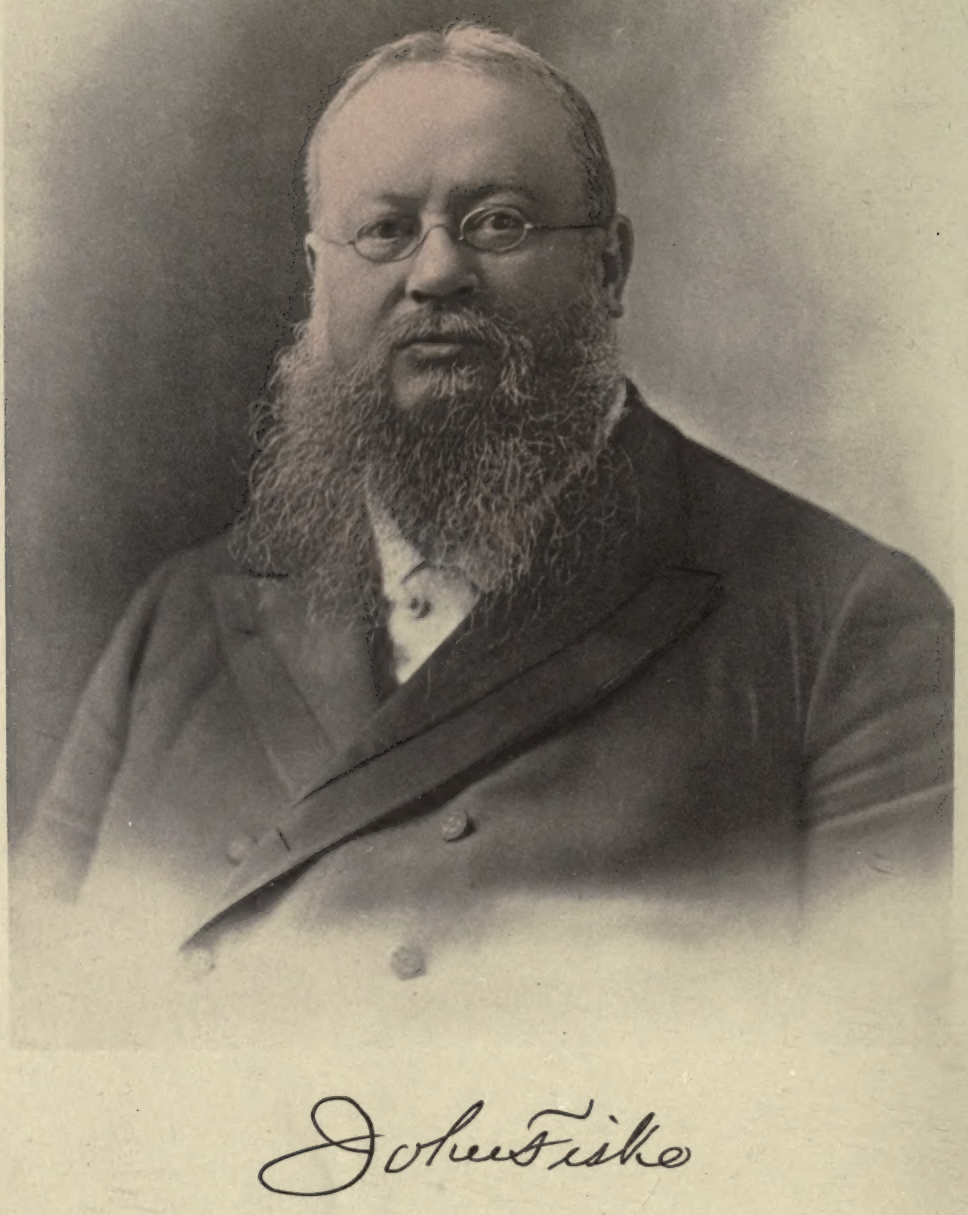




\section{Essays}

\section{Historical and Literary}

BY

JOHN FISKE

VOLUME I

SCENES AND CHARACTERS IN AMERICAN

HISTORY

"Study as if for Life Eternal, live prepared to die to-morrow."

- MONKISH PROVERB.

- Noem 19ark

THE 'MACMILLAN COMPANY

LONDON : MACMILLAN \& CO., LTD.

1902

All rigbts reserved 


\section{E \\ 176 \\ $\mathrm{F} 54$ \\ V.I}

COPYRIGHT, rgo2,

By THE MACMILLAN COMPANY.

Set up and electrotyped September, rgo2.

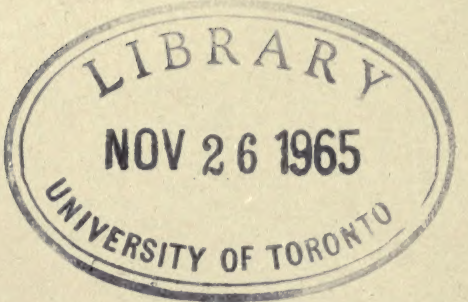

1025441

Norwood 杼ess

J. S. Cushing \& Co. - Berwick \& Smith Norwood Mass. U.S.A. 


\section{CONTENTS}

PAGE

I. Thomas Hutchinson, Last Royal Governor of Massachusetts . . . . . . . I

II. Charles Lee, Soldier of Fortune . . 53

III. Alexander Hamilton and the Federalist Party . 99

IV. Thomas Jefferson, the Conservative Reformer . 143

V. James Madison, the Constructive Statesman . 183

VI. Andrew Jackson, Frontiersman and Soldier . 219

ViI. Andrew Jackson and American Democracy Seventy Years Ago . . . . . . . . 265

VIII. Harrison, Tyler, and the Whig Coalition ("TipPeCANoe and Tyler too").". . . . . 315

IX. Daniel Webster and the Sentiment of Union $\cdot 363$

INDEX $\quad . \quad \cdot \quad \cdot \quad \cdot \quad \cdot \quad \cdot \quad \cdot \quad 4 \mathrm{I}$ 



\section{INTRODUCTION}

THE material in this volume was intended, by the Author, to be embodied in a greater work, A History of the American People. Many of these chapters were given by him as lectures in every part of our broad country, always enlarging and strengthening the bond of friendship with his people - who freely gave him such personal opinions, letters, and private documents as aided him in perfecting his historical work. Some of these letters, of especial significance, I have here included as notes.

Through the courtesy of D. Appleton \& Company, I am enabled to reproduce in the essays - Charles Lee, Thomas Jefferson, James Madison, Andrew Jackson, and Daniel Webster - biographical passages written by the Author for the Encyclopædia of American Biography.

ABBY MORGAN FISKE.

WESTGATE,

September 26, 1902. 

I

THOMAS HUTCHINSON

LAST ROYAL GOVERNOR OF MASSACHUSETTS 



\section{THOMAS HUTCHINSON}

\section{LAST ROYAL GOVERNOR OF MASSACHUSETTS}

ONE of the most encouraging features of the age in which we live is the rapidity with which the bitter feelings attendant upon a terrible civil war have faded away and given place to mutual friendliness and esteem between gallant men who, less than thirty years ago, withstood one another in deadly strife. Among our public men who hunger for the highest offices, a few Rip van Winkles are still to be found who, without sense enough to realize the folly and wickedness of their behaviour, try now and then to fan into fresh life the dying embers of sectional prejudice and distrust; but their speech has lost its charm, and those that bow the ear to it are few. The time is at hand when we may study the great Civil War of the nineteenth century as dispassionately as we study that of the seventeenth; and the warmest admirer of Cromwell and Lincoln may rejoice in belonging to a race of men that has produced such noble Christian heroes as Lucius, Viscount Falkland, and General Robert Lee. Such a time seems certainly not far off when we see how pleasantly the generals of opposing armies can now sit down and tell their reminiscences, and discuss each other's opinions and conduct in the pages of a popular magazine. 
Had the Civil War resulted in dividing the United States into two distinct nations, such an era of reconciliation would, of course, have been long delayed. With most people the sentiment of patriotism, which now extends, however inadequately, over the whole country, would then have become restricted to half of it. It would have been long before an independent Confederacy could have recognized the personal merit of men who strove with might and main to prevent its independence; and it would have been long before the defeated and curtailed United States could have been expected to admire the character or do justice to the motives of those who had shorn it of power and prestige. When one group of people owes its national existence to the military humiliation of another, the situation is very unfavourable for correct historical judgments, and it is apt to fare ill with the reputation of men who have been upon the unpopular side. Such, for the past hundred years, have been the relations between the United States and Great Britain, and accordingly many of the illustrious men of the Revolutionary period are still sadly misunderstood, in the one country if not in the other. The two foremost men of the time, the two that tower above all others in that century, Washington and Chatham, are indeed accepted as heroes in both countries; their fame is the common possession of the English race. The admiration which our British cousins feel for Washington is perhaps even more disinterested than that which we Americans feel for our eloquent defender, Chatham ; but in either case the homage is paid to transcendent greatness. In the portraits of too many of the actors upon our Revolutionary scene, the brush of 
partisan prejudice has obscured or distorted the true features. To this day British writers are apt to speak of Patrick Henry as a ranting fire-eater, and Samuel Adams as a tricksome demagogue; while upon the pages of American historians may be found remarks that, as applied to such high-minded gentlemen as Burgoyne or Cornwallis, are simply silly.

But of all the men of that day none have fared so ill as the American loyalists. They were not only out of sympathy with the declared policy of their country, but they were on the losing side. As a party they were crushed out of existence, as individuals they were driven into exile by thousands; and for a long time their voice was silenced. Liberal leaders in England, like Fox and Richmond, who hailed with glee the news of each American victory, were equally out of sympathy with the declared policy of their own country; but they were, nevertheless, a power in the land. The unanswerable logic of events was on their side; it was they that could say, "We told you so"; they represented principles that triumphed at Yorktown and were soon to triumph in England. The American loyalists, on the other hand, represented principles that have been irredeemably and forever discredited. They set themselves in opposition to the strongest and most wholesome instinct of the English race, the inborn love of self-government ; and they have incurred the fate which is reserved for men who diverge too widely from the progressive movement of the age in which they live. It becomes difficult for the next age to understand them, or to attribute their behaviour to anything but sheer perverseness. Yet among these American loyalists were men of noblest character and 
purest patriotism: and we need orly to divest ourselves for the moment of the knowledge of subsequent events which, in their day none could foresee; we need only to put ourselves back, in imagination, into the circumstances amid which their opinions were formed and their actions determined, in order to do justice to the deep humanity that was in them. We may dissent from their opinions, and disapprove their actions as heartily as ever; but it is our duty, as students of history, to take our stand upon that firm ground where, freed from the fleeting passions of a day, true manliness may be taken for its worth.

Among the American loyalists of the Revolutionary period there is perhaps none who has had such hard measure as Thomas Hutchinson. It may be doubted if any other American in high position, except Benedict Arnold, has ever incurred so much obloquy. But to couple these two names, even for a moment, is gross injustice to the last royal governor of Massachusetts. Alike for intellectual eminence and for spotless purity of character, there have been few Americans more thoroughly entitled to our respect than Thomas Hutchinson. It is sad indeed, though perfectly natural, that such a man should have had to wait a hundred years before his countrymen could come to consider his career dispassionately, and see him in the light in which he would himself have been willing to be seen. Let us take a brief survey of the personal history of this man; and as he belonged to a family distinguished in both the Old World and the New, let us begin with a glance at his ancestry.

In the English literature of the seventeenth century there are few books more charming than the memoirs 
of Colonel John Hutchinson of Owthorpe, written by his widow Lucy. Nowhere do we get a pleasanter picture of domestic life in the time of Charles I., or of the personality of a great Puritan soldier, than in those strong pages, glowing with sweet wifely devotion. This John Hutchinson, valiant defender of Nottingham and regicide judge, was eleventh in descent from Bernard Hutchinson, of Cowland, in Yorkshire, a doughty knight of the time of Edward I. From the same Bernard, apparently through Richard of Wyckham, in the sixth generation, in a chain of which one link still awaits complete verification, came Edward Hutchinson, of Alford, in Lincolnshire, who flourished in the reign of Elizabeth, but lived long enough to see hundreds of his friends and neighbours forsake their homes and set forth under Winthrop's leadership to found a colony in Massachusetts Bay. From one of Edward's younger sons are descended the Irish earls of Donoughmore, including the able general who, for overthrowing the remnant of Napoleon's army in Egypt in 1801, was first raised to the peerage as Lord Hutchinson. Edward's eldest son, William, born two years before the defeat of the Spanish Armada, was married in I6I2 to Anne Marbury, daughter of a Lincolnshire clergyman, a scion of the distinguished family of Sir Walter Blunt. Anne's mother was sister to Sir Erasmus Dryden, grandfather of the great poet.

William and his wife were warm friends and adherents of John Cotton, rector of St. Botolph's, and after that famous divine had taken his departure for New England, they were not long in following him. William's father, the venerable Edward, had died in I $_{3} \mathbf{I}$; and three years afterward, taking the widowed mother, 
Susanna, the wife, and fourteen children, William made his way across the Atlantic to Boston, where he proceeded to build a comfortable house on the site where now stands the Old Corner Bookstore. There, however, he was not destined long to dwell. The Antinomian heresy soon roused such fierce disputes as to threaten the very existence of the colony, and Mrs. Hutchinson, as the leading agitator, was tried for sedition and banished. Early in 1638 the family fled to the Narragansett country, where at first they were fain to seek shelter in a cave. But presently Mr. Hutchinson, with William Coddington and a few faithful followers, bought the island of Aquednek from the Indians for forty fathoms of white wampum, and forthwith the building of the towns of Portsmouth and Newport went on briskly. In 1642, when Mr. Hutchinson died, the outlook for the little colony was dubious. The New England Confederacy was about to be formed, and there were strong hints that the Rhode Island settlements, if they would share in its advantages, must put themselves under the jurisdiction either of Massachusetts or of Plymouth. Absurd and horrible tales were told about Mrs. Hutchinson, and found many believers. There were some who suspected her of being a paramour of Satan, and perhaps the fear of arrest on a charge of witchcraft may have had something to do with her next move. At all events, soon after her husband's death, the poor woman, with most of her children and a few friends, removed to a place since known as Pelham, a few miles west of Stamford and within the tolerant jurisdiction of the New Netherlands. There in the course of the following year they were all cruelly murdered by Indians, 
save one little ten-year-old daughter, Susanna, who was ransomed after four years of captivity.

In this wholesale massacre the eldest son, Edward, was not included. At the time of his mother's banishment he was twenty-five years old. $\mathrm{He}$ had lately returned from a visit to England, bringing with him a fair young bride who was admitted to communion with the First Church in Boston in December, 1638. While Edward's loyalty to his mother got him so far into trouble that he was heavily fined and sentence of banishment was passed upon him, we may imagine that his wife's orthodoxy may have helped him somewhat in making his peace with the magistrates of the Puritan commonwealth. At any rate he spent the rest of his life in Boston, where for seventeen years he was a deputy in the General Court. He was also the chief commander of horse in the colony, and in the summer of 1675 , after the disastrous beginning of King Philip's War, he was sent to Brookfield to negotiate with the Nipmuck Indians. The treacherous savages appointed the time and place for a rendezvous, but lay in ambush for Captain Hutchinson as he approached, and slew him, with several of his company.

Of Edward's twelve children, the eldest son, Elisha, came to be judge of common pleas and member of the council of assistants, and in r 688 was joined with Increase Mather, in London, in protesting against the high-handed conduct of Sir Edmund Andros. One of the earliest recollections of the royal governor was the great pomp of his grandfather Elisha's funeral on a bleak December day of I7I7, when the militia companies and the chief dignitaries of the province marched in stately procession to the place of burial. As Elisha 
left twelve children, the Hutchinson family in New England was getting to be a large one; and we find many of them in places of distinction and trust. Elisha's eldest son, Thomas, became a wealthy merchant and ship-owner. For twenty-six years he was a member of the council of assistants, and was noted for his resolute integrity and the fearlessness with which he spoke his mind without regard to the effect upon his popularity. He was also noted for a public-spirited generosity so lavish as to have made serious inroads upon his princely fortune. He has been called " "one of Boston's greatest benefactors." At his death, in I739, though still a very rich man, he lamented his inability to provide for his children on a scale commensurate with his wishes. One can readily believe that such families as these men had must have heavily taxed their resources. This Thomas Hutchinson's children were twelve in number, which seems to have been the normal rate of multiplication in that family. His wife, Sarah Foster, a lady of sterling character and sense, was daughter of Colonel John Foster, who took an active part in the insurrection which overthrew the government of Andros. Their fourth child and eldest surviving son, Thomas, most illustrious and in some respects most unhappy of this remarkable family, was born on the gth of September, I 7II, in that stately house in the old north end of Boston to which our attention will by and by again be directed. At five years of age the little Thomas began to con his multiplication table and spelling-book in the North grammar school on Bennet Street, which his father had lately founded, and over the lintel of which were en-

${ }^{1}$ E. G. Porter, "Rambles in Old Boston," p. 205. 
graved the arms of the Hutchinsons of Lincolnshire. Thus in daily going out and in at the door, as in the vague wonder of the grandsire's stately funeral, may the thoughtful and impressible child, in somewhat the mood of a generous little prince, have come to feel himself identified with the civic life of Boston. Of adulation for such boys there is usually enough and to spare; but Thomas Hutchinson was not of the sort that is easily spoiled. In the writings of his later years, amid all the storm and stress of a troubled life, nothing is more conspicuous than the absence of personal vanity and the sweetness of temper with which events are judged aside from their bearings upon himself.

In the simple school life of those days there were not so many subjects to be half learned as now, and boys became freshmen at a very tender age. Hutchinson was barely sixteen when he received his bachelor's degree at Harvard, and in after years he frankly confessed that he could not clearly see what he had done to earn it. At first the ledger interested him more than the lexicon. He carried on a little foreign trade by sending ventures in his father's ships, and thus earned enough money to have defrayed the whole cost of his education, while at the same time he became an expert in bookkeeping. In those days Harvard students were graded according to social position. Early in the freshman year a list of names was hung in the college buttery, and those at the top were allowed the best rooms and other privileges. Usually this list remained without change, and it is in this order that the names appear on the triennial catalogue until 1773, when the democratic alphabet took its 
place. In the class of 1727 , which numbered thirtyseven students, the only names above Hutchinson's were those of the two Brownes, one of whom was afterward son-in-law of Governor Burnet and father of one of the "mandamus councillors" of I774. Another distinguished member of the class was Jonathan Trumbull, the great "war governor" of Connecticut and valued friend of Washington, and according to one tradition, the original "Brother Jonathan."

It was after Hutchinson had left college, and become an apprentice in his father's counting-room, that the scholarly impulse seized and mastered him. He fell in love with the beauties of Latin, and diligently used his leisure evenings until he had become fairly accomplished in that language; to this he soon added a practical knowledge of French. Of history he was always fond. As a child he would rather curl down in the chimney corner and pore over Church's "Indian War" and Morton's "New England Memorial" than coast and snowball with boys in the street; and his Puritan education did not prevent him from shedding tears over the sufferings and death of King Charles. The seventy-fours and frigates that now and then sailed into Boston harbour, stately and beautiful, and symbolic of England's empire, had a special charm for him. In their snug cabins he found agreeable companions, among them Lieutenant Hawke, afterward to be known as one of the greatest of British sea kings. Still pleasanter society was found in the household of a widow lady, with three beautiful daughters, who had lately moved to Boston from Rhode Island. To Margaret Sanford, the second daughter, aged seventeen, Hutchinson was married in 1734 . In the course 
of the following year he became a member of the Congregational church on Hanover Street, known at that time as the New Brick Church. Throughout his life he was strictly religious, according to the Puritanism of the eighteenth century, which in Massachusetts had already come to be much more genial and liberal than that of the seventeenth.

Hutchinson's public life began soon after his marriage. In his diary he tells how much pleasure he felt when, in his twenty-sixth year, he was chosen a selectman for the town of Boston, and a few weeks later a representative in the General Court. 'But his public career was stormy from the outset. The people were then greatly agitated over the question of paper money. As long ago as I69o, upon the return of Sir William Phips from his disastrous expedition against Quebec, Massachusetts had issued promissory notes, called bills of credit, in denominations from $2 s$. to $£ \mathrm{IO}$; they were receivable for sums due to the public treasury. The inevitable results followed. The promissory notes issued by a government which had no cash for paying its debts, and because it had no cash, of course fell in value. Coin was therefore driven from circulation, and there was a great inflation of prices, with frequent and disastrous fluctuations. The disturbance of trade became serious, and then, as always, tricksome demagogues played upon the popular ignorance, which sought a cure for the disease in fresh issues of paper. Pretty much the same nonsense was talked in I 737 as afterward in 1786 , and yet again in 1873 . The trouble extended over New England, and it is curious to observe, between three of the states, the same differences of attitude as in the great crisis of 
I786. In Connecticut the advocates of paper money made but little headway. In I 709 and I7I 3 bills of credit were issued, but in such small amount and with such judicious and stringent measures for redemption that the depreciation was but slight, and specie payments were resumed with little difficulty. In Rhode Island, on the other hand, rag money won an easy victory, and the resulting demoralization lasted through the century, until after the adoption of the Federal Constitution. In Massachusetts parties were more evenly divided, but whereas in 1786 the advocates of paper were in the minority, in 1737 they had a decided majority. They were the popular party, and especially so after their policy had led to complaints from British merchants trading with Massachusetts, until the royal governor, Jonathan Belcher, was ordered by the Lords of Trade to veto any further issue of bills of credit. A quarrel ensued between Belcher and his legislature, and as the governor proved inexorable, wildcat banking schemes were devised to meet the emergency. The agitation was coming to a crisis when Hutchinson took his seat in the House. Upon all financial questions he had a remarkably clear head, and there was nothing of the demagogue about him. He would not palter with a question of public policy, or seek to hide his opinions in order to curry favour with the people. He was a man to whom strong convictions and dauntless courage had come by inheritance, and as his great-grandfather Edward had stoutly opposed the persecution of the Quakers, so now the greatgrandson opposed the paper money delusion with untiring zeal. His conduct was the more noteworthy in that representatives were at that time in Massachu- 
setts regarded as mere deputies, in duty bound to give voice to the wishes or whims of the voters that sent them to the legislature. The liberty accorded to them of using their own judgment was narrow indeed. In spite of his independence, Hutchinson was reëlected in $173^{8}$; but soon afterward in town meeting a set of instructions were reported, enjoining it upon the representatives of Boston to vote for the further emission of paper. This measure was intended to curb the refractory young man, but it only called him at once to his feet with a powerful speech, in which he denounced the instructions as foolish and wicked, and ended by flatly refusing to obey them. Indignant murmurs ran about the room, and one wrathful voice shouted, "Choose another representative, Mr. Moderator!" But this was too silly; it was not for the presiding officer of a town meeting to seat or unseat representatives. There was no help for it until next year, when Hutchinson, who had been as good as his word, was defeated at the polls. About this time a typhoid fever struck him down, and for several weeks he was at death's door. He had three very eminent physicians, either of whom might have sat for the portrait of Dr. Sangrado, but by dint of an ample inheritance of vitality he withstood both drugs and disease; and presently, taking counsel of a sensible friend, threw physic to the dogs, and recovered strength by means of a judicious diet and horseback rides in the country. One of the doctors lost his temper and stormed about empirics and quacks; the others showed more candour. When Hutchinson found himself able again to attend to business, the general confidence in his uprightness and ability prevailed over the dislike 
of his policy, and he was again chosen representative.

In this year, 1740 , there was an outburst of excitement in Boston not unlike those that ushered in the Revolutionary War. Of the wildcat banking schemes, two were especially prominent. The one known as the "Specie Bank" undertook to issue $\mathscr{E}_{\mathrm{I}} \mathrm{I} \mathrm{0}, \mathrm{000}$ in promissory notes, to be redeemed at the end of fifteen years in silver at $20 \mathrm{~s}$. per ounce; but it was not altogether clear from what quarter this desirable silver was to come. There is something pathetic about these persistently recurring popular fancies, based on a still surviving faith in that old Norse deity to which our heathen forefathers did reverence as the god Wish! The rival scheme, known as the "Land Bank," undertook to issue $\mathcal{E} \mathrm{I} 50,000$ in promissory notes, redeemable at the end of twenty years in manufactures or produce. There were about eight hundred stock-holders, or partners. Each partner mortgaged his house or farm to the company, and in return for this security borrowed the company's notes at three per cent interest. $\mathrm{He}$ was to pay each year not only the interest, but one-twentieth part of the principal; and payment might be made either in the same notes or else in merchandise at rates assigned by the directors of the company. ${ }^{1}$ The exploit of "basing" a currency on nothing and "floating" it in the air was never more boldly attempted. As a means of transacting business in a commercial society, a note payable in another note, or in whatever commodity might after twenty years happen to be cheapest, must have been a device of scarcely less efficiency than the far-famed philosopher's stone. A man who sold one hundred bushels ${ }^{1}$ Palfrey, IV. 550; Sumner, "American Currency," 29. 
of wheat for such a note would have such a precise knowledge of how much it was going to be worth to him! But in financial matters, where the wish is so apt to father the thought, there seems to be no delusion too gross to find supporters. By 1740 the Land Bank and the Specie Bank had both been put into operation, in spite of Governor Belcher, who dissolved the assembly, cashiered colonels, disbenched justices, and turned out office-holders to right and left, for the offence of receiving and passing the notes; and presently a flagrant political issue was raised. Finding that paper professing to represent at least $£ 50$,000 had been issued by the Land Bank, the governor appealed to Parliament for help, and in this he was upheld by some of the best men in Massachusetts. This was in Walpole's time, and his Parliaments handled American affairs more delicately than those of George III.; it happened that a new statute expressly for this occasion was not needed. Twenty years before, upon the collapse of the famous South Sea Bubble, an act had been passed forbidding the incorporation of joint stock companies with more than six partne̊rs. Parliament now simply declared that this act was always of force in the colonies as well as in Great Britain. The two Massachusetts companies were thus abruptly compelled to wind up their affairs and redeem their scrip; and as the partners were held individually liable, they incurred heavy losses, and would have been quickly ruined if the claims against them had been rigorously pressed. One of the directors of the Land Bank, and perhaps the wealthiest of its partners, was the elder Samuel Adams, deacon of the Old South Church, and one of the justices of the 
peace whom Belcher had displaced. A considerable part of his fortune melted away in a moment, so that his famous son, who was that summer in the graduating class at Harvard, may be said in a certain sense to have inherited his quarrel with the British government. It is interesting, in this connection, to remember how, three years later, as a candidate for the master's degree, young Samuel Adams chose as the subject of his Latin thesis the question, "Whether it be lawful to resist the supreme magistrate if the commonwealth cannot otherwise be preserved?" and this bold question he answered in the affirmative, while the new royal governor, Shirley, as guest of the college on Commencement Day, sat on the platform and heard him. The question as to the authority of Parliament over the colonies, which had for a moment attracted attention as long ago as I644, was now more warmly agitated. The friends of the Land Bank loudly denounced the declaratory act of $\mathrm{I} 740$ as a violation of the chartered rights of Massachusetts, and the bitter feelings engendered by this affair must unquestionably be set down among the causes of the American Revolution. Hutchinson's conduct at this time was eminently wise and patriotic. On theory he was then, as always, a firm believer in the ultimate supremacy of Parliament over every part of the British empire. $\mathrm{He}$ understood better than most Americans of his day that the supremacy of the crown was figurative rather than real. He believed that if sovereignty over the whole did not reside somewhere, the unity of the empire was virtually at an end; and where else could such sovereignty reside if not in Parliament? At the same time he shared with many other able and thought- 
ful men in the fear that, if the protecting hand of Great Britain were once removed, the colonies would either fall a prey to France or Spain, or else would tear themselves to pieces with internecine wars; and who is there that can read the solemn story of the impending anarchy from which Washington and Madison and Hamilton saved the people of these states in the anxious years that followed the victory at Yorktown, and then say that such forebodings were wholly unreasonable. It is easy to be wise after the event; but in distributing the meed of praise and blame, the historian must bear in mind the aspect of things in the times which he seeks to describe, when events, now as familiar as our daily bread, were as yet in the darkness of the future, undreamed of and improbable. Nothing can be clearer to-day than that Hutchinson's fundamental theory was wrong. He failed to take in the situation, and paid so heavy a penalty for his failure that we can well afford to give him due credit for the wisdom and good feeling which in some respects he did show to an eminent degree. Like Dickinson and Burke, he realized that the question of the ultimate supremacy of Parliament was a dangerous one to insist upon. He saw distinctly the foolishness of enlisting such a wholesome feeling as the love of self-government in behalf of such a wretched concern as the Massachusetts Land Bank; and he earnestly advised Governor Belcher to bide his time, and trust in accomplishing its downfall in some other way than by a direct appeal to Parliament. Surely Belcher, as an ambitious politician, undervalued the counsel of this young man of nine and twenty, for the immediate result of his violent conduct was his own downfall; 
to appease the popular indignation, the same British government that sustained his policy transferred him to the inferior position of governor of New Jersey, and put William Shirley, a man of more tact, in his place. But the legacy of distrust and discontent remained. This was the first, but not the last, time that serious trouble between England and America was brought about by disregarding Thomas Hutchinson's advice.

In the midst of this controversy Hutchinson was intrusted by his fellow-citizens with an important mission. The boundary line between Massachusetts and New Hampshire had for some time been matter of dispute, and he was sent over to England to adjust the affair. His conduct seems to have been satisfactory, but his diary gives little information as to the details of what he saw and did in the mother country, save that homesickness assailed him, and that in all his life he could not "remember any joy equal to that of meeting his wife again," after an absence of thirteen months. On his return he was chosen representative, and was annually reëlected until I 749. In I 746 and the two following years he was Speaker of the House, and in this capacity he came once more into conflict with popular prejudice, and for a long time to come enjoyed a well-earned triumph. By the treaty of Aixla-Chapelle in 1748 the stronghold of Louisburg, which New England troops had captured in I745, was restored to France in exchange for Madras in Hindustan.

In an empire extending over half the globe, it was not always easy to reconcile imperial with local interests. The people of New England were naturally indignant. Their capture of Louisburg was the first 
event that awakened Europe to the fact that in the western hemisphere a new military power had come into existence. The place had, moreover, a great strategic value in its relations to New England and Canada, and we can well understand the wrath that greeted the news that this important conquest had been bartered away for a heathen city on the other side of the globe. To appease the popular indignation, Parliament voted that adequate compensation should be made for the expense of the capture of Louisburg. The sum due to Massachusetts in pursuance of this vote was $£ \mathrm{I} 38,649$, which was nearly equivalent to the total amount of paper then circulating in the colony at its current valuation of oneeleventh of its face value. To attempt to raise such a currency to par was hopeless. Hutchinson proposed in the assembly that Parliament should be asked to send over the money in Spanish dollars, which should be used to buy up and cancel the paper at eleven for one. Whatever paper remained after this summary process should be called in and redeemed by direct taxation, and any issue of paper currency in future was to be forbidden. "This rather caused a smile," says the diary, "few apprehending that he was in earnest; but upon his appearing very serious, out of deference to him as Speaker, they appointed a committee." After a year of hard work, Hutchinson's bill was passed, amid the howls and curses of the people of Boston. "Such was the infatuation that it was common to hear men wish the ship with the silver on board might sink in her passage." They wanted no money but rag money. At the election in 1749 Hutchinson was defeated by a great majority, but was imme- 
diately chosen a member of the council. People soon found, to their amazement, that a good hard dollar had much greater purchasing power than a scrap of dirty paper worth about nine cents; and it was further observed that, when an inferior currency was once out of the way, coin would remain in circulation. The revival of trade was so steady and so marked that the tide of popular feeling turned, and Hutchinson was as much praised as he had before been abused. His services at this time cannot be rated too highly. To his clear insight and determined courage it was largely due that Massachusetts was financially able to enter upon the Revolutionary War. In I 774 Massachusetts was entirely out of debt, and her prosperity contrasted strikingly with the poverty-stricken condition of Rhode Island, which persisted in its issues of inconvertible paper. It was then that the West India trade of Massachusetts, a considerable part of which had hitherto been carried on through Newport, was almost entirely transferred to Boston and Salem.

About this time Hutchinson was cherishing an intention of giving up all mercantile business and dealing but little more with practical politics. On the summit of Milton Hill, seven miles south of Boston, in one of the most charming spots in all that neighbourhood, he had built a fine house, which still stands there, though largely reconstructed. Sitting at its broad windows, or walking upon the velvet lawn under the shade of arching trees, one gets entrancing views of the Neponset River, with its meadows far below, and of the broad expanse of the harbour studded with its islands and cheery with white-winged ships. To this earthly paradise, Hutchinson, having 
passed his fortieth birthday, was hoping soon to retreat with his wife and children, there to spend the remainder of his days in his favourite historical studies and in rural pursuits. Like two eminent historians of our own time, Mr. Bancroft and Mr. Parkman, he was an expert at gardening and had a passion for flowers. But it is not so easy to tear oneself away from public life. In the spring of $175^{2}$, the death of his uncle, Edward Hutchinson, left vacant the offices of judge of probate and justice of common pleas for the county of Suffolk, and the nephew accepted an appointment to fill these places. Two years afterward he met with an overwhelming affliction in the sudden death of his wife, at the age of thirty-seven. For twenty years their life had been so happy that the remembrance of it kept him ever after from the mere thought of another marriage. He now sought relief from sorrow in increased devotion to public affairs. In that same year, I 754, he was one of the delegates to the memorable Congress at Albany, where he was associated with Franklin on the committee for drawing up a plan of union for the thirteen colonies. It is pleasant for a moment to see these two eminent men working together in a friendly spirit, little dreaming of their future estrangement. For the conception of the famous Albany Plan, Hutchinson gives the credit entirely to Franklin. At that time the views of the two were in harmony. No one had as yet thought seriously of such a thing as separation from the British empire. If this sagacious scheme for a federal union of the thirteen colonies, with a parliament or grand council of their own, a viceroy appointed by the crown, and local self-government guaranteed to the people, 
could have been once put into successful operation, the history of the next half-century would have been very different from what it was. There would probably have been no Stamp Act, no Committees of Correspondence, no Boston Tea Party, perhaps no Revolution. It is idle to pursue such speculations. A general acquaintance with history would lead one to doubt if, under a federal union thus formed, and hampered by connection with a remote imperial government, the political career of the American people could have been worked out with as much success as that which we have actually witnessed. But we need not go so far as this, inasmuch as any plan whatever for a federal union, in 1754 , was premature and impracticable. Men like Franklin and Hutchinson might see the desirableness of such a thing, but people in general did not see it. The time for constructive national politics on this grand scale had not arrived; and probably nothing but hardship would have brought it. It is only through pain that higher and higher forms of life, whether individual or social, are evolved.

In 1757 Shirley was succeeded in the governorship of Massachusetts by Thomas Pownall, and the next year Hutchinson was appointed lieutenant-governor. Under the management of William Pitt the fortunes of the world-wide war against France were now suddenly changed. "We are obliged to ask every day," said Horace Walpole, "what new victory there is, for fear of losing one." Hutchinson's energy and popularity made him of great service in calling out the military resources of Massachusetts, and in these campaigns the province began to awaken to a consciousness of 
its strength. Pownall stayed only till I 760, when he was replaced by Francis Bernard, who, soon afterward, on the death of Stephen Sewall, appointed Hutchinson chief justice of Massachusetts, much to the disgust of the elder James Otis, who desired the position and expected to obtain it. In later days Hutchinson was charged with greed of office, because he was at once judge of probate, member of the council, chief justice, and lieutenant-governor. Still later the charge of avarice has been thoughtlessly added by writers forgetful of the facts that he was liberal in money matters, far too rich to be attracted by the meagre salaries of these laborious offices, and as a scholar somewhat inclined to be miserly of his time. The explanation is rather to be found in his inheritance of public spirit and rare ability, combined with the general favour won by genial manners and unblemished purity of life. For twenty years he was the popular idol of Massachusetts, and was wanted for all sorts of things. There may seem something strange in appointing to the chief justiceship a man who had not practised at the bar, instead of a lawyer so eminent as Otis. But Hutchinson's eight years' service as judge of a county court had shown that, along with a judicial temper, he possessed an extraordinarily wide and accurate knowledge of law; and when Bernard appointed him chief justice he did so at the earnest request of several leading members of the bar, headed by Jeremiah Gridley, one of the greatest lawyers of that age.

On a December day of $\mathrm{I} 760$, soon after this appointment was made, the news came to Boston that King George II. was dead and his youthful grandson had 
ascended the throne as George III. No one could then have dreamed what this announcement portended. But soon there followed the news of Pitt's resignation, and the next three years saw the abandonment of the whole grand policy in support of which British and American troops had for the last time stood side by side, and its replacement by that domestic struggle for supremacy between the king and the Whig families, out of which grew some of the immediate causes of the American Revolution. In the year i 76I there appeared in the horizon the little cloud like unto a man's hand which came before the storm. This was the famous argument on the writs of assistance enabling revenue officers to enter houses and search for smuggled goods. In this case, in which Hutchinson presided and Gridley appeared for the crown officers, the younger James Otis made the startling and prophetic speech in which he showed successfully that the issue of such writs was contrary to the whole spirit of the British constitution. According to the letter of the law, however, the case was not so clear. Such general search-warrants had been allowed by a statute of Charles II., another statute of William III. in general terms here granted to revenue officers in America like powers to those they possessed in England, and neither of these statutes had been repealed. As to the legality of the writs there was room for doubt; and Hutchinson accordingly suspended judgment until the next term, in order to obtain information from England as to the present practice there. In accordance with advice from the law officers of the crown, the writs were finally granted. Here, as in other yet weightier matters which were 
hereafter to come up for fierce debate, it was becoming apparent that the real question was concerned with something even more fundamental than the interpretation of the law. The real question was whether Americans were bound to obey laws which they had no voice in making. An out-and-out issue upon this point was something that Hutchinson dreaded as anxiously as Clay and Calhoun, in their different ways, dreaded an out-and-out issue upon the slavery question. He earnestly deprecated any action of Parliament which should encroach upon American self-government; and by the same token he frowned upon such action on the part of his fellow-citizens as might irritate Parliament, and provoke it into asserting its power. Should the issue be raised, he felt that the choice was between anarchy and submission to Parliament, and that the very love which he bore to Massachusetts must urge him to a course that was likely to deprive him of the esteem of valued friends, and heap cruel imputations upon his character and motives. Such questions of conflicting allegiance have no pity for men in high positions. They were fraught with sorrow to Thomas Hutchinson as to Robert Lee, and many another noble and tender soul.

- It was natural, therefore, that when the Grenville ministry began to talk about a stamp act, Hutchinson should have done his best to dissuade them from such a rash measure. Here, as before, if his advice had been taken, much trouble might have been avoided. As a high public official, however, he could not with propriety blazon forth what he was doing, and many people misunderstood him. He condemned the resistance which was beginning to organize itself under 
the leadership of Samuel Adams, as tending inevitably toward counter-resistance and strife. Such an attitude was liable to be interpreted as indicating tacit approval of the Stamp Act. At this juncture an unfortunate incident served to direct upon him the rage of the rough populace that swarmed about the wharves and waterside taverns of the busy seaport. The enforcement of the Navigation Acts had already made much trouble in Boston, and in more than one instance warehouse doors had been barricaded and the officers successfully defied. Governor Bernard had become very unpopular through his zeal in promoting seizures for illicit trade, which he was supposed to have made quite profitable by his share in the forfeitures. In the ordinary course of business concerning these matters, depositions were made before Chief Justice Hutchinson, and attested by him. In Bernard's reports to the Lords of Trade, such depositions were sometimes sent over to London as evidence of the state of affairs, and were placed on file at the Plantation Office. There it happened that Briggs Hallowell, a Boston merchant, saw some of these documents in which John Rowe and others of his fellow-citizens were mentioned by name as smugglers. Reports of this reached Boston in the summer of 1765 , on the very eve of the Stamp Act riots.

The house in which Hutchinson still continued to dwell when in town was his father's home, where he had been born. It stood between Garden Court and Hanover Street, next to the house of Sir Harry Frankland, in a neighbourhood from which the glory has long since departed. At that time it was probably the noblest dwelling-house in America, for along with 
its rich furnishings and works of art it contained the superb library which its owner had for thirty years been collecting, and which included many precious manuscripts illustrating our early history, - documents for a sight of which to-day the historical student would deem their weight in diamonds a cheap price. On the oaken desk which stood amid these crowded shelves the ink was hardly dry upon the last pages of the second volume of that "History of Massachusetts" which remains to-day one of the most admirable histories ever written by an American. The first volume, bringing the story down to the accession of William III., was published in 1764 ; the second, continuing the narrative to $\mathrm{I} 75 \mathrm{O}$, was now about to go to press, when riot and confusion burst in upon the scene. On the I $4^{\text {th }}$ of August the Sons of Liberty paraded through the streets, in just and rightful expression of indignation at the Stamp Act. Nothing violent was done, though the beams of a house just going up, and supposed to be intended for a stamp office, were pulled down and used for a bonfire. By the next night more disreputable elements were at work. A mob surrounded Hutchinson's house, and shouted to him to come out and deny, if he could, that he had advised and abetted the Stamp Act. But this he refused to do. It was not for him to yield to a demand made in such a spirit. Upon compulsion, he, like Gabriel Varden, would do nothing. An aged merchant hereupon harangued the crowd, and assured them that they were quite in the wrong; Mr. Hutchinson disapproved the Stamp Act, and was in no wise responsible for it. So for that night all passed quietly, but during the next week vague, ill- 
understood rumours from London wrought their effect upon the mob. On the night of the 26th a bonfire in King Street gathered a crowd together. First they broke into the cellars of the comptroller of customs, and drank freely from the rum and brandy casks stored there. Then a fury for punishing informers seized them, and they rushed to the chief justice's house. A few blows with broadaxes split the doors and window-shutters, and the howling, cursing rabble swarmed in. Their approach had been heard some minutes before, and Hutchinson had told his children to flee; but his eldest daughter refused to go without him, and while she was expostulating with him, the doors were broken in. Carrying her in his arms, he fled across the garden to the house of his brother-inlaw, the Rev. Samuel Mather, leaving the mob in full possession. Pictures were cut to pieces, mirrors smashed, wearing apparel and silver stolen, and priceless books and manuscripts flung into the street. The halts made from time to time in the well-stocked winebins served to keep up and enhance the fury, until before daybreak even the partition walls had been partly torn down, and great breaches had been hacked in the brickwork. By sunrise the crowd had dispersed, and friendly hands had begun searching for the treasures of the ruined library. The manuscript of the second volume of the history, scattered hither and thither, and drenched in a midnight shower, was picked up and carefully put together by the Rev. Andrew Eliot, so that the author found little difficulty in restoring it, and it was published two years later.

The next morning, before Governor Bernard could summon the council, a huge town meeting in Faneuil 
Hall declared by a unanimous vote its abhorrence of the shameful work of the night. It was the opening day of the session of court, and the chief justice, whose wardrobe had perished, came to the bench in his loosegown, and with the quiet dignity that never deserted him pointed out to the crowded audience the wickedness of the misunderstanding of which he had been made the victim. Court adjourned till order could be restored. Town meetings throughout Massachusetts condemned the mob. Several ringleaders were arrested and sent to jail, but another mob released them. The disorder was not fully abated until the gth of September, when news came from England that the Grenville ministry had fallen. The advent of Lord Rockingham as prime minister gave hope that the Stamp Act policy would be reconsidered, and for two years quiet was restored in America. A bill for the relief of persons who had suffered from the riots was passed by the Massachusetts assembly, and Hutchinson's damages were repaired, so far as might be, in money. The loss of materials for the student of American history was something that could never be repaired.

In the year of the Stamp Act Samuel Adams was chosen a member of the legislature. The exclusion of crown officers from a seat in either branch of that body had for some time been one of his favourite ideas, and in 1766 he so far succeeded in realizing it that Hutchinson, with four others, failed to be elected to the council. The last two years of Bernard's administration, 1768 and 1769 , were full of strife and bitterness. The news of Charles Townshend's measures led to the famous resolutions of 1768 and the circular letter inviting the other colonies to resistance. Then 
came the demand from the ministry that the circular letter should be rescinded, to which the Massachusetts assembly replied with a flat refusal, and was forthwith turned out of doors by the governor. Then, in order to catch Samuel Adams and carry him to England for trial, there was the revival of a half-forgotten act of Henry VIII., about treason committed beyond sea. The two regiments which were landed in Boston in the autumn of I 768 came at Bernard's solicitation, to aid the crown officers in preserving order. Such an event as the sacking of Hutchinson's house went far toward creating an impression in England that such assistance was necessary. The intention of the government in sending the troops was no doubt innocent enough; but it would have been hard to hit upon a more dangerous measure, or one revealing a more hopeless ignorance of the American character. It could not be regarded otherwise than as a threat, and it put Great Britain into somewhat the attitude of a man who, in the course of an argument with his friend, suddenly draws a pistol. An intelligent and disinterested government might have asked itself the question whether it were a wise policy to keep up an odious revenue law that in such an orderly town as Boston made it necessary to introduce soldiers to prevent disorder. But not only was the government neither intelligent nor disinterested, but it was entirely natural to argue that a town whose magistrates could not prevent the sacking of private houses did not deserve to be called an orderly town. As for Hutchinson himself, he would have been more than human if such considerations had not coloured his own view of the case, although the serenity and sweetness of temper 
with which, in his history, as also in his private diary, he speaks of his personal hardships, are very remarkable. The pages of these charming books show the thoroughbred Christian gentleman. But as a statesman he was far from reading the temper of the people correctly. He knew that in the violence which touched him so nearly the sympathy of the people was not with the rioters. He felt that all the troubles were due to the unreasonable obstinacy of a few such men as James Otis and Samuel Adams; and that if these men could be defeated, the general sense of the people would be in favour of peace and quiet. In this opinion he misconceived the facts of the situation very much as they are misconceived to-day by such well-meaning British writers as Mr. Lecky and Mr. Goldwin Smith. With all their fairness toward America, these writers are still blind to the fact that the issues raised by George III. and his ministers - in the Stamp Act of 1765 , in the Townshend acts of 1767 , in the measures concerning the salaries of crown officers in 1772 , and finally in the vindictive acts of $\mathrm{I} 774$ after the Boston Tea Party - were one and all of them such issues as the Americans could not for a moment accept without shamefully abandoning the principles of free government for which the whole English race has been manfully striving since the days of Magna Charta. If British historians, sincerely desirous of doing justice to America, find it hard to understand these things to-day, perhaps it was not strange that some able men like Hutchinson did not understand them at a time when the baleful policy and selfish aims of George III. were still dimly viewed through the mists of contemporary prejudice and passion. Hutchinson's own 
views were thus expressed in a private letter to a friend in Dublin, early in I772, "It is not likely that the American colonies will remain part of the British dominion another century, but while they do remain, the supreme absolute legislative power must remain entire, to be exercised upon the colonies so far as is necessary for the maintenance of its own authority and the general weal of the empire, and no farther." This was moderately expressed; probably at that moment neither Dickinson nor Franklin would have taken serious exception to it. Yet the argument could not be pushed without involving the surrender of the American cause. It does not appear that Hutchinson was anxious to push it, or that he courted the position of chief upholder of Toryism in America; but the attitude of mind that went naturally along with his official position could hardly fail to drive him in this direction. In the summer of 1769 Governor Bernard was recalled to England, to appease the people of Massachusetts, while his own feelings were assuaged with a baronetcy. Before his ship had weighed anchor in the harbour, the sound of clanging bells and booming cannon told him of the fierce rejoicings over his departure. The administration of affairs was left in the hands of Hutchinson as lieutenant-governor, and it was not long before the course of events was such as to show, with vivid and startling suddenness, the false position into which he was drifting. In the fatal squabble between soldiers and townspeople on that memorable moonlit evening in March, I 770, he showed vigour and discretion, and but for his prompt arrest of the offending soldiers the affair might have grown into something which it would have been no misnomer 
to call a "massacre." But next morning, when he looked out from the window of the town house, and saw the surging crowd of people in King Street, on their way from Faneuil Hall to the Old South Church, and when he exclaimed that their spirit seemed to be as high as that of their ancestors when they rose against Andros, one cannot but wonder if his thoughts did not go back for a moment to the winter day when as a little child he had stood by the grave of the grandfather who had stoutly opposed that agent of tyranny. Did it seem quite right for the grandson, with whatsoever honest intent, to be standing in Andros's place? A few hours later, when Samuel Adams, for the second time that day, came into the council chamber, with the final message from the people, and with uplifted finger solemnly commanded Hutchinson to remove all soldiery from Boston, the king's representative obeyed. That his knees trembled and his cheeks grew pale, as Adams afterward told, we may well believe. Not from fear, however, but more likely from a sudden sickening sense of the odium of his position. Not long afterward he wrote to London, asking to be relieved of all further share in the work of administration. But before the letter was received his commission as royal governor of Massachusetts had been drawn up. Lord North was at this time earnest in the wish to pursue a conciliatory policy, and Hutchinson was appointed governor because it was supposed that the people would prefer his administration. Indeed, except for the unfortunate affray in King Street, the departure of Bernard already seemed to have done much to clear the air. After the troops had been sent out to the Castle, there was a general sense of relief, and many 
people entertained hopes that the troubles were over. In reply to Hutchinson's letter, the ministry told him to take his own time to consider whether or not he would accept the appointment; and it was during this lull in the storm, toward the end of I770, that he decided to accept it. He might well believe that under his own management of affairs fewer occasions for dissension would arise. When the storm arose again, it burst from a quarter where no one would have looked for it.

For the two years following the so-called "Boston Massacre," Hutchinson's administration was comparatively quiet. In the summer of $\mathrm{I} 772$ the excitement again rose to fever heat, over the royal order that the salaries of the judges should henceforth be paid by the crown. This measure, striking directly at the independence of the judiciary, led Samuel Adams to the revolutionary step of organizing the famous Committees of Correspondence. Hutchinson at first underestimated the importance of this step, but presently, taking alarm at the progress which resistance to the government was making, he tried to check it by a sober appeal to reason. In January, I773, he sent a message to the legislature, containing an elaborate and masterly statement of the doctrine of the supremacy of Parliament over the whole British empire. It was a document of prodigious learning and written in excellent temper. Its knowledge of law was worthy of Lord Mansfield, who expressed the warmest admiration for it. It was widely read on both sides of the Atlantic, and Whigs as well as Tories admitted its power. But Hutchinson's great antagonist was equal to the occasion. Never did the acuteness, the strong 
sense, and the dialectic skill of Samuel Adains show to better advantage than in the reply which he drew up for the legislature. Its force was such as to make the governor doubt whether he had done wisely, after all, in opening an argument on the subject. He sent in an elaborate rejoinder, to which Adams again replied, and for some time the controversy was sustained with dignity on both sides. Whatever opinions were held as to the merits of the arguments, the governor certainly gained in personal popularity during the winter, and still more in the spring, when he met the governor of New York at Hartford, and succeeded in adjusting the long-disputed boundary line between New York and Massachusetts, to the entire satisfaction of the latter colony.

This was the last moment of popular favour that Hutchinson was ever to know. The skein of events that were to compass his downfall had already. unwound itself in London. For several years a private and unofficial correspondence had been kept up between Hutchinson and other officers of the crown in Massachusetts, on the one hand, and Thomas Whately, who had formerly been private secretary to George Grenville, on the other. Whately was a friend to America, and disapproved of the king's policy. Besides Hutchinson, the chief writers were his brother-in-law, Andrew Oliver, who was now associated with him as lieutenantgovernor, and Charles Paxton, one of the revenue officers in Boston. In these letters Hutchinson freely commented on the policy of Samuel Adams and other popular leaders as seditious in tendency; he doubted if it were practicable for a colony removed by three thousand miles of ocean to enjoy all the liberties of 
the mother country without severing its connection with her; and he had therefore reluctantly come to the conclusion that Massachusetts must submit to "an abridgment of what are called English liberties." In this there was nothing that he had not said again and again in public, and amply explained in his famous message to the assembly. But Oliver went farther, and urged that judges and other crown officers should have fixed salaries assigned and paid by the crown, so as to become independent of popular favour. Paxton enlarged upon the turbulence of the people of Boston, and thought two or three regiments needful for preserving order. The letters were written independently on different occasions, and the suggestions were doubtless made in perfect good faith. In June, I 772, Thomas Whately died, and all his papers passed into the custody of William, his brother and executor. In the following December, before William Whately had opened or looked over the packet of letters from Massachusetts, it was found that they had been purloined by some person unknown. It is not certain that the letters had ever really passed into William Whately's hands. They may have been left lying in some place where they may have attracted the notice of some curious busybody, who forthwith laid hands upon them. This has never been satisfactorily cleared up. At all events they were carried to Dr. Franklin, as containing political intelligence that might prove important. Franklin was then the agent at the British court, representing Massachusetts, Pennsylvania, New Jersey, and Georgia. The dispute over the salaries of the judges was then raging in Massachusetts. The judges had been threatened with impeachment should 
they dare to receive a penny from the royal treasury, and at their head was Andrew Oliver's younger brother Peter, chief justice of Massachusetts. As agent for the colony, Franklin felt it his duty to give information of the contents of the letters now laid before him. Although they purported to be merely a private correspondence, it appeared to him that they were written by public officers to a person in public station, on public affairs, and intended to procure public measures; their tendency, he thought, was to incense the mother country against her colonies. Franklin was doubtless mistaken in this, but he felt as Walsingham might have felt on suddenly discovering, in private and confidential papers, the clew to some popish plot against the life of Queen Elizabeth. From the person who brought him the letters he got permission to send them to Massachusetts, on condition that they should be shown only to a few people in authority, that they should not be copied or printed, that they should presently be returned, and that the name of the person from whom they were obtained should never be disclosed. This last condition was thoroughly fulfilled. The others must have been felt to be mainly a matter of form; it was obvious that, though they might be literally complied with, their spirit would inevitably be violated. The letters were sent to the proper person, Thomas Cushing, speaker of the Massachusetts assembly, and he showed them to Hancock, Hawley, and the two Adamses. To these gentlemen it could have been no new discovery that Hutchinson and Oliver held such opinions as were expressed in the letters; but the documents seemed to furnish tangible proof of what had long been vaguely sur- 
mised, that the governor and his lieutenant were plotting against the liberties of Massachusetts. They were soon talked about at every town meeting and on every street corner. The assembly twitted Hutchinson with them, and asked for copies of these and other such papers as he might see fit to communicate. $\mathrm{He}$ replied, somewhat sarcastically, "If you desire copies with a view to make them public, the originals are more proper for the purpose than any copies." Mistaken as Hutchinson's policy was, his conscience acquitted him of any treasonable purpose, and he must naturally have preferred to have people judge him by what he had really written, rather than by vague and distorted rumours. His reply was taken as sufficient warrant for printing the letters, and they were soon in the possession of every reader in England or America who could afford sixpence for a political tract. On the other side of the Atlantic they aroused as much excitement as on this, and William Whately became concerned to know who could have stolen the letters. On very slight evidence he charged a Mr. Temple with the theft, and a duel ensued, in which Whately was dangerously wounded. Hearing of this affair, Franklin published a card, in which he avowed his own share in the transaction, and in a measure screened everybody else by drawing the full torrent of wrath and abuse upon himself. All the ill-suppressed spleen of the king's friends was at once discharged upon him.

Meanwhile in Massachusetts the excitement was furious. The autumn of $\mathrm{I} 773$ had arrived, and with it Lord Dartmouth's tea ships, and Hutchinson was brought into an attitude of hostility to the people such 
as he could not have foreseen when he accepted the governorship. It was mainly his stubborn courage that kept the consignees of the tea from resigning their commissions in Boston, as the consignees in New York, Philadelphia, and Charleston had done. This made Boston the battle-ground upon which the tea question was to end in a flat defiance of the British government. Hutchinson tried to avoid the difficulty by advising the consignees to order the vessels on their arrival to anchor below the Castle, so that if it should seem best not to land the tea they might go to sea again. When the first ship arrived, she was anchored accordingly, but it happened that she had other goods on board which some merchants in town were needing, and a committee, headed by Samuel Adams, ordered the captain to bring his ship to dock, in order to land these goods. This brought the vessel within the jurisdiction of the custom-house, and when the officers refused to give her a clearance until she had landed the tea also, there was no way of getting her out to sea without a pass from the governor. But Hutchinson felt that granting a pass for a ship until she had been duly cleared at the custom-house would be a violation of his oath of office. The situation was thus a complete deadlock, and for the popular party there was no way out except in the destruction of the tea.

The antagonism between governor and people, which thus culminated in the first great crisis of the American Revolution, had been immeasurably enhanced by the adroit use which had been made of the Whately letters. One cannot, in this particular, view the conduct of Samuel Adams and his friends with entire approval. 
As Dr. Ellis has well said, it was a case of "the most vehement possible cry with the slightest possible amount of wool." Strong emphasis was laid upon the phrase "abridgment of what are called English liberties," and serious injustice was done by tearing it from its context. Nothing could show this more clearly than the governor's own frank and manly statement: "I differ in my principles from the present leaders of the people. ... I think that by the constitution of the colonies the Parliament has a supreme authority over them. I have nevertheless always been an advocate for as large a power of legislation within each colony as can consist with a supreme control. I have declared against a forcible opposition to the execution of acts of Parliament which have laid taxes on the people of America; I have, notwithstanding, ever wished that such acts might not be made as the Stamp Act in particular. I have done everything in my power that they might be repealed. I do not see how the people in the colonies can enjoy every liberty which the people in England enjoy, because in England every man may be represented in Parliament . . . ; but in the colonies, the people, I conceive, cannot have representatives in Parliament to any advantage. It gives me pain when I think it must be so. I wish also that we may enjoy every privilege of an Englishman which our remote situation will admit of. These are sentiments which I have without reserve declared among my private friends, in my speeches and messages to the General Court, in my correspondence with the ministers of state, and I have published them to the world in my history; and yet I have been declared an enemy and a traitor to my country 
because in my private letters I have discovered the same sentiments, for everything else asserted to be contained in those letters (I mean of mine) unfriendly to the country, I must deny as altogether groundless and false." By this last qualification the governor shows himself aware of the cruel injustice wrought in holding him responsible for everything that Paxton and Oliver had said. The letters, when published together in a single pamphlet, were read as containing from first to last the sentiments of Hutchinson. In the popular excitement the fact that they were not all his letters was lost sight of; and by a wild leap of inference not uncommon in such cases, people soon reached the conclusion that the conduct of the British government for the past ten years had been secretly instigated by him; that he was to blame for the Stamp Act, the sending of troops to Boston, the tea measures, and everything. It was this misunderstanding that heaped upon Hutchinson's name the load of opprobrium which it has had to carry for a hundred years. His mistaken political attitude would not of itself have sufficed to call forth such intense bitterness of feeling. The erroneousness of his policy is even clearer to us than to his contemporaries, for with the lapse of time it has been more and more completely refuted by the unanswerable logic of events. But we can also see how grievously he was misjudged, since we know that he was not the underhanded schemer that men supposed him to be. Never has there been a more memorable illustration of the wrong and suffering that is apt to be wrought in all directions in a period of revolutionary excitement than the fact that during the autumn of 1773 one of the purest and most high- 
minded citizens of Massachusetts was regarded by so many other pure and high-minded citizens as little better than a traitor. Acting upon this belief the assembly, sometime before the crisis of the Tea Party, had already despatched a memorial across the ocean, beseeching his Majesty to remove Governor Hutchinson and Lieutenant-governor Oliver from office.

In January, I774, the petition was laid before the privy council, in the presence of a large and brilliant gathering of spectators. Never before had so many lords been seen in that chamber at one time. The Archbishop of Canterbury was there, and Lord Shelburne, and Edmund Burke; and there, too, were to be seen the illustrious Dr. Priestley and youthful Jeremy Bentham. At the head of the table sat the Lord President Gower, and in the chimney corner stood an old man of eight and sixty, with spectacles and flowing wig, dressed in a suit of dark Manchester velvet. This was Dr. Franklin, to whose part it fell, as agent for the Massachusetts assembly, to present its petition. The news of the Boston Tea Party had just arrived in London, and people's wrath waxed hot against the Americans. The solicitor-general, David Wedderburn, instead of discussing the petition on its merits, broke out with a scurrilous invective against Franklin, whom he accused, if not of actually stealing the Whately letters, at least of basely meddling with private correspondence from the lowest of motives, to get Hutchinson dismissed from office and secure for himself the governorship of Massachusetts. Such a man, said Wedderburn, has forfeited forever the respect of his fellow-creatures, and should never dare 
again to show his face in society, - this man of letters, forsooth! "a man of three letters." At this obvious allusion to the old Roman slang expression preserved in Plautus, where "a man of three letters" is $f-u-r$, a thief, there were loud cries of "Hear, hear!" Of the members of government present, Lord North alone preserved his unfailing decorum; the others laughed and applauded, while Franklin stood as unmoved as the moon at the baying of dogs. His conduct had, perhaps, been hardly defensible, and it had probably worked more harm than good, but his conscience was certainly quite clear; and he could not but despise the snarls of such a cur as Wedderburn, whom the king, while fain to use him as a tool, felt free to call the biggest knave in the realm. Ralph Izard, the hot-blooded South Carolinian, who listened to the insulting speech, afterward declared that if it had been aimed at him, he would have answered on the spot with a challenge. Lord Shelburne wrote to Lord Chatham that the indecency of the affair was such as would have disgraced an ordinary election contest. Before the meeting was adjourned, Wedderburn stepped up to say good-morning to Dr. Priestley; but the great man of science, kindest and most gentle of mortals, indignantly turned his back. Ah, quoth Immanuel Kant, in his study at distant Königsberg, as he smoked his evening pipe and listened to the story, we have heard before how Prometheus, who brought fire from heaven, was teased by an unclean bird. The affair ended as might have been foreseen. The Massachusetts petition was not simply rejected, but condemned as scandalous; and next day Franklin was dismissed from his office of postmaster-general for America. 
Events, however, soon brought about practically Hutchinson's removal. When in April Parliament made up its mind, in retaliation for the Tea Party, to annul the charter of Massachusetts and starve the town of Boston into submission, it was clear that such a man as Hutchinson would not serve the purpose. For such measures of martial law a soldier was likely to be needed, and the work was intrusted to Thomas Gage. This change afforded Hutchinson the opportunity he had for some time desired, of going to England in the hope of doing something toward putting an end to these dreadful quarrels and misunderstandings. Of the retaliatory measures he profoundly disapproved, and could he but meet the king face to face, he hoped that his plea for Massachusetts might prove not ineffectual. When on the morning of the first of June, I 774, he left his charming home in Milton, without the slightest premonition that he was never to see it again, it was in the spirit of a peacemaker that he embarked for England, but there were many who saw in it the flight of a renegade. It was not in a moment, however, that this view prevailed. In spite of all the bitter conflict and misunderstanding that had come to pass, a character so noble as Hutchinson's could not all at once lose its hold upon honest men and women who had known him for years in the numberless little details of life that do not make a figure in political history. The governor's heart was cheered, even if his forebodings were not quieted, by formal addresses from some of the leading townsmen of Milton and Boston, in which his many services to the commonwealth received their full meed of affectionate acknowledgment. But events were now moving fast, and 
relations among men were to be whirled hither and thither as in a cyclone. Most of these addressers were soon to be judged as Tories and condemned to outer darkness. Those of us who remember the four years following 1860, remember how lax men's memories are of some things, how tenacious of others. So the guns of Lexington and Bunker Hill soon left little of Hutchinson's reputation standing, save that which the last two years had brought him. The house at Milton was used as barracks for soldiers; the portrait of its owner, now in the possession of the Massachusetts Historical Society, was slashed and torn by bayonets; all his accessible property was confiscated, and his best coach was sent over to Cambridge for the use of General Washington. Even so late as I774 a little town in the highlands of Worcester County was incorporated under the name of Hutchinson, but two years later, on its earnest petition, the legislature allowed it to call itself after the eloquent Colonel Barré, who had in Parliament so warmly defended the Americans. Hutchinson Street in Boston, leading down to the wharf which had witnessed the smashing of the teachests, was rechristened as Pearl Street. Even the school in Bennet Street lost the name of its founder, and is known to-day as the Eliot school.

No sooner had Hutchinson arrived at his hotel in London, than Lord Dartmouth came for him and hurried him off to an interview with the king, without waiting for him to change his clothes. The conversation, as preserved in the diary, is interesting to read. Neither king, minister, nor governor had the faintest glimmer of prevision as to the course which events were about to take. Hutchinson was right, however, 
in feeling uneasy about the vindictive acts of April, and expressed, in guarded but emphatic terms, his disapproval of them and his wish that they might be repealed; but the king and Dartmouth felt sure that Gage would soon mend matters so that there would be no need for further harshness, and it was intended that Hutchinson should presently return to Boston and resume the office of governor. The king did not regard him as superseded by Gage, and it is accordingly right to call Thomas Hutchinson the last royal governor of Massachusetts. A few weeks later the king offered him a baronetcy, which he refused. He cared little for such honours or emoluments as England could give him. His heart was in Massachusetts. Better a farmhouse there, he said, than the finest palace in the Old World. Life in London was, nevertheless, made pleasant for him by the society of the most cultivated and interesting people, and he was everywhere treated with the highest consideration. He now devoted his working hours to the third volume of his history, covering the period from I 750 to $I 774$. This was, from the nature of the case, largely a narrative of personal experience, and in view of what that experience had been, its fairness and good temper are simply astonishing. The volume remained in manuscript until 1828 , when it was published in London by one of the author's grandsons. His diary and letters covering the period of his life in London have been published in two volumes by a great-grandson, since 1884 , and amply confirm the most favourable view that can be taken of his character and motives. These documents give a most entertaining view of the state of opinion in London, as the fragmentary tidings of the war found 
their way across the ocean, and they throw much light upon the history of the whole situation. The writer's intense love for New England is mournfully conspicuous from first to last. Until Burgoyne's surrender he cherished the hope of returning thither, but after that event he resigned himself to the probability that he must die in exile. The deaths of two of his five children took from his fast-diminishing strength. On the $3 \mathrm{~d}$ of June, 1780 , as he was getting into his carriage at Brompton, there came a stroke of apoplexy, and he fell back into the arms of his servant. His funeral procession passed by the smouldering wrecks of houses just burned in those hideous Gordon riots that Dickens has immortalized in "Barnaby Rudge."

For intellectual gifts and accomplishments, Hutchinson stands far above all the other colonial governors and in the foremost rank among American public men of whatever age. For thorough grasp of finance, he was the peer of Hamilton and Gallatin. In I809 John Adams, who loved him not, said "he understood the subject of coin and commerce better than any man I ever knew in this country." His mastery of law was equally remarkable, and as a historian his accuracy is of the highest order. His personal magnetism was so great that in spite of all vicissitudes of popular feeling, so long as he remained upon the scene, and until after his departure for England had been followed by the outbreak of war, he did not fully lose his hold upon the people. He was nothing if not public-spirited, and his kindness toward persons in distress and sorrow knew no bounds. Yet in intellectual sympathy with plain common people he seems to have been deficient. He was too thoroughly an aristocrat to enter into their 
ways of thinking; and herein was one source of his weakness as a statesman. But the chief source of that weakness, as is so often the case, was closely related to one of his most remarkable features of strength. That inborn legal quality of his mind which, without the customary technical training, made him a jurist capable of winning the admiration of Lord Mansfield, was too strongly developed. Allied with his rigid Puritan conscience, it outweighed other good qualities and warped his nature. He was enveloped in a crust of intense legality, through which he could not break. If he had lived a century later, he might have written the memorable pamphlet in which another great Massachusetts jurist, Benjamin Curtis, argued that President Lincoln had no constitutional authority for emancipating the slaves. It is always well that such strides in advance should be made under careful protest, for only thus is society kept secure against crude experiments. But the men best fitted to utter the protest are not likely to be competent leaders in revolutionary times, when it becomes necessary to view many facts in a new light. For this is required the rare tact of a Samuel Adams or a Lincoln. It was Hutchinson's misfortune that, with such a rigidly legal temperament, he should have been called to fill a supreme executive office at the moment of a great revolutionary crisis. Nothing but failure and obloquy could come from such a situation. Yet the pages of history are strewn with examples of brave men slain in defence of unworthy causes, and because they have been true to their convictions we honour and respect them. Never did Hutchinson flinch a hair's-breadth for the sake of personal advancement. Would that there were more 
LAST ROYAL GOVERNOR OF MASSACHUSETTS 5 I

of this disinterested courage among our public men to-day! When we listen to the cowardly talk of candidates who use language to conceal thought, and dare not speak out like men for fear of losing votes, it occurs to us sometimes that in the life of nations there is no danger so great as the loss of true manliness; and we cannot but feel that from the stormy career of this old Tory governor-maligned, misunderstood, and exiled, but never once robbed of selfrespect - there is still a lesson to be learned. 



\section{II}

CHARLES LEE

THE SOLDIER OF FORTUNE 



\section{CHARLES LEE}

\section{THE SOLDIER OF FORTUNE}

Whenever a great war is going on, it is apt to draw from other countries a crowd of officers who come to look on and give advice, or perhaps to study the art of war under new conditions, or to carve out for themselves a career for which no chance seems to be offered them at home. This was amply illustrated in the American War of Independence. The war was watched with interest in Europe, not from any special regard for the Americans, - about whom people in general knew rather less than they knew about the inhabitants of Dahomey or of Kamtchatka, - but from a belief that the result would seriously affect the position of Great Britain as a European power. A swarm of officers crossed the Atlantic in the hope of obtaining commands, and not less than twenty-seven such foreigners served in the Continental army, with the rank of general, either major or brigadier. I do not refer to such French allies as came with Rochambeau, or in company with the fleets of D'Estaing and De Grasse. I refer only to such men as obtained commissions from Congress and were classed for the time as American officers. For the most part these men came in the earlier stages of the war, before the French alliance had borne fruit. Some were drawn hither by a noble, disinterested enthusiasm for the cause of political lib- 
erty; some were mere selfish schemers, or crackbrained vagrants in quest of adventure. Among the latter one of the most conspicuous was Thomas Conway. Among the former there were five who attained real eminence, and have left a shining mark upon the pages of history. These were De Kalb and Pulaski, who gave up their lives on the battle-field; Lafayette and Kosciuszko, who afterwards returned to their own countries to play honourable but unsuccessful parts; and, last not least, the noble Steuben, who died an American citizen in the second term of Washington's presidency.

But in the eyes of the generation which witnessed the beginning of the Revolutionary War, none of the European officers just mentioned was anything like so conspicuous or so interesting a figure as the man to whose career I invite your attention this evening; Charles Lee was on the ground here before any of these others; he had already been in America; he came with the greatest possible amount of noise; he laid claim to the character of a disinterested enthusiast so vehemently that people believed him. For a while he seemed completely identified with the American cause; and as his name happens to be the same as that of an illustrious Virginian family, posterity seems to have been in some danger of forgetting that he was not himself an American. I don't know how many times I have been asked to state his relationship to the Lees of Virginia; and, what is worse, I found in print some time ago, in a history of the town of Greenwich, R.I., the statement that the traitor of Monmouth was father of the great general, Robert Edward Lee, who might thus be supposed to have inherited what the 
writer is pleased to consider his natural propensity toward treason! ${ }^{1}$ Such absurdities show that even the industrious writers of town histories do not always consult biographical dictionaries and other easily accessible sources of information, but it is a pity that they should find their way into print. Whether the Cheshire family to which Charles Lee belonged was in any remote way connected with the Lees of Virginia is uncertain. Of Charles Lee's immediate ancestry little is known except that he was the youngest son of John Lee, of Dernhall in Cheshire, and Isabella, daughter of Sir Henry Bunbury, of Stanney in the same county. John Lee was for some time captain of dragoons, and at length, after I 742, colonel of the 44th regiment of infantry. Charles Lee was born at Dernhall in $\mathrm{I} 73 \mathrm{I}$, and is said to have received a commission in the army at the age of eleven. This seems at first a ridiculous story; but that was an age of abuses, and a study of the British army list in the good old days of the two first Georges brings to light some astonishing facts. Ensigns and cornets were duly enrolled, and drew their quarterly stipends, before leaving the nursery; and the Duchess of Marlborough, in one of her letters, has something still better to tell. Colonel Lepel made his own daughter a cornet in his regiment as soon as she was born; and why not? asks the duchess; at that time of life a girl was quite as useful to the army as a boy. This girl was afterward Lady Hervey, and she went on drawing her salary as

1 "Charles Lee died a miserable, neglected, and disappointed man. It would seem that treason is hereditary, as his son, the late General Lee, commander-in-chief of the Southern Rebellion (sic), followed in the footsteps of his father." - D. H. Greene's "History of East Greenwich, R.I.," p. 259. 
cornet for some years after she had become maid of honour to the queen. By and by it occurred to Lord Sunderland that this was a little too absurd; and so he induced her to resign her commission in exchange for a pension from George I. ${ }^{1}$ This memorable incident seems to have escaped the notice of our modern framers of pension bills.

As the date at which Charles Lee reached the age of eleven was precisely that at which his father reached the rank of colonel, it is not improbable that he may have received a commission of the sort just described. However this may have been, he is known to have studied at the free grammar-school of Bury St. Edmunds, in Suffolk, and afterward at an academy in Switzerland. $\mathrm{He}$ acquired some familiarity with Greek and Latin, and a thorough practical knowledge of French. In later years, in the course of his rambles about Europe, he became more or less proficient in Spanish, Italian, and German. From an early age he seems to have applied himself diligently to the study of the military art. In May, I 75 I, shortly after his father's death, he received a lieutenant's commission in that $44^{\text {th }}$ regiment, of which his father had been colonel. The regiment was ordered to America in I754, and under its lieutenant-colonel, Thomas Gage, formed the advance of Braddock's army, and received the first attack of the French and Indians in the terrible battle of the Monongahela. It was in this disastrous campaign that Lee must have become acquainted with Horatio Gates and perhaps with George Washington. The remains of the shattered army were in the autumn taken northward to

${ }^{1}$ G. H. Moore, "Treason of Charles Lee," p. 5. 
Albany and Schenectady, where they went into winter quarters. Lee was present at several conferences between Sir William Johnson and the chiefs of the Six Nations, and became much interested in the Indians. His relations with them soon became so. friendly that he was adopted into the Mohawk tribe of the Bear, and thus acquired the privilege of smoking a pipe with them as they sat around the council fire. $\mathrm{He}$ also formed a temporary matrimonial alliance with one of the foremost families of the Six Nations, and wrote about it to his sister in England, with quaint frankness. "My wife," said he, "is daughter to the famous White Thunder who is Belt of Wampum to the Senakas - which is in fact their Lord Treasurer. She is a very great beauty, and is more like your friend Mrs. Griffith than anybody I know. I shall say nothing of her accomplishments, for you must be certain that a woman of her fashion cannot be without many." The Indians, he continues, are even more polite than the French, "if you will allow good breeding to consist in a constant desire to do everything that will please you, and a strict carefulness not to say or do anything that may offend you." Of this well-bred desire to please, the same letter gives an instance. ${ }^{1}$ A young Mohawk, anxious to show his gratitude for some trifling service Lee had rendered him, prowled about the neighbouring woods until he succeeded in killing a French sergeant on picket duty; then he carefully decorated the scalp with bright blue ribbons and presented it to Lee in token of brotherly love. Lee's definition of good breeding is excellent; but his practice did not comport with his theory. He was

${ }^{1}$ New York Historical Society Collections, Lee Papers, I. 5. 
already noted among his fellow-soldiers for an arrogant and quarrelsome temper, and the significant name bestowed upon him by his Mohawk friends was "Boiling Water." He seemed to court opportunities for saying and doing offensive things. His tongue bit shrewdly; it was a nipping and an eager tongue. He was fond of commenting upon the imbecility of his superior officers, and the conduct of the war afforded plenty of occasions for this display of humour. About this time - in accordance with a practice which survived in the British army until Mr. Gladstone put an end to it - he purchased, for $£ 900$, a captain's commission in the 44th. The commission was dated June II, I756. The regiment did little that year except take part in a futile attempt to raise the siege of Oswego, which surrendered to the French on the I 4 th of August. After another idle winter in the neighbourhood of Albany, the troops were conveyed by sea to Halifax, from which point the Earl of Loudon intended to pounce upon the great stronghold of Louisburg. A powerful force was collected, and some acres were prudently planted with succulent vegetables as a safeguard against scurvy; but nothing more was accomplished, for the commander-in-chief, according to Franklin, resembled King George on the tavern sign-boards, always on horseback but never getting ahead. When Captain Lee openly derided the campaign as a "cabbage-planting enterprise," the remark drew public attention to the young man, and no doubt there were quarters where it sank deep and was remembered against him.

Early in the next summer, $175^{8}$, we find the $44^{\text {th }}$ regiment marching up the valley of the Hudson, as 
part of the fine army with which General Abercrombie was expected to take Ticonderoga. At the Flats near Albany, Lee's company encamped on the farm of Mrs. Schuyler, aunt of the distinguished general of that name, a noble and benevolent woman, of whom Mrs. Grant of Laggan has left such a charming description, in her "Memoirs of an American Lady." Mrs. Schuyler's generosity toward soldiers was well known; but Lee, who had forgotten to provide himself with the proper certificates for obtaining supplies, and was seizing horses and oxen, blankets and eatables, to right and left, with as little ceremony as if in an enemy's country, did not spare this lady's well-stocked farm; and when she ventured a few mild words of expostulation, he replied with such a torrent of foul epithet that she had much ado to restrain her servants from assaulting him. A few days later came the murderous battle before Ticonderoga, where British and Americans were so terribly defeated by Montcalm. There Thomas Gage fought side by side with Israel Putnam and John Stark, little dreaming of another bright summer day near Boston, seventeen years to come; there was slain Lord Howe, eldest of the three famous brothers; and there in a gallant charge our cynical young captain was shot through the body and carried off from the field. Bruised and battered, and with two ribs broken, he doubtless had breath enough left to growl and snarl over the incompetency of the general whom, in the next letter to his sister, he calls "beastly poltroon" and "booby-inchief." On hearing the news, Mrs. Schuyler had her largest barn prepared for a hospital. Thither, with many others, Captain Lee was taken and treated so 
kindly that his rough heart was softened. He averred, with terrific oaths, that "a place would surely be reserved for Madame in heaven, though no other woman should be there, and that he should wish for nothing better than to share her final destiny." ${ }^{1}$

By December the wound had healed, and we find him in winter quarters on Long Island, thrashing the surgeon of his regiment for a scandalous lampoon. And here we are introduced to the first of a series of little "special providences" keeping this personage alive for the singular part which he was to play in American history. The cowardly doctor nursed his wrath, lurked among the bushes by a lonely roadside, seized the captain's bridle, and fired at his heart; but the horse opportunely shied and the bullet tore Lee's clothing and skin just under the left arm. The surgeon was cocking a second pistol when another officer came up and struck it from his hand. Then the surgeon was collared and dragged off to camp, where a court-martial presently turned him adrift upon the world.

The next summer Lee was present at the capture of Fort Niagara, and was sent with a small party to follow the route of the few French who escaped. This was the first party of English troops that ever crossed Lake Erie. Their march led them to Fort Duquesne (now Pittsburg), which General Forbes had captured the year before. Thence a march of seven hundred miles brought them to Crown Point to meet General Amherst. There was yet another long march to Oswego and back before Lee settled down for the winter in Philadelphia, and was employed in beating

${ }^{1}$ Lossing's "Schuyler," I. 154. 
up recruits. In the final campaign of 1760 his regiment was part of the force led by Amherst from Lake Ontario down the St. Lawrence to Montreal; and after the capture of that town had completed the conquest of Canada, he returned to England. His uncle, Sir William Bunbury, writing from London, had alluded to chances of promotion, and incidentally observed that many fashionable matches were reported, and he had better come home before all the fine young ladies were disposed of. Perhaps Sir William had not heard of the accomplished daughter of the "Lord Treasurer" White Thunder. The promotion came in August, I 76I, when Lee was appointed Major in the rozd regiment, known as the Volunteer Hunters. War was then breaking out between Spain and Portugal, and in 1762 a small British army was sent to aid the Portuguese. The chief command of the allied forces was given to one of the ablest generals of his time, the famous Count von Lippe-Schaumburg, a grandson of King George I., and own cousin to the brothers Howe. Lee accompanied the expedition with a brevet of lieutenant-colonel from the king of Portugal, and his brigadier-commander was General Burgoyne. The campaign was a brilliant success, and Lee received honourable mention for the masterly way in which he surprised and carried by storm the Spanish position at Villa Velha on the Tagus. On his return to England he busied himself with schemes of colonization in America, in which he aspired to emulate the fame of Penn and Oglethorpe. A colony was to be founded on the Ohio River below the Wabash, and another on the Illinois. Inducements were to be held out for Protestant emigrants from Switzerland 
and Germany, as well as from England; but the enterprise found few supporters. About this time, in 1763, the 1o3d regiment was disbanded, and Lee passed virtually into retirement as a major on half-pay. At this he was disappointed and enraged, for a good word from the Count von Lippe-Schaumburg had given him some reason to expect promotion. But the ministry disliked him, partly on account of his liberal opinions and the vehemence with which he declared them, partly because of the fierceness with which he vilified and lampooned anybody of whom he disapproved. Though his later career showed that he had not the courage of his convictions, yet there can be no doubt that he really entertained very decided opinions. $\mathrm{He}$ was a radical free-thinker of the unripe, acrid sort, like his contemporaries, John Wilkes and Thomas Paine. He wrote and talked quite sensibly about many things; his sympathetic appreciation of Beccaria's great treatise on "Crime and Punishment" was much to his credit; as a schoolboy in Switzerland he had learned republican theories under good teachers; and there is no reason for doubting his sincerity in hating and despising the despotism which then prevailed almost everywhere on the continent of Europe. Sometimes he dealt humorously with such topics; as in his epistle to David Hume. In reading books on history, he said, nothing had so frequently shocked him as the disrespectful and irreverent manner in which divers writers have spoken of crowned heads. "Many princes, it must be owned, have acted in some instances not altogether as we could wish," but it is the duty of the historian to draw, a veil over their weakness. He was glad to see that Mr. Hume had 
acted upon this sound precept in depicting the exalted virtues of the Stuarts. He had heard that this history of England was the only one his sacred Majesty George III. could be induced to read, and he didn't wonder at it. He had often thought of writing history himself, and now that he had got his cue from Mr. Hume, he should go on and devote his energies to the much-needed task of rescuing from unmerited odium those grossly slandered saints, the emperor Claudius and his successor Nero.

But it was seldom that Lee's sarcasm was so gentle as this. Usually he lost his temper and hurled about such epithets as scoundrels, idiots, numskulls, diabolical tyrants, damned conspirators, sceptred robbers, impious cutthroats. Was it a public man of whom he disapproved, he would say "everything he touches becomes putrid;" was it some opinion from which he dissented, he would say "it was the most cunning fiend in hell who first broached this doctrine." 1 Speech less peppery than this seemed tasteless to Charles Lee. The accumulation of oaths and superlatives often makes the reading of his letters and pamphlets rather dreary work. When they were first published, or quoted in conversation, they served to offend powerful people and ruin the writer's hopes of advancement. Had he been a man of real ability, or had he been favoured by some queer freak of fortune that would have made him, like Wilkes, a bone of contention, he might have risen to eminence in the opposition party. But his talents were too slender for this; something more than growling and swearing was needed. Accordingly he soon made up his mind

${ }^{1}$ New York Historical Society Collections, Lee Papers, I. 74. 
that he was not properly appreciated in England, and early in 1765 he made his way to that home of turbulent spirits, Poland, where he received an appointment on the staff of the new king, Stanislaus Augustus. Next year, in accompanying the Polish embassy to Turkey, he narrowly escaped freezing to death on the Balkan Mountains, and again, while in Constantinople, came near being buried in the ruins of his house, which was destroyed by an earthquake. In 1766 he returned to England and spent two years in a fruitless attempt to obtain promotion. Having at length quite established his reputation as a disappointed and vindictive place-hunter, he tried Poland again. In I 769 he was commissioned major-general in the Polish army, but did not relinquish his half-pay as a British major, because it was "too considerable a sum to throw away wantonly." ${ }^{1}$ Early in the winter he served in a campaign against the Turks, and was present in a battle at Chotzim on the Moldavian frontier. Here, as usual, he declared that the commanders under whom he served were fools. ${ }^{2}$ His brief service was ended by a fever from which he barely escaped with his life. The rest of the winter was spent in Vienna, and in the spring of $\mathrm{I} 770$ he proceeded to Italy, where he lost two fingers in an affair of honour in which an Italian officer crossed swords with him. His earliest biographer, Edward Langworthy, observes that "his warmth of temper drew him into many rencounters of this kind; in all which he acquitted himself with singular courage, sprightliness of imagination, and great presence of mind." ${ }^{\circ}$

1 Moore, p. I 5.

${ }^{2}$ Lee Papers, I. 89.

${ }^{8}$ Langworthy, "Memoirs of Charles Lee," London, I792, p. 8. 
What in the world sprightliness of imagination in duelling may be, we are left to conjecture. Perhaps in this case it may have been exemplified in the immediate recourse to pistols, the result of which was that the Italian was slain, and Lee was obliged to flee to Gibraltar, where he embarked for London. In May, I772, he was promoted to the rank of lieutenantcolonel on half-pay, but was unable to obtain any further recognition from government.

Ever since the Stamp Act our knight-errant had kept an eye upon the troubles in America, and his letters show that by soldiers and princes at least, even as far as Poland, the quarrel between Great Britain and her colonies was watched with interest. It now seems to have occurred to him that America might afford a promising career for a soldier of fortune. He arrived in New York on the Ioth of November, I 773, in the midst of the agitation over the tea ships, and the next ten months were spent in a journey through the colonies as far as Virginia in one direction and Massachusetts in the other. In the course of this journey he made the acquaintance of nearly all the leaders of the Revolutionary party, and won high favour from the zeal with which he espoused their cause. He visited Mount Vernon and was warmly greeted by Washington. Whether Washington remembered him or not, as a lieutenant in $\mathrm{I} 755$, is not at all clear. But now the great European soldier, who had fought on the banks of the Tagus and of the Dniester, and was a member of the liberal party in England withal, was sure to interest the noble, genial, and modest man who commanded the militia of Virginia. Whether he could have found favour with Mrs. Washington is 
much more doubtful. With ladies Lee was never a favourite. Mercy Warren, the sister of James Otis, and one of the brightest and most highly cultivated women of her time, saw Lee under all the glamour of his newly assumed greatness, yet, while she admitted that he was "judicious" and "learned" (these were her words), she could not but remark upon his extreme coarseness and his slovenly habits. Indeed, when we observe the frightful latitude of speech in some of his letters, we feel that he would have been an uncomfortable guest to invite to dinner. $\mathrm{He}$ was tall and extremely slender, almost without shoulders, the forehead rather high but very narrow, the nose aquiline and enormous, the complexion sallow, the eyes small and deep-set, inquisitive and restless, the upper lip curled in chronic disdain of everything and everybody, the chin contracted and feeble; such was Charles Lee at the age of two and forty, when he revisited America, a weak, dyspeptic, querulous man. His linen, like Daniel Quilp's, was of a peculiar hue, for such was his taste and fancy; his clothes had the air of having been only half put on; and he was seldom seen in private or in public without five or six dogs at his heels. Once he is said to have invited a friend to dinner, and when the meal was served the only other guests were found to be half a score of dogs, both great and small, which squatted on chairs and lapped up their food from plates set before them on the table. "I must have some object to embrace," said he; "when I can be convinced that men are as worthy objects as dogs, I shall transfer my benevolence, and become as stanch a philanthropist as the canting Addison affected to be." 
All these uncouth looks and ways were at first interpreted by the people as eccentricities of genius. To some persons, doubtless, they seemed to add a touch of romantic interest to a man whom every one looked upon as a public benefactor. There is no doubt that at this time he did render some real services with tongue and pen, while his self-seeking motives were hidden by the earnestness of his arguments in behalf of political liberty and the unquestionable sincerity of his invectives against the British government. The best of his writings at this time was the "Strictures on a Friendly Address to all Reasonable Americans, in Reply to Dr. Myles Cooper," in which the arguments of the Tory president of King's College were severely handled. This pamphlet, published in I 774 , was many times reprinted, and exerted considerable influence. While the first Continental Congress was in session at Philadelphia, Lee was present in that city and was ready with his advice and opinions. He set himself up for an expert in military matters, and there was not a campaign in ancient or modern history which he could not expound and criticise with the air of a man who had exhausted the subject. The American leaders, ill acquainted with military science, and flattered by the prospect of securing the aid of a great European soldier, were naturally ready to take him at his own valuation; but he felt that one grave obstacle stood in the way of his appointment to the chief command. In a letter to Edmund Burke, dated the I6th of December, I774, he observed that he did not think the Americans "would or ought to confide in a man, let his qualifications be ever so great, who has no property among them." To remove this objection he purchased, for 
about $£ 5000$ in Virginia currency (equal to about $£ 3000$ sterling), an estate in Berkeley County, in the Shenandoah valley, near that of his friend Horatio Gates. He did not complete this purchase till the last of May, 1775, while the second Continental Congress was in session. A letter to Gates at this time seems to indicate that he was awaiting the action of the Congress, and did not finally commit himself to the purchase until virtually sure of a high military command. To pay for the estate he borrowed $£ 3000$ of Robert Morris, to whom he mortgaged the property as security, while he drew bills on his attorney in England for the amount. On the 1 7 th of June he received as high a command as Congress thought it prudent to give him, that of second major-general in the Continental army. The reasons for making Washington commander-in-chief were generally convincing. It was as yet only the four New England states that had actually taken up arms, and in order to swell the rebellion to continental dimensions it was indispensable that Virginia should commit herself irrevocably in the struggle. For this reason John Adams was foremost in urging the appointment of Washington as commander-in-chief. But as the only Continental army at that moment existing was the force of sixteen thousand New England men with which General Artemas Ward was besieging Boston, it was not deemed polite to place a second in command over Ward. Some of Lee's friends, and in particular Thomas Mifflin, afterward active in the Conway cabal, urged that he should at least have the first place after Washington; but John Adams declared that, while the New England army would cheerfully serve under Washington, it could not 
be expected to acquiesce in having another than its own general in the next place. Accordingly Ward was appointed first of the major-generals and Lee second. The British adventurer, who had cherished hopes of receiving the chief command, was keenly disappointed. For the present he repressed his spleen against Washington, but made no secret of his contempt for Ward, whom he described as "a fat old gentleman who had been a popular churchwarden, but had no acquaintance whatever with military affairs." When Lee was informed of his appointment, he begged leave, before accepting it, to confer with a committee of Congress with regard to his private affairs. The committee being immediately appointed, he made it a condition of his entering the American service that he should be indemnified by Congress for any pecuniary loss he might suffer by so doing, and that this reimbursement should be made as soon as the amount of such loss should be ascertained. Congress at once assented to this condition, and Lee accepted his appointment. Up to this moment he had retained his commission as lieutenant-colonel in the British army. Three days after obtaining definite promise from Congress, he wrote to Lord Barrington, the secretary of war, in the following characteristic vein:-

"My Lord: Although I can by no means subscribe to the opinion of divers people in the world, that an officer on half-pay is to be considered in the service, yet I think it a point of delicacy to pay a deference to this opinion, erroneous and absurd as it is. I therefore apprise your lordship, in the most public and solemn manner, that I do renounce my half-pay from the date hereof. At the same time I beg leave to 
assure your lordship that whenever it may please his Majesty to call me forth to any honourable service against the natural hereditary enemies of our country, or in defence of his just rights and dignity, no man will obey the righteous summons with more zeal and alacrity than myself; but the present measures seem to me so absolutely subversive of the rights and liberties of every individual subject, so destructive to the whole empire at large, and ultimately so ruinous to his Majesty's own person, dignity, and family, that I think myself obliged in conscience, as a citizen, Englishman, and soldier of a free state, to exert my utmost to defeat them. I most devoutly pray to Almighty God to direct his Majestyinto measures more consonant to his interest and honour, and more conducive to the happiness and glory of his people." ${ }^{1}$

That Lee should have felt called upon to refuse further pay from the crown at the moment of accepting a commission from a revolutionary body engaged in maintaining armed resistance to the crown and its officers, one would think but natural. That in so doing he should have declared himself to be acting in deference to an absurd and overstrained notion of delicacy, shows how far from overstrained his own sense of delicacy was. His letter ${ }^{2}$ is an unconscious confession that he ought long ago to have resigned his half-pay. Now he was simply making a merit of necessity; for there could be little doubt that, as soon as the news of his American commission should reach the ears of the ministry, his half-pay would be cut off,

1 Lee Papers, I. I86.

2 Found in February, 1858, in Sutton Court, Somerset, home of Sir Edward Strachey, where he kept many documents. 
and his other sources of income, amounting in all to about $£$ iooo yearly, confiscated. It was right that he should be indemnified for the loss, and Congress did not for a moment call in question the reasonableness of his request. Nevertheless, when we remember how Lee was afterward fond of prating about his rare disinterestedness and the sacrifices he had made in the cause of American freedom, when we consider especially how he liked to bring himself into comparison with Washington, to the disadvantage of the latter, we cannot help feeling the strong contrast between all this careful bargaining and the conduct of the highminded man who, at that same moment, in accepting the chief command of the Revolutionary army, refused to take a penny for his services.

To this matter of Lee's indemnification our attention will again be directed. Meanwhile, having thus entered the American service, the soldier of fortune accompanied Washington in his journey to Cambridge, and at every town through which they passed he seemed to be quite as much an object of curiosity and admiration as the commander-in-chief. According to Lee's own theory of the relationship between the two, his was the controlling mind. He was the trained and scientific European soldier to whose care had been in a measure intrusted this raw American general, who for political reasons had been placed in command over him. In point of fact, Lee's military experience, as we have here passed it in review, had been scarcely more extensive than Washington's; and of actual responsibility he had wielded much less. Such little reputation as he had in Europe was not that of a soldier, but of a caustic pamphleteer. Yet if 
he had been the hero of a dozen great battles, if he had rescued Portugal from the Spaniard and Poland from the Turk, he could not have claimed or obtained more deference in this country than he did. And no one treated him with higher consideration, or showed more respect for his opinions, than the grand and modest hero, all unconscious of his own Titanic powers, who rode beside him.

On arriving at Cambridge, Lee was placed in command of the left wing of the army, with his headquarters at Winter Hill, in what is now Somerville. The only incident that marked his stay at Cambridge was a correspondence with his old friend Burgoyne, then lately arrived in Boston, which led to a scheme for a conference between Lee and Burgoyne, with a view to the restoration of an amicable understanding between the colonies and the mother country. The proposal came from Burgoyne, and Lee treated it with frankness and discretion. He laid the matter before the Provincial Congress of Massachusetts, and when that body mildly signified its disapproval but left it for Lee to decide, he sent a polite note to Burgoyne declining the interview. This was in July. Four months afterward there came from the Old World a warning that Lee was not a man of trustworthy character. A provisional government had then been formed in Massachusetts with the president of the council for its executive head, and James Otis, in one of the last of his lucid intervals, then occupied that position. On the I 4 th of November Otis sent a letter to Lee, quite touching for its high-minded simplicity. The council had come into possession of a letter from Ireland, making very unfavourable mention of Lee. 
It produced no impression upon the council. On the contrary, says Otis, "we are at a loss to know which is the highest evidence of your virtues - the greatness and number of your friends, or the malice and envy of your foes." ${ }^{1}$ Good advice is often taken in this way. A century has passed without giving us any further clew to this letter.

In December it was learned that Sir Henry Clinton was about to start from Boston on an expedition to the southward, and fears were entertained for Rhode Island and New York. Washington accordingly sent Lee to meet the emergency. After stopping at Newport long enough to arrest a few Tory citizens, Lee proceeded in January to New York, where he did good service in beginning the fortifications needed for the city and neighbouring strategic points. On the news of Montgomery's death, he was appointed to command the army in Canada; but scarcely had he been informed of this appointment when his destination was changed. On the Igth of February, John Adams wrote him, "We want you at New York, we want you at Cambridge, we want you in Virginia, but Canada seems of more importance than any of these places, and therefore you are sent there. I wish you as many laurels as Wolfe and Montgomery reaped there, with a happier fate." From such expressions one may infer that, while Adams had for political reasons urged the appointment of Washington to the chief command of the army, he still placed his main reliance upon the presumed military talents of Lee. At any rate there can be little doubt that the adventurer himself so interpreted them. On the same day a letter

${ }^{1}$ Lee Papers, I. 218. 
from Franklin said, "I rejoice that you are going to Canada "; and another from Benjamin Rush observed, "I tremble only at the price of victory ... . ; should your blood mingle with the blood of Wolfe, Montcalm, and Montgomery, posterity will execrate the Plains of Abraham to the end of time." But on the $3 \mathrm{~d}$ of March Lee wrote to Washington: "My destination is altered. Instead of going to Canada, I am appointed to command to the southward. . . . As I am the only general officer on the continent who can speak and think in French, I confess it would have been more prudent to have sent me to Canada, but I shall obey with alacrity." The reason for this change was the discovery that Clinton's expedition was aimed at some point in the Southern states. Its effect upon Lee's fortunes was much more favourable than he supposed. In Canada, even if he had possessed all the genius for which people gave him credit, he could never have held his ground against Carleton's fine army, outnumbering him four to one; at the South, on the other hand, circumstances played into his hands and enabled him very cheaply to increase his reputation. He went first to Virginia, where he stayed till the middle of May, with headquarters at Williamsburg. The burning political question that spring was whether the colonies should unite in a declaration of independence, and on this point Lee expressed himself with his customary emphasis. To Edward Rutledge he wrote, "By the eternal God! if you don't declare yourselves independent, you deserve to be slaves." At the hesitating action of the Maryland convention in March he lost all patience. "What!" he cried, "when an execrable

${ }^{1}$ Lee Papers, I. 312-3I4; 343. 
tyrant, an abandoned parliament, and a corrupt, pusillanimous people have formed a hellish league to rob you of everything men hold most dear; is it possible there should be creatures who march on two legs and call themselves human, who can be so destitute of sentiment, courage, and feeling, as sobbingly to protest they shall consider separation from these butchers and robbers as the last of misfortunes? Oh, I could brain you with your ladies' fans!" 1 We shall do well to remember this fervid vehemence when we come to the very different key in which the writer's sentiments are pitched just twelve months later.

While these things were going on, Clinton was cruising about Albemarle Sound, but late in May Sir Peter Parker's fleet arrived, with fresh troops under Lord Cornwallis, and presently on the $4^{\text {th }}$ of June the whole armada was collected before the entrance to Charleston harbour. Lee, following by land, reached the city on the same day. Preparations had already been made to resist the enemy, and Colonel William Moultrie was constructing his famous palmetto fort on Sullivan's Island. Lee blustered and found fault, as usual, sneered at the palmetto stronghold, and would have ordered Moultrie to abandon it; but President Rutledge persuaded him to let the sagacious colonel have his way. In the battle which ensued, on the 28th of June, between the fort and the fleet, Moultrie won a decisive and very brilliant victory. But as Moultrie was as yet unknown outside of South Carolina, the credit was by most people inconsiderately given to Lee. In his despatch to Congress the latter spoke generously of the courage and skill of his

1 Langworthy's "Memoirs," p. 382. 
subordinate officer. Perhaps it was hardly to be expected of him that he should frankly confess that the victory was won through neglect of his own scientific advice. On the departure of the discomfited British fleet, the "hero of Charleston," as he was now called, prepared to invade Florida; but early in September he was ordered to report to Congress at Philadelphia. The question of his indemnification had been laid before Congress in a letter from Mr. Rutledge, dated the $4^{\text {th }}$ of July, and action was now taken upon it. The bills for $£ 3000$ drawn upon his agent in England to repay the sum advanced by Robert Morris for the purchase of the Virginia estate had been protested for lack of funds, as Lee's property in England had been sequestrated. Congress accordingly voted, on the 7 th of October, to advance $\$ 30,000$ to General Lee by way of indemnification. Should his English estate ever be recovered, he was to repay this sum.

This point having been made, he went on to New York, where he arrived on the I 4 th of October, and took command of the right wing of Washington's army upon Harlem Heights. By the resignation of General Ward in the spring, Lee had become senior majorgeneral, and in the event of disaster to Washington he might hope at length to realize his wishes and become commander-in-chief. The calamitous fall of Fort Washington, on the r6th of November, seemed to afford the desired opportunity. At that moment Washington, whose defensive campaign had from the outset been marked in every particular by most consummate skill, had placed half of his army on the New Jersey side of the river, in order to check any movement of the British toward Philadelphia. He had left 
Lee at Northcastle, with the other half of the army, about seven thousand men, with instructions to await his orders and move promptly upon receiving them. As soon as it had become evident that Howe was about to throw a superior force against Washington, the latter sent an order to Lee to cross the Hudson River without a moment's delay, and effect a junction of the two parts of the army. But Lee pretended to regard the order in the light of mere advice, raised objections, fumed and quibbled, and did not stir. While Washington was now obliged to fall back through New Jersey, in order to avoid fighting against overwhelming odds, his daily messages to Lee grew more and more peremptory, but no heed was paid to them. Many people were throwing the blame for the loss of Fort Washington upon the commander-in-chief, and were contrasting him unfavourably with the "hero of Charleston "; and Lee, instead of obeying orders, busied himself in writing letters calculated to spread and increase this disaffection toward Washington. Among his correspondents were some of the men who in the course of the next year became implicated with the Conway cabal, such as Gates and Dr. Benjamin Rush. In letters to prominent New England men, he tried to play upon the most contemptible of all the mean feelings that disgrace human nature, - the feeling of sectional dislike and distrust which many in that part of the country entertained toward the great Virginian. At the same time he tried to assume command over General Heath, whom Washington had left in charge of the Highlands with very explicit instructions. Lee wished to detach part of Heath's force, and announced that since a broad river intervened 
between himself and Washington, he now considered himself invested with an independent command. But for courage and fidelity Heath was a true bulldog. Lee's letters to him grew more and more angry. "I suppose you think," said Lee, "that if General Washington should remove to the Straits of Magellan, nevertheless the instructions he left with you are to be followed in spite of what your superior officers might say; but I will have you to understand that I command on this side of the river, and for the future I must and will be obeyed." ${ }^{1}$ Heath, however, was immovable; and a letter from Washington, arriving the next day, declared his own view of the case in such unequivocal language that Lee did not deem it prudent to push his Patagonian theory any farther. So he desisted, with a very ill grace, and on the $2 \mathrm{~d}$ of December, after a fortnight's delay, he crossed the Hudson, with a force diminished to four thousand men. On that same day Washington in his swift retreat reached Princeton, with his force diminished to three thousand men. The terms of service of many of the soldiers had expired, and the prospect was so dismal, that few were willing to reënlist. It was the gloomiest moment in the Revolutionary War and in Washington's career; and the most alarming feature in the whole situation was this outrageous insubordination on the part of Lee. Washington had ordered him to keep well to the westward, and had even indicated the particular road and ferry by which he wished him to cross the Delaware, near Alexandria, but in flat disregard of these orders Lee marched slowly to Morristown. At this moment Gates was approaching, on his way from

${ }^{1}$ Lee Papers, II. $3^{1} 3$. 
Ticonderoga, with seven regiments sent down by Schuyler to Washington's assistance; but Lee interposed, and with more success than he had had in Heath's case, diverted three of these regiments to Morristown. By this time Washington had retreated beyond the Delaware, and almost everybody considered his campaign hopelessly ruined. It seemed as if the cause of American independence was decisively overthrown, and it certainly was not Charles Lee's fault that it was not so. His design in thus moving independently was to operate upon the British flank from Morristown, a position of which Washington himself afterward illustrated the great value. The selfish schemer wished to secure for himself whatever advantage might be gained from such a movement. His plan was to look on and see Washington defeated and humbled, and then strike a blow on his own account. If Cornwallis had prevailed upon Howe to let him collect a flotilla of boats and push on across the river in pursuit of Washington, there would have been a chance offered to Lee to strike the enemy's rear before the crossing had been fully effected. But Howe, perhaps mindful of such a contingency, decided to wait a few days in the hope of seeing the river frozen hard enough to bear troops. In the meantime Lee's castle in the air was overthrown by his own foolishness. On the $3^{\text {th }}$ of December, having left his army in charge of Sullivan, he had for some unknown reason passed the night at White's tavern in Baskingridge, about four miles distant. A zealous Tory in the neighbourhood had noted the fact, and galloped off to the nearest British encampment, eighteen miles distant. Lieutenant-colonel Harcourt, with Captain Banastre 
Tarleton and a party of thirty-eight horse, immediately started forth in quest of such high game. At daybreak young Major Wilkinson arrived at the inn, with a message from Gates, and found Lee in bed. The general jumped up, thrust his feet into slippers, threw on an old flannel gown over his nightclothes, and proceeded to write a letter to Gates, setting forth his own exalted merits and Washington's matchless stupidity. He had hardly signed and folded it when Wilkinson at the window screamed, "The British! the British!" In the twinkling of an eye the house was surrounded and the blustering letter-writer dragged from his bedroom. Several of these soldiers had served with Lee in Portugal and witnessed his gallantry at Villa Velha. They were now surprised and disgusted at seeing him fall on his knees in abject terror, raving like a madman and begging Colonel Harcourt to spare his life. "Had he behaved with proper spirit," says Captain Harris, in his journal, "I should have pitied him." No time was wasted. They picked him up, bareheaded and half-dressed, mounted him on Wilkinson's horse, tied him hand and foot, and led him off, with taunts and mirthful jeers. Of course, they said, he must not be surprised if General Howe were to treat him as a deserter, because he was one. The miserable creature muttered and cursed, and let fall one remark which they did not quite comprehend. "Just as I had got the supreme command," said he, ${ }^{1}$ and presently added, "The game is up, it is all up." So they carried him off to New Brunswick, while his troops, thus opportunely relieved of such a commander, were promptly marched by Sullivan to Washington's assist-

${ }^{1}$ Moore, p. 63. 
ance, in time to take part in the glorious movement upon Trenton and Princeton. Had it not been for Lee's capture, in the very nick of time, it is doubtful if Washington would have had men enough to undertake that movement, which instantly reversed the fortunes of the campaign and opened the way for the decisive triumphs of the next year. But the Americans, who did not possess the clew to Lee's strange conduct, felt that they had lost a treasure.

Of his conduct in captivity, which would soon have afforded such a clew, nothing was known until all the actors in those stirring scenes had been for many a year in their graves. Lee was taken to New York and confined in the City Hall, where he was courteously treated, but he well understood that his life was in danger in case the British government should see fit to regard him as a deserter from the army. Sir William Howe wrote home for instructions, and in reply was directed to send his prisoner to England for trial. Lee had already been sent on board ship, when a letter from Washington put a stop to these proceedings. The letter informed Howe that Washington held five Hessian field-officers as hostages for Lee's personal safety. In thus choosing Hessians as hostages, Washington showed his unfailing sagacity. The king's feeling toward Lee was extremely bitter and revengeful, and no doubt he would have taken pleasure in putting him to an ignominious death; but to disregard the safety of the Hessian officers would arouse a dangerous spirit of disaffection among the German troops. In this quandary the obstinate and vindictive king entered upon a discussion that lasted just a year. Letters went back and forth between Howe and the 
ministry on the one hand, and Howe and Washington on the other, until at length, in December, 1777 , Howe was instructed to consider Lee a prisoner of war, and subject to exchange as such whenever convenient.

During this interval, while his fate was in suspense, the prisoner was busy in operations on his own account. First he assured the brothers Howe that he was opposed to the Declaration of Independence; that "if the Americans had followed his advice, matters could never have gone to such a length;" ${ }^{1}$ and even now he hoped, if he could only obtain an interview with a committee from Congress, to be able to open negotiations for an honourable and satisfactory adjustment of all existing difficulties. The Howes, who were well disposed toward the Americans and sincerely anxious for peace, allowed him to ask for the interview; but Congress refused to grant it. Lee's extraordinary conduct before his capture had somewhat injured his reputation, and there were vague suspicions, though no one knew exactly what to suspect him of. These doubts affected the soundness of his judgment rather than of his character. His behaviour was considered wayward and eccentric, but was not seen to be treacherous. The worst that was now supposed about him was that he had suffered himself to be hoodwinked by the Howes into requesting a conference that could answer no good purpose. If the truth had only been known, how sorely would all good people have been astonished! No sooner was the conference refused than the wretch went over to the enemy, and sought to curry favour with the Howes by

${ }^{1}$ Moore, p. 83 . 
giving them aid and counsel for the next campaign against the Americans. He went so far as to write out for them a detailed plan of operations. After the disastrous result of the campaign of 1777 the brothers did not wish to disclose the secret of their peculiar obligations to such an adviser. Lee's document remained in possession of their private secretary, Sir Henry Strachey, who carried it home to England next year, and carefully stowed it away with other papers in the library at Sutton Court, his fine, hospitable old country house in Somersetshire. There, after a slumber of eighty years, it was found and perused by intelligent eyes, ${ }^{1}$ and it has since found its way into the Lenox Library in New York. The paper is in Lee's handwriting, folded, and indorsed as "Mr. Lee's Plan -29th March 1777." The indorsement is in the handwriting of Sir Henry Strachey. In this paper Lee expressly abandons the American cause, enters "sincerely and zealously" (those are his words) into the plans of the British commanders, and recommends an expedition to Chesapeake Bay essentially similar to that which was undertaken in the following summer. This elaborate paper throws some light upon the movements of General Howe, in July and August, I 777, which were formerly regarded as so strange. Instead of moving straight up the Hudson River, to coöperate with Burgoyne in accordance with the carefully studied plan of the ministry, General Howe wasted the summer in a series of movements which landed him at the end of August fifty miles south of Philadelphia, with Washington's army in front of him, while the gallant Burgoyne, three hundred miles away,

\section{${ }^{1}$ Magazine of. American History, III. 450.}


was marching to his doom. This supreme blunder on the part of Howe was ruinous to the British cause. It led directly to the surrender of Burgoyne, and thus to the French alliance and indirectly to Yorktown. The blunder was no doubt largely due to Lee's wild advice, but we owe him small thanks for it. It is impossible to read his paper and not see that in his stupendous conceit he regarded himself as the palladium of the American cause. His capture he regarded as the final overthrow of that cause. What was left of it could be of no use to anybody, and he had better secure good terms for himself by helping to stamp it out as quickly as possible.

If anything had been known about these treacherous shifts on the part of Lee, he certainly never would have been taken back into the American service. As nothing whatever was known about the matter, he was exchanged for General Richard Prescott early in May, I 778, and joined Washington's army at Valley Forge. What a frightful situation for the Americans: to have, for the second officer in their army, the man whom the chances of war might at any moment invest with the chief command, such a man as this who had so lately been plotting their destruction! What would Washington, what would Congress, have thought, had the truth in its blackness been so much as dreamed of? But why, we may ask, did the intriguer come back? Why did he think it worth his while to pose once more in the attitude of an American? Could it have been with the intention of playing into the hands of the enemy? and could the British commander, knowing this purpose, have thus gladly acquiesced in his return? It is hard to say, but probably this explanation is too 
simple to cover the case. We must remember that Sir William Howe, the Whig general, had just resigned his command and gone home to defend his military conduct against the fierce attacks of the king's party. His successor, Sir Henry Clinton, was not only a Tory, but the personal relations between the two were not altogether friendly; so that it is hardly credible that Clinton could have known anything about Lee's coöperation with Howe; if he had known it, the secret would not have been buried for eighty years. It is much more likely that, since the disastrous failure of Lee's advice, he was reduced to painful insignificance in the British camp, and so thought it worth while to try his fortune again with the Americans. The past year had seen the tables completely turned. The American star was now in the ascendant; most people expected to see the British driven to their ships before autumn; and Lord North's commissioners were on their way across the ocean, to offer terms of peace. While Lee could see all this, he could not see how greatly Washington's popular strength had increased during the past winter, as the intrigues against him had recoiled upon their authors. The days of the Conway cabal were really gone by, but this was not yet apparent to everybody. The ambitious schemes of Gates were frustrated, and Lee might now hope again to try his hand at supplanting Washington, with one more rival out of the way. Indeed, there is some reason for believing that the very schemers and sycophants who had been putting Gates forward were always ready, if occasion should offer, to drop him and take up Lee instead. Doubtless, therefore, Lee came back in the renewed hope of supplanting Washington. 
Whether he can also have had any secret understandings with the enemy, it is hard to say. A very friendly letter from a British gentleman, George Johnson, dated at Philadelphia, the $\mathrm{I} 7$ th of June, and addressed to General Lee at Valley Forge, observes in its postscript, "Sir Henry Clinton bids me thank you for your letter." ${ }^{1}$ What this letter may have referred to, or whether it is still anywhere in existence, or whether there was any further correspondence between Clinton and Lee, we do not know. Sir Henry had, at any rate, probably seen and heard enough to confirm the declared opinion of Sir Joseph Yorke, that such a man as Charles Lee was "the worst present the Americans could receive." In the campaign just beginning he proved himself to be such.

When, in June, Sir Henry Clinton evacuated Philadelphia, it was his purpose to retreat across New Jersey to the city of New York without a battle, if possible. It was Washington's object to attack Clinton on his retreat, cut to pieces the rear division of his army, and thus essentially cripple him. Lee at first endeavoured to dissuade Washington from making such an attack. Then, when it was resolved to make the oblique attack upon the rear division, with the purpose of cutting it asunder from the advanced division, Lee showed such unwillingness to undertake the task that Washington assigned it to Lafayette. Each of the opposing armies numbered about fifteen thousand men, and since the arrival of Steuben, with his Prussian tactics and discipline, the quality of the American troops had been signally improved. Each army was marching in two divisions, three or four

${ }^{1}$ Lee Papers, II. 406. 
miles apart. The American advance, of about six thousand men, under Lafayette, was to attack the British rear division upon its left flank and engage it until Washington, with the remainder of the army, should come up and complete its discomfiture. At the last moment Lee changed his mind and solicited the command of the advance. The nobleness of Washington's nature made him very kind in his judgments of other men. He was always ready to make allowances, and up to this time he had found some charitable interpretation for Lee's behaviour. Now he showed the defects of his excellence, and was too trustful. He so arranged matters that Lee should have the command, and Lafayette most gracefully yielded the point. Washington's orders to Lee were explicit and peremptory. On the morning of the 28th of June the advance division overtook the enemy near Monmouth Court House. The position was admirable for an oblique attack upon the British flank, and in the opinion of Anthony Wayne and other brigade commanders a prompt and spirited attack was called for. But the fighting had scarcely begun when Lee's conduct became so strange and his orders so contradictory as to excite uneasiness on the part of Lafayette, who sent a messenger back to Washington, urging him to make all possible haste to the front. When the commander-in-chief, with his main force, had passed Freehold church on his way toward the scene of action, he was astonished at the spectacle of Lee's division in disorderly retreat, with the enemy close upon their heels. A little farther on he met the faithless general. The men who then beheld Washington's face, and listened to his terrific outburst of 
wrath, could never forget it for the rest of their lives. ${ }^{1}$ It was one of those moments that live in tradition. People of to-day who know nothing else about Charles Lee think of him vaguely as the man whom Washington upbraided at Monmouth. People who know nothing else about the battle of Monmouth still dimly associate it with the disgrace of a General Lee. Leav-

${ }^{1}$ The following letter gives a version of the rebuke :-

"Professor John Fiske :-

"Charlotteville, Va., Oct. 26, 1895.

"Dear Sir:-At your request, I have reduced to writing the incident I related to you last evening, at the reception, after your lecture upon General Charles Lee - 'The Soldier of Fortune.'

"I am, Sir,

"Yours faithfully,

"WM. ROBERTSON.

"In the year 1840, while I was a student at Hampton, Sydney College, and boarding in the family of Mrs. Ann Rice (the widow of the Rev. John H. Rice, D.D.), her father, Major Jacob Morton, a Revolutionary soldier, living in an adjoining county (Cumberland), came to visit her. Major Morton was then upward of eighty years old, but still in full possession of all his mental faculties. . . .

"The talk at the dinner table was of his reminiscences of the Revolutionary War . . . the Battle of Monmouth. . . I I sought an opportunity of further conversation with him, and having heard or read that just before that battle General Washington, on meeting General Charles Lee in retreat, had 'cursed and swore' at him, I asked Major Morton whether that report was true. 'No, sir! No, sir!' replied the major with animation. 'It is not true! It so happened that the meeting of General Washington with General Lee on that day took place within a very few yards of me, and I saw and heard all that passed between them. I will tell you how it was. Our troops were marching rapidly, expecting soon to be engaged with the British; the day was very hot, the road heavy with sand, our men fatigued by the march. I was then a sergeant in my company and had frequently to face about in order to keep my platoon aligned on the march, myself walking backwards. While doing so, I saw General Washington coming from the rear of our column, riding very rapidly along the right flank of the column; and as he came nearer, my attention was fixed upon him with wonder and astonishment, for he was evidently under strong emo- 
ing the cowering and trembling culprit, Washington hurried on to rally the troops and give the orders which turned impending defeat into victory. As he rode about the field, his suspicions of foul play were more and more thoroughly aroused, and presently, meeting Lee again, he ordered him to the rear. The

tion and excitement. I never saw such a countenance before. It was like a thunder-cloud before the flash of lightning. Just as he reached the flank of my platoon he reined up his horse a little, and raising his right hand high above his head, he cried out with a loud voice, "My God! General Lee, what are you about ?" Until that moment I had not known that General Lee was near; but on turning my head a little to the left (still stepping backward on the march) I found that General Lee had ridden from the head of our column along our right flank and was only a few yards distant, in front of General Washington. In answer to General Washington's excited exclamation, "My God! General Lee, what are you about?" General Lee began to make some explanation; but General Washington impatiently interrupted him, and with his hand still raised high above his head, waving it angrily, exclaimed, "Go to the rear, sir," spurred his horse, and rode rapidly forward. The whole thing occurred as quickly as I can tell it to you.'

"This conversation with old Major Morton interested me profoundly and made a deep impression upon my memory. My recollection of it is still (after the lapse of about fifty-five years) clear and distinct. What I have written about it, if not in his very words, is substantially what he told me. The words, 'My God! General Lee, what are you about ?' are the very words which he declared that General Washington uttered. I will add that Major Morton, in all the region of country in which he spent his long life, was reputed to be a man of the very highest integrity - no one who ever knew. him ever doubted or questioned his veracity. Indeed, he was proverbial for honesty, courage, and veracity. Altho' only a sergeant at the date of the battle of Monmouth, he afterward rose to the rank of a major in the Revolutionary Army ; and in the service acquired the sobriquet of 'Solid Column.' When, in 1825 , General Lafayette revisited the United States, and held a levee at Richmond, Va., at which many of the surviving officers and soldiers of the Revolution from various parts of the state of Virginia attended, and were successively presented to him ; as Major Morton's turn came to be presented, Lafayette said, cordially, 'Oh, it is not necessary to introduce "old Solid Column" to me, I remember him well.'

"WM. RobERTSON." 
next day Lee, having recovered his self-possession and thought of a line of defence, wrote to Washington demanding an apology for his language on the battlefield. Washington replied that he believed his words to have been fully warranted by the circumstances, and added that a court-martial would soon afford General Lee an opportunity for explaining his conduct. "Quite right," answered Lee; "you cannot afford me greater pleasure than in giving me the opportunity of showing to America the sufficiency of her respective servants. I trust that the temporary power of office, and the tinsel dignity attending it, will not be able, by all the mists they can raise, to obfuscate the bright rays of truth." " Washington answered by placing Lee under arrest. He was tried by court-martial on three charges : (I) Disobedience of orders in not attacking the enemy. (2) Misbehaviour before the enemy in making an unnecessary, disorderly, and shameful retreat. (3) Gross disrespect to the commander-in-chief. On the 1 2 th of August he was found guilty on all three charges, and suspended from all command in the army for the term of one year.

For a long time Lee's conduct at Monmouth seemed quite unintelligible. The discoveries since made regarding his behaviour in captivity do not yet clear it up, though they make it seem susceptible of the worst interpretation. If we suppose that he was actually in collusion with Clinton, the simplest supposition is that he intended to wreck the army; and certainly few things could be better calculated to do so than throwing a mass of disorderly fugitives in the face of the advancing reënforcements. But I believe the true

${ }^{1}$ Lee Papers, II. 437. 
explanation is not quite so simple as this. It does not seem probable that there was any secret understanding with Clinton. It is much more likely that Lee was again at his old trick of trying to discredit and supplant Washington. With this end in view he first loudly condemned Washington's plan of battle and refused to take the part assigned him. On second thought it occurred to him that by taking that command he might insure the defeat of Washington's plan, and still bring off the army to such a position that he might claim the credit for having saved it from the effects of Washington's rashness. This explanation is indicated by the line of defence which he chose upon his trial. His retreat lay across two deep ravines, and it was upon the brink of the second one that Washington met him. He argued ingeniously before the court-martial that if he had attacked as Washington directed, the result would have been disastrous; but in his retreat he was simply luring the enemy across these ravines into a position where he could suddenly turn upon him and defeat him with a dangerous ravine at his back. All this would have been done, he declared, if Washington had not come up and spoiled the game. This explanation may have been concocted after the event; but it is not unlikely that Lee may really have entertained some such wild scheme. A very difficult plan it would be to carry out, especially with his brigade conmanders all hopelessly bewildered. Confusion could not but result, and well indeed it was that the reins of the runaway team were suddenly seized by the powerful hand of Washington.

Such is the explanation least unfavourable to Lee. Even on his own showing it is one of the most out- 
rageous cases of insubordination recorded in the annals of war. But one incident, mentioned in the testimony of Steuben, throws perhaps the blackest shade upon the conduct of this miserable creature. After Lee had been ordered to the rear, as he rode away baffled and spiteful, he met Steuben with a couple of brigades hurrying to the front in pursuance of an order just received from Washington. Lee now tried to turn him off in another direction, alleging that the order was misunderstood. But the good baron was not to be trifled with and resolutely kept on his way. ${ }^{1}$ Lee was so enraged at this testimony that he made reflections upon Steuben, which presently called forth a challenge from that gentleman. ${ }^{2}$ That "sprightliness of imagination" heretofore mentioned seems now to have deserted our soldier of fortune. It is to be regretted that we have not the reply in which he declined the encounter. There is a reference to it in a letter from Alexander Hamilton to the Baron von Steuben, a fortnight after the challenge: "I have read your letter to Lee with pleasure. It was conceived in terms which the offence merited, and if he had any feeling, must have been felt by him. Considering the pointedness and severity of your expressions, his answer was certainly a very modest one, and proved that he had not a violent appetite for so close a tête-àtête as you seemed disposed to insist upon. His evasions, if known to the world, would do him very little honour." ${ }^{3}$ Upon what grounds Lee refused to fight with Steuben, it is hard to surmise; for within another week we find him engaged in a duel with ${ }^{1}$ Lee Papers, III. 96. ${ }^{2}$ Id. 253 . 
Washington's aide-de-camp, Colonel Laurens, for whom Hamilton acted as second. ${ }^{1}$ In this affair Lee was slightly wounded in the right arm. His venomous tongue now kept getting him into trouble more than ever. He could not hear Washington's name mentioned without losing his temper. After some time he addressed one of his impudent letters to Congress, and was immediately dismissed from the army. $\mathrm{He}$ retired in disgrace to his estate in the Shenandoah valley, and lived there long enough to witness the final triumph of the cause he had done so much to injure. On a visit to Philadelphia he was suddenly seized with a fever, and died in a tavern, friendless and alone, on the $2 \mathrm{~d}$ of October, $\mathrm{I} 782$. His last words, uttered in delirium, were, "Stand by me, my brave grenadiers!" A scoffer to the last, he had expressed in his will a wish that he might not be buried within a mile of any church or meeting-house, as since his arrival in America he had kept so much bad company in this world that he did not wish to continue it in the next. $\mathrm{He}$ was buried, however, in the cemetery of Christ Church, and his funeral was attended by the President of Congress and other eminent citizens.

General Lee was one of the numerous persons credited with the authorship of the famous "Letters of Junius," and the way in which this came to pass is worthy of notice for the further illustration it affords of his character. In a letter dated at Dover, February I, 1803, published in the Wilmington Mirror and copied into the St. James Chronicle, London, Mr. Thomas Rodney gave the substance of a conversation between himself and General Lee in I773. That

${ }^{1}$ Id. 283 . 
was the year when Lee came to America and travelled up and down the country in order to impress upon the minds of our people his great importance in the European world. In the course of this conversation Lee observed that not a man in the world but himself, not even the publisher, knew the secret of the authorship of "Junius." Rodney naturally replied that no one but the author himself could make such a remark as that. Lee started. "I have unguardedly committed myself," said he, "and it would be folly to deny you that I am the author; but I must request you will not reveal it during my life, for it never was and never will be revealed by me to any other." Lee then went on to point out several circumstances corroborative of his claim. Such a statement, from a gentleman of such high character as Mr. Rodney, at once attracted attention in Europe and America. Two intimate friends of Lee maintained opposite sides of the question. Ralph Wormeley of Virginia published a letter in which he argued that Lee was very far from possessing the knowledge of parliamentary history exhibited in the pages of "Junius." Daniel McCarthy of North Carolina published a series of articles in the Virginia Gazette in refutation of Wormeley. Dr. Thomas Girdlestone of Yarmouth, England, followed on the same side in a small volume entitled, "Facts tending to prove that General Lee was never absent from this country for any length of time during the years I 767I 772, and that he was the author of 'Junius.' " This curious little book was published in London in I8I 3 . The first part of Dr. Girdlestone's title points to the fatal obstacle to his hypothesis. The simple fact is that Lee was absent in such remote countries as 
Poland and Turkey at the very dates when "Junius" was publishing letters exhibiting such minute and detailed acquaintance with affairs every day occurring in London as could only have been possessed by an eye-witness living on the spot. This fact makes it impossible that he should have written the "Letters of Junius"; and Mr. Rodney's statement only goes to show that, in other than military matters, the soldier of fortune was willing to claim what did not belong to him.

Such was the man to whom some of our greatgrandfathers were at times almost ready to intrust the destinies of their country rather than to George Washington! When we consider how narrowly the cause of American independence escaped total wreck at the hands of this unprincipled adventurer, the thought is enough to make us shudder after the hundred years that have passed. In judging the character of the man, there may be found some who would urge that his eccentricities were so marked as perhaps to afford some ground for the plea of insanity whereby to palliate his misdemeanours. One will not grudge him the benefit of such a plea, in so far as it may have any value. His mind was no doubt ill balanced, or, to use one of his own favourite words, it was " unhinged" by colossal vanity and ravening selfishness; and accordingly, what chiefly strikes us now in reviewing his career is the contrast between his enormous pretensions and his unparalleled feebleness. We shall have to search the field of modern history far and wide to find his equal as a charlatan. In comparison with such a man even the figure of Benedict Arnold acquires dignity. We can imagine 
the latter admired and trusted in some circles of the lower world. But Charles Lee belongs rather to that limbo described by Dante as the final home of those caitiff souls a Dio spiacenti ed ai nemici sui, too wicked for the one place, too weak for the other. 
III

\section{ALEXANDER HAMILTON}

AND THE FEDERALIST PARTY 



\section{III}

\section{ALEXANDER HAMILTON}

\section{AND THE FEDERALIST PARTY}

THE 6th of July, I774, was a memorable day in the history of New York. The question as to how far that colony would go in support of Massachusetts in its defiance of Parliament was pressing for an answer. Parliament had in April passed an act which deprived Massachusetts of her charter, and another which shut up the port of Boston until the town should see fit to pay the East India Company for the tea which had been thrown into the harbour. On the ist of June Hutchinson had sailed for England, hoping through a personal interview with the king to effect a repeal of these tyrannical acts, and on the same day Thomas Gage, intrusted with the work of enforcing them, assumed military command over Massachusetts. Troops were encamped on Boston Common, frigates rode at anchor in the harbour, great merchantmen lay idle at the wharves while sailors and shipwrights roamed the streets or sat drinking in the taverns. The legislature was convened at Salem, where on the I 7 th Samuel Adams achieved a master stroke and carried the resolutions inviting all the sister colonies to join in a Continental Congress, to meet at Philadelphia on the ist of September. Rhode Island and Maryland had at once elected delegates to attend the proposed Congress. In Virginia a convention was about to be 
held, and such expressions of opinion had come from that quarter as to leave no doubt as to what its action would be. The time had arrived when New York must do something. But what she should do was hard to determine, for parties were quite evenly balanced.

The king, indeed, in his harsh measures against Massachusetts relied confidently upon the support of New York. He believed that his Tory friends there were in a decided majority, and they declared there would be no Congress. As for New York, they said, "She will never appoint delegates; Massachusetts must be made to feel that she is deserted." There was something more in this than the old local dislike between New York and New England. For thirteen years Massachusetts had been suffering-acute irritation at the hands of crown officers, and her temper had thus grown so belligerent that in most parts of the country there was a disposition to regard her as perhaps a little too obstinate and fierce. There were people in New York who thought that both Massachusetts and the king were going too far, and persuaded themselves that the tea might be paid for without surrendering the principles which had led to its destruction. Some who were about to become eminent as Revolutionary leaders had not yet fully made up their minds. Tory politicians led in the Committee of Correspondence, and on the $4^{\text {th }}$ of July, while it was decided to take part in the Congress, on the other hand the delegation which was appointed seemed to the extreme Whigs too conservative in character. The Sons of Liberty, who feared that Massachusetts would not find due support in the Con- 
gress, were well represented in the city of New York. At their head were the merchants, Isaac Sears and Alexander Macdougall, and the eloquent lawyer, John Morin Scott. The Tories used to sneer at these men as "the Presbyterian junto." They wished to reconsider the action of the committee, and to make a popular demonstration which would go as far as possible toward committing New York to espouse the cause of Massachusetts. Accordingly, on the 6th of July, a great meeting of citizens was held in the fields north of the city, with the canny Scotchman, Macdougall, as chairman. Many eminent speakers addressed the meeting, but among the hearers was a lad of seventeen years, small and slight in stature, who listened with intense eagerness as he felt that, besides all that was said, there were other weighty arguments which seemed to occur to nobody. At length, unable to keep silence any longer, he rose to his feet, and somewhat timidly at first, but gathering courage every moment, he addressed the astonished company. His arguments compelled assent, while his dignified eloquence won admiration, and when he had finished there was a buzz of inquiry as to who this extraordinary boy could be. There were some who had seen him walking back and forth under the shade of some large trees in Dey Street, absorbed in meditation and now and then muttering to himself; a few knew him as "the young West Indian"; on further inquiry, it appeared that he was a student at King's College, and his name was Alexander Hamilton.

Instances of marvellous precocity are more often found in mathematics, or linguistics, or music, than in political science; for in the latter case something 
more than consecutive thinking or tenacious memory or a fine artistic sense are required; there is needed an insight into human nature and the conditions of human life such as can hardly be acquired save by long years of experience. Seldom has there been such a case as that of Hamilton. His intellect seemed to have sprung forth in full maturity, like Pallas from the brain of Zeus. What little is known of his childhood and youth can be told in few words. Alexander Hamilton was born upon the island of Nevis, in the West Indies, on the I Ith of January, 1757. His father belonged to the famous Scottish family of the Hamiltons of Grange, his mother was daughter of a Huguenot gentleman named Fawcette, who had fled to the West Indies after the revocation of the Edict of Nantes. He was equally at home in the English and French languages. His father fell into financial difficulties, and his mother died during his childhood, so that he was placed at school at Santa Cruz under the care of some of her relatives. His school studies were accompanied by a wide course of miscellaneous reading, assisted by the advice of Dr. Hugh Knox, a kindly and sagacious Presbyterian minister and a graduate of Princeton. Before his thirteenth birthday he entered the counting-house of Nicholas Cruger, a merchant, who carried on a very considerable business. Here his wonderful precocity soon showed itself. Business letters of his, written at that period, have been preserved which would do credit to a trained business man; and before the boy had been a year in the house, his employer, having occasion to leave the island, intrusted its entire management to him. In spite of this extraordinary apti- 
tude, for the work he felt no special fondness. In a letter dated just two months before he was thirteen, he thus unbosomed himself to a schoolmate: "To confess my weakness, Ned, my ambition is prevalent, so that I contemn the grovelling ambition of a clerk, or the like, to which my fortune condemns me, and would willingly risk my life, though not my character, to exalt my station. I am confident, Ned, that my youth excludes me from any hope of immediate preferment, nor do I desire it; but I mean to prepare the way for futurity. I'm no philosopher, you see, and may be justly said to build castles in the air; my folly makes me ashamed, and beg you'll conceal it. Yet, Neddy, we have seen such schemes successful, when the projector is constant. I shall conclude by saying, I wish there was a war."

The reading of Plutarch has awakened generous ambition in many a youthful mind. Hamilton "prepared the way for futurity" by studying and commenting upon this author, and by trying his hand at literary composition. In August, I772, the island was visited by a terrible hurricane; and a remarkable description of it, published in a newspaper at St. Christopher, attracted general attention throughout the British West Indies. The authorship was traced to Hamilton; it was decided that such literary talent required wider opportunities than were furnished on the islands; the needful funds were raised by subscription; and before the end of October the boy's romantic temperament was at once gratified and stimulated, as he found himself on board ship headed for Boston, with potent letters of introduction from Dr. Knox in his pocket. The connection with this 
Presbyterian divine led him to New Jersey, where he entered a grammar school at Elizabethtown, and for a while made his home in the house of William Livingston. There he was introduced to the best society, and met many good friends, among them John Jay, who was soon to marry one of the four charming daughters. A full year had not passed when he was declared fit to enter Princeton, and he called upon Dr. Witherspoon, the able president, with the request that he might be allowed to advance toward his degree as fast as he could pass the examinations, and without regard to the prescribed curriculum. When the request was refused by the trustees as vain and unreasonable, he repaired to New York, and succeeded in entering King's College (now Columbia) upon his own terms.

This was late in the autumn of 1773 , the stirring season of the Boston Tea Party. Hamilton's wish for a war was soon to be gratified. His childhood had been passed in an atmosphere of loyalism; he knew little as yet of American politics; his instincts were then, as always, in favour of strong government, and opposed to anything that looked like insurrection, and his first impressions leaned toward the Tory side. But he had hardly been six months at college when he happened to visit Boston, about the time when news arrived of the vindictive acts of Parliament and the appointment of a military governor. It was a good place and a good time for comprehending the true character of the political situation. The young man mastered the arguments with his usual swiftness and thoroughness, and returned to New 
York in time to exert a powerful influence upon the great assemblage in the fields. The practical result of the meeting was seen a few weeks later, when the delegates embarked at Cortlandt Street to the sound of drum and trumpet, pledged to "support at the risk of everything dear" such resolutions as the Continental Congress might see fit to adopt.

Soon after the Congress had adjourned in October, to await the results of its action upon the British government, its proceedings were adversely criticised in two able pamphlets written jointly by two Episcopal clergymen, the famous Samuel Seabury, afterward Bishop of Connecticut, and Isaac Wilkins of Westchester County. The pamphlets, which purported to come from "A Westchester Farmer," cast dismay into the ranks of the Whigs. They were extremely plausible, and were already making converts, when within a fortnight there appeared an anonymous tract in vindication of Congress, which at once threw the "Farmer" upon the defensive, and ruffled his temper withal, as his next pamphlet showed. The anonymous writer returned to the charge with a voluminous essay quite properly entitled "The Farmer Refuted"; it completely unhorsed and disarmed the adversary; the two ministers had no more to say. Great curiosity was felt as to the anonymous writer. Some thought it must be Jay, others his father-in-law, Livingston. When it was at length ascertained that it was a boy of eighteen, and the same boy that had addressed the meetings in the fields, the astonishment was profound. There was no trace of immaturity in thought or expression in his two essays, and their boldness of tone was accompanied by a grasp of the political situation 
that must seem even more remarkable to-day than it did at the time, since we can appreciate the writer's foresight as contemporaries necessarily could not. At the beginning of 1775 very few leaders, even in Massachusetts or Virginia, were in favour of independence. The author of "The Farmer Refuted" hints at independence as the possible outcome of the quarrel, indicates a Fabian military policy as most likely to baffle Great Britain, and surmises that France and even Spain might find it for their interest to take part in the struggle. That such advanced views could have been even suggested without weakening the effect of the pamphlet shows a tact and an artfulness of statement not less remarkable than the other qualities of the young writer.

It was not long before the news of Lexington wrought the excitement in New York to fever heat. There were strect fights between Tories and Whigs, and here Hamilton's hatred of anarchy was well illustrated. To him independence was one thing, mob law quite another. A party of rioters beset the house of Dr. Cooper, the Tory president of the college, with intent to seize him and in some way maltreat him. Hamilton got into the foremost rank of the crowd till he reached the door-step, then faced about and addressed the rioters, and held them at bay while the doctor escaped through the back garden and took refuge on the deck of a British seventy-four. Presently, when Isaac Sears raised a troop of horse over in Connecticut and dashed into New York at their head to attack Rivington's Tory printing-press, Hamilton incurred no little risk in confronting them with arguments and expostulations. The press was destroyed 
and the Tory type carried off to Connecticut to be melted into Whig bullets. ${ }^{1}$

By this time the boy was ranked among the leading spirits of the Whig party. He had already begun to study the military art, and now joined a corps of young men, chiefly college students, known as "Hearts of Oak." They wore green coats and leather caps adorned with the motto, "Freedom or Death," and they were drilled and paraded daily until they became a model of discipline. On the I 4 th of March, I 776 , Hamilton was appointed captain of the first company of artillery raised by the state. Presently the thoroughness of its drill and the grace of its movements caught the keen eye of that great genius and eager military student, Nathanael Greene, who arrived in New York on the 17 th of April. Greene was so impressed that he sought Hamilton's acquaintance and spoke of him enthusiastically to Washington. The young captain and his company did good service at the battle of Long Island and the retreat which followed; and again at White Plains and Trenton and Princeton. On the Ist of March, I 777, he accepted a position on Washington's staff, with the rank of lieutenant-colonel. It was with some reluctance that he took this place, for he had been looking forward to promotion in the line; but what he lost in one direction he probably more than gained in another, through the peculiarly intimate relations into which he entered with Washington. His great work was to be, not that of a general, but of a statesman; and there was no place more favourable than Washington's staff for studying minutely into the causes of the miserable weakness

\footnotetext{
1 Morse's "Hamilton," I. 19.
} 
which the imperfect union between the states entailed upon the whole country, or for discussing the most proper measures for remedying this condition of affairs through the establishment of a more perfect union. The impossibility of raising a national revenue, save from precarious foreign loans or the wretched expedient of issuing promissory notes without any discoverable means of paying them, was a source of perpetual anxiety to the commander-in-chief. The consequences of this poverty were daily brought home to his headquarters in the difficulty of enlisting troops, or of supplying them with clothing and ammunition, or of paying them even a small instalment of wages overdue. At the end of the war there was no one who could have told better than Hamilton how hard it had sometimes proved to keep the army from melting away, or how many times some promising military scheme had been nipped in the bud for want of supplies, while men in Congress and in the state legislatures were wondering why Washington could not march without shoes, sup without food, fight without powder, and defeat a well-equipped and well-fed enemy that outnumbered him two to one. No one understood better than Hamilton that, but for the radical want of efficiency in the government of the confederation, such obstacles would have been far less formidable, and the enemy might much sooner have been driven from the country. No doubt the daily intercourse for four years between Washington and his confidential aide added much to the strength of both, and to the effectiveness with which they were afterward able to reënforce one another in contributing to found a better government. Almost from the outset Washington 
consulted Hamilton more frequently than the other members of his staff and intrusted the most weighty affairs to his charge. It was remarkable that this preference, accorded to so young a man, should have excited no jealousy. But the "little lion," as the older officers called him, was so frank and good-natured, so buoyant and brave, and so free from arrogance, that he won all the hearts. There was a mixture in him of Scottish shrewdness with French vivacity that most people found irresistible. Knox and Laurens, Lafayette and Steuben, loved him with devoted affection.

Along with the desire to please, which was one secret of his attractiveness, there was a due amount of sternness latent, as appeared when occasion called for it. If necessary, the "little lion" could command in a tone that made weaker creatures tremble. All his tact and all his imperiousness were required on his mission to Saratoga after Burgoyne's surrender, to get back the troops which Washington had sent to Gates and which the latter no longer needed. Gates was more than ready to leave Washington in the lurch, as Charles Lee had done the year before. In Congress there was so strong a party opposed to Washington that to offend his unscrupulous rival while all the glamour of victory surrounded him would not be timely. The skill with which this young man, not yet one-and-twenty, wrested the troops from the reluctant Gates, peremptorily asserting Washington's claim, yet never allowing the affair to develop into a quarrel, was simply marvellous.

As a staff officer Hamilton was present at the battles of the Brandywine, Germantown, and Monmouth; he was Colonel Laurens's second in the duel between 
that officer and Charles Lee; and at West Point he was the first to receive and read the papers taken from André's stockings and containing the melancholy proofs of Arnold's treason. He saw much of André and of Mrs. Arnold, and his letters give a most touching description of the affair. Soon after this his connection with Washington's staff came abruptly to an end. On the I6th of February, I78I, as Washington was going up the stairs at his headquarters at New Windsor, he met Hamilton coming down and told him that he wished to speak to him. Hamilton, who was on his way downstairs to deliver an important order, replied that he would return in a moment. On his way back he was met by Lafayette, who accosted him on some pressing matter of business. In his impatience to return upstairs he cut Lafayette short in a manner which, as he says, but for their intimacy would have been more than abrupt. He was not aware of having consumed more than two minutes altogether, but when he reached the head of the staircase he found Washington waiting there, and these words were exchanged:

"Colonel Hamilton, you have kept me waiting at the head of the stairs these ten minutes. I must tell you, sir, you treat me with disrespect."

"I am not conscious of it, sir; but since you have thought it necessary to tell me so, we part."

"Very well, sir, if it be your choice."

And so they parted. At first sight the breaking of such an important relation on such a slight occasion seems silly, and Hamilton's reply to his commander childishly petulant. But Washington's temper was hasty. That he believed himself to have reproved his 
young friend unjustly was shown by his sending an aide to him a few moments afterward, with what was virtually an apology and a request that he would reconsider his decision. Hamilton, however, had for some time wished to leave the staff for a place in the line, and now that the matter had taken this shape he preferred to let it remain so. Any resentment he expressly disclaimed, and it does not appear that the cordial friendship between the two men was in the least disturbed by this little episode. Hamilton presently obtained the opportunity which he coveted, and in the Yorktown campaign commanded a body of light infantry in Lafayette's division, at the head of which he stormed one of the British redoubts with signal valour. This was the end of his military career. On his mission to General Gates he had become acquainted with Elizabeth, daughter of General Schuyler, and their marriage took place on the $14^{\text {th }}$ of December, I780. In the spring of $\mathrm{I} 782$, as soon as it became evident that the war was over, Hamilton removed to Albany, and in July was admitted to the bar.

Other business than law practice, however, came up to occupy his attention. We have seen how forcibly the weakness of the government and the need for revenue had been brought home to Washington's staff officer. He had pondered deeply on these subjects, and had already conceived the scheme of an alliance of interests between the federal government and the moneyed class of society. One of the instruments by which the alliance was to be effected was a national bank, which was to be a corporation in private hands, but to some extent supported and controlled by Con- 
gress. He also advocated extending the powers of the federal government and placing the departments of war and finance in the hands of individuals instead of committees. His views made a great impression upon Robert Morris, who was appointed in $\mathrm{I} 78 \mathrm{I}$ superintendent of finance. In December of that year the Bank of North America was established, and Hamilton must share with Robert and Gouverneur Morris the authorship of that scheme. About the time he entered the bar he was appointed continental receiver of taxes for the state of New York. In that capacity he visited the legislature at Poughkeepsie, had an earnest conference with a committee of both houses, and presently the legislature actually passed resolutions calling for a convention of all the states for the purpose of enlarging the powers of Congress, especially with regard to taxation. Nothing ever came of this action, but in view of the subsequent course of New York, it is remarkable that Hamilton's first attempt should have succeeded so well. But there can be little doubt that between $\mathrm{I} 782$ and $\mathrm{I} 788$ the politics of New York were somewhat corrupted by her custom-house. In the general confusion she found herself prospering at the expense of her neighbours, and the strength of the Anti-federalist or Clintonian party was naturally increased by that circumstance; it would have been so in any state.

In October, 1782, the New York legislature chose Hamilton as one of its delegates to Congress. There he first came into familiar contact with Madison, and met James Wilson, with others of less note; and there he witnessed some months of barren and almost purposeless wrangling which convinced him that 
nothing was to be hoped from any attempt at reform which should stop short with the mere amending of the confederation; it must be entirely superseded by a stronger government. On every proposal which looked toward amendment he took the affirmative and argued with his accustomed power that nothing was accomplished. This winter's experience doubtless increased his disgust at the jealousies and the perpetual jarring between the states. Hamilton's own position was peculiar in so far as he was not a native of any one of the states, and had from his first connection with public affairs felt more interest in the country as a whole than in any part of it. His attitude, therefore, was such as to enable him to move much more freely and directly toward the construction of a national government than any of his contemporaries. Another effect of so much fruitless discussion may well have been to confirm his distrust of popular government. For what an Athenian would have called the rule of the many-headed King Demos he never had much liking. He could see much more clearly than the men around him many of the things that were needed and the most efficient means for obtaining them; and there was in his temperament an impatience and an imperiousness that made him irk at the dulness of his fellow-creatures and the length of time required to set their common sense to work in the right direction. He was a devoted friend to free government; not, however, to that kind of free government in which the people rule, but the kind in which they are ruled by an upper class, with elaborate safeguards against the abuse of power. To such views Hamilton was predisposed by nature; his intimate experience of the 
contrast between Washington's efficiency and the inefficiency of Congress had done much to confirm them; his own winter of hard work in Congress no doubt confirmed them still more. Every man has the defects of his excellences, and this element of narrowness in Hamilton's view of popular government was closely related to the qualities that made him so preeminent as a constructive thinker.

One winter of such hopeless work was for the present enough for Hamilton. In 1783 he returned to the practice of law and began rising rapidly at the bar. Even in his professional practice he had an opportunity to figure as a defender of the federal government against the state sovereignty. Just as it was in later years with Daniel Webster, his first famous law case stood in a noticeable relation to his career as a statesman. Hamilton was honourably distinguished for his vigorous condemnation of the cruel and silly persecution to which the Tories, especially in New York, were subjected after the close of the war. His first great case, in 1784 , was one in which the treaty obligations of the United States to protect the Tories from further abuse came into conflict with a persecuting act which the New York legislature had lately passed against such people. There was then no federal Supreme Court, or any other federal court, in which such questions could be settled. The case was one which must begin and end in the state courts of New York, and its bearing upon the political question was rather implied than asserted. It was a case in which, if the state law were upheld, a poor widow would recover property of which the vicissitudes of war deprived her; but if the state law were set aside, a 
mass of spoliation would be prevented in comparison with which the widow's affair was the veriest trifle. Popular sympathy was wholly with the widow and against her Tory opponent, and in acting as counsel for the latter Hamilton showed such moral courage as had hardly been called for in any law case since John Adams and Josiah Quincy defended the British soldiers concerned in the so-called Boston Massacre. That he should have won his case against a hostile court, in such a moment of popular excitement; was hardly to be expected. That he did win it, and in so doing overturn the state law in question, was a marvellous feat, - the strongest proof one could wish of his unrivalled power as an advocate. The decision of the court was followed by a war of pamphlets in which Hamilton again won the day, and went far toward changing the public sentiment. At this moment there entered upon his life the ominous shadow of the duel, that social pest, which by and by, under other circumstances and at other hands, was to cut him off in the very prime of his powers and usefulness. A club of blatant pothouse politicians proposed to take turns in calling him out until some one of them should have the good fortune to kill him; but the wild scheme came to naught.

Two more years elapsed while Hamilton was engaged in professional work, and then Virginia, under the lead of Madison, called for a convention of all the states at Annapolis, to consider the feasibility of establishing a uniform system of commercial regulations for the whole country. Here Hamilton saw his opportunity, and succeeded in getting New York to appoint delegates, with himself among them. When the con- 
vention met in September, I 786, only five states were represented, so that the only thing worth while to do was to try again and call another convention. It was Hamilton who wrote the address calling for a convention at Philadelphia, to meet in the following May, to consider the best means of clothing the federal government with powers adequate for the maintenance of order and the preservation of the Union. It was high time for such work to be undertaken, for the whole country was falling under the sway of the lord of misrule. Congress was bankrupt, foreign nations were scoffing at us, Connecticut had barely escaped from war with Pennsylvania and New York from New Hampshire, there were riots and bloodshed in Vermont, Rhode Island seemed on the verge of civil war, Massachusetts was actually engaged in suppressing armed rebellion, Connecticut and New Jersey were threatening commercial non-intercourse with New York. Spain was defying us at the mouth of the Mississippi, and a party in Virginia was entertaining the idea of a separate Southern confederacy. Under such circumstances it was necessary to act quickly, and it was Hamilton's business to see that New York was represented in the convention. To that end he succeeded in getting elected to the legislature, and spent the winter in a hard fight against the party that was opposed to a clear union of the states. That party was very strong. At its head was the governor, George Clinton, who preferred to remain the most powerful citizen of New York rather than occupy a subordinate place under a national government in which his own state was not foremost. The policy of local high tariffs directed against the neighbouring states had been 
temporarily successful, although it was already threatening New York with a war. Though some of the most intelligent people in the state understood the shortsightedness of the governor's policy, the multitude were always ready to throw up their caps and shout, "Hurrah for Clinton!" It was this unreasoning popular support that made Clinton at that moment the most formidable enemy then living in the United States to all schemes and movements that tended toward a closer union. Here again the circumstances were such as naturally to strengthen Hamilton's hatred of democracy. Here was democracy confronting him with intent to thwart and prevent the work to which he had now come to consecrate his life.

This was a hot fight. At length Hamilton, with the valuable aid of Schuyler and the Livingstons, won a victory, such as it was. Delegates were indeed chosen, so that New York was not unrepresented in the convention, like Rhode Island. Hamilton was one of these delegates, so that he was to have a chance to express his views and make his influence felt. But every effort to obtain more than three delegates was voted down, and Hamilton's two colleagues, Robert Yates and John Lansing, were uncompromising Antifederalists, so that it was perfectly certain that he would never succeed in the convention in carrying the vote of New York for one single measure looking toward the fulfilment of the objects for which that convention had been called.

Thus hampered, the share which Hamilton took in the debates of the convention was a small one. He could only express his individual preferences, well knowing that as soon as it came to a vote his two colleagues 
would overrule him. To have disputed every point would simply have emphasized the fact that he did not really represent his own state, and would thus have impaired his usefulness. So he threw all his force into one great speech. Early in the proceedings, after various plans of government had been laid before the convention, he took the occasion to present his own view of the general subject. Only an outline of his speech, which took five hours in delivery, has been preserved. Gouverneur Morris said it was the most impressive speech he ever heard in his life. In the course of it Hamilton read his own carefully prepared plan, of which we need only notice the two cardinal features. First, he would have had the President and senators elected by persons possessed of a certain amount of landed property, and he would have had them hold office for life or during good behaviour. This would have created an aristocratic republic, as near to an elective monarchy with a life peerage as one could very well get. Secondly, he would have aimed a deathblow, not merely at state sovereignty, but at state rights, by giving the President the appointment of the several state governors, who were to have a veto on the acts of their legislatures. If such a measure as this had been adopted, the Union in all probability would not have lasted a dozen years. The position of a governor appointed by any power outside the state would have borne altogether too much likeness to the position of the royal governors before the Revolution. The will of the people, as expressed by the state legislature, would have been liable at any moment to be overruled by a governor who, whether a native of the state or not, would have owed his position to considerations which 
might be antagonistic to the policy of the state. The clashing between imperial and local interests might not have been so violent as before the Revolution, but there would have been so much to remind people of the old state of things that the new government would have been discredited from the start.

It seems clear, then, that in this suggestion Hamilton did not show his wonted sagacity. He failed to understand what was really sound and valuable in state rights, and this was not at all strange in a man who, having been born outside of the United States, was at this very moment contending against the extreme state sovereignty doctrines of New York and her narrow-minded governor.

Fortunately, however, there was not the slightest chance of Hamilton's extreme views prevailing in the convention, and this he knew as well as any one. His suggestions, it was said, were praised by everybody, but followed by no one. Presently urgent business called him home, and his two colleagues quit the convention in disgust, so that New York was left without representation there. Toward the close he returned to Philadelphia, and when the draft of the federal Constitution was completed, he made an eloquent speech, urging all the delegates to sign it. No man's ideas, he said, could be more remote from the plan than his were known to be; but was it possible for a true patriot to deliberate between anarchy and civil war, on the one side, and the chance of good to be expected from this plan, on the other? This was the spirit of the true statesman, and in this spirit he signed alone for New York.

The "Empire State" has had many illustrious citi- 
zens, but to none does she owe such a debt of gratitude as to Alexander Hamilton for inscribing her name on this immortal record. In the desperate struggle which followed, every inch of ground once gained counted as a victory; and it was much that when the Constitution was first published to the world the name of New York was attached to it.

In the ten months which followed the close of the convention we see Hamilton at the most interesting period of his life. Still buoyant with youthful energy, just finishing his thirty-first year, his rare flexibility of mind was now most strikingly illustrated. Like a wise statesman, when he could not get the whole loaf, he made the most that he could out of the half. His noble, disinterested patriotism, not content with leading him to sign a constitution of which he only half approved, now urged him to defend it with matchless ability in the papers which make up that immortal volume, the "Federalist." The Constitution, as finally adopted by the convention, was very far from being the work of any one man, but Madison's share in framing it had been very great, and it represented his theory of government much more nearly than Hamilton's. The thoroughness, however, with which Hamilton made the whole work his own, is well illustrated by the difficulty in deciding from internal evidence what parts of the "Federalist" were written by him and what parts by Madison. In the controversy which has been waged upon this question, it has been shown that we can seldom light upon such distinctive features of treatment and style as to lead to a sure conclusion. This shows how completely the two writers were for the moment at one, and it shows Hamilton's marvellous 
adaptability. It also illustrates one characteristic of his style. Had he been endowed with a gorgeous poetical imagination like Burke, or had he been a master of rhetoric in the same sense as Webster, there could never have been any difficulty in distinguishing between his writing and Madison's. But Hamilton's style was a direct appeal to man's reason; and the wonder of it was that he could accomplish by such a direct appeal what most men cannot accomplish without calling into play the various arts of the rhetorician. To make a bare statement of facts and conclusions in such a way that unwilling minds cannot choose but accept them is a rare gift indeed. But while this was Hamilton's secret, it was to some extent Madison's also. Though a much less brilliant man in many ways, in this one respect Madison approached Hamilton, though he did not quite equal him. Hence, as it seems to me, the general similarity of style throughout the disputed numbers of the "Federalist."

As the speeches in Xenophon's "Anabasis" give one a very brief opinion of the intelligence of the Greek soldiers to whom such arguments might even be supposed to be addressed, so the essays in the "Federalist" give one a very high opinion of the intelligence of our great-grandfathers. The American people have never received a higher compliment than in having had such a book addressed to them. That they deserved it was shown by the effect produced, and it is in this democratic appeal to the general intelligence that we get the pleasantest impression of Hamilton's power.

The most remarkable exhibition of it, however, was in the state convention at Poughkeepsie, in June and July, I 788 , for considering the question as to ratifying 
the federal Constitution. Ten of the thirteen states had now ratified it, or one more than the number necessary for putting it into operation. The laggards were New York, North Carolina, and Rhode Island. The latter state, isolated between her two stronger neighbours, might be left out of account for the moment, and so might North Carolina, for owing to the slavery compromises South Carolina had become intensely Federalist, a fact of cardinal importance in the history of the next thirty years. But as for New York, she could not for a moment be disregarded. Though not yet one of the greatest states, her position made her supremely important. It had been so in the days of Stuyvesant, and of Frontenac, and of Montcalm, and of Burgoyne; and just so it was in the days of George Clinton. If he could have carried his point, our federal Union, cut in twain by the Mohawk and Hudson valleys, would have had but a short life. That he did not carry it was mainly due to Hamilton's wonderful power of striking directly home at the sober reason of his fellow-men. It is not so very often that we see one man convince another by sheer argument. When passions and prejudices are enlisted, it is seldom that either side will budge an inch. The more they argue the more obstinate they grow, and if the affair gets settled, it is usually by some sort of compromise, in which each side tries to comfort itself with the belief that it has overreached the other. In the New York convention of 1788 there was no chance for compromise; the question as to ratifying the constitution must be answered with Yes or No; and if the vote had been taken at the beginning two-thirds of the members would have voted No. At the head of the Anti-feder- 
alist forces was Melanchthon Smith, an extremely able debater, no mean antagonist even for Hamilton. He must have been a man of rare candour, too, for after weeks of debate he owned himself convinced. The Clintonian ranks were thus fatally broken, and the decisive vote showed a narrow majority of three in favour of the Constitution. Seldom, indeed, has the human tongue won such a victory. It was the Waterloo of Anti-federalism. In the festivities that followed in the city of New York, when the emblematic federal ship - the ship of state-was drawn through the streets, it was with entire justice that the name of Hamilton was emblazoned upon her side.

A new chapter was now to begin in Hamilton's career. President Washington, in endeavouring to represent in his cabinet the nation rather than a party, selected Jefferson as his Secretary of State and Hamilton as his Secretary of the Treasury. Nothing but strife could come out of such relations between two such powerful and antagonistic natures. The dissensions between the two leaders and the great division between American parties arose gradually but rapidly, as Hamilton's bold, aggressive financial policy declared itself. It was a time when bold measures were needed. At home and abroad American credit was dead, because the Continental Congress had no power to tax the people and therefore could get no money to pay its debts. Now, under the new Constitution the House of Representatives could tax the people, and the problem for Hamilton was to suggest the best means of using this new, unfamiliar, and unpopular power, so as to obtain a steady revenue from the very start without arousing too much hostility. A preliminary part 
of the problem was to decide what was to be done with the mass of public debt already incurred. There were three kinds of such debt. First, there were the sums due to foreign governments for money lent to the United States for carrying on the War of Independence. Everybody, agreed that this class of debts must be paid to the uttermost farthing. Secondly, there were the debts due to American citizens who had invested their money in Continental securities. Hamilton's proposal that these should be paid in full, interest as well as principal, met with some opposition. In the chaos which had hitherto prevailed, such securities had fallen greatly in value, and the first glimmer of a better state of things showed that speculators had been buying them up in hopes of a rise. It was now argued that, by redeeming all such securities at their full value, the government would be benefiting the speculators rather than repaying the original investors. But Hamilton understood clearly that, with nations as with individuals, credit can be maintained only by paying one's debts in full, without asking what is going to become of the money. After some discussion this view prevailed in Congress.

Over the third class of debts there was a fierce dispute. These were the debts owed by the several state governments to private citizens. Much distress had ensued from the inability of the states to discharge these obligations. The discontent in Massachusetts, which had culminated in Shays's rebellion, was partly traceable to such a cause. On every side creditors were clamorous. Nothing would go so far toward strengthening the new government as to allay this agitation and awaken a feeling of confidence in busi- 
ness circles. To this end Hamilton came forth with a measure of startling boldness. He proposed that the federal government should assume all these state debts and pay them, principal and interest!

This was no doubt a master stroke of policy. It was one of the most important steps taken by Washington's administration toward setting the new government fairly upon its feet. Had it not been for this act of assumption state creditors would have been so jealous of national creditors, there would have been such a jumble of clashing interests, that no steady financial policy could have been carried out, and people would soon have been impatiently asking wherein was the new government any better than the old. But by this act of assumption all public creditors, from Maine to Georgia, were at once made national creditors, and all immediately began to feel a personal interest in strengthening the federal government. This measure of Hamilton's was as shrewd as his idea of having governors appointed by the President had been foolish. That, if adopted, would have sought to drive men; this was an attempt to draw them.

It was Hamilton's proposal for the assumption of the state debts that originated the first great division between political parties under the Constitution. It also partly drew the line of division between the Northern and the Southern states. In the debates on the ratification of the Constitution it did not appear that the desire for a more perfect union was any stronger at the North than at the South. Virginia was scarcely more afraid of centralization than Massachusetts, and Rhode Island was even more backward in ratifying than North Carolina. But the assumption 
question tended to unite the Northern states in favour of a centralizing policy and the Southern states in opposition to the same. This was because the great majority of the public creditors were to be found among Northern capitalists. Hamilton's policy appealed directly to their selfish interests, but it did not so appeal to the Southern planters. One of the chief reasons for Virginia's hesitancy in accepting the Constitution had been her fear that the commercial North might acquire such a majority in Congress as to enable it to tyrannize over the agricultural South. The Virginians now denounced the assumption policy as unconstitutional, and Hamilton in self-defence was obliged to formulate what is known as the doctrine of "implied powers." He gave a liberal interpretation to that clause in the Constitution (Art I., Sect. viii., p. I8) which authorized Congress "to make all laws which shall be necessary and proper for carrying into execution" such powers as are explicitly vested in the government of the United States. The opponents of a strong government, on the other hand, insisted upon a strict and narrow interpretation of that clause; and thus arose that profound antagonism between "strict constructionists" and "loose constructionists" which has run through the entire political history of the last hundred years. As a rule the Republican party of Jefferson, with its lineal successor, the Democratic party from Jackson to Cleveland, has advocated strict construction; while loose construction has characterized the Federalist party of Hamilton, with its later representatives, - the National Republican party of Quincy Adams, the Clay and Webster wing of the Whig party, and the Republicans of the present day. 
This general rule, however, has been seriously complicated by the fact that the same party is apt to entertain very different views when in power from those which it entertains when in opposition. The tendency of the party in possession of the government is to interpret its powers liberally, while the party in opposition seeks to restrict them. So generally has this been the case in American history that it would be difficult to lay down any theory of the subject which any statesman has consistently applied on all occasions. Hamilton, however, was always a loose constructionist. As we have seen, the Constitution was never nearly centralizing enough to suit him, and the more powers that could be given to the general government, the better he was satisfied.

The division between North and South on the assumption policy was not complete, for here, as on most questions previous to 1820 , South Carolina was on the Federalist side. In this particular instance her interests were like those of some of the Northern states, for she had a heavy war debt, of which the proposed measure would relieve her. Even with this assistance, however, the bitter fight over assumption would have ended in defeat for Hamilton, had not another fight then raging afforded an opportunity for compromise. A new city was about to be designed and reared as the Federal capital of the United States, and the question was where should it be situated. The Northern members of Congress were determined that it should not be farther south than the Delaware River; the Southern members were equally resolved that it should not be farther north than the Potomac; the result was the first, and in some respects the 
greatest, instance of "log-rolling" known to American history. The Northern advocates of assumption carried their point by yielding to the Southerners in the matter of the capital. Congress assumed over $\$ 20,000,000$ of state debts, and the city of Washington was built upon the bank of the Potomac.

This was a great victory for Hamilton, for the Federalist party, and for the United States as a nation. It certainly required a pretty liberal interpretation of the Constitution to justify Congress in assuming these debts, but if it had not been done it is very doubtful if the Union could long have been held together. We must always be grateful to Hamilton for his daring and sagacious policy, yet at the same time we must acknowledge that the opposition was animated by a sound and wholesome feeling. Every day showed more clearly that Hamilton's aim was to insure the stability of the government through a firm alliance with capitalists, and the fear was natural that such a policy, if not held in check, might end in transforming the government into a plutocracy, - that is to say, a government in which political power is monopolized by rich men, and employed in furthering their selfish interests without regard to the general welfare of the people. Those who expressed such a fear were more prescient than their Federalist adversaries believed them to be; for now after the lapse of a hundred years the gravest danger that threatens us is precisely such a plutocracy! It has been one of our national misfortunes that for three-quarters of a century the mere maintenance of the Union seemed to call for theories which when put into operation are very far from making a government that is in the fullest sense "of the 
people, by the people, and for the people." The only party that ever extricated itself from the dilemma, and stood at one and the same time unflinchingly for the Union and against paternal government in every form, was the party of Jackson and Van Buren between I 830 and I 845 . But with Hamilton paternal government was desirable, not only as a means of strengthening the Union, but as an end in itself. He believed that a part of the people ought to make laws for the whole. Having now provided for the complete assumption of all debts, domestic and foreign, state and federal, by the United States, the next question was how to raise the money for discharging them. The new government was regarded with distrust by many people. It was feared that the burden of federal taxation would be intolerable. Men already found it hard to pay taxes to their town, their county, and their state; how could they endure the addition of a fourth tax to the list? There was but one way to deal with this difficulty. Probably a general system of direct taxation would not have been endured. It was accordingly necessary to depend almost entirely upon custom-house duties. This gentle, insidious method enables vast sums to be taken from people's pockets without their so much as suspecting it. It raises prices, that is all ; and the dulness of the human mind may be safely counted upon, so that when a tax is wrapped up in the extra fifty cents charged for a yard of cloth, it is so effectually hidden that most people do not know it is there. Custom-house duties were accordingly levied, and the foreign trade of the United States was already so considerable that a large revenue was at once realized from this source. To win added favour to this 
policy Hamilton advocated a tariff for what is called protection as well as for revenue, although his argument fell very short of meeting the exorbitant requirements of the pampered industries of our own time. Here, as in his assumption policy, it was Hamilton's aim to ally the government with powerful class interests. He saw the vast natural resources of the country for manufactures, he knew that flourishing industries must presently spring up, and he understood how to enlist their selfish interests in defence of a liberal construction of the powers of government. A remarkable instance of his foresight was exhibited some years afterward in the case of Daniel Webster, who, although in principle an advocate of free trade, nevertheless succumbed to the protectionists and allied himself with them, in order to save the principle of loose construction and thus leave the general government with powers adequate to the paramount purpose of preserving the Union.

"The necessity of relying chiefly upon custom-house duties was strikingly illustrated by the reception given in one part of the country to a direct federal tax. Upon distilled liquors Hamilton thought it right to lay a direct excise; but it was with some difficulty that he succeeded in getting the measure through Congress, and it was no sooner enacted than riotous protests began to come from the mountain districts of North Carolina, Virginia, and Pennsylvania. The highest tax laid on whiskey was only twenty-five cents per gallon, but it led to such serious disturbances in western Pennsylvania that in the summer of 1794 President Washington raised an army of I 5,000 men to deal with them. It was the design of the malcon- 
tents to capture the federal garrison at Pittsburg, and then to secede from the Union, together with the western counties of Virginia and North Carolina, and form an independent state of which the corner-stone should be free whiskey. But Washington's action was so prompt and his force so overwhelming that the rebellion suddenly collapsed without bloodshed. Thus the strength of the government was most happily asserted and Hamilton's financial policy sustained in all particulars.

The completion of Hamilton's general scheme was the establishment of a national bank, in which the government was to own a certain portion of the stock, and which was to make certain stated loans to the government. This was another feature of the alliance between the government and the moneyed classes. Like the other kindred measures, it was attacked as unconstitutional, and as in the other cases the objection was met by asserting the loose constructionist theory of the Constitution. Hamilton's financial policy was thus in the widest sense a political policy. In these methods of obtaining revenue and regulating commerce were laid the foundations of the whole theory of government upon which our federal Union was built up. Their immediate effect in reviving the national credit was marvellous. They met with most hearty support in the Northern states, while in the purely agricultural state of Virginia they were regarded with distrust, and under the leadership of Jefferson and Madison there was developed a powerful opposition which was soon to prove wholesome as a restraint upon the excesses into which pure federalism was betrayed. 
It was the French Revolution and the consequent war between France and Great Britain that so reacted upon American politics as to bring about the downfall of the Federalist party and hurry to an untimely end the career of its illustrious founder. During the last decade of the eighteenth century the whole civilized world seemed bitten with the fierce malady that was raging in France. Semel insanivimus omnes. In America the excitement soon reached such a point as to subordinate all questions of domestic policy; and Hamilton's opponents, foiled in their attempts to defeat his financial measures, were not unwilling to shift the scene of battle to the questions connected with our foreign relations. It was the aim of the French revolutionary party to drag the United States into war with Great Britain, but the only sound policy for the Americans was that of strict neutrality. The insolence of the British court made this a very difficult course to pursue, and probably it would have been impossible had not the French in their demands upon us shown equal insolence. The pendulum of popular feeling in America, under the stimulus of alternate insults from London and from Paris, vibrated to and fro. The Federalists, as friends of strong government, saw in the French convulsions nothing but the orgies of a crazy mob; while on the other hand the Republicans had a keener appreciation of the vileness of the despotism that was being swept away and the wholesome nature of the reforms that were being effected amid all the horrors and bloodshed. Under the influence of such feelings the antagonism between Hamilton and Jefferson grew into a bitter personal feud, and the quarrels in the cabinet were so fierce that Wash- 
ington once exclaimed he would rather be in his grave than sit and listen to them. Never, perhaps, did Washington's strength of character seem more colossal than in the steadiness with which he pursued his course amid that wild confusion.

The first outburst of popular wrath was against Great Britain on the occasion of the Jay treaty in 1794. The treaty was called a base surrender to the British, and Hamilton was stoned while attempting to defend it in a public meeting in New York. Washington's personal authority, more than anything else, carried the treaty and averted war with Great Britain. At that moment the Republican opposition was at its height, and scurrilous newspapers heaped anathemas upon Washington, calling him the "stepfather of his country." But as the Jay treaty enraged the French and made them more abusive than ever, the zeal of the Republican sympathizers began to cool rapidly. When in 1798 it appeared that Prince Talleyrand was trying to extort blackmail from the United States, popular wrath in America was turned against France, the war cry was raised, "Millions for defence, not one cent for tribute," the Republicans were struck dumb, and the Federalists seemed to be riding on the top of the tide. In a moment of over-confidence the latter now ventured upon a step which soon led to their downfall. In their eagerness to keep out intriguing foreigners and curb the license of the newspapers, they carried through Congress the famous alien and sedition laws. Through Hamilton's influence these acts were somewhat softened in passing, but as passed they were palpably in violation of the Constitution, and infringed so outrageously upon freedom of speech and of the 
press as to seem to justify all that had been said by Republicans as to the dangerous aims and tendencies of the Federalist party.

During the two years preceding the election of 1800 the Federalists steadily lost ground, and the very war fever which had for a moment so powerfully aided them now gave rise to dissensions within their own ranks. Between Hamilton and John Adams there had been for some time a feeling of jealousy and distrust, not based upon any serious difference of policy, but simply upon the fact that one party was not large enough to hold two men of such aggressive and masterful temperament. As is apt to be the case with mere personal differences, in which no question of principle is involved, it was marked by pettiness and silliness on both sides. As in those days the electoral tickets did not distinguish between the candidates for the presidency and the vice-presidency, it was possible to have such a thing as a tie between the two candidates of the same party; it was even possible that through some accident or trick the person intended by the party for the second place might get more electoral votes than his companion and thus be elected over him. In 1796 the Federalist candidates were John Adams and Thomas Pinckney, and the advice given privately by Hamilton to his friends was such as would, if not thwarted, have made Pinckney President and Adams Vice-president. Hamilton's conduct on this occasion was certainly 'wanting in frankness, and when Adams discovered it he naturally felt ill used. The relations between the two were made more uncomfortable by the fact that Hamilton, although now in private life, seemed to have more influence with Adams's cabinet 
than Adams himself. In 1798 the President saw a chance to retaliate. A provisional army was to be raised in view of the expected war with France, and Washington accepted the chief command on condition that he might choose his principal officers. With this understanding he named as his three major-generals Hamilton, Cotesworth Pinckney, and Knox. President Adams tried to reverse this order, on the ground that in the revolutionary army Knox's rank was higher than Hamilton's. A quarrel ensued which involved the whole Federalist party, and was ended only when Washington declared that unless his wishes were respected he should resign. Before such a stroke as this even Adams's obstinacy must give way, and he was placed in the humiliating attitude of a man who has not only tried to do a mean thing, but has failed.

If John Adams, however, could be weak, he could also be very strong, and his course during the year I 799 was nothing less than heroic. France was so far affected by the warlike preparations of the United States as to begin taking informal steps toward a reconciliation, and Adams, who knew that war ought if possible to be avoided, resolved to meet her halfway. In spite of the protests of leading Federalists, including part of his own cabinet, he sent envoys to France, who in the following year succeeded in making a treaty with Napoleon as First Consul. In taking this step Adams knew that he was breaking up his own party on the eve of a presidential election; he knew that he was thus in all probability ruining his own chances for that second term which he desired most intensely; but he acted with a single eye to the 
welfare of the country, and in all American history it would be hard to point to a nobler act.

The ensuing year, 1800 , was one of dire political confusion. In the spring election in New York Hamilton contended unsuccessfully against the wiles of Aaron Burr; a Republican legislature was chosen, and in the autumn this legislature would of course choose Republican electors for President. Political passion now so far prevailed with Hamilton as to lead him to propose to Governor Jay to call an extra session of the old legislature and give the choice of presidential electors to districts. This would divide the presidential vote of New York and really defeat the will of the people as just expressed. Jay refused to lend himself to such a scheme. That Hamilton should ever have entertained it shows how far he was blinded by the dread of what might follow if Jefferson and the Republicans should get control of the national government.

Yet in spite of this dread he took the very rash step of writing a pamphlet attacking Adams, and advising Federalists to vote for him only as a less dangerous candidate than Jefferson. This pamphlet was intended only for private circulation, but Burr contrived to get hold of it, and its publication helped the Republicans.

Even with all this dissension among their antagonists, the Republican victory of $\mathrm{I} 800$ was a narrow one. Adams obtained sixty-five electoral votes. The Republican candidates, Jefferson and Burr, each obtained seventy-three, and it was left for the House of Representatives to decide which of the two should be President. Nobody had the slightest doubt that the choice of the party was Jefferson, and that Burr was 
intended to be Vice-president, but the situation offered an opportunity for intrigue. Many leading Federalists were so bent upon defeating their arch-enemy, Jefferson, that they were ready to aid in raising Burr above him. But political passion could not so far confuse Hamilton's sense of right and wrong as to lead him to inflict such a calamity upon the country. His great influence prevented the wicked and dangerous scheme on the part of the Federalists, and Jefferson became President.

In a most tragic and painful way the shadow of the duel was now thrown across Hamilton's career. His eldest son, Philip, aged eighteen, a noble and highspirited boy, of most brilliant promise, had just been graduated at Columbia. In the summer of $\mathrm{I} 8 \mathrm{O}$ I this young man was bitterly incensed at some foul aspersions on his father which were let fall in a public speech by a political enemy. Meeting this unscrupulous speaker some few evenings afterward in a box at the theatre, high words ensued, and a challenge was given. The duel took place on the ledge below Weehawken Heights, which was then the customary place for such affairs. Young Hamilton fell mortally wounded at the first fire, and was carried home to die. As one reads of the agonized father, on hearing the first alarming tidings, running to summon the doctor and fainting on the way, it comes home to one's heart today with a sense of personal affliction. The student of history becomes inured to scenes of woe, but it is hard to be reconciled to such things as the shocking death of this noble boy.

It was to be the father's turn next. The unprincipled intrigues of Burr with the Federalists had ruined his chances of advancement in the Republican party. 
His only hope seemed to lie in further intrigues with the Federalists. The wonderful success of Jefferson's administration was winning fresh supporters daily from the opposite ranks, and the Federalist minority was fast becoming factious and unscrupulous. It was believed by some that Timothy Pickering and others in New England were meditating secession from the Union and the establishment of a Northern confederacy, to which New York, and perhaps New Jersey and Pennsylvania, might be added. Burr was a vain and shallow dreamer. As governor of New York he might rise to be president of a Northern confederacy. At any rate it was worth while to be governor of New York, and Burr, while still Vice-president of the United States, became a candidate for that position in 1804 . Hamilton had earned the gratitude of his fellowcountrymen by thwarting Burr's schemes in I8OI. He now thwarted them again. Burr failed of election and vowed revenge. His political prospects were already well-nigh ruined; to a wretch like him there was some satisfaction in killing the man who had stood in his way. The affair was cool and deliberate. He practised firing at a target, while in a crafty correspondence he wound his vile meshes around his enemy, and at length confronted him with a challenge. Hamilton seems to have accepted it because he felt that circumstances might still call for him to play a leading part in national affairs, and that to decline a challenge might impair his usefulness. The meeting took place on the I Ith of July, I804, at that ill-fated spot under Weehawken Heights. Hamilton fell at the first fire, and was carried home, to die the next day. The excitement in New York was intense. Vast 
crowds surrounded the bulletins which told of the ebbing of his life, and their sobs and tears were mingled with fierce oaths and threats against the slayer. As the news slowly spread through the country, the tongue of political enmity was silenced, and the mourning was like that called forth in after years by the murder of Abraham Lincoln. It has been thought that the deep and lasting impression produced by this affair had much to do with the discredit into which the practice of duelling speedily fell throughout the Northern states.

When Alexander Hamilton's life was thus cut short, he was only in his eight-and-fortieth year. Could he have attained such a great age as his rival, John Adams, he might have witnessed the Mexican War and the Wilmot Proviso. Without reaching extreme old age he might have listened to Webster's reply to Hayne, and felt his heart warm at Jackson's autocratic and decisive announcement that the federal Union must be preserved. One may wonder what his political course would have been had he lived longer; but it seems clear that he would soon have parted company with the Federalists. He had already taken the initial step in breaking with them by approving Jefferson's purchase of Louisiana. The narrow sectional policy of Pickering and the New England Federalists was already distasteful to him. As the Republican party became more and more national, he would have found himself inclining toward it as John Adams did, and perhaps might even have come, like Adams in later years, to recognize the merits and virtues of the great man whose name had once seemed to him to typify anarchy and misrule, - 
Thomas Jefferson. Such mellowing influence does wide and long experience of life sometimes have, when one can witness great changes in the situation of affairs, that we may be sure it would not have been without its effect upon Alexander Hamilton. When the new division of parties came, after I 825 , there can hardly be a doubt that he would have found his place by the side of Webster and John Quincy Adams.

At the time of his death he was inclined to gloomy views of the political future, for he lacked that serene and patient faith in the slow progressiveness of average humanity which was the strong point in Jefferson. His disposition was to force the human plant and to trim and prune it, and when he saw other methods winning favour, it made him despondent. He was in his last days thinking of abandoning practical politics and writing a laborious scientific treatise on the history and philosophy of civil government. Such a book from the principal author of the "Federalist" could hardly have failed to be a great and useful book, whatever theories it might have propounded. But since we have it not, we may well be content with the "Federalist" itself, a literary monument great enough for any man and any nation. And as for Hamilton, his quick insight, his boldness of initiative, and his rare constructive genius have stamped his personality so deeply upon American history that, in spite of his untimely death, his career has for this and for future generations all the interest that belongs to a complete and well-rounded tale. 
THOMAS JEFFERSON

THE CONSERVATIVE REFORMER 



\section{THOMAS JEFFERSON}

\section{THE CONSERVATIVE REFORMER}

IN the development of English civilization on its political side there have been few agencies more potent than those represented by the independent yeomanry and the country squire. In the history of such a country as France, until very recent times, the small rural freeholder scarcely plays a part. There under the old régime we see the powerful nobleman in his grim château, surrounded by villages of peasantry holding their property by a servile tenure. The nobleman is exempt from taxation, his children are all nobles and share in this exemption, so that they constitute a class quite distinct from the common people and having but little sympathy with them. The only middle class is to be found in the large walled towns, whose burghers have acquired from the sovereign sundry privileges and immunities in exchange, perhaps, for money furnished to aid him in putting down rebellious vassals. Representative assemblies are weak and their means of curbing the crown very limited, so that early in the seventeenth century they fall into disuse; and as the crown gradually conquers its vassals and annexes their domains, the result is at length an extremely centralized and oppressive despotism in which the upper classes are supported in 
luxurious idleness by taxes wrung from a groaning peasantry. The state of things becomes so bad that a radical reform is possible only at the cost of a frightful paroxysm of anarchy; and the traditions of personal independence are so completely lost that a century of earnest struggle has not yet sufficed to regain them. As a little American girl observed the other day, as the net result of her first impressions of Paris, "Every man here has to have some other man to see that he does what he ought to do."

Now in the history of England perhaps the most striking of all the many points of contrast with French history consists in the position of the rural landholder. The greatest proprietor in the country, though almost sure to be a peer, does not belong to a different class from the common people: his children are not peers, and only one of them is likely to become so, except perhaps for personal merit. There is no more promising career for the younger son than is offered by a chance to represent the voters of his county in the House of Commons, and thus there has never been a sharp division between classes, as there used to be in France. Noble families have always paid their full share of the taxes. The small tenants have in many cases been freeholders, and since the fourteenth century the higher kinds of servile tenures, such as copyhold, have practically ceased to be servile. The higher grades of copyholders and the smaller freeholders constitute that class of yeomanry that has counted for so much in history. Of old these small freeholders were often known as "franklins," and one of their American descendants, winning an immortal name, has illustrated the many virtues, the boldness and thrift, the upright- 
ness and canny tact, which has made them such a power in the world. Of somewhat higher dignity than the mere freeholder was the "lord of the manor," or country squire with tenants under him. He might be the son of a peer, or he might be a yeoman who had risen in life. This rural middle-class had many points of contact on the one hand with the nobility and on the other hand with the burghers of the large towns. They were all used from time immemorial to carrying on public business and settling questions of general interest by means of local representative assemblies. There was far less antagonism between town and country than on the Continent, and when it became necessary to curb the sovereign it was comparatively easy for the middle class in town and country to join hands with part of the nobility for that purpose.

We can thus understand why the earl and his castle have not furnished popular tradition with the themes of such blood-curdling legends as have surrounded the count and his château. The old English yeoman, with his yew-tree bow and clothyard shaft, was the most independent of mortals, and nothing could exceed his pitying contempt of the whole array of armoured knights and starveling peasantry that he scattered in headlong flight at Poitiers and Navarrete. His lord of the manor was not so much the taskmaster of his tenants as their leader and representative. A sturdy and thrifty race were these old English squires. Today perhaps it was to call out their archers and march against the invading Scot; to-morrow it was to sit in Parliament with hats drawn over their knitted brows and put into dutiful but ominous phrases some stern demand for a redress of wrongs. Age after age of such 
discipline made them capable managers of affairs, keenly alive to the bearings of political questions, and fierce sticklers for local rights. There never existed a class of men better fitted for laying the foundations of a nation in which a broad and liberal democracy should be found compatible with ingrained respect for parliamentary methods and constitutional checks.

Now it was this middle class of squires and yeomanry that furnished the best part of colonial society in Virginia, as it furnished pretty much the whole of colonial society in New England. An urban middle class of merchants and artisans came in greater numbers to New England than to Virginia, and the Southern colony, besides its negroes, received a very low class of population in the indented white servants, who seem to have been the progenitors of the modern "white trash." But the characteristic society - that which has made the histories of New England and of Virginia what they are - had the same origin in both cases. There was also in both cases a principle of selection at work, although not so early in Virginia as in New England. As the latter country was chiefly settled between 1629 and I640, the years when Charles I. was reigning without a Parliament, so the former received the most valuable portion of its settlers during the Commonwealth, when the son of that unfortunate monarch was off upon his travels. Men who leave their country for conscience' sake are apt to be picked men for ability and character, no matter what side they may have espoused. Our politics may be those of Samuel Adams, but we must admit that the Hutchinson type of character is a valuable one to have in the community. Of the gallant cavaliers who fought 
for King Charles there were many who no more approved of his crooked methods and despotic aims than Hutchinson approved of the Stamp Act. A proper combination of circumstances was all that was required to bring their children into active alliance with the children of the Puritans. Most of the great leaders that Virginia gave to the American Revolution were descended from men who had drawn sword against Oliver Cromwell; and a powerful set of men they were. Virginia has always known how to produce great leaders. The short-lived Southern Confederacy would have been much shorter lived but for Lee, Johnston, and Jackson; and the cause of the Union would have fared much harder but for the invincible Thomas.

Colonial life in Virginia departed less than in New England from the contemporary type of rural life in the mother country. Agriculture in New England throve best with small farms cultivated by their owners, and this developed the type of yeomanry, while the ecclesiastical organization tended to concentrate the population into self-governing village communities. Agriculture in Virginia seemed to thrive best with great estates cultivated by gangs of labourers, and this prevented the growth of villages. The Virginia planter occupied a position somewhat like that of the English country squire. He had extensive estates to superintend and county interests to look after. He was surrounded by dependents, mostly slaves indeed, and in this aspect the divergence from English custom was great and injurious; still Virginia slavery was of a mild type. In his House of Burgesses the planter had a parliament, and in the royal governor, representing a distant sovereign, there was a source of antago- 
nism and distrust requiring him to keep his faculties perpetually alert, and to remember all the legal maxims by which the liberties of Englishmen had been defended since the days of Bracton and Fortescue.

It was into this community that Thomas Jefferson was born on the I $3^{\text {th }}$ of April, I 743. His first American ancestor on the father's side had come to Virginia among the very earliest settlers, and was a member of the assembly of 1619 , the first legislative body of Englishmen that ever met on this side of the ocean. The Jeffersons belonged to the class of yeomanry. Thomas's father was a man of colossal stature and strength, which the son inherited. Like Washington, he was a land surveyor and familiar with the ways of Indians. His farm, on which wheat was cultivated as well as tobacco, by about thirty slaves, was situated on what was then the western frontier, near the junction of the Rivanna River with the James. $\mathrm{He}$ was a justice of the peace, colonel of the county militia, and for some time member of the House of Burgesses. He died suddenly in 1757 , perhaps from exposure in the arduous frontier campaigning of that year.

Thomas's mother was Jane Randolph, daughter of one of the most patrician families in Virginia. From her he is said to have inherited his extreme tenderness of nature and aversion to strife, as well as his love of music. From his father he derived a strong taste for mathematics and the constructive arts, a punctilious accuracy in all matters of business, a hatred of ceremony, and a dislike to have other people wait upon him. Thomas, when full grown, was six feet and two inches in height, lithe and sinewy, erect and alert, with reddish hair and bright hazel eyes. His features were 
by no means handsome, but the expression of his face was attractive. As a daring horseman, a dead shot with a rifle, and a skilful player of the violin, he was remarkable even among Virginians. Until he entered William and Mary College, at the age of seventeen, he had never seen a village of as many as twenty houses; but since his ninth year he had pored over Latin and Greek, and a box of mathematical instruments and a table of logarithms were his constant companions. In college he worked with furious energy, and besides his classical and scientific studies he kept up an extensive reading in English, French, and Italian. He used to keep a clock in his bedroom, and get up and go to work as soon as it was light enough to see what time it was. After leaving college he studied law under one of the best of teachers, George Wythe, and in two of the best of text-books, Bracton and Coke. He had a keen appreciation of the Toryism of Blackstone, and some suspicion of the mistaken standpoint from which that charming writer viewed the development of the English constitution, as has been shown in our day, with such. wealth of learning, by Freeman and Stubbs. $\mathrm{He}$ also gave much attention to Montesquieu and Locke, and the Parliamentary debates. In 1767 he began the practice of law, and in 1769 was elected to the House cf Burgesses. In 1772 he was married to the blooming widow of Bathurst Skelton. His first notable political act was in I774, on the occasion of the convention held in August for choosing delegates to the first Continental Congress. Being prevented by illness from attending the convention, he drew up a series of instructions such as he hoped the convention would 
give to the delegates. This paper, when read in the convention, was so much liked that it was printed as a pamphlet under the title of "A Summary View of the Rights of British America." In this paper Jefferson set forth a doctrine which was very popular with the Americans at that time, and deservedly so, bècause it gave expression to the view of their relations with Great Britain upon which they had always implicitly acted. Jefferson held that "the relation between Great Britain and the colonies was exactly the same as that of England and Scotland" between 1603 and I607, "and the same as her present relations with Hanover, having the same executive chief, but no other necessary connection." The Americans acknowledged the headship of the king, but not the authority of Parliament, and when that body undertook to legislate for Americans, it was simply a case of "one free and independent legislature" presuming "to suspend the powers of another, as free and independent as itself." James Otis had said things not unlike this a dozen years before, when he argued that the supremacy of the colonial assembly in Massachusetts was as indisputable and as sacred as that of the Parliament in Great Britain; and similar arguments had been used by Samuel Adams and others. But Jefferson's terse way of stating the case had a decided savour of revolution about it. His pamphlet went through ever so many editions in England; its arguments were incorporated into the resolutions adopted by the Continental Congress; and in the following spring Jefferson was himself elected a delegate to that great Revolutionary body. He was then thirty-two years old, and the only delegates younger than himself were John 
Jay, aged thirty, and Edward Rutledge, aged twentysix. Four days before he took his seat the battle of Bunker Hill was fought, and when the news reached Philadelphia he was appointed on a committee with Dickinson and others for drawing up a manifesto justifying to the world the course of the Americans. The manifesto as published contained only a few words of his, but among them were the following: "We mean not to dissolve that union which has so long and so happily subsisted between us, and which we sincerely wish to see restored. Necessity has not yet driven us into that desperate measure." Wonderfully eloquent was that little word "yet"! The threat of all that was to happen next year was latent in it. The current of feeling was moving rapidly just then. Two months later Jefferson wrote: "There is not in the British empire a man who more cordially loves a union with Great Britain than I do. But by the God that made me I will cease to exist before I yield to a connection on such terms as the British Parliament proposes; and in this I think I speak the sentiments of America." Observe the historical accuracy of this wording. It was not a question of throwing off a yoke, but of refusing to yield to a connection on newfangled and degrading terms. The American colonies had never been under a yoke, but they had maintained a connection with Great Britain in which their legislative independence had until within the last ten years been virtually recognized. Now they were asked to surrender that legislative independence and come under the yoke of the British Parliament, and this, said Jefferson, they would never consent to do. The American Revolution was essentially conservative. It 
was fought not so much to gain new liberties as to preserve old ones. It was the British in this case that were the innovators, and the Americans that were the conservatives. This is the true historical light in which to study our Revolution, and so this largeminded young student of Bracton and Coke understood it. Because in later years Jefferson came to be the head of a party which sympathized with revolutionary France, there has come into existence a legendary view of him as a sort of French doctrinaire politician and disciple of Rousseau. Nothing could be more grotesquely absurd. Jefferson was broad enough to learn lessons from France, but he was no Frenchman in his politics; and we shall not understand him until we see in him simply the earnest but cool-headed representative of the rural English freeholders that won Magna Charta and overthrew the usurpations of the Stuarts.

It was chiefly in drawing up state papers that Jefferson excelled in Congress, and herein he played a part for the whole country like that which Samuel Adams had played in the legislature of Massachusetts in the earlier scenes of the Revolution. As an orator Jefferson never figured at all. With all his remarkable strength and vigour his voice was weak and husky, so that he found it hard to speak in public. He had besides a nervous shrinking from hearing himself talk on the spur of the moment about things which he knew he could so much better deal with sitting at his desk. And then he was utterly wanting in combativeness. However he might evoke contention by his writings, its actual presence was something from which his deliberate, introspective, and delicately poised 
nature shrank. He was in no wise lacking in moral courage, but his sympathies were so broad and tender that he could not breathe freely in an atmosphere of strife.

For such a nature the pen, rather than the tongue, is the ready instrument. As a wielder of that weapon which is mightier than the sword Jefferson was now to win such a place as would have made him immortal, even had he done no more. In June, I 776, as Richard Henry Lee, who had moved the Declaration of Independence, was called home to Virginia by the illness of his wife, Jefferson was appointed chairman of the committee for drawing up the declaration. The draft as made by him, with two or three slight changes interlined by Franklin and John Adams, was substantially adopted by Congress. There were no interpolations worth mentioning, but there were a few omissions, and the most important of these was the passage which denounced George III. for upholding the slave-trade. The antislavery party in Virginia was quite strong at that time. In 1769 the legislature had enacted a law prohibiting the further importation of negroes to be sold into slavery, but at the king's command the governor had vetoed this wholesome act. Jefferson made this the occasion of a denunciation of slavery and the slavetrade, but inasmuch as New England shipmasters combined with South Carolina planters in carrying on this " execrable commerce," Congress remembered that people who live in glass houses should not begin to throw stones, and the clause was struck out.

Some expressions in the Declaration of Independence are often quoted in illustration of Jefferson's Gallicism. It begins with a series of generaliza- 
tions: "We hold these truths to be self-evident, that all men are created equal, that they are endowed by their Creator with certain unalienable rights, that among these are Life, Liberty, and the pursuit of Happiness. That to secure these rights, Governments are instituted among men, deriving their just powers from the consent of the governed," etc. In these sentences we may plainly see the result of French teaching. It would be very difficult to find in the files of the House of Commons any such abstract announcements of "self-evident truths." The traditional English squire would appeal, not to speculation, but to precedent. He would defend his rights, not as the natural rights of men, but as the chartered and prescriptive rights of Englishmen. This was because the English squire had a goodly body of prescriptive rights which were worth defending, but the French peasant, who had nothing but prescriptive wrongs, was obliged to fall back upon the natural rights of man. In attempting to generalize about liberty and government, the French philosophers of that day soon got beyond their depth, as was to have been expected. Such problems cannot be solved by abstract reason, but the attempt to rest the doctrines of civil liberty upon a broad theoretical basis was praiseworthy. Jefferson was always a philosopher as well as a statesman, and he was quite capable of learning from Voltaire and Montesquieu, Rousseau and Diderot, who were then the most suggestive and stimulating writers in the world. It pleased him to give a neat little philosophical turn to the beginning of his great document, but after this exordium he goes on to the end in the practical tone of the English squire. The king 
is arraigned at the bar of public opinion as a violator of chartered rights, a sovereign who by breaking the law has forfeited the allegiance of his American subjects. There is something very happy in the skill with which any explicit mention of Parliament is avoided. " $\mathrm{He}$ has combined with otHers to subject us to a jurisdiction foreign to our constitution and unacknowledged by our laws; giving his assent to their acts of pretended legislation," etc. It is only in this way that allusion was made to Parliament, and it would have been impossible to state with more consummate skill the American view of the position based upon solid American precedent. In every clause is wrapped up a genuine historic pearl. There is not one that appears as an inference from the philosophic preamble, which indeed might have been omitted without altering the practical effect of the document. Nothing could more clearly show what a skin-deep affair Jefferson's Gallicism really was.

In the summer of I 776 Jefferson was reëlected to the Continental Congress, but declined to serve. It was with him as with many other public men at that time. Important changes were going on in the several state constitutions, which made the services of the ablest men needed at home. In Virginia there was a great work to be done, and Jefferson went into it with wonderful vigour, ably assisted by his old teacher, George Wythe, and by Colonel George Mason and the youthful James Madison. It was on the 7 th of October, I 776, that Jefferson again took his seat in the Virginia legislature. One week from that day he reported a bill abolishing the whole system of entail. That ancient abuse was deeply rooted in the affections of 
many of the old families, but popular feeling must have been strongly aroused against it, for Jefferson's bill was passed within three weeks. All entailed estates at once became estates in fee simple, and could be bought and sold or attached for debt like other property. It was a sweeping reform and won for Jefferson the vindictive hatred of many of the aristocrats, some of whom were cruel enough to point to the death of his only son as a divine judgment which he had brought down upon himself by his impious disregard of the sacred rights of family. But the reformer did not stop here. He next assailed primogeniture, and presently overthrew it. At the same time, as chairman of a committee for revising the laws, he showed, in one important respect, a wise conservatism. Against the advice of his able colleague, Edmund Pendleton, he insisted upon retaining the letter of the old laws wherever possible, because the precise meaning of every phrase had been determined by decisions of the courts, and to introduce new terminology is always to open a fresh source of litigation. With all this caution he did very much toward simplifying the code. Here again we see, not the a priori French iconoclast, but the practical and liberal English squire. Other reforms, proposed by Jefferson and ultimately carried out, were the limitation of the death penalty to the two crimes of murder and treason, and the abolition of imprisonment for debt. He tried to introduce public schools like those of New England, and to have a public library established in Richmond; but the state of society in Virginia was not sufficiently advanced in this direction to support him. He was an earnest advocate of the abolition of slavery, but he 
realized that there was no hope of carrying through the legislature any measures to that end. He did, however, in 1778 bring in a bill prohibiting the further importation of slaves into Virginia, and carried it without serious opposition.

The relations between Church and State also claimed his attention. The Episcopal Church was then established by law in Virginia, and dissenters were taxed to support it. Besides there were many heavy penalties attached to nonconformity; a man convicted of heresy might be deprived of the custody of his children. Jefferson's own views of the relations between government and religion are expressed in the following remarkable passage from his "Notes on Virginia." Opinion, he says, is something with which government has no business to meddle; it is quite beyond its legitimate province. "It does me no injury for my neighbour to say there are twenty gods, or no God. It neither picks my pocket nor breaks my leg. . . . It is error alone which needs the support of government. Truth can stand by itself. Subject opinion to coercion, and whom will you make your inquisitors? Fallible men, governed by bad passions, by private as well as public reasons. And why subject it to coercion? Difference of opinion is advantageous to religion. The several sects perform the office of censor morum over each other. Is uniformity attainable? Millions of innocent men, women, and children, since the introduction of Christianity, have been burnt, tortured, fined, imprisoned; yet we have not advanced one inch toward uniformity. Let us reflect that the earth is inhabited by thousands of millions of people; that these profess probably a thousand different sys- 
tems of religion; that ours is but one of that thousand; that if there be but one right, and ours that one, we should wish to see the nine hundred and ninety-nine wandering sects gathered into the fold of truth. But against such a majority we cannot effect this by force. Reason and persuasion are the only practicable instruments. To make way for these, free inquiry must be indulged; and how can we wish others to indulge it, while we refuse it ourselves?" These few pithy sentences have had no little influence upon American history. For half a century they furnished the arguments for the liberal-minded men who, by dint of persistent effort, succeeded in finally divorcing Church from State in all parts of our Union. For holding such views Jefferson was regarded by many people as an infidel; in our time he would be more likely to be classed as a liberal Christian. The general sentiment of the churches has made remarkable progress toward his position, though it would be too much to say that it has yet fully reached it. In most matters Jefferson's face was set toward the future; in this he was clearly in advance of his age, and it was a notable instance of his power over men that after only nine years of strenuous debate his views should have become incorporated in the legislation of Virginia. In winning the victory he was greatly aided by the disfavour into which the Established Church had fallen in that state because of the lowered character of its clergy, and the extreme Toryism of their politics. The credit for the victory, moreover, must be divided between Jefferson and Madison, whose assistance, always very valuable, was here especially powerful.

In these years Jefferson's industry was prodigious. 
His work on legislative committees was enough to tax the stoutest nerves, yet he found time for his gardening and his scientific studies, and thanked the Lord for the thoroughness of the early training which enabled him to solace himself in the intervals of hard work by reading Homer in the original. Such strong natures find relaxation and rest in what to ordinary mortals is painful drudgery. His Greek and his mathematics were a relief to him, and of course he worked all the better for them, as well as for his farming and his hunting and his violin. His tastes were all wholesome, pure, and refining; his motives were disinterested and lofty; and under that sweet, placid surface his energy was like a consuming fire. Seldom has a man so stamped his personality upon a community as Jefferson in these few years upon Virginia, and thus indirectly and in manifold ramifications upon the federal nation in which Virginia was for nearly half a century more to be the leading state. The code of Virginia, when he had done with it, might almost have been called the Code Jefferson. Pity that his influence, reënforced by that of Washington and Madison, Wythe and Mason, could not then have removed her from the list of slave states! Every Virginian today must confess that that was a pity. But Jefferson did all that it was in human strength to do. To the end of his days he mourned over negro slavery, and saw in it the rock upon which the ship of state might break into pieces and founder. "I tremble for my country," said he, "when I think of the negro and know that God is just." All the agony that creased its furrows upon the brow of Abraham Lincoln was foretold in those solemn words. 
The work done by Jefferson in Virginia was to some extent imitated in other states, not only in its general spirit but often in details. One step in his warfare with the old Tory families intrenched about Williamsburg was the removal of the state capital to the village of Richmond, which he accomplished in spite of bitter opposition. For Virginia this turned out to be a wise policy, but it is curious to see how generally it was imitated, apparently through a dread and a jealousy felt by the bucolic democracy toward cities and city people. Thus our modern capitals are not New York, but Albany; not Philadelphia, but Harrisburg; not Milwaukee, but Madison; not St. Louis, but Jefferson City; not New Orleans, but Baton Rouge, and so on through the majority of the states. In like manner, in 1786 , the Shays party wished to remove the government of Massachusetts from Boston to some inland village.

Another measure which Jefferson introduced in Virginia, in 1776 , and which has been generally imitated, was the provision for admitting foreigners to citizenship after a residence of two years and a declaration of intention to live in the state. This policy, when first introduced, was unquestionably sound, and has contributed powerfully to the rapid growth of the United States in population and in wealth. It has brought, moreover, to a far greater extent than is supposed in much of the current talk upon this subject, an excellent class of immigrants containing the more energetic and adventuresome elements in the middle and lower strata of European society. Circumstances, nevertheless, that could not have been foreseen a century ago have surrounded it with dangers. 
Cheapness and ease of travel have gone far toward making our country the dumping-ground for a much worse class of immigrants from all quarters, so that it becomes a serious question whether we can assimilate them and teach them American political ideas with sufficient rapidity. Jefferson's plan of easy naturalization was admirable in 1776 , but in our time it stands in need of amendment and restriction.

In 1779 Jefferson was chosen governor of Virginia, but he declined a renomination in $\mathrm{I} 78 \mathrm{I}$, and returned to the legislature. It was while he was governor that Lord Cornwallis invaded the state; the legislature, which for security had assembled at Charlottesville, was broken up in one of Tarleton's raids, and Jefferson barely escaped capture in his own house at Monticello. His political enemies afterward twitted him with running away, but I never heard of any man except Don Diego Garcia, enshrined in the inimitable pages of Cervantes, who undertook to fight single-handed against a whole army. In I 782 Mrs. Jefferson died. after having been for some years in very poor health. For many weeks after this bereavement Jefferson's keen interest in life was quenched. He could do no work, but spent his days in wandering through the woods absorbed in grief. Of his six children, only two daughters lived to grow up, but he had long ago brought home the six orphan children of his brotherin-law, Dabney Carr, and reared them with tenderest care. In his busiest and most anxious times he never failed to devote part of his attention, most conscientiously and methodically, to their education.

In 1783 he was returned to Congress in time to take part in ratifying the treaty of peace. He assisted 
Gouverneur Morris in devising our decimal currency, and suggested the dollar as the unit. He handed to Congress the deed of Virginia ceding the Northwestern Territory to the United States; and he drew up the Ordinance of $\mathrm{I} 784$, in which he endeavoured to introduce the principle of prohibiting all extension of slavery into the national domain, the principle upon which the present Republican party was founded just seventy years later. If Jefferson could have established this principle in 1784 , it would have altered the whole course of American history. As it is, much credit must be given to his initiative in leading to the result which in the Ordinance of 1787 prohibited slavery north of the Ohio River. In May, I 784, Jefferson's legislative work, so noble and so fruitful, came to an end. He left Congress and was appointed commissioner to aid Franklin and John Adams in negotiating commercial treaties with European nations. He arrived in Paris in August, I 784. In the following spring the commission was broken up, Adams was appointed minister to Great Britain, Franklin came home, and Jefferson was appointed minister to France. It has been said that "his first diplomatic move was a bon mot, and therefore in France a success. "You replace M. Franklin, I hear,' remarked the Count de Vergennes at an interview. 'I succeed him, your Excellency,' he replied promptly; ' "no one can replace him.'"

The author of the Declaration of Independence was well received in Paris. His book entitled, "Notes on Virginia," published about this time, was widely read and greatly admired. He soon became a kind of oracle for literary men and political theorizers to con-

1 Rosenthal, "America and France," p. 128. 
sult. To-day it is M. Démeunier who seeks help in preparing his articles on political economy for the "Encyclopédie Méthodique." To-morrow it is M. Soulés who is writing in four volumes a history of the American war and comes for advice. Counsel on still more pressing subjects was soon called for. The four years of Jefferson's sojourn in Paris were of surpassing interest, for they ended in the outbreak of the great Revolution. Jefferson's intimacy with Lafayette brought him much into the society of the men with whom he most sympathized, the reasonable and moderate reformers, such as Barnave, Rabant de Saint Étienne, Duport, Mounier, and others, who were often gathered around his hospitable dinner table. When the States General were assembled, he used to go every day to Versailles to watch the proceedings. On the 9th of July, I789, the British ambassador, the Duke of Dorset, wrote to Mr. Pitt that " Mr. Jefferson, the American minister at this court, has been a great deal consulted by the principal leaders of the Tiers État; and I have great reason to think that it was owing to his advice that that order called itself L'Assemblee Nationale." However this may be, there is no doubt that his advice was often sought. The most notable instance was when the Archbishop of Bordeaux, as chairman of a committee of the assembly for sketching the plan of a constitution for France, went so far as to invite him "to attend and assist at their deliberations." But Jefferson did not regard such action as becoming in a foreign minister, and accordingly he declined the invitation. In September, I789, before the furious phase of the Revolution had begun, he returned to America. 
The experience of these four years, aided by the general soundness of his political philosophy, enabled Jefferson to take a much more just view of the French Revolution than was taken by Englishmen of nearly all parties and by the Federalists in America. In its earlier stages the Whigs in England and almost everybody in America viewed the French Revolution with earnest sympathy; but when its fierce excesses came there was a violent reaction. Every one remembers how Burke, in his "Letters on a Regicide Peace," quite lost his head and raved. He could think of no better name for France than "cannibal castle," and wanted the revolutionary party summarily annihilated by an unrelenting policy of blood and iron. Such a reaction of feeling was natural enough. It seized upon the Federalists in America, and led such men as Hamilton to entertain absurd fears of the wild orgies of spoliation likely to ensue upon the victory of democracy in our country. The Federalists' view has survived down to our own time. In talking about the French Revolution people are apt to think only of the guillotine and its innocent victims, the saintlike Princess Elizabeth, the sprightly Madame Roland, Vergniaud, the brilliant orator, Malesherbes, the noble statesman, Lavoisier, the great chemist, André Chenier, the sweet poet, and so many others. In contemplating such sad cases it is too easy to forget the ineffable horrors, the pestilent foulness, of the old régime that was forever swept away, the enlightened and wholesome legislation that began in 1789 , and the rapid and powerful inoculation of the peoples of Europe with ideas that have since borne fruit in a restored Hungary, a renovated Germany and Italy, 
and increased comfort and happiness everywhere. It is too easy to forget that the atrocities of the Reign of Terror were the result of a temporary destruction of confidence among the members of the community, and that for this destruction of confidence the royalist émigrés, in seeking foreign military aid against their own country, were chiefly to blame. There can be no doubt that Jefferson, without approving the excesses of the Jacobins, understood the purport of events in France more correctly and estimated them more fairly than most of his American contemporaries. Of course this gave his political enemies a chance to call him a Jacobin, and has led those people of our own time to whom he is little more than a name to suppose that he obtained his theory of the government from Rousseau!

When Jefferson came home, in the autumn of 1789 , it was with the intention of soon returning to France to watch the progress of events; but when he arrived at Monticello, two days before Christmas, he found awaiting him an invitation from President Washington to the position of Secretary of State, and after some hesitation, being strongly urged by Washington and Madison, he accepted it. In March, I790, he took his place in the cabinet; during the preceding year it had been temporarily occupied by John Jay, whom Washington was about to make chief justice. As the most crying need of the new government was revenue, the work of organization had been carried on mainly by Hamilton as Secretary of the Treasury.

It has often been said that Washington, in choosing for the chief places in his cabinet two men so antagonistic to each other as Hamilton and Jefferson, was 
actuated by a desire to represent both parties and have a non-partisan government. On all sides Washington has been praised for this breadth of view, although it has sometimes been suggested that it was not characterized by his customary sagacity. It seems to me that this statement is wanting in historical accuracy, as it overlooks the fact that it was during Washington's administration, and not before it, that the definitive divisions between political parties grew up. It is true that Jefferson represented the type of opinions likely to prevail among the agricultural societies of the Southern states, while Hamilton represented the type of opinions likely to prevail among the commercial and manufacturing centres in the Northern states; but it is hardly correct to say that in 1789 these two men belonged to opposite political parties. The earliest division of American parties on a national scale began in the autumn of 1787 , when the federal Constitution was submitted to the people of the thirteen states for their approval. Then the friends of the Constitution were known as Federalists, and its enemies were called Anti-federalists. At that time Hamilton and Madison were foremost among the Federalists, while George Clinton and Patrick Henry were the foremost Anti-federalists. Samuel Adams has sometimes been spoken of as an Anti-federalist, but this is utterly and grossly inaccurate. Samuel Adams was slow in coming to a final decision, but when he made up his mind, it was in favour of the Constitution with such amendments as to be equivalent to a bill of rights, - such amendments as the first ten, which were soon afterward annexed to that instrument. When he decided in 
this way, his vast influence secured the ratification of the Constitution in Massachusetts by a very narrow majority. But for this attitude of Samuel Adams, Massachusetts would probably have rejected the Constitution, and that would have thrown everything back into chaos. During that momentous year, I 788, Jefferson was in France. What would have been his attitude if he had been at home and taken part in the Virginia convention? Unquestionably it would have been like that of Samuel Adams, for he says as much in his letters. He declared that he was much more a Federalist than an Anti-federalist, and the only faults he had to find with the Constitution were that it did not include a bill of rights, and that it did not provide against the indefinite reëligibility of the President, and thus prevent the presidency from lapsing into something like an elective monarchy. The first of those faults was soon corrected by the first ten amendments, which made a very effective bill of rights; the second was corrected by the precedent set by Washington and confirmed by Jefferson himself, in refusing to serve as President after two terms. It is thus evident that Jefferson, on his return to America, was practically a Federalist, as party lines were at that moment drawn.

But during Washington's administration the Federalists, led by Hamilton, having been given an inch by these state conventions that grudgingly ratified the Constitution, were naturally inclined, in the enthusiasm of their triumph, to claim an ell. The swiftly and radically centralizing measures of Hamilton soon carried the Federalists onward to a new position, so that those who agreed with them in 1789 had come to 
dissent from them in I793. It was thus in Washington's first administration that the seeds of all party differences hereafter to bear fruit in America were sown and sedulously nurtured. All American history has since run along the lines marked out by the antagonism between Jefferson and Hamilton. Our history is sometimes charged with lack of picturesqueness because it does not deal with the belted knight and the moated grange. But to one who considers the moral import of events, it is hard to see how anything can be more picturesque than the spectacle of these two giant antagonists, contending for political measures which were so profoundly to affect the lives of millions of human beings yet unborn. Coleridge once said, with as fair an approximation to truth as is likely to be reached in such sweeping statements, that in philosophy all men must be Aristotelians or Platonists. So it may be said that in American politics all men must be disciples either of Jefferson or of Hamilton. But these two statesmen represented principles that go beyond the limits of American history, principles that have found their application in the history of all countries and will continue to do so. Sometimes a broad comparison helps our understanding of particular cases. Indeed, our understanding of particular cases cannot fail to be helped by a broad comparison, if it is correctly made. Suppose, then, we compare for a moment the general drift of American history with that of British history. We are tolerably familiar with the differences between Liberals and Tories in the mother country. Let us see if we can compare the two great American parties with these, and decide which are the Liberals and which the 
Tories; and in doing this, let us divest ourselves for the moment of any prejudices which we may be in the habit of cherishing against either Liberals or Tories.

In England the chief characteristic of the Tory party has been its support of measures which tend to strengthen the crown and the aristocracy, and to enlarge and tighten the control exercised by the community over its individual members. The chief characteristic of the Liberal party has been its support of measures which tend to weaken the crown and the aristocracy, and to diminish and relax the control exercised by the community over its individual members. In all times and countries there has been such a division between parties, and in the nature of things it is the only sound and abiding principle of division. Ephemeral parties rise and fall over special questions of temporary importance, but this grand division endureth forever. Whereever there are communities of men, a certain portion of the community is marked off, in one way or another, to exercise authority over the whole and perform the various functions of government. The question always is how much authority shall this governing portion of the community be allowed to exercise, to how great an extent shall it be permitted to interfere with private affairs, to take people's money in the shape of taxes, whether direct or indirect, and in other ways to curb or restrict the freedom of individuals. All people agree that government must have some such powers, or else human society would be resolved into a chaos in which every man's hand would be raised against every other man. The political question is as to how 
much power government shall be permitted to exercise. Where shall the line be drawn beyond which the governing body shall not be allowed to go? This has been the fundamental question among all peoples in all lands, and it is the various answers to this question that have made all the differences in the success or the failure of different phases of civilization, - all the differences between the American citizen and the Asiatic coolie. We might thus take any nation that has ever existed for comparison with the United States, but we choose to take England, because there the will of the people has in all ages been able to assert itself. In countries where the voice of the people has been for a long time silenced, as in France under the old régime and in Russia, we naturally find parties coming up, like the Jacobins and the Anarchists, who would fain destroy all government and send us back to savagery; for in politics as well as in physics it may be said that action and reaction are equal and in opposite directions. But in England, just because the people have always been able to find their voice and use it, things have proceeded normally, in a quiet and slow development, like the unfolding of a flower; and so the differences between parties have never assumed a radically explosive form, but have taken the shape with which we are familiar as the differences between Liberals and Tories.

Now if we compare parties in America with parties in England, unquestionably the Jeffersonians correspond to the Liberals and the Hamiltonians to the Tories. It is, on the whole, the former who wish to restrict, and the latter who wish to enlarge, the powers 
of government. But this is an incomplete view of the matter. In England, for the last three centuries, political progress has consisted in limiting more and more the power of the crown and in admitting a larger and larger proportion of the people to a share in the government, and as the Tories have generally resisted these progressive measures, they have come to be somewhat discredited in the eyes of Americans. It is not my purpose, however, to attach any stigma to the followers of Hamilton, to the Federalists of 1800 , to the Whigs of 1840 , or to the Republicans of 1880 , in comparing them to the Tories. Not only has Toryism its uses in all ages of English history, but there was once a time when it was desirable to strengthen the crown, to increase the powers of the central government, and to subordinate the local governments as represented by the great vassals. That was the time when the English nationality was in process of formation, when the chief desideratum was to get a united and orderly England. In the eleventh and twelfth centuries it was a good thing to have such masterful kings as William the Conqueror, and Henry I., and Henry II. Even so late as the fifteenth century there was a very good side to the overthrow of the old baronage and the tightening of the grip of government under Henry VII. National unity is something that no people can afford to dispense with, for the alternative is chaos.

Now during the past hundred years the American nationality has been in process of formation, and it has been desirable to keep the central government strong enough to preserve the Union. That has, indeed, been the paramount necessity, and therefore 
the Hamiltonian theory of strong government has been of great value. We could not have got along without it. But it is a theory that needs to be applied with care and held in check with a curb rein. Otherwise it is sure to end in class legislation and plutocracy, and the reaction shows itself in labour agitation, strikes, and anarchical doctrines among the classes of people that feel themselves in some way deprived of their fair share in the good things of life.

In 1798 the Tory character of Hamiltonian federalism showed itself with crude frankness in the alien and sedition acts. At that time, as an indirect result of the feud between Hamilton and Adams, Jefferson had become Vice-president under a Federalist President. His protest against the abominable alien and sedition acts was uttered in the famous resolutions of Kentucky and Virginia, which seemed to tread dangerously near the confines of nullification. To avoid repetition I shall reserve what I have to say about these resolutions for my lecture on Madison. ${ }^{1}$ By I 800 the lines between the party which could enact the alien and sedition laws and the party which could approve the Virginia resolutions had become so sharply drawn that the presidential canvass was as fierce as in 1860 , or in 1876 , or in 1884 . Just as a good many people believed some years ago that the election of Mr. Cleveland meant the assumption of the rebel war debt, the undoing of the work of reconstruction, the instantaneous overthrow of the tariff,

${ }^{1}$ In this affair both the Hamiltonian and the Jeffersonian parties showed their weak sides. Against the excesses of a federalism which had lost its temper, the protest of republicanism was so energetic as to savour, for the moment, of political disintegration. 
and all manner of vague horror, so in 1800 the Federalists believed that the election of Mr. Jefferson meant the dissolution of the Union and the importation into America of all the monstrous notions of French Jacobinism. And just as after the election of 1876 some good people were so afraid of what Mr. Tilden might do that they were ready to sanction the shabby trick that kept him out of the place to which he had been chosen, so after the election of 1800 there were worthy people whose ideas of right and wrong became so confused that, rather than see the great and pure statesman, Thomas Jefferson, in the White House, they were ready to surrender the government to the tender mercies of such a scoundrel as Aaron Burr. It is wonderful how men lose their heads at such times. One would suppose that they were electing, not a constitutional magistrate, but, shall we say, a Russian Czar? No, for not even a czar can go far in working changes in government at his own sweet will. They seem rather to argue as if a President were like the king in a fairy tale, with unlimited capacity for evil. New England clergymen entertained a grotesque conception of Jefferson as a French atheist, and I have heard my grandmother tell how old ladies in Connecticut, at the news of his election, hid their family Bibles because it was supposed that his very first official act, perhaps even before announcing his cabinet, would be to issue a ukase ordering all copies of the sacred volume throughout the country to be seized and burned.

When people get into such a state of mind the only thing that can cure them is an object lesson. Mr. Cleveland's administration, human and fallible, 
but upright and able, has lately furnished us with such an object lesson. In the first eight years of this century the presence of Mr. Jefferson at the head of the government educated the American people in a similar way, but far more potently in that especially plastic and formative time. As a political leader we have hardly seen his equal. He had not the kind of lofty pugnacity which enabled Hutchinson to win victories in the teeth of popular prejudice and clamour, but he had that sympathetic insight into the thoughts and wishes of plain common people which Samuel Adams had, and for the want of which Hutchinson's career, in spite of his great powers and his noble character, was ruined.

A man of such sympathetic insight into the popular mind - a faculty in which Hamilton was almost as lacking as Hutchinson-was just the man that was needed at the head of our government in the first decade of the nineteenth century. Jefferson was needed at the helm in 1800 as much as Hamilton was needed in I790. He never could have done the work of Hamilton or of Madison. They were men of rare constructive genius; he was not. But when the first work of construction had been done and the government fairly set to work, Jefferson was just the man to carry it along quietly and smoothly until its success passed into a tradition and was thus assured. If he had been the French inconoclast that the Federalists supposed him to be, he could not have achieved any such results. But his career in the presidency, like his earlier career, shows him, not as a Danton, but as a Walpole. Instead of the general overturning which the Federalists had dreaded, the 
administration quietly followed the lines which Hamilton had laid down. In other words, it was in the hands of a constitutional magistrate who acquiesced in the decision of such questions by the will of the people. Moreover, as now wielding the administration and feeling the practical merits of Hamilton's measures, Jefferson was no longer so ready to condemn them. In the most important act of his presidency he deserted his strict constructionist theories and ventured upon an exercise of power as bold as Hamilton's assumption of state debts. Napoleon had lately acquired from Spain the vast territory between the Mississippi River and the crest of the Rocky Mountains; on the eve of war with England, he knew that this territory was an extremely vulnerable spot in his empire, and he was very glad to surrender it for hard cash. Accordingly President Jefferson bought it, and thus at a cost of $\$ 15,000,000$ more than doubled the area of the United States and gave to our nation its imperial dimensions. The Constitution had not provided for any such startling exercise of power. Probably the federal convention had not so much as thought of such a thing. What is more, this acquisition of territory reopened the question as to slavery, which the framers of the Constitution thought they had closed by their compromises. By and by the question was to arise as to what was to be done about slavery in states formed from the Louisiana territory, - a question to be settled only by civil war and the abolition of slavery altogether. In Jefferson's time no such result was dreamed of. The desirableness of ousting European influence from the mouth of the Mississippi River was very great, and 
the purchase was so generally approved that Jefferson abandoned his half-formed purpose of asking Congress to propose a constitutional amendment to justify him. Perhaps it was not needed. A quarter of a century later Chief Justice Marshall laid down the doctrine that "the Constitution conferred absolutely on the government of the Union the power of making war and of making treaties; consequently that government possesses the power of acquiring territory either by conquest or by treaty." ${ }^{1}$ In the time of Jefferson's presidency this would have been called loose construction. To the general approval of the Louisiana purchase there was one exception. In New England some people feared that in so huge a nation as this portended, their own corner of the country would be reduced to insignificance. The uneasiness continued until after the second war with England. In I 8 I I Josiah Quincy, afterward president of Harvard, declared in a fervent speech in the House of Representatives, that if the state of Louisiana, the first beyond the great river, should be admitted into the Union, it would be high time for the New England states to secede and form a separate confederacy.

With Jefferson's strong faith in the teachableness of the great mass of people we naturally associate universal suffrage, for his influence went largely in this direction. We often hear people say that the experiment of universal suffrage is a failure, that it simply

${ }^{1}$ Extract from the opinion of Chief Justice John Marshall, p. 542, I Peters (Sup. Court U. S.) Rep., The American Ins. Co. et al. v. Carter, January term, I828. The case was argued by Mr. Ogden for appellants, Mr. Whipple and Mr. Webster for Carter. This is all that appears in the decision touching the power to acquire territory. 
results in the sway of demagogues who marshal at the polls their hordes of bribed or petted followers. This is no doubt very bad. It is a serious danger against which we must provide. But do these objectors ever stop to think how much worse it would be if the demagogue, instead of marshalling his creatures at the polls, were able to stand up and inflame their passions with the cry that in this country they have no vote, no share in making the laws, that they are kept out of their just dues by an upper class of rich men who can make the laws? If your hod-carrier was sulking for the want of a vote, he would be ten times more dangerous than any so-called friend of labour can now make him. As it is, his vote does not teach him much, because of his dull mind and narrow experience, but after all, it gives him the feeling that he is of some account in the world, that his individuality is to some extent respected; and this is unquestionably one of the most powerful and conservative safeguards of American civilization. In point of fact, our political freedom and our social welfare are to-day in infinitely greater peril from Pennsylvania's iron-masters and the owners of silver mines in Nevada than from all the ignorant foreigners that have flocked to us from Europe. Our legacy of danger for this generation was bequeathed us by Hamilton, not by Jefferson.

The American people took Jefferson into their hearts as they have never taken any other statesman until Lincoln in these latter days. His influence endured in his green old age at Monticello, the favoured spot where in the early days, when American independence had hardly been thought of, he used to sit under the trees with his brilliant young friend and 
brother-in-law, Dabney Carr, and chat and dream over theories of government and power over men and the ways in which it asserted itself. The first term of his presidency was serene, because England and France were just at that moment at peace, and we were not called upon to take part in their quarrel. As candidate for a second term he simply swept the country. There was no one in 1804 who dreaded Jefferson. In the election of that year he had 162 electoral votes, while his Federalist opponent, Cotesworth Pinckney, had only 14. Jefferson's influence had become so great because he had absorbed all the strength of his adversary. He had not approved of Hamilton's acts, but he knew how to adopt them and appropriate them, just as Hamilton had adopted and appropriated Madison's theory of the Constitution. Here again if I may say it once more - we see, not the French iconoclast, but the English squire.

Jefferson died on the $4^{\text {th }}$ of July, 1826, at Monticello, just half a century after the promulgation of that Declaration of Independence which he had written, and John Adams had most powerfully defended in the Continental Congress. In the bitter political strife between I 795 and I800 Jefferson and Adams had become enemies; but in later years the enmity had subsided as old party strife had subsided. Jefferson had carried the day. He had lived long enough to see the fruition of his work, to see the American people in full sympathy with him, and to win back the esteem of the great statesman, John Adams, from whom he had been so long divided. Could there have been a nobler triumph for this strong and sweet nature? On the $4^{\text {th }}$ of July, $\cdot 1826$, at one 
o'clock midday, he quietly passed away, serene in death as in all his life. Three hours before on that same day, at his home in Massachusetts, John Adams died, and just before the last breath left him the memories of the grand old times when Massachusetts and Virginia stood together and built up this Union flitted across his mind, and he murmured, "Thomas Jefferson still lives." 

JAMES MADISON

THE CONSTRUCTIVE STATESMAN 



\section{V \\ JAMES MADISON}

THE CONSTRUCTIVE STATESMAN

IN the work of constructing our national government and putting it into operation there were five men distinguished above all others. In an especial sense they deserve to be called the five founders of the American Union. Naming them chronologically, in the order of the times at which the influence of each was most powerfully felt, they come as follows: George Washington, James Madison, Alexander Hamilton, Thomas Jefferson, and John Marshall. But for Washington it is very doubtful if independence would have been won, and it is probable that the federal Constitution would not have been adopted. The fact that the experiment of the new government could be tried under his guidance made quite enough votes for it to turn the scales in its favour. His weight of authority was also needed to secure the adoption of Hamilton's measures and to prevent the half-formed nation from being drawn into the vortex of European war. As for Madison, he was the constructive thinker who played the foremost part among the men who made the Constitution, besides contributing powerfully with tongue and pen to the arguments which secured its ratification. In this work of advocacy Hamilton reënforced and surpassed Madison, and then in the work of prac- 
tical construction, of setting the new government into operation, Hamilton, with his financial measures, took the lead. But the boldness of Hamilton's policy alarmed many people. There was a widespread fear that the government would develop into some kind of a despotism, and this dread seemed presently to be justified by the alien and sedition laws. Other people were equally afraid of democracy, because in France democracy was overturning society and setting up the guillotine. There was such a sad want of public confidence among the American people between I 790 and I 800 , that an outbreak of civil war at the end of that period would not have been at all strange. To create the needed confidence, to show the doubters and scoffers on the one hand that the new government was really a government of the people, by the people, and for the people, and on the other hand that such a government can be as orderly and conservative as any other, - this was the noble work of Jefferson, and it was in his presidency that the sentiment of loyalty to the Union may be said to have taken root in the hearts of the people. One thing more was needed, and that was a large, coherent body of judicial decisions establishing the scope and purport of the Constitution, so as to give adequate powers to the national government, while still protecting state rights. It was that prince of jurists, John Marshall, who, as chief justice of the United States for one-third of a century, thus finished the glorious work.

Of these five great men the names of Madison and Marshall are much less often upon people's lips than the others'. The work in which they excelled was not of a kind that appeals to the popular imagination, and 
personally they were less picturesque figures than the other three. Especially is this true of Madison. There are many people who do not realize the importance of his career or the greatness of his powers. Mr. Goldwin Smith, some time ago, in an article in the Nineteenth Century spoke of Madison as a respectable gentleman of moderate ability, whose most memorable act was allowing himself to be bullied and badgered into making war against Great Britain contrary to his own better judgment. This is very much as if one should say of Sir Isaac Newton that he was a corpulent old gentleman, remembered chiefly for having been master of the mint and author of a rather absurd book on the prophecies of the Old Testament. Mr. Smith evidently did not realize that he was speaking of a political philosopher worthy to be ranked with Montesquieu and Locke.

Some of the reasons for this partial eclipse of Madison's reputation will appear as we proceed. At present we may call attention to the prevailing tendency to associate historic events with some one commanding personality, and to forget all the rest. This is a labour-saving process, but it distorts our view of history. Hamilton was a much more picturesque personage than Madison, and so there has been an unconscious disposition to accredit him with Madison's work as well as his own. There are people who know enough about some things to write respectable books, and still know so little about American history as to suppose that our federal Constitution was substantially the work of Hamilton. One often sees remarks in print in which this gross error is implied, if not asserted. In point of fact Hamilton had almost nothing to do with the 
actual work of making the Constitution. If you consult a set of Hamilton's writings, you observe that one volume is the "Federalist." That is quite right, but it need not make us forget that one-third of the volume was written by Madison. The work of Hamilton was in itself so great that there is no need for a Hamilton legend in which the attributes and achievements of other heroes are added to his own. Let us now pass in review some points in Madison's career.

His earliest paternal ancestor in Virginia seems to have been John Madison, who in I653 took out a patent for land between the North and York rivers on Chesapeake Bay. There was a Captain Isaac Madison in Virginia as early as 1623 , but his relationship to John is matter of doubt. John's grandson, Ambrose Madison, married Frances Taylor, one of whose brothers, named Zachary, was grandfather of President Zachary Taylor. The eldest child of Ambrose and Frances was James Madison, who was married in I 749 to Nelly Conway, of Port Conway. Their eldest child, James, was born at Port Conway on the I6th of March, I 75 I, so that he was eight years younger than Jefferson and six years older than Hamilton. He was the first of twelve children. His ancestors, as he says himself in a note furnished to my old friend Dr. Lyman Draper in I834, "were not among the most wealthy of the country, but in independent and comfortable circumstances." Their position and training were those of the well-educated and liberal country squire. James's education was begun at an excellent school kept by a Scotchman named Donald Robertson, and his studies preparatory for college were completed at home under the care of the clergyman of the parish. 
His father was colonel of the county militia, like Jefferson's father in the next county, and James could always remember the misery which followed upon Braddock's defeat, though he was only four years old at the time. His intimacy with Thomas Jefferson began at an early age, and led to a beautiful friendship which lasted through life. There was probably no other man for whom Jefferson felt such profound respect as for Madison, and the feeling was fully reciprocated. There were many points of resemblance between the two, such as the sweetness and purity of nature, the benevolence, the liberality of mind, the tireless industry, the intense thirst for knowledge; but nothing could have been more striking than the contrast in outward appearance between the colossal, athletic Jefferson, rosy and fresh as a boy until late in life, and the prim, little, weazen Madison, looking old before he was grown up. The excessive mental labour which the stronger man, aided by his horse and gun, could endure with impunity, made the other ill. When in college and afterward, Madison had to struggle against poor health. He was graduated at Princeton in 1772 , and remained there another year, devoting himself to the study of Hebrew. On returning home he occupied himself with history, law, and theology, while teaching his brothers and sisters. Of the details of his youthful studies little is known, but his industry must have been very great; for in spite of the early age at which he became absorbed in the duties of public life, the range and solidity of his acquirements were extraordinary. For minute and thorough knowledge of ancient and modern history and of constitutional law, he was quite unequalled among the 
Americans of the Revolutionary period; only Hamilton, Ellsworth, and Marshall approached him even at a distance. The early maturity of his power was not so astonishing as in Hamilton's case, but it was remarkable, and, like Washington, he was distinguished in youth for soundness of judgment and keenness of perception. Along with these admirable qualities, his lofty integrity and his warm interest in public affairs were well known to the people of Orange County, so that when, in the autumn of 1774 , it was thought necessary to appoint a committee of safety, Madison was its youngest member. Early in 1776 he was chosen a delegate to the state convention, which met at Williamsburg in May. The first business of the convention was to instruct the Virginia delegation in the Continental Congress with regard to an immediate declaration of independence. Next came the work of making a constitution for the state, and Madison was one of the special committee appointed to deal with this problem. Here one of his first acts was highly characteristic. Religious liberty was a matter that strongly enlisted his feelings. When it was proposed that, under the new constitution, "all men should enjoy the fullest toleration in the exercise of religion, according to the dictates of conscience," Madison pointed out that this provision did not go to the root of the matter. The free exercise of religion, according to the dictates of conscience, is something which every man may demand as a right, not something for which he must ask as a privilege. To grant to the state the power of tolerating is implicitly to grant to it the power of prohibiting, whereas Madison would deny to it any jurisdiction whatever in the matter of religion. 
The clause in the bill of rights, as finally adopted at his suggestion, accordingly declares that "all men are equally entitled to the free exercise of religion, according to the dictates of conscience." The incident illustrates not only Madison's liberality of spirit, but also his precision and forethought in so drawing up an instrument as to make it mean all that it was intended to mean. In his later career these qualities were especially brilliant and useful.

Madison was elected a member of the first legislature under the new state constitution, but he failed of reëlection because he refused to solicit votes or to furnish whiskey for thirsty voters. The new legislature then elected him a member of the governor's council, and in 1780 he was sent as delegate to the Continental Congress. The high consideration in which he was held showed itself in the number of important committees to which he was appointed. As chairman of a committee for drawing up instructions for John Jay, then minister at the court of Madrid, he insisted that in making a treaty with Spain our right to the free navigation of the Mississippi River should on no account be surrendered. Mr. Jay was instructed accordingly, but toward the end of 1780 the pressure of the war upon the Southern states increased the desire for an alliance with Spain to such a point that they seemed ready to purchase it at any price. Virginia therefore proposed that the surrender of our rights upon the Mississippi should be offered to Spain as the condition of an offensive and defensive alliance. Such a proposal was no doubt ill advised. Since Spain was already, on her own account and to the best of her ability, waging 
war upon Great Britain in the West Indies and Florida, to say nothing of Gibraltar, it is doubtful if she could have done much more for the United States, even if we had offered her the whole Mississippi Valley. The offer of a permanent and invaluable right in exchange for a temporary and questionable advantage seemed to Mr. Madison very unwise; but as it was then generally held that in such matters representatives must be bound by the wishes of their constituents, he yielded, though under protest. But hardly had the fresh instructions been despatched to Mr. Jay when the overthrow of Cornwallis again turned the scale, and Spain was informed that, as concerned the Mississippi question, Congress was immovable. The foresight and sound judgment shown by Mr. Madison in this discussion added much to his reputation.

His next prominent action related to the impost law proposed in 1783 . This was, in some respects, the most important question of the day. The chief source of the weakness of the United States during the Revolutionary War had been the impossibility of raising money by means of federal taxation. As long as money could be raised only through requisitions upon the state governments, and the different states could not be brought to agree upon any method of enforcing the requisitions, the state governments were sure to prove delinquent. Finding it impossible to obtain money for carrying on the war, Congress had resorted to the issue of large quantities of inconvertible paper, with the natural results. There had been a rapid inflation of values, followed by sudden bankruptcy and the prostration of national credit. In 1783 it had become difficult to obtain foreign loans, 
and at home the government could not raise nearly enough money to defray its current expenses. To remedy the evil, a tariff of five per cent upon sundry imports, with a specific duty upon others, was proposed in Congress and offered to the several states for approval. To weaken as much as possible the objections to such a law, its operation was limited to twenty-five years. Even in this mild form, however, it was impossible to persuade the several states to submit to federal taxation. Virginia at first assented to the impost law, but afterward revoked her action. On this occasion Mr. Madison, feeling that the very existence of the nation was at stake, refused to be controlled by the action of his constituents. He persisted in urging the necessity of such an impost law, and eventually had the satisfaction of seeing Virginia adopt his view of the matter.

The discussion of the impost law in Congress revealed the antagonism between the slave states and those states which had emancipated their slaves. In endeavouring to apportion the quotas of revenue to be required of the several states, it was observed that, if taxation were to be distributed according to population, it made a great difference whether slaves were to be counted as population or not. If slaves were to be counted, the Southern states would have to pay more than their equitable share into the federal treasury; if slaves were not to be counted, it was argued at the North that they would be paying less than their equitable share. Consequently at that time the North was inclined to maintain that the slaves were population, while the South preferred to regard them as chattels. The question was settled 
by a compromise proposed by Mr. Madison: the slaves were rated as population, but in such wise that five of them were counted as three persons.

In 1784 Mr. Madison was again elected to the Virginia legislature, an office then scarcely inferior in dignity, and superior in influence, to that of delegate to the Continental Congress. His efforts were steadfastly devoted to the preparation and advancing of measures calculated to increase the strength of the federal government. He supported the proposed amendment to the Articles of Confederation, giving to Congress control over the foreign trade of the states; and pending the adoption of such a measure he secured the passage of a port bill restricting the entry of foreign ships to certain specified ports. The purpose of this was to facilitate the collection of revenue, but it was partially defeated in its operation by successive amendments increasing the number of ports. While the weakness of the general government and the need for strengthening it were daily growing more apparent, the question of religious liberty was the subject of earnest discussion in the Virginia legislature. An attempt was made to lay a tax upon all the people "for the support of teachers of the Christian religion." At first Madison was almost the only one to see clearly the serious danger lurking in such a tax; that it would be likely to erect a State Church and curtail men's freedom of belief and worship. Madison's position here well illustrated the remark that intelligent persistence is capable of making one person a majority. His energetic opposition resulted at first in postponing the measure. Then he wrote a "Memorial and Remonstrance," setting forth its dangerous charac- 
ter with wonderful clearness and cogency. He sent this paper all over the state for signatures, and in the course of a twelvemonth had so educated the people that in the election of 1785 the question of religious freedom was made a test question; and in the ensuing session the dangerous bill was defeated, and in place thereof it was enacted "that no man shall be compelled to frequent or support any religious worship, place, or ministry whatsoever, nor shall be enforced, restrained, molested, or burthened in his body or goods, nor shall otherwise suffer on account of his religious opinions or belief; but that all men shall be free to profess, and by argument maintain, their opinions in matters of religion, and that the same shall in no wise diminish, enlarge, or affect their civil capacities." In thus abolishing religious tests, Virginia came to the front among all the American states, as Massachusetts had come to the front in the abolition of negro slavery. Nearly all the states still imposed religious tests upon civil office holders, from simply declaring a general belief in the infallibleness of the Bible, to accepting the doctrine of the Trinity. Madison's "Religious Freedom Act" was translated into French and Italian, and was widely read and commented upon in Europe. In our own history it set a most valuable precedent for other states to follow.

The attitude of Mr. Madison with regard to paper money was also very important. The several states had then the power of issuing promissory notes and making them a legal tender, and many of them shamefully abused this power. The year I 786 witnessed perhaps the most virulent craze for paper money that has ever attacked the American people. In Virginia 
the masterly reasoning and the resolute attitude of a few great political leaders saved the state from yielding to the delusion, and among these leaders Madison was foremost. But his most important work in the Virginia legislature was that which led directly to the Annapolis convention, and thus ultimately to the framing of the Constitution of the United States. The source from which such vast results were to flow was the necessity of an agreement between Maryland and Virginia with regard to the navigation of the Potomac River and the collection of duties at ports on its banks. Commissioners, appointed by the two states to discuss this question, met early in 1785 , and recommended that a uniform tariff should be adopted and enforced upon both banks. But a further question, also closely connected with the navigation of the Potomac, now came up for discussion. The tide of westward migration had for some time been pouring over the Alleghanies, and, owing to complications with the Spanish power in the Mississippi Valley, there was some danger that the United States might not be able to keep its hold upon the new settlements. It was necessary to strengthen the commercial ties between East and West, and to this end the Potomac Company was formed for the purpose of improving the navigation of the upper waters of the Potomac and connecting them by good roads and canals with the upper waters of the Ohio at Pittsburg - an enterprise which in due course of time resulted in the Chesapeake and Ohio Canal. The first president of the Potomac Company was George Washington, who well understood that the undertaking was quite as important in its political as in its commercial bearings. At the 
same time it was proposed to connect the Potomac and Delaware rivers with a canal, and a company was organized for this purpose. This made it desirable that the four states - Virginia, Maryland, Delaware, and Pennsylvania - should agree upon the laws for regulating interstate traffic through this system of waterways. But from this it was but a short step to the conclusion that, since the whole commercial system of the United States confessedly needed overhauling, it might perhaps be as well for all the thirteen states to hold a convention for considering the matter. When such a suggestion was communicated from the legislature of Maryland to that of Virginia, it afforded Madison the opportunity for which he had been eagerly waiting. Some time before he had prepared a resolution for the appointment of commissioners to confer with commissioners from the other states concerning the trade of the country and the advisableness of intrusting its regulation to the federal government. This resolution Madison left to be offered to the assembly by some one less conspicuously identified with Federalist opinions than himself; and it was accordingly presented by John Tyler, father of the future President of that name. The motion was unfavourably received and was laid upon the table; but when the message came from Maryland the matter was reconsidered and the resolution passed. Annapolis was selected as the place for the convention, which assembled September I I, I 786. Only five states - Virginia, Delaware, Pennsylvania, New Jersey, and New York - were represented at the meeting. Maryland, which had first suggested the convention, had seen the appointed time arrive without even taking 
the trouble to select commissioners. As the representation was so inadequate, the convention thought it best to defer action, and accordingly adjourned after adopting an address to the states, which was prepared by Alexander Hamilton. The address incorporated a suggestion from New Jersey, which indefinitely enlarged the business to be treated by such a convention; it was to deal not only with the regulation of commerce, but with "other important matters." Acting upon this cautious hint, the address recommended the calling of a second convention, to be held at Philadelphia on the second Monday of May, I787. Mr. Madison was one of the commissioners at Annapolis, and was very soon appointed a delegate to the new convention, along with Washington, Randolph, Mason, and others. The avowed purpose of the new convention was to "devise such provisions as shall appear necessary to render the Constitution of the federal government adequate to the exigencies of the Union, and to report to Congress such an act as, when agreed to by them, and confirmed by the legislatures of every state, would effectually provide for the same." The report of the Annapolis commissioners was brought before Congress in October, in the hope that Congress would earnestly recommend to the several states the course of action therein suggested. At first the objections to the plan prevailed in Congress, but the events of the winter went far toward persuading men in all parts of the country that the only hope of escaping anarchy lay in a thorough revision of the imperfect scheme of government under which we were then living. The paper money craze in so many of the states, the violent proceedings in the Rhode Island 
legislature, the riots in Vermont and New Hampshire, the Shays rebellion in Massachusetts, the dispute with Spain about the navigation of the Mississippi, and the consequent imminent danger of separation between North and South, had all come together; and now the last ounce was laid upon the camel's back in the failure of the impost amendment. In February, I 787 , just as Mr. Madison, who had been chosen a delegate to Congress, arrived in New York, the legislature of that state refused its assent to the amendment, which was thus defeated. Thus, only three months before the time designated for the meeting of the Philadelphia convention, Congress was decisively informed that it would not be allowed to take any effectual measures for raising a revenue. This accumulation of difficulties made Congress much more ready to listen to the weighty arguments of Mr. Madison, and presently Congress itself proposed a convention at Philadelphia identical with the one recommended by the Annapolis commissioners, and thus in its own way sanctioned their action.

The assembling of the convention at Philadelphia was an event to which Madison, by persistent energy and skill, had contributed more than any other man in the country, with the possible exception of Hamilton. It was in the convention that Madison did the greatest work of his life. Before the convention met he had laid before his colleagues of the Virginia delegation the outlines of the scheme that was presented to the convention as the "Virginia plan." Of the delegates Edmund Randolph was then governor of Virginia, and it was he that presented the plan and made the opening speech in defence of it; but its chief author 
was Madison. This "Virginia plan" struck directly at the root of the evils from which our federal government had suffered under the articles of confederation. The weakness of that government had consisted in the fact that it operated only upon states, and not upon individuals. Only states, not individuals, were represented in the Continental Congress, which accordingly resembled a European congress rather than an English parliament. According to the ideas entertained at the time of the Revolution, the legislative assembly of each state was its House of Commons; in one state, North Carolina, it was called by that name. Congresses were extraordinary meetings of delegates held on occasions when the several states felt it necessary to consult with each other, just as sometimes happens in Europe. There was a Congress at Albany in I 754, and one at New York in 1765 , and one at Philadelphia in 1774 ; the advent of war and revolution had made this last one permanent, and it was the only body that represented the United States as a whole. Yet the delegates were much more like envoys from sovereign states than like members of a legislative body. They might deliberate and advise, but had no means of enforcing their will upon the several state governments; and hence they could neither raise a revenue nor preserve order. Now the cure for this difficulty, devised by Madison and first suggested in the "Virginia plan," lay in transforming the Congress into a parliament, in making it a national legislature elected by the whole American people and having the same authority over them that each state legislature was wont to exercise over the people of its own state. It was really throwing Congress overboard and creating a parliament 
instead, only it would not do to call it so, because Americans at that time were not fond of the name. The new House of Representatives could of course tax the people because it represented them. For the same reason it could make laws, and to enable it to enforce them there was to be a federal executive and a federal judiciary. To the familiar state governments under which people lived Madison thus superadded another government, complete in all its branches and likewise coming into direct contact with the people. And yet this new government was not to override the old ones; state governors are not subordinate to the President, or state legislatures to Congress; each is sovereign within its own sphere. This was the supreme act of creative statesmanship that made our country what it is; transforming it, as the Germans say, from a Staatesnbund into a Bundesstaat, or, as I may translate these terms, from a Band-of-States into a BandedState. All this seems natural enough now, but the men who could thus think out the problem a century ago must be ranked as high among constructive statesmen as Newton among scientific discoverers. It is to Madison that we owe this grand and luminous conception of the two coexisting and harmonious spheres of government, although the Constitution, as actually framed, was the result of skilful compromises by which the Virginia plan was modified and improved in many important points. In its original shape that plan went farther toward national consolidation than the Constitution as adopted. It contemplated a national legislature to be composed of two houses, but both the upper and the lower house were to represent population instead of states. Here it encountered fierce opposition 
from the smaller states, under the lead of New Jersey, until the matter was settled by the famous Connecticut compromise, according to which the upper house was to represent states, while the lower house represented population. Madison's original scheme, moreover, would have allowed the national legislature to set aside at discretion such state laws as it might deem unconstitutional. It may seem strange to find Madison, who afterward drafted the Virginia resolutions of 1798 , now suggesting and defending a provision so destructive of state rights. It shows how strongly he was influenced at the time by the desire to put an end to the prevailing anarchy. The discussion of this matter in the convention, as we read it to-day, brings out in a very strong light the excellence of the arrangement finally adopted, by which the constitutionality of state laws is left to be determined through the decision of the federal Supreme Court.

In all the discussions in the federal convention, Madison naturally took a leading part. Besides the work of cardinal importance which he achieved as principal author of the Virginia plan, especial mention must be made of the famous compromise that adjusted the distribution of representatives between the Northern and the Southern states. We have seen that in the Congress of I $_{7} 8_{3}$, when it was a question of taxation, the South was inclined to regard slaves as chattels, while the North preferred to regard them as population. Now, when it had come to be a question of the apportionment of representation, the case was reversed; it was the South that wished to count slaves as population, while the North insisted that they should be classed as chattels. Here Mr. Madison 
proposed the same compromise that had succeeded in Congress four years before; and Mr. Rutledge, of South Carolina, who had supported him on the former occasion, could hardly do otherwise than come again to his side. It was agreed that in counting population, whether for direct taxation or for representation in the lower house of Congress, five slaves should be reckoned as three individuals. In the history of the formation of our federal Union, this compromise was of cardinal importance. Without it the Union would undoubt. edly have gone to pieces at the outset, and it was for this reason that the northern Abolitionists, Gouverneur Morris and Rufus King, joined with Washington and Madison, and with the pro-slavery Pinckneys, in subscribing to it. Some of the evils resulting from this compromise have led historians, writing from the Abolitionist point of view, to condemn it utterly. Nothing can be clearer, however, than that, in order to secure the adoption of the Constitution, it was absolutely necessary to satisfy South Carolina. This was proved by the course of events in I 788 , when there was a strong party in Virginia in favour of a separate confederacy of Southern states. By South Carolina's prompt ratification of the Constitution, this scheme was completely defeated, and a most formidable obstacle to the formation of a more perfect union was removed. Of all the compromises in American history, this of the so-called "three-fifths rule" was probably the most important; until the beginning of the Civil War, there was hardly a political movement of any consequence that was not affected by it.

Mr. Madison's services in connection with the founding of our federal government were thus, up to 
this point, of the most transcendent kind. We have seen that he played a leading part in the difficult work of getting a convention to assemble; the merit of this he shares with other eminent men, and notably with Washington and Hamilton. Then he was chief author of the most fundamental features in the Constitution, those which transformed our government from a loose and feeble confederacy of states into a strong federal nation; and to him is due the principal credit for the compromise that made the adoption of the Constitution possible for all the states. After the adjournment of the convention his services did not cease. Among those whose influence in bringing about the ratification of the Constitution was felt all over the country, he shares with Hamilton the foremost place. According to his own memorandum he was the author of twenty-nine of the essays in the "Federalist," while fifty-one were written by Hamilton and five by Jay. Some of the essays, however, seem to have been written by Madison and Hamilton jointly, and as to others there has been more or less dispute. The question is not of great importance. Very likely Madison would have had a larger share in the work had he not been obliged, in March, I 788, to return to Virginia, in order to take part in the state convention for deciding upon the ratification of the Constitution. Here the task before him, though not so arduous as that of Hamilton in the New York convention, was arduous enough. Unlike his friend Jefferson, who could hardly speak in public, Madison was one of the most formidable parliamentary debaters that ever lived. Without a particle of eloquence or of what is called personal magnetism, with a dry style and a mild, unimpassioned 
delivery, he would nevertheless have been a fair match for Charles Fox or the younger Pitt. His vast knowledge was always at command, his ideas were always clear and his grasp of the situation perfect, and although he was so modest that the colour came and went upon his cheeks as upon a young girl's, he was never. flurried or thrown off his guard. He represented pure intelligence, which is doubtless one reason why his popular fame has not been equal to his merit. There is nothing especially picturesque about pure intelligence, but it is a great power nevertheless. The opposition in Virginia was strong and well organized, and had for leaders such eminent patriots as Patrick Henry and Richard Henry Lee. The alliance between South Carolina and the New England states, which in exchange for a prolongation of the foreign slave-trade for twenty years gave to Congress the power of regulating commerce by a simple majority vote, had alarmed Virginia. It was feared that it would enable the Northern states to enter upon a commercial policy in which the interests of Virginia would be disregarded. There was also a party from the Kentucky district, which was disgusted at the Northern indifference to the free navigation of the Mississippi River, and thought that the interests of all that part of the country could best be secured by a separate Southern confederacy. As just observed, South Carolina had already defeated this dangerous scheme by ratifying the Constitution. Nevertheless, when the Virginia convention met, the opponents of the Constitution were doubtless in the majority. The debates lasted nearly a month, and for a considerable part of this time the outlook was not promising. The discussion 
was conducted mainly between Madison and Henry, the former being chiefly assisted by Randolph, Wythe, Marshall, Pendleton, and young Henry Lee; the latter by Mason, Monroe, Harrison, and Tyler. To Madison, more than to any one else, it was due that the Constitution was at length ratified, while the narrowness of the majority - eighty-nine to seventy-nine bore witness to the severity of the contest. It did not appear that the people of Virginia were even yet convinced by the arguments that had prevailed in the convention. The assembly that met in the following October showed a heavy majority of Anti-federalists, and under Henry's leadership it called upon Congress for a second national convention, to reconsider the work done by the first. Senators were now to be chosen for the first United States Senate, and Henry, in naming Richard Henry Lee and William Grayson, both Anti-federalists, as the two men who ought to be chosen, took pains to mention James Madison as the one man who on no account whatever ought to be elected senator. Henry was successful in carrying this point. The next thing was to keep Madison out of Congress, and Henry's friends sought to accomplish this by means of the device afterward known as "gerrymandering"; but the attempt failed, and Madison was elected to the first national House of Representatives. His great knowledge, and the part he had played in building up the framework of the government, made him from the outset the leading member of the House. His first motion was one for raising a revenue by tariff and tonnage duties. He offered the resolutions for creating the executive departments of foreign affairs, of the treasury, and of war. $\mathrm{He}$ 
proposed twelve amendments to the Constitution, in order to meet the objection, urged in many quarters, that that instrument did not contain a bill of rights. The first ten of these amendments were adopted, and became part of the Constitution in I79I.

The first division of political parties under the Constitution began to show itself in the debates upon Hamilton's financial measures as Secretary of the Treasury, and in this division we see Madison acting as leader of the opposition. By many writers this has been regarded as indicating a radical change of attitude on his part, and sundry explanations have been offered to account for the presumed inconsistency. He has been supposed to have succumbed to the personal influence of Jefferson, and to have yielded his own convictions to the desires and prejudices of his constituents. Such explanations are hardly borne out by what we know of Madison's career up to this point; and, moreover, they are uncalled for. If we consider carefully the circumstances of the time, the presumed inconsistency in his conduct disappears. The new Republican party, of which he soon became one of the leaders, was something quite different in its attitude from the Anti-federalist party of 1787-1790. There was ample room in it for men who, in those critical years, had been stanch Federalists, and as time passed this came to be more and more the case, until, after a quarter of a century, the entire Federalist party, with the exception of a few inflexible men in New England, had been absorbed by the Republican party. In I 790, since the federal Constitution had been actually adopted and was going into operation, and since the extent of power that it granted to the general govern- 
ment must be gradually tested by the discussion of specific measures, it followed that the only natural and healthful division of parties must be the division between strict and loose constructionists. It was to be expected that Anti-federalists would become strict constructionists, and so most of them did, though examples were not wanting of such men swinging to the opposite extreme of politics and advocating an extension of the powers of the federal government. This was the case with Patrick Henry. But there was no reason in the world why a Federalist of $1787-1790$ must thereafter, in order to preserve his consistency, become a loose constructionist. It was entirely consistent for a statesman to advocate the adoption of the Constitution, while convinced that the powers specifically granted therein to the general government were ample and that great care should be taken not to add indefinitely to such powers through rash and loose methods of interpretation. Not only is such an attitude perfectly reasonable in itself, but it is, in particular, the one that a principal author of the Constitution would have been very likely to take; and no doubt it was just this attitude that Mr. Madison took in the early sessions of Congress. The occasions on which he assumed it were, moreover, eminently proper, and afford an admirable illustration of the difference in temper and mental habit between himself and Hamilton. The latter had always more faith in the heroic treatment of political questions than Madison. The restoration of American credit in 1790 was a task that demanded heroic measures, and it was fortunate that we had such a man as Hamilton to undertake it. But undoubtedly the assumption of state debts by the 
federal government, however admirably it met the emergency of the moment, was such a measure as might easily create a dangerous precedent, and there was certainly nothing strange or inconsistent in Madison's opposition to it. A similar explanation will cover his opposition to Hamilton's national bank; and indeed, with the considerations here given as a clew, there is little or nothing in Mr. Madison's career in Congress that is not thoroughly intelligible. At the time, however, the Federalists, disappointed at losing a man of so much power, misunderstood his acts and misrepresented his motives, and the old friendship between him and Hamilton gave way to mutual distrust and dislike. In the political agitation caused by the French Revolution, Mr. Madison sympathized with the revolutionists, though he did not go so far in this direction as Jefferson. In the debates upon Jay's treaty with Great Britain, he led the opposition, and earnestly supported the resolution asking President Washington to submit to the House of Representatives copies of the papers relating to the negotiation. After three weeks of debate the resolution was passed, but Washington refused the request on the ground that the making of treaties was intrusted by the Constitution to the President and the Senate, and that the lower house was not entitled to meddle with their work.

At the close of Washington's second administration, Mr. Madison retired for a brief season from public life. During this difficult period the country had been fortunate in having, as leader of the opposition in Congress, a man so wise in counsel, so temperate in spirit, and so courteous in demeanour. Whatever else 
might be said of Madison's conduct in opposition, it could never be called factious; it was calm, generous, and disinterested. About two years before the close of his career in Congress, he married Mrs. Dolly Payne Todd, a beautiful widow, much younger than himself; and about this time he seems to have built the house at Montpelier which was to be his home during his later years. But retirement from public life, in any real sense of the phrase, was not yet possible for such a man. The wrath of the French government over Jay's treaty led to depredations upon American shipping, to the sending of commissions to Paris, and to the blackmailing attempts of Talleyrand, as shown up in the X. Y. Z. despatches. In the fierce outburst of indignation that in America greeted these disclosures, in the sudden desire for war with France, which went so far as to vent itself in actual fighting on the sea, though war was never declared, the Federalist party believed itself to be so strong that it proceeded at once to make one of the greatest blunders ever made by a political party, in passing the alien and sedition acts. This high-handed legislation caused a sudden revulsion of feeling in favour of the Republicans, and called forth vigorous remonstrance. Party feeling has perhaps never in this country been so bitter, except just before the Civil War. A series of resolutions, drawn up by Madison, was adopted in 1798 by the legislature of Virginia; while a similar series, still more pronounced, drawn up by Jefferson, was adopted in the same year by the legislature of Kentucky. The Virginia resolutions asserted with truth that, in adopting the federal Constitution, the states had surrendered only a limited portion of their powers; and went on to 
declare that, whenever the federal government should exceed its constitutional authority, it was the business of the state governments to interfere and pronounce such action unconstitutional. Accordingly, Virginia declared the alien and sedition laws unconstitutional, and invited the other states to join in the declaration. Not meeting with a favourable response, Virginia renewed these resolutions the next year. There was nothing necessarily seditious, or tending toward secession, in the Virginia resolutions; but the attitude assumed in them was uncalled for on the part of any state, inasmuch as there existed, in the federal Supreme Court, a tribunal competent to decide upon the constitutionality of acts of Congress. The Kentucky resolutions went farther. They declared that our federal Constitution was a compact, to which the several states were the one party and the federal government was the other, and each party must decide for itself as to when the compact was infringed, and as to the proper remedy to be adopted. When the resolutions were repeated, in I799, a clause was added, which went still further and mentioned "nullification" as the suitable remedy, and one that any state might employ. In the Virginia resolutions there was neither mention nor intention of nullification as a remedy. Mr. Madison lived to witness South Carolina's attempt at nullification in 1832 , and in a very able paper, written in the last year of his life, he conclusively refuted the idea that his resolutions of 1798 afforded any justification for such an attempt, and showed that what they really contemplated was a protest on the part of all the state governments in common. Doubtless such a remedy was clumsy and impracticable, and the sugges- 
tion of it does not deserve to be ranked along with Mr. Madison's best work in constructive statesmanship; but it certainly contained no logical basis for what its author unsparingly denounced as the "twin heresies" of nullification and secession.

With regard to the Kentucky resolutions the case is different. They certainly furnished a method of stating the case, as to the relations between the states and the federal government, of which Calhoun afterward made use in developing his theory of nullification. There has been much interesting discussion as to how far Jefferson is to be held responsible for this view. But this discussion has generally proceeded upon the tacit and perhaps unconscious assumption that in I 798 such an idea as that of nullification was a novel heresy, and that in lending countenance to it, even in the slightest degree, Jefferson figured as in some sense the inventor of a notion which bore fruit in the secession movement of 186 I and the great Civil War. A dispassionate student of history can have no wish to absolve Jefferson or any one else from the proper responsibility for his political acts. But the way in which this case is usually stated, and still more the mood in which it is apt to be stated, is not strictly historical. It would be more instructive to bear in mind that, in 1798 , before Marshall's career as chief justice had begun, the functions of the Supreme Court and its efficiency in checking usurpations of power were as yet mere matter of theory and very imperfectly realized by the people; that the new government was as yet an experiment believed by half the people to be a very hazardous experiment; that thus far its 
administration had been monopolized by one party, the measures of which, even when most beneficial, had been regarded with widespread distrust and dread; and that this distrust now seemed all at once to be justified by the passage of laws that were certainly the most atrocious in all our history except the Fugitive Slave Law. If under these circumstances there were some who believed that a confederacy in which such laws might be nullified was preferable to a Union in which men might be sent to jail, as under the Stuart kings, for expressing their honest opinions in the newspapers, we ought not to blame them. Such a Union would not have been worth the efforts that it cost to frame it. Taught by experience, we can now see that the fears expressed or implied in the Kentucky resolutions were really groundless. But that they were so, that the people were relieved of such fears and the public confidence restored, so that the Union began for the first time to be really loved and cherished - with a sentiment of loyalty, was due chiefly to Jefferson's election as President in 1800 and the conservative policy which he thereafter pursued. When the government passed out of the hands of the party which had enacted the alien and sedition laws, the dread subsided, and the vitality of the Kentucky resolutions was suspended until Calhoun revived it thirty years later. When that new crisis came, the exigency was such that, if Calhoun had not found the letter of these resolutions ready to hand, the sentiment nevertheless existed, out of which he would have made his doctrines.

In I 799 Madison was again elected a member of the Virginia legislature, and in I80I, at Jefferson's 
urgent desire, he became Secretary of State. In accepting this appointment, he entered upon a new career, in many respects different from that which he had hitherto followed. His work as a constructive statesmanwhich was so great as to place him in the foremost rank among the men that have built up nations - was by this time substantially completed. During the next few years the constitutional questions that had hitherto occupied him played a part subordinate to that played by questions of foreign policy, and in this new sphere Mr. Madison was not, by nature or training, fitted to exercise such a controlling influence as he had formerly brought to bear in the framing of our federal government. As Secretary of State, he was an able lieutenant to Mr. Jefferson, but his genius was not that of an executive officer so much as that of a lawgiver. He brought his great historical and legal learning to bear in a paper entitled "An Examination of the British Doctrine which subjects to Capture a Neutral Trade not Open in the Time of Peace." But the troubled period that followed the rupture of the treaty of Amiens was not one in which legal arguments, however masterly, counted for much in bringing angry and insolent combatants to terms. In the gigantic struggle between England and Napoleon, the commerce of the United States was ground to pieces as between the upper and the nether millstone; and in some respects there is no chapter in American history more painful for an American citizen to read. The outrageous affair of the Leopard and the Chesapeake was but the most flagrant of a series of wrongs and insults, against which Jefferson's embargo was doubtless an absurd and feeble protest, but perhaps at 
the same time pardonable as the only weapon left us in that period of national weakness.

Affairs were drawing slowly toward some kind of crisis when, at the expiration of Jefferson's second term, Mr. Madison was elected President of the United States by 122 electoral votes against 47 for Cotesworth Pinckney and 6 for George Clinton, who received II 3 votes for the vice-presidency, and was elected to that office. The opposition of the New England states to the embargo had by this time brought about its repeal and the substitution for it of the act declaring non-intercourse with England and France. By this time, many of the most intelligent Federalists, including John Quincy Adams, had gone over to the Republicans. In I8 10 Congress repealed the non-intercourse act, which as a measure of intimidation had proved ineffectual. Congress now sought to use the threat of non-intercourse as a kind of bribe, and informed England and France that if either nation would repeal its obnoxious edicts, the non-intercourse act would be revived against the other. Napoleon took prompt advantage of this, and informed $\mathrm{Mr}$. Madison's government that he revoked his Berlin and Milan decrees as far as American ships were concerned; but at the same time he gave secret orders by which the decrees were to be practically enforced as harshly as ever. The lie served its purpose, and Congress revived the non-intercourse act as against Great Britain alone. In I8I I hostilities began on sea and land, in the affair of Tippecanoe and of the President and Little Belt. The growing desire for war was shown in the choice of Henry Clay for Speaker of the House of Representatives, and Mr. 
Madison was nominated for a second term, on condition of adopting the war policy.

The New England Federalists at once accused him here of proving recreant to his own convictions, and the charge has since been often reiterated by Federalist writers. Perhaps it would be more correct to say: that, as to the question of the advisableness of declaring war against England, he did not share in the decided convictions of Clay and Calhoun on the one hand or of the New England leaders on the other. His mind was more evenly balanced, and his natural inclinations led him to shrink from war so long as any other policy was available. As to the entire justice of the war, on our side, there could of course be no doubt. No one called it in question except a few superannuated Federalists in New England. The only question was as to whether a war policy was practicable at that moment, and on this point, in yielding to the arguments of Clay and Calhoun, if Mr. Madison sacrificed convictions, they were certainly not convictions that were deeply rooted. $\mathrm{He}$ did not approach such questions in the mood of an Andrew Jackson, but in the mood of a philosopher, who hesitates and acts sometimes in a yielding to pressure of argument that is akin to weakness. On June 18 , I8I2, war was declared, and before the autumn election a series of remarkable naval victories had made it popular. Mr. Madison was reëlected by I 28 electoral votes, against 89 for De Witt Clinton of New York. The one absorbing event, which filled the greater part of his second term, was the war with Great Britain, which was marked by some brilliant victories and some grave disasters, including the cap- 
ture of Washington by British troops and the flight of the government from the national capital. Whatever opinion may be held as to the character of the war and its results, there is a general agreement that its management, on the part of the United States, was feeble. Mr. Madison was essentially a man of peace, and as the manager of a great war he was conspicuously out of his element. The history of that war plays a great part in the biographies of the military and naval heroes that figured in it; it is a cardinal event in the career of Andrew Jackson or Isaac Hull. In the biography of Madison it is an episode, which may be passed over briefly. The greatest part of his career was finished before he held the highest offices; his immortal renown will rest chiefly or entirely upon what he did before the beginning of the nineteenth century.

After the close of his second term, in $1817, \mathrm{Mr}$. Madison retired to his estate at Montpelier, where he spent nearly twenty happy years with books and friends. This sweet and tranquil old age he had well earned by services to his fellow-creatures such as it is given to but few men to render. Among intelligent students of history, there is no one now who would dispute his claim to be ranked beside Washington, Hamilton, Jefferson, and Marshall in the founding of our nation. But his part was peculiar. Of all these great men, he was preëminently the modest scholar and the profound thinker. There was just one moment at which he was the greatest of all, and that was the moment when his grand path-breaking itea was presented to the federal convention in the shape of the Virginia plan. The idea of the twofold government, so 
simple now, so abstruse then, was Madison's idea. And it was the central idea, the fruitful idea, something which every one else would have missed, that we owe to this quiet, unassuming, unpicturesque little man, - this acute thinker and rare constructive genius, James Madison. 
VI

ANDREW JACKSON

FRONTIERSMAN AND SOLDIER 



\section{VI}

\section{ANDREW JACKSON}

\section{FRONTIERSMAN AND SOLDIER}

In one of the debates on the Oregon question in the United States Senate, about five and fifty years ago, Senator McDuffie of South Carolina laughed to scorn the idea that such a remote country as Oregon could ever be of the slightest use to us. Just imagine a state, said he, the representatives from which would require the whole of the year to get to Washington and back! It was because of this short-sightedness, which was shared by all our Eastern statesmen, that we consented to divide the disputed territory with Great Britain. If our government could only then have followed the wise and bold advice of the far-sighted Benton, the whole of that magnificent country now known as British Columbia might have been ours, and in all probability without a war.

But if those statesmen who thought the northern Pacific coast not worth fighting for seem narrowminded, what shall be said of the views expressed by Gouverneur Morris in the convention that framed the Constitution of the United States? Morris was not only one of the most brilliant men in that wonderful convention, but as far as the original thirteen states were concerned he was inclined to broad and liberal views. But when it came to the imperial domain com- 
prised between the Alleghany Mountains and the Mississippi River, the country which the superb diplomacy of Adams and Jay had secured for us in the treaty of I 783 , that was for Gouverneur Morris nothing but backwoods. He wanted to have the Constitution so framed that this region should forever be kept subordinate to the Atlantic States. It would never do, he said, to intrust too much legislative power to illiterate backcountry people; it needed the wisdom that is found in citiess and in polite society to hold them in check and prevent them from filling the statute book with absurd and dangerous laws. It was gravely to be feared that the population of the Mississippi Valley might by and by come to exceed that of the Atlantic coast; and accordingly this descendant of New York patroons desired that some provision should be made by which in such an event the minority might rule. It does not seem to have occurred to him that, when the dreaded day should arrive, this back-country people would occupy a central position and have great cities and polite society of their own, with views as much entitled to consideration as anybody's.

These suggestions of Gouverneur Morris were too impracticable to meet with much favour in the convention, but the feeling which prompted them was common enough at that time and is not yet quite extinct. It is only by slow degrees that the American people have outgrown this old aristocratic notion that political power ought to be confined to certain groups or classes of persons who, for one reason or another, are supposed to be best fitted to exercise it. The Americans of 1787 were not so very unlike their British cousins in their way of looking at such matters, 
and this was especially true of the Federalist leaders, such as Hamilton, John Adams, Pickering, the Pinckneys, and to some extent even Washington. But for the wholesome counter-influence of such men as Jefferson and Gallatin, the political structure reared in I 787 would have rested upon too narrow a basis. For the thorough development of American democracy, however, a second struggle with the wilderness seems to have been needed. The pure American spirit first came to maturity in the breasts of that rugged population that since the days of Daniel Boone and James Robertson had been pouring down the western slope of the Alleghanies and making the beginnings of the two great commonwealths, Kentucky and Tennessee. These were states that from the outset owed no allegiance to a sovereign power beyond the ocean. Their affairs were never administered by British officials, and from the first moment of their existence as organized communities, Great Britain was to them a foreign country. The importance of this new development for a long time passed unnoticed by the older communities on the Atlantic coast, and especially by the New England states, which were the most remote from it alike in geographical position and in social structure. For a long time there was a feeling about the Western country and its inhabitants not unlike that to which Gouverneur Morris gave expression. There was an ignorant superciliousness, such as some Englishmen are still found to entertain toward the United States as a whole. This feeling has been apt to colour the books on American history written by Eastern men. With the best of intentions, and without the least suspicion of the narrowness of their views, such writers, 
while freely admitting the vastness and strength of the Western country, and the picturesqueness of its annals, have utterly failed to comprehend the importance of its share in the political development of the American nation. There could be no better illustration of this than the crudeness of the opinions current in our literature and taught in our text-books concerning the career of Andrew Jackson, the first American citizen who crossed the Alleghanies to take his seat in the White House.

In studying the life of this great man, we must first observe the characteristics of the people among whom his earlier years were spent, and of whom he was to such a marked degree the representative and leader. So much has been said about the great influence of New England in determining the character of the West that we must be careful not to forget that in point of time that influence has been distinctly secondary. It was Virginia, together with the mountain districts of Pennsylvania and the Carolinas, that first determined the character of the West. Before the overflow of population from New England could make much impression upon the Western territory, it had a great work to do in occupying rural New York. While people in Connecticut were still speaking of Syracuse and Rochester as "out West," the pioneers from Virginia and North Carolina had built their log cabins on bluffs overlooking the Mississippi. A little later this powerful Southern swarm passed on into Missouri and Arkansas, and even invaded the Northwestern Territory, where its influence was seen in repeated attempts, on the part of the inhabitants of the regions since known as Indiana and Illinois, to 
persuade Congress to repeal the antislavery clause of the Ordinance of 1787 . In this Southern stream of westward migration three distinct currents were discernible. There were, first, the representatives of old Virginia families moving on parallels of latitude across Kentucky and into Missouri, as fine a race of men as can be found in the world, and always fruitful in able and gallant leaders. In the second place, there were the poor whites, or descendants of the outlaws and indented white servants of the seventeenth century in Virginia; we find them moving across Tennessee into southern Missouri and Arkansas, while some of them made their way into Indiana and the Egyptian district of Illinois. For the most part these men were an unprogressive, thriftless, and turbulent element in society. Thirdly, the men who, perhaps more than any others, gave to the young West its character were the hardy mountaineers of the Alleghany region. If one were required to give a recipe for compounding the most masterful race of men that can be imagined, one could hardly do better than say, "To a very liberal admixture of Scotch and Scotch-Irish with English stock, with a considerable infusion of Huguenot, add a trace of Swiss and Welsh, and set the whole to work for half a century hewing down the forest and waging an exterminating warfare with Indians." From their forefathers in the highlands of Britain these sturdy pioneers inherited an appreciation of the virtues of mountain dew, and the westward march of American civilization has been at all times heralded by the rude temples of that freakish spirit, until the placid German has followed in his turn, with the milder rites of Gambrinus. In religion these men were, for the most 
part, Puritan. There cannot be a greater error than to speak of American Puritanism as peculiar to New England. - That which was peculiar to the New England colonies was not the simple fact of Puritanism, but the manner in which that Puritanism dominated their social structure and determined their political attitude. Their origin dates from the time when the Puritan idea was secking to incarnate itself in a theocratic form of government. That is what has given to New England its distinctive character. As for Puritanism, regarded as an affair of temperament, belief, and mental habit, it has always been widely diffused throughout English-speaking America. There was a rather strong infusion of it in Maryland, and a very strong one in South Carolina; and nowhere do we find the Puritan spirit, with its virtues and its faults, its intensity and its narrowness, more conspicuously manifested than in those children of English dissenters and Scottish covenanters and Huguenot refugees that went forth from the Alleghanies to colonize the Mississippi Valley. Originally their theology was Calvinistic, but during the latter part of the eighteenth century a great wave of Wesleyanism swept over this part of the country, and Baptist preachers also made many converts.

Devout religious sentiment, in this pioneer society, did not succeed in preventing a great deal of turbulence; and herein we find a contrast with early New England, which has in later times left its traces far and wide upon the habits and manners of different parts of the United States. Where the early settler of Connecticut or Massachusetts would seek redress for an injury by appealing to a court of justice, the early 
settler of Tennessee or Kentucky would be very likely to take the law into his own hands. From this have come the vendettas, the street fighting, the lynch law, so conspicuous in the history of the nineteenth century. I am inclined to think that a chief cause of this difference between New England and the Southwest is to be found in a difference in the methods by which the two regions were settled. Rarely, if ever, in New England did individuals or families advance singly into the forest to make new homes for themselves. The migration was always a migration of organized communities. Town budded from town, as in ancient Greece; and the outermost town in the skirts of the wilderness carried with it, not only the strict discipline of church and schoolhouse, but also the whole apparatus of courts and judges, jails and constables, complete and efficient. This was the peculiar feature of the settlement of New England that saved it from the turbulence usually characteristic of frontier communities. When people can obtain justice, with reasonable certainty and promptness, at the hands of the law, they are not likely to be tempted to take the law into their own hands. The turbulence among our Western pioneers was only an ordinary instance of what happens on frontiers where for a time the bonds that hold together the complicated framework of society are somewhat loosened.

This hardy population, which thrust itself into all parts of the West, from the prairies of Illinois to the highlands of northern Alabama, was intensely American and intensely national in its feelings. These people differed from the planters of South Carolina or Louisiana almost as much as from the merchants and 
yeomanry of New England and New York, and when by and by the stress of civil war came, they were the stout ligament that held the Union together. They were, in a certain measure, set free from the excessive attachment to a state government which was so liable to mislead the dweller in the older communities. The governments of the seaboard states were older than the federal Union; but the states west of the Alleghanies were created by the federal Union, and their people felt toward it a strong sense of allegiance. It was sufficient in I86 I to keep Missouri and Kentucky, with portions of Tennessee and Virginia, from joining the Southern Confederacy, which was thus seriously truncated and lamed at the very start.

These considerations will help us to understand the remarkable career of Andrew Jackson. His personal characteristics were in large measure the characteristics of the community in which he lived. There was the intense Americanism, the contempt for things foreign, the love for the Union, the iron tenacity of purpose, the promptness in redressing his own grievances, the earnest Puritan spirit. Some of these characteristics in Jackson, as in his neighbours, came naturally by inheritance. Of all the pugnacious and masterful, single-minded, conscientious, and obstinate Puritans that have ever lived in any country, the first place must doubtless be assigned to those Scotchmen and Yorkshiremen who went over to Ulster and settled there in the reign of James I. Perhaps it was the constant knocking against Irish Catholicism that hammered them out so hard. A good many of them came to America in the course of the eighteenth century, and among these was Andrew Jackson of Car- 
rickfergus, son of Hugh Jackson, linen-draper. Andrew's wife was Elizabeth Hutchinson, and her family were linen-weavers. They came to America in I 765 , the year of the Stamp Act, and before two years had passed Andrew Jackson died, only a few days before the birth of his famous son.

The $\log$ cabin in which the future President was born, on the $15^{\text {th }}$ of March, 1767 , was situated within a quarter of a mile of the boundary between the two Carolinas, and the people of the neighbourhood do not seem to have had a clear idea as to which province it belonged. In a letter of the $24^{\text {th }}$ of December, 1830 , in the proclamation addressed to the nullifiers in 1832 , and again in his will, General Jackson speaks of himself as a native of South Carolina; but the evidence adduced by Parton seems to show that the birthplace may have been north of the border. Three weeks after the birth of her son, Mrs. Jackson moved to the house of her brother-in-law, Mr. Crawford, just over the border in South Carolina, near the Waxhaw Creek, and there Andrew's early years were passed. His education, obtained in an "old-field school," consisted of little more than the "three R's," and even in that limited sphere his attainments were but scanty. His career as a fighter began early. In the spring and summer of 1780 , after the disastrous surrender of Lincoln's army at Charleston, the whole of South Carolina was overrun by the British. On the 6th of August Jackson was present at Hanging Rock, when Sumter surprised and destroyed a British regiment. Two of his brothers, as well as his mother, died from hardships sustained in the war. In after years he could remember how he had been carried as 
prisoner to Camden and nearly starved there, and how a brutal officer had cut him with a sword because he refused to clean his boots; these reminiscences kept alive his hatred for the British, and doubtless gave unction to the tremendous blow that he dealt them at New Orleans. In 178I, left quite alone in the world, he was apprenticed for a while to a saddler. At one time he is said to have done a little teaching in an "old-field school." At the age of eighteen he entered the law office of Spruce McCay in Salisbury. While there he was said to have been "the most roaring, rollicking, game-cocking, horse-racing, card-playing, mischievous fellow" that had ever been seen in that town. Many and plentiful were the wild-oat crops sown at that time; and in such sort of agriculture young Jackson seems to have been more proficient than in the study of jurisprudence. But in that frontier society a small amount of legal knowledge went a good way, and in 1788 he was appointed public prosecutor for the western district of North Carolina, the district since erected into the state of Tennessee. The emigrant wagon train in which Jackson journeyed to Nashville carried news of the ratification of the federal Constitution by the requisite two-thirds of the states. He seems soon to have found business enough. In the April term of 1790 , out of 192 cases on the dockets of the county court at Nashville, Jackson was employed as counsel in 42. In the year I794, out of 397 cases he acted as counsel in 228 , while at the same time he was practising his profession in the courts of other counties. The great number of these cases is an indication of their trivial character. As a general rule they were either actions growing out of 
disputed land claims, or simple cases of assault and battery. Court day was a great occasion in that wild community, bringing crowds of men into the county town to exchange gossip, discuss politics, drink whiskey, and break heads. Probably each court day produced as many new cases as it settled. Amid such a turbulent population the public prosecutor must needs be a man of nerve and resource. Jackson proved himself quite equal to the task of introducing law and order, in so far as it depended on him. "Just inform Mr. Jackson," said Governor Blount, when sundry malfeasances were reported to him; "he will be sure to do his duty, and the offenders will be punished." Besides the lawlessness of the white pioneer population, there was the enmity of the Indians to be reckoned with. In the immediate neighbourhood of Nashville the Indians murdered on the average one person every ten days. From I 788 to I 795 Jackson performed the journey of nearly two hundred miles between Nashville and Jonesboro twenty-two times; and on these occasions there were many alarms from Indians which sometimes grew into quite a forest campaign. In one of these affairs, having nearly lost his life in an adventurous feat, Jackson is said to have made the characteristic remark, "A miss is as good as a mile; you see how near a man can graze danger." It was this wild experience that prepared the way for Jackson's eminence as an Indian fighter. In the autumn of I794 the Cherokees were so thoroughly punished by General Robertson's famous Nickajack expedition that henceforth they thought it best to leave the Tennessee settlements in peace. With the rapid increase of the white population which soon followed, the community 
became more prosperous and more orderly; and in the general prosperity Jackson had an ample share, partly through the diligent practice of his profession, partly through judicious purchase and sales of land.

With most men marriage is the most important event of life; in Jackson's career his marriage was peculiarly important. Rachel Donelson was a native of North Carolina, daughter of Colonel John Donelson, a Virginia surveyor in good circumstances, who in 1780 migrated to the neighbourhood of Nashville in a very remarkable boat journey of two thousand miles, down the Holston and Tennessee rivers, and up the Cumberland. During an expedition to Kentucky some time afterward, the blooming Rachel was wooed and won by Captain Lewis Robards. She was a sprightly girl, the best horsewoman and best dancer in that country; she was, moreover, a person of strong character, excellent heart, and most sincere piety; her husband was a young man of tyrannical and unreasonably jealous disposition. In Kentucky they lived with Mrs. Robards, the husband's mother; and, as was common in a new society where houses were too few and far between, there were other boarders in the family, - among them Judge Overton of Tennessee and a Mr. Stone. Presently Robards made complaints against his wife, in which he implicated Stone. He was even so abusive that his wife became an object of sympathy to the whole neighbourhood, and every one, including Captain Robards's own mother, condemned his behaviour. He had already quarrelled with his wife and sent her home to Nashville before Jackson became acquainted with her. Presently there was a reconciliation, and Robards came to live in Nashville. 
The next object of his jealousy was Jackson. There is superabundant testimony that the conduct of the latter was quite above reproach. One of the most winsome features in Jackson's character was his sincere and chivalrous respect for women. He was also peculiarly susceptible to the feeling of keen sympathy for persons in distress. Robards presently left his wife and went to Kentucky, threatening by and by to return and make her life miserable. His temper was so ugly and his threats so atrocious that Mrs. Robards was frightened, and in order to get quite out of his way, she made up her mind to visit some friends at distant Natchez. In pursuance of this plan, with which the whole neighbourhood seems to have concurred, she went down the river in company with the venerable Colonel Stark and his family. As the Indians were just then on the war-path, Jackson accompanied the party with an armed escort, returning to Nashville as soon as he had seen his friends safely deposited at Natchez. While these things were going on, the proceedings of Captain Robards were characterized by a sort of Machiavellian astuteness. In I 79I Kentucky was still a part of Virginia, and according to the code of the Old Dominion, if a husband wished to obtain a divorce, he must procure an act of the legislature empowering him to bring his case before a jury, and authorizing a divorce conditionally upon the jury's finding the proper verdict. Early in I79I Robards obtained the preliminary act of the legislature upon his declaration that his wife had run away with Jackson. He then deferred further action for more than two years. Meanwhile it was reported and believed in the West that a divorce had been granted; 
probably Robards himself helped spread the report. Acting upon this information, Jackson, whose chivalrous interest in Mrs. Robards's misfortunes had ripened into sincere affection, went in the summer of I79I to Natchez and married her there, and brought her to his home at Nashville. In the autumn of I793 Captain Robards, on the strength of the facts which undeniably existed since the act of the Virginia legislature, brought his case into court and obtained the verdict completing the divorce. On hearing of this, to his intense surprise, in December, Jackson concluded that the best method of preventing future cavil was to procure a new license and have the marriage ceremony performed again ; and this was done in January. Jackson was doubtless to blame for not taking more care to ascertain the import of the act of the Virginia legislature. It was a carelessness peculiarly striking in a lawyer. The irregularity of the marriage was indeed atoned by forty years of honourable and happy wedlock, ending only with Mrs. Jackson's death in December, I828; and no blame was ever attached to the parties in Nashville, where all the circumstances were well known. But the story, half-understood, maliciously warped, and embellished with gratuitous fictions, grew into scandal as it was passed about among Jackson's personal enemies or political opponents; and herein some of the bitterest of his many quarrels had their source. His devotion to Mrs. Jackson was intense, and his loaded pistol was always kept ready for the rash man who should dare to speak of her slightingly.

In January, I796, we find Jackson sitting in the convention assembled at Knoxville for making a con- 
stitution for Tennessee, and tradition has it that he proposed the name of the great crooked river as the name for the new state. Among the rules adopted by the convention, one is quaintly significant: "He that digresseth from the subject to fall on the person of any member shall be suppressed by the Speaker." The admission of Tennessee to the Union was effected in June, 1796 , in spite of vehement opposition from the Federalists, and in the autumn Jackson was chosen as the single representative in Congress. Thus at the age of twenty-nine he received substantial proof of the high esteem in which he was held by his fellowcitizens. When the House had assembled, he heard President Washington deliver in person his last message to Congress. His first act as a representative was characteristic and prophetic; he was one of the twelve extreme Republicans who voted against the adoption of the address to Washington in approval of his administration. Jackson's two great objections to Washington's government were directed against Jay's. treaty with Great Britain and Hamilton's national bank. His feeling toward the Jay treaty was that of a man who could not bear to see anything but blows. dealt to Great Britain, and it was entirely in harmony with the fierce spirit of Americanism growing up behind the Alleghanies, which was by and by to drive the country into war. When one remembers the insolence of the British government in those years, in refusing to fulfil treaty obligations and surrender the northwestern fortresses, in trying to cut off our trade with the West Indies, in impressing our seamen, and in neglecting to send a minister to the United States, one thoroughly sympathizes with Jackson's feeling. 
At the same time it is perfectly clear that Washington was right in insisting upon the ratification of the Jay treaty. It did not give us much satisfaction, but at that moment, and until our new government should have become firmly established, anything was better than war. A good commentary on the soundness of Washington's conduct was to be found in the fact that the British were almost as much disgusted with the treaty as we were. When war was at length declared, in 1812, Lord Sheffield said they would now be revenged upon the Yankees for the concessions extorted by Jay. That it did not turn out so was partly due to the valour of the young man who now sat chafing at Washington's moderation. Jackson's other objection shows that even at that early day he felt that banking is not a part of the legitimate business of government. The year I 797 was a season of financial depression, and the general paralysis of business was ascribed - perhaps too exclusively - to the overissue of notes by the national bank. Jackson's antipathy to that institution was nourished by what he saw and heard at Philadelphia. Of his other votes in this Congress, one was for an appropriation to defray the expenses of Sevier's expedition against the Cherokees, which was carried; three others were eminently wise and characteristic of the man:-

I. For finishing the three frigates then building, and destined to such imperishable renown, the Constitution, Constellation, and United States.

2. Against the further payment of blackmail to Algiers.

3. Against removing "the restriction which con- 
fined the expenditure of public money to the specific objects for which each sum was appropriated."

Three such votes as that, in one Congress, make a noble record. Another vote, foolish in itself, was characteristic of a representative from the backwoods. It was against the presumed extravagance of appropriating $\$ 14,000$ to buy furniture for the newly built White House. Jackson's course throughout was warmly approved by his constituents, and in the following summer he was chosen to fill a vacancy in the federal Senate. Of his conduct as senator little is known beyond the remark made by Jefferson in 1824 to Daniel Webster, that he had often, when presiding in the Senate, seen the passionate Jackson get up to speak and then choke with rage so that he could not utter a word. One need not wonder at this if one remembers what was the subject most frequently brought up for discussion in the Senate during the winter of $1797-1798$. The outrageous insolence of the French Directory was enough to arouse the wrath of a far tamer and less patriotic spirit than Jackson's. It is almost enough to make one choke with rage now, in reading about it after one hundred years. At any rate it is enough to make one rejoice that, although war was never declared, the gallant Truxton did, presently, in two well-fought naval battles, inflict crushing and galling defeat upon the haughty tricolour. Those were the days when the new nation in America was deemed so weak that anybody might insult it with impunity, and France and England vied with each other in bullying and teasing us. Under such treatment it was hard to maintain prudence. Wash- 
ington seriously risked his popularity by averting a quarrel with England in I794; Adams sacrificed his chances for reëlection by refusing to go to war with France in I799. The effect of all this must be borne in mind if we would appreciate the immense and wellearned popularity which Jackson acquired when the time had come to strike back.

In April, I798, Jackson resigned his seat in the Senate, and was appointed judge in the Supreme Court of Tennessee. He retained this position for six years, but nothing is known of his decisions, as the practice of recording decisions began only with his successor, Judge Overton. During this period he was much harassed by business troubles arising from the decline in the value of land consequent upon the financial crisis of 1798 . At length, in 1804 , he resigned his judgeship in order to devote his attention exclusively to his private affairs. He paid up all his debts and engaged extensively both in planting and in trade. He was noted for fair and honourable dealing, his credit was always excellent, and a note with his name on it was considered as good as gold. He had a clear head for business, and was never led astray by the delusions about paper money by which American communities have so often been infested. His plantation was well managed, and his slaves were always kindly and considerately treated.

But while genial and kind in disposition, he was by no means a person with whom it was safe to take liberties. In I 795 he fought a duel with Avery, an opposing counsel, over some hasty words that had passed in the court-room. Next year he quarrelled with John Sevier, the famous governor of Tennessee, 
and came near shooting him "at sight." Sevier had alluded to the circumstances of his marriage. Ten years afterward, for a similar offence, though complicated with other matters in the course of a long quarrel, he fought a duel with Charles Dickinson, a young lawyer of Nashville. The circumstances were such as to show Jackson's wonderful nerve and rare skill in grazing danger. Each man meant to kill the other, and Dickinson was called the most unerring marksman in all that country. It is said that on the way to the place of meeting, as Dickinson and his friends stopped at a tavern for lunch, he amused himself by severing a string with his bullet, and pointing to the hanging remnant, said to the landlord as he rode away, "If Andrew Jackson comes along this road, show him that!" It was in much more serious mood that Jackson, as he made the journey, discussed with Overton, his second, the proper course to pursue. It was decided that, as Dickinson would surely have the advantage in a quick shot, it would be best to let him fire first, and then take deliberate aim at him. When all had arrived upon the ground, at the given signal Dickinson instantly fired. It has been thought that his aim may have been slightly misled by Jackson's extreme slenderness and the loose fit of his coat. Instead of piercing his heart, the ball broke the rib close by and made an ugly wound, which, however, no one observed. It was a moment of sore astonishment for Dickinson when he saw his grim adversary still standing before him. Jackson's trigger had stopped at half cock, but he skilfully raised it into position again, and at his fire Dickinson fell mortally wounded. It was not until they had gone more than 
a hundred yards away from the spot that Jackson opened his coat and disclosed his wound, whereat Overton expressed the greatest surprise that, after such a hurt, he should have been able to remain standing and return his adversary's fire. In Jackson's reply there was a touch of hyperbole. "By the Eternal," said he, "I would have killed him if he had shot me through the brain." The unfortunate Dickinson died that night, cursing his fate and unspeakably chagrined by the belief that he had not hit his enemy. Perhaps it would have consoled him somewhat if he could have known that, after nearly forty years and in a ripe old age, the death of Andrew Jackson was to be caused by the wound received that morning. Such incidents are far from pleasant to tell; indeed, they are revolting in the extreme. But perhaps nothing could better illustrate the unconquerable spirit that carried Jackson through every kind of vicissitude.

About this time Jackson was visited by Aaron Burr, who was then preparing his mysterious Southwestern expedition. Since I80 I Jackson had been commanderin-chief of the Tennessee militia, and Burr seems to have wished, if possible, to make use of his influence in raising troops, but without indicating the purpose for which they were wanted. In this he was unsuccessful. Jackson was not the man to be used as a cat's paw, but he seems to have regarded the charge of treason afterward brought against Burr as ill-founded. At Richmond, while Burr's trial was going on, Jackson made a speech reflecting upon Jefferson, and thus made himself obnoxious to Madison, who was then Secretary of State. Afterward, in I 808, he declared his preference for Monroe over Madison as candidate for 
the presidency. He was considered unfriendly to Madison's administration, but this did not prevent him from offering his services, with those of twenty-five hundred men, as soon as war was declared against Great Britain in 1812 . Late in that year, after the disasters in the Northwest, it was feared that the British might make an attempt upon New Orleans, and Jackson was ordered down to Natchez at the head of two thousand men. He went in high spirits, promising to plant the American eagle upon the ramparts of Mobile, Pensacola, and St. Augustine, if so directed. On the 6th of February, as it had become evident that the British were not meditating a southward expedition, the new Secretary of War Armstrong sent word to Jackson to disband his troops. This stupid order reached the general at Natchez toward the end of March, and inflamed his wrath. He took upon himself the responsibility of marching his men home in a body, an act in which the government afterward acquiesced, and reimbursed Jackson for the expense involved. During this march Jackson became the idol of his troops, and his sturdiness won him the nickname of "Old Hickory," by which he was affectionately known among his friends and followers for the rest of his life.

It was early in September, I8I3, shortly after his return to Nashville, that the affray occurred with Thomas Benton, growing out of an unusually silly duel in which Jackson, with more good nature than discretion, had acted as second to the antagonist of Benton's brother. The case was one which a few calm words of personal explanation might easily have adjusted. But the facts got misrepresented, and both men lost their tempers before arriving at correct views 
of the matter. In a tavern at Nashville Jackson undertook to horsewhip Benton, and in the ensuing scuffle the latter was pitched downstairs, while Jackson got a bullet in the left shoulder which he carried for more than twenty years. Jackson and Benton had been warm friends. After this affair they did not meet again until I823, when both were in the United States Senate. They were both as frank and generous as they were impulsive, and soon became fast friends again. There is an amusing side to the primitive Homeric boisterousness of such scenes among grown-up men of high station in life. In the early part of this century, though quite characteristic of the Southwest, it was not confined to that part of the country. It was not so many years since two congressmen, Matthew Lyon of Vermont and Roger Griswold of Connecticut, had rolled on the floor of the House of Representatives, cuffing and pounding each other like angry schoolboys.

The war with Great Britain was complicated with an Indian war which could not in any case have been avoided. The westward progress of the white settlers toward the Mississippi River was gradually driving the red man from his hunting-grounds; and the celebrated Tecumseh had formed a scheme, quite similar to that of Pontiac fifty years earlier, of uniting all the tribes between Florida and the Great Lakes in a grand attempt to drive back the white men. This scheme was partially frustrated in the autumn of $18 \mathrm{II}$, while Tecumseh was preaching his crusade among the Cherokees, Creeks, and Seminoles. During his absence his brother, known as the Prophet, attacked General Harrison at Tippecanoe and was overwhelmingly defeated. 
The war with Great Britain renewed Tecumseh's opportunity, and his services to the enemy were extremely valuable until his death in the battle of the Thames. Tecumseh's principal ally in the South was a half-breed Creek chieftain named Weathersford. On the shore of Lake Tensaw, in the southern part of what is now Alabama, was a stockaded fortress known as Fort Mimms; there many of the settlers had taken refuge. On the 3 oth of August, I8I3, this stronghold was surprised by Weathersford at the head of one thousand Creek warriors, and more than four hundred men, women, and children were most atrociously massacred. The news of this dreadful affair aroused the people of the Southwest to vengeance; men and money were raised by the state of Tennessee; and, before he had fully recovered from the wound received in the Benton affray, Jackson took the field at the head of twenty-five hundred men. Now for the first time he had a chance to show his wonderful military capacity, his sleepless vigilance, untiring patience, and unrivalled talent as a leader of men. The difficulties encountered were formidable in the extreme. In that frontier wilderness the business of the commissariat was naturally ill managed, and the men, who under the most favourable circumstances had little idea of military subordination, were part of the time mutinous from hunger. More than once Jackson was obliged to use one-half of his army to keep the other half from disbanding. In view of these difficulties the celerity of his movements and the force with which he struck the enemy were truly marvellous. The Indians were badly defeated at Tallasahatchee and Talladega. At length, on the 27 th of March, I8I4, having been reënforced by a regiment 
of United States infantry, Jackson struck the decisive blow at Tohopeka, otherwise known as the Horseshoe Bend of the Tallapoosa River. In this bloody battle no quarter was given, and the strength of the Creek nation was finally broken. Jackson pursued the remnant to their place of refuge, called the Holy Ground, upon which the medicine men had declared that no white man could set foot and live. Such of the Creek chieftains as had not fled to Florida now surrendered. The American soldiers were ready to kill Weathersford in revenge for Fort Mimms, but the magnanimous Jackson spared his life and treated him so well that henceforth he and his people remained on good terms with the white men. Among the officers who served under Jackson in this remarkable campaign were the two picturesque men who in later years played such an important part in the history of the Southwest, Samuel Houston and David Crockett. The Creek War was one of critical importance. It was the last occasion on which the red men could put forth sufficient power to embarrass the United States government. More than any other single battle, that of Tohopeka marks the downfall of Indian power on this continent. Its immediate effects upon the war with Great Britain were very great. By destroying the only hostile power within the Southwestern territory, it made it possible to concentrate the military force of the border states upon any point, however remote, that might be threatened by the British. More specifically, it made possible the great victory at New Orleans. Throughout the whole of this campaign, in which Jackson showed such indomitable energy, he was suffering from illness such as would have kept 
any ordinary man groaning in bed, besides that for most of the time his left arm had to be supported in a sling. His pluck was equalled by his thoroughness. Many generals after victory are inclined to relax their efforts; not so Jackson, who followed up every success with furious persistence, and whose admirable maxim was that in war " until all is done nothing is done."

On the 3 Ist of May, I8I4, Jackson was made majorgeneral in the regular army, and was appointed to command the Department of the South. It was then a matter of dispute whether Mobile belonged to Spain or to the United States. In August Jackson occupied the town and made his headquarters there. With the consent of Spain the British were using Florida as a base of operations, and had established themselves at Pensacola. Jackson wrote to Washington for permission to attack them there, but the government was loath to sanction an invasion of Spanish territory until the complicity of Spain with our enemy should be proved beyond cavil. The letter from Secretary Armstrong to this effect did not reach Jackson. The capture of Washington by the British prevented his receiving orders and left him to act upon his own responsibility, a kind of situation from which he was never known to flinch. On September 14 the British advanced against Mobile, but in their attack upon the outwork, Fort Bowyer, they met with a disastrous repulse. They retreated to Pensacola, whither Jackson followed them with three thousand men. On the 7 th of November he stormed that town. His next move would have been against Fort Barrancas, six miles distant, at the mouth of the harbour.

By capturing this post he would have entrapped the 
British fleet and might have compelled it to surrender; but the enemy forestalled him by blowing up the fort and beating a precipitate retreat. For thus driving the British from Florida, a most necessary and useful act, Jackson was stupidly and maliciously blamed by the Federalist newspapers. After clearing the enemy away from this quarter, he found himself free to devote all his energies to the task of defending New Orleans; and there, after an arduous journey, he arrived on the 2d of December. The British expedition directed against that city was much more formidable than any other that we had to encounter during that war; and, moreover, its purpose was much more deadly. In the North the British warfare had been directed chiefly toward defending Canada and gaining such a foothold upon our frontier as might be useful in making terms at the end of the war. The burning of Washington was an exasperating insult, but its military importance was very slight. But the expedition against New Orleans was intended to make a permanent conquest of the lower Mississippi, and to secure for Great Britain in perpetuity the western bank of the river. Napoleon had sold us the vast Louisiana territory in order to keep Great Britain from seizing it. As part of his empire it was a vulnerable spot which the mistress of the seas could strike with impunity so far as he was concerned. He preferred to put it into the hands of a power which was at that time hostile toward Great Britain. But the latter power felt quite competent to take it away from Napoleon's ally, and as the emperor had just been dethroned and sent to Elba, the whole strength of England, if needed, could be put forth against the United States. The war had now lasted more than 
two years, and in spite of our glorious naval victories, the American arms upon land had made but little headway as against the British. For constructive statesmanship Mr. Madison's abilities were of the highest order, but as President he had shown himself unequal to the task of conducting a war. At the outset the Americans had entertained hopes of conquering Canada, but we had begun with serious defeats and losses, and at length, after several brilliant victories, had done little more than to ward off invasion at the two gateways of Niagara and Lake Champlain. In New England the British had seized and held the wilderness east of the Penobscot, creating quite a panic throughout that part of the country. The leaders of the old Federalist party in New England were factious and disloyal, and in this very month of December, I8 I 4 , there was assembled at Hartford a convention which adopted measures looking toward a possible dissolution of the Union. The national finances were in a state of collapse, and nearly all the banks in the Middle and Southern states had suspended specie payments. The British government assumed a tone of more than ordinary arrogance. It was going to demand a high price for peace: the eastern half of Maine, at any rate, and the Michigan territory, and perhaps yet more of the Northwest; and the Americans must promise not to keep any more armed vessels upon the lakes, which must have sounded queer to Perry and Macdonough. Then, with the western bank of the Mississippi secured, Great Britain could hem in the United States, as France had once hemmed in the colonies; Canada and Louisiana could be made to join hands again. In order to effect all this, it seemed necessary to inflict 
upon the Americans one crushing and humiliating defeat, - such a defeat, for instance, as the French had lately suffered at Vitoria. That this could be done few Englishmen doubted, and so confident was the expectation of victory that governors and commandants for the towns along the Mississippi River were actually appointed and sent out in the fleet! The situation, so far as British intentions went, was thus extremely threatening. Even had nothing of all this been accomplished beyond the conquest of New Orleans, when we remember what annoyance so weak a nation as Spain had been able to inflict upon us during the twenty years preceding 1803 , we can imagine how insufferable it would have been had the mouth of the Mississippi passed under the control of the greatest naval power in the world.

When Jackson rode into New Orleans on the $2 \mathrm{~d}$ of December, 1814 , he was so worn out by disease and so jaded by his long journey in the saddle that the fittest place for him was the hospital, and almost any other man would have gone there. But in the hawklike glare of his eye there shone forth a spirit as indomitable as ever dwelt in human frame. His activity during the following weeks was well-nigh incredible. There was one time when he is said to have gone five days and four nights without sleep. Before his arrival there was dire confusion and consternation, but his energy soon restored order, and there was something in his manner that inspired confidence. He never for a moment admitted the possibility of defeat, he never doubted, fumbled, or hesitated, but always saw at a glance the end to be reached, and went straight toward it without losing a moment. At first it rather 
took people's breath away when upon his own responsibility he put the city under martial law. But an autocrat upon whom so much reliance was placed found ready obedience, and the strictest discipline was maintained. Women are apt to be quick in recognizing the true hero, and from the outset all the women of New Orleans had faith in Jackson. His stately demeanour and graceful politeness were much admired. On the day of his arrival Edward Livingston, who was now to be his aide-de-camp, invited him home to dinner. The beautiful Mrs. Livingston was then the leader of fashionable society in New Orleans. That day she had a dozen young ladies to dinner, and just as they " were about to sit down there came the startling news that General Jackson was on his way to join the party. There was anxious curiosity as to how the uncouth queller of Indians would look and behave. When he entered the room, tall and stately in his uniform of blue cloth and yellow buckskin, all were amazed at his courtly manners. and it was not long before all were charmed with his pleasant and kindly talk. After dinner he had no sooner left the house than the young ladies in chorus exclaimed to Mrs. Livingston: "Is this your backwoodsman? Why, madam, he is a prince!"1 Many years afterward Josiah Quincy, member of a committee for receiving President Jackson on his visit to Boston, was in like manner astonished at his urbanity and grace. He had the dignity that goes with entire simplicity of nature, and the ease that comes from unconsciousness of self.

One of Jackson's latest biographers observes that in this campaign everything fell out favourably for him,

${ }^{1}$ Parton, II. 3 I. 
"as if by magic." 1 But if there was any magic in the case, it lay in the bold initiative by which he got the game into his own hands and kept it there. As soon as he heard of the landing of the British, he went forth to attack them, rightly believing that their ignorance of the country might be set off against their superb discipline. He made a spirited night attack upon their camp, while from the river the heavy guns of the schooner Carolina raked them with distressing charges of grape. The effect was to check the enemy's progress and give Jackson time to complete his intrenchments in a very strong position which he had chosen, near the Bienvenue and Chalmette plantations, on the east side of the river. On the farther side he placed. the militia of Kentucky and Louisiana, under General Morgan. The British numbered twelve thousand men under command of Wellington's brother-in-law, the gallant Sir Edward Pakenham. To oppose these veterans of the Spanish peninsula, Jackson had six thousand of that sturdy race whose fathers had vanquished Ferguson at King's Mountain, and whose children so nearly vanquished Grant at Shiloh. On the 8th of January Pakenham was unwise enough to try to overwhelm his adversary by a direct assault all along the line. It was repeating Bunker Hill and anticipating Cold Harbor. On the west bank, indeed, the British weight of numbers prevailed, pushed the militia out of the way, and seemed to open a chance for turning Jackson's position. But all this was rendered futile by the stupendous catastrophe on the eastern bank. "Don't waste any shots, boys," said Jackson, as the long lines of redcoats were seen approaching, "make 
every shot tell; we must finish this business to-day, you know." We may well believe that these faultless marksmen, who thought nothing of bringing down a squirrel from the top of the tallest tree, wasted very few shots indeed. In just twenty-five minutes the British were in full retreat, leaving twenty-six hundred of their number killed and wounded. "The field," said an officer, "was so thickly strewn with the dead, that from the American ditch you could have walked forward for a quarter of a mile on the bodies." "In some places whole platoons lay together, as if killed by the same discharge." 1 Without a sound of exultation the Americans looked on the dreadful scene in melancholy silence, and presently detachments of them were busy in assuaging the thirst and bathing the wounds of those in whom life was left. Among the slain was Pakenham himself. The American loss was only eight killed and thirteen wounded, because the enemy were mown down too quickly to return an effective fire. Never, perhaps, in the history of the world, has a battle been fought between armies of civilized men with so great a disparity of loss. It was also the most complete and overwhelming defeat that any English army has ever experienced. It outdid even Bannockburn. News travelled so slowly then that this great victory, like the three last naval victories of the war, occurred after peace had been made by the commissioners at Ghent. Nevertheless, no American can regret that the battle was fought. Not only the insolence and rapacity of Great Britain had richly deserved such castigation, but if she had once gained a foothold in the Mississippi Valley, it might have taken an armed

${ }^{1}$ Parton, II. 209. 
force to dislodge her, in spite of the treaty; for in the matter of the western frontier posts after I 783 she had by no means acted in good faith. Jackson's victory decided that henceforth the Mississippi Valley belonged indisputably to the people of the United States. It was the recollection of that victory, along with the exploits of Hull and Decatur, Perry and Macdonough, which caused the Holy Alliance to look upon the Monroe Doctrine as something more than an idle threat. All over the United States the immediate effect of the news was electric; and it was enhanced by the news of peace which arrived a few days later. By this "almost incredible victory," as the National Intelligencer called it, the credit of the American arms, upon land, was fully restored. Not only did the administration glory in it, as was natural, but the opposition lauded it for a different reason, as an example of what American military heroism could do in spite of inadequate support from government. Thus praised by all parties, Jackson, who before the Creek War had been little known outside of Tennessee, became at once the foremost man in the United States. People in the North, while throwing up their hats for him, were sometimes heard to ask: "Who is this General Jackson? To what state does he belong?" Henceforth, until the Civil War, he occupied the most prominent place in the popular mind.

After his victory Jackson remained three months in New Orleans, in some conflict with the civil authorities of the town, which he found it necessary to hold under martial law. In April he returned to Nashville, still retaining his military command of the Southwest. He soon became involved in a quarrel 
with Mr. Crawford, the Secretary of War, who had undertaken to modify some provisions in his treaty with the Creeks. Jackson was also justly incensed by the occasional issue of orders from the War Department directly to his subordinate officers; such orders sometimes stupidly thwarted his plans. The usual course for a commanding general thus annoyed would be to make a private representation to the government. But here, as ordinarily, while quite right in his position, Jackson was violent and overbearing in his methods. He published, April 22, I8I7, an order forbidding his subordinate officers to pay heed to any order from the War Department unless issued through him. Mr. Calhoun, who in October succeeded Crawford as Secretary of War, gracefully yielded the point, but the public had meanwhile been somewhat scandalized by the collision of authorities. In private conversation General Scott had alluded to Jackson's conduct as savouring of mutiny. This led to an angry correspondence between the two generals, ending in a challenge from Jackson, which Scott declined on the ground that duelling is a wicked and unchristian custom.

Affairs in Florida now demanded attention. That country had become a nest of outlaws, and chaos reigned supreme there. Many of the defeated Creeks had found a refuge in Florida; and runaway negroes from the plantations of Georgia and South Carolina were continually escaping thither. During the late war British officers and adventurers, acting on their own responsibility upon this neutral soil, committed many acts which their government would never have sanctioned. They stirred up Indians and negroes to 
commit atrocities on the United States frontier. The Spanish government was at that time engaged in warfare with its revolted colonies in South America, and the coasts of Florida became a haunt for contraband traders, privateers, and filibusters. One adventurer would announce his intention to make Florida a free republic; another would go about committing robbery on his own account; a third would set up an agency for kidnapping negroes on speculation. The disorder was hideous. On the Apalachicola River the British had built a fort, and amply stocked it with arms and ammunition, to serve as a base of operations against the United States. On the departure of the British, the fort was seized and held by negroes. This alarmed the people of Georgia, and in July, I816, United States troops, with permission from the Spanish authorities, marched in and bombarded the negro fort. A hot shot found its way into the magazine, three hundred negroes were blown into fragments, and the fort was demolished. In this case the Spaniards were ready to leave to United States troops a disagreeable work for which their own force was incompetent. Every day made it plainer that Spain was quite unable to preserve order in Florida, and for this reason the United States entered upon negotiations for the purchase of that country. Meanwhile the turmoil increased. White men were murdered by Indians, and United States troops under Colonel Twiggs captured and burned a considerable Seminole village known as Fowltown. The Indians retaliated by a wholesale massacre of fifty people who were ascending the Apalachicola River in boats; some of the victims were tortured with firebrands. Jackson 
was now ordered to the frontier. He wrote at once to President Monroe, "Let it be signified to me through any channel (say Mr. John Rhea) that the possession of the Floridas would be desirable to the United States, and in sixty days it will be accomplished." Mr. Rhea was a representative from Tennessee, a confidential friend of both Jackson and Monroe. The President was ill when Jackson's letter reached him, and does not seem to have given it due consideration. On referring to it a year later he could not remember that he had ever seen it before. Rhea, however, seems to have written a letter to Jackson, telling him that the President approved of his suggestion. As to this point the united testimony of Jackson, Rhea, and Judge Overton seems conclusive. Afterward Mr. Monroe, through Rhea, seems to have requested Jackson to burn this letter, and an entry on the general's letter-book shows that it was accordingly burnt, April I2, I8I9. There can be no doubt that, whatever the President's intention may have been, or how far it may have been correctly interpreted by Rhea, the general honestly considered himself authorized to take possession of Florida on the ground that the Spanish government had shown itself incompetent to prevent the denizens of that country from engaging in hostilities against the United States. Jackson acted upon this belief with his accustomed promptness. He raised troops in Tennessee and neighbouring states, invaded Florida in March, I818, captured St. Mark's, and pushed on to the Seminole headquarters on the Suwanee River. In less than three months from this time he had overthrown the Indians and brought order out of chaos. His measures were 
praised by his friends as vigorous, while his enemies stigmatized them as high-handed. In one instance his conduct was certainly open to question. At St. Mark's his troops captured an aged Scotch trader and friend of the Indians, named Alexander Arbuthnot; near Suwanee, some time afterward, they seized Robert Ambrister, a young English lieutenant of marines, nephew of the governor of New Providence. Jackson believed that these men had incited the Indians to make war upon the United States and were now engaged in aiding and abetting them in their hostilities. They were tried by a court-martial at St. Mark's. On evidence which surely does not to-day seem fully conclusive, Arbuthnot was found guilty and sentenced to be hanged. Appearances were more strongly against Ambrister. He did not make it clear what his business was in Florida, and threw himself upon the mercy of the court, which at first condemned him to be shot, but on further consideration commuted the sentence to fifty lashes and a year's imprisonment. Jackson arbitrarily revived the first sentence, and Ambrister was accordingly shot. A few minutes afterward Arbuthnot was hanged from the yard-arm of his own ship, declaring with his last breath that his country would avenge him. In this affair Jackson unquestionably acted from a stern sense of duty; as he himself said, "My God would not have smiled on me had I punished only the poor, ignorant savages, and spared the white men who set them on." Here, as on some other occasions, however, when under the influence of strong feeling, it may be doubted if he was to the full extent capable of estimating evidence. It is, however, very probable that the men were guilty. 
On his way home, hearing that some Indians had sought refuge in Pensacola, Jackson captured the town, turned out the Spanish governor, and left a garrison of his own there. He had now virtually conquered Florida, but he had moved rather too fast for the government at Washington. He had gone further, perhaps, than was permissible in trespassing upon neutral territory; and his summary execution of two British subjects aroused furious excitement in England. For a moment we seemed on the verge of war with Great Britain and Spain at once. Whatever authority President Monroe may have intended, through the Rhea letter, to confer upon Jackson, he certainly felt that the general had gone too far. With one exception all his cabinet agreed with him that it would be best to disavow Jackson's acts and make reparation for them. But John Quincy Adams, Secretary of State, was in point of boldness not unlike Jackson. He felt equal to the task of dealing with the two foreign powers, and upon his advice the administration decided to assume the responsibility for what Jackson had done. Pensacola and St. Mark's were restored to Spain, and an order of Jackson's for the seizing of St. Augustine was countermanded by the President. But Adams represented to Spain that the American general, in his invasion of Florida, was virtually assisting the Spanish government in maintaining order there; and to Great Britain he justified the execution of Arbuthnot and Ambrister on the ground that their conduct had been such that they had forfeited their allegiance and become virtual outlaws. Spain and Great Britain accepted the explanations; had either nation felt in the mood for war with 
the United States, it might have been otherwise. As soon as the administration had adopted Jackson's measures, they were for that reason attacked in Congress by Clay, whose opposition was at this time factious, and this was the beginning of the bitter and lifelong feud between Jackson and Clay. In I8 19 the purchase of Florida from Spain was effected, and in I 82 I Jackson was appointed governor of that territory.

The victorious general was now in his fifty-fifth year. Until the age of forty-five he had been little known outside of Tennessee. It was then that the Creek War gave him his opportunity, and revealed the fact that there was a great general among us. Since the battle of New Orleans he had come to be as much a hero in America as Wellington in England. The Iron Duke was never once defeated in battle, but if he had ever come to blows with Old Hickory, I do not feel absolutely sure that the record might not have been broken. Jackson's boldness and tenacity were combined with a fertility in resources that made him, like Boots in the fairy tales, everywhere invincible. Alike in war and in politics we already begin to see him always carrying the day. One can see that the election of such a man to the presidency would be likely to mark an era in American history. One sees in Jackson a representative man. His virtues and his faults were largely those of the frontier society that in those days lived west of the Alleghanies. His election to the presidency was the first great political triumph of that Western country which Gouverneur Morris wished to see always kept in leading-strings. The significance of this triumph I shall try to point out in my next paper. 
Note. An Unpublished Letter of Andrew Jackson.

Through the courtesy of the late Colonel Thomas Tasker Gantt of St. Louis, Missouri, Dr. Fiske's attention was directed to an unpublished letter of Jackson's, written by the general in 1818 to his friend, the Hon. G. W. Campbell, minister to Russia, concerning affairs in Florida. Dr. Fiske made an exact copy, which is given below, an interesting example, not only of the writer's virility of expression, but of his well-known peculiarities of spelling. Of these peculiarities General Jackson was himself well aware. That he was also drolly indifferent to all conventional rules of orthography appears from an extract of correspondence between Colonel Gantt and Mrs. Elizabeth B. Lee, daughter of the distinguished Virginian, Francis P. Blair, and sister to Montgomery Blair of Lincoln's cabinet. From the lifelong intimacy of the Blairs and the Jacksons, Mrs. Lee was often, as a girl, a guest at "The Hermitage" and at the White House. "Once," she writes, "when copying a letter for him I protested against his spelling which three different ways on one page and wanted him to alter it, but he would not, and said laughingly that he could make himself understood, and that as I was a copyist, I had better spell it as I found it; then he added, more seriously, that at the age when most young people learn to spell he was working for his living and helping the best of mothers."

\section{$D^{r} \operatorname{Sir}$}

\section{Chekesaw Nation Treaty Ground,} $\mathrm{Oct}^{\mathrm{r}} 5^{\text {th }}$ 18 8 .

I know you will be astonished at receiving an answer to your very friendly letter of the $22^{\mathrm{d}}$ July last at this distant day and from this place. Your letter came to hand by due course of mail, but found me sick in bed - that I could not comply with your request or my own wishes by giving it a speedy answer. It was some time before I recovered so as to use a pen, and when I did, I found myself surrounded by letters and communications relative to my official duties that occupied my whole time that I was able to attend to business untill the arrival of Governor Shelby of Kentucky with whom I was joined in commission to hold a treaty with this nation for a surrender of their right to all lands within 
the states of Tennessee and Kentucky. We arrived here on the $29^{\text {th }}$ ult. and found everything wrong: an agent unacquainted with Indians, the geography of the country, or even what was the wishes of the government, and not half the nation notified of the time or place of meeting. Runners have gone to all parts of the nation to collect them : we are waiting their arrival and I am thereby afforded a leisure moment to answer your friendly letter.

It affords me much pleasure to see the polite attention of the eastern people towards you. This shows a spirit of harmony towards the southern and western people that I hope will grow into permanent harmony between the two interests, and that violence of party spirit and bickering will cease to exist in our happy country.

On the subject of my taking Pensacola I regret that the Government had not furnished you with a copy of my report from Fts Gadsden and Montgomery. This would have given you a full view of the whole ground. You are advised of the situation of our southern frontier when I was ordered to take the field and put a speedy end to the conflict with the Seminoles, \&c., \&c. Our frontier when I reached it was reeking with the blood of our women and children and the masacre of Lt. Scott. When I reached Ft. Scott I found it out of supplies and no alternative left me but to abandon the campaign, or to force my way to the bay of Appalachicola and risque meeting supplies I had ordered from N. Orleans. I chose the latter - and succeeded. Having obtained eight days rations for my men I immediately marched on Muckasookey, where the strength of the enemy was collected, first apprising the Governor of Pensacola why I had entered the Floridas, to wit, not as the enemy but as the friend of Spain; as Spain had acknowledged her incapacity, through her weakness to control the Indians within her terrritory and keep them at peace with the United States, self-defence justified our entering her territory and doing that for her which she had bound herself to do by solem treaty - that as I was engaged fighting the battles of Spain I had a right and did calculate on receiving all the facilities in the power of the agents of Spain that would aid me in putting a speedy end to the war; advising the Governor in the same letter that I had ordered supplies up the for my army to Ft Crawford, which I trusted would be permitted to pass unmolested 
without any delay occasioned by the agents of Spain, but should I be disappointed in my expectation of the friendly dispositions of the agents of Spain, or should my supplies be interrupted by them, I SHOULD VIEW IT AS AN ACT OF WAR AND TREAT IT ACCORDINGLY. I received in answer to this friendly letter a positive declaration that my provisions should not pass; the supplies were by the Governor seized at Pensacola under a demand of transit duties, and my whole army thereby made subject to starvation, and which I never got until I entered Pensacola. I proceeded against Muckasookey, routed and dispersed the enemy, taking some prisoners from whom I learned that the Indians received all their supplies of ammunition from Ft Marks thirty miles distant, and that the noted and notorious Francis the prophet and his party had retired to St. Marks with all his booty taken from Ft Scott; and Inchqueen and his party had retired there also - that the ballance of the Indians had fled to the negroes on the Sewanney [Suwanee] river. I was also informed by the Governor of Pensacola, through captains Call and Gordon, that he expected Ft Marks was in the hands of the Indians and negroes, as they had made demand of large supplies which the commander was not able to comply with, and he was unable to defend the fort. As soon as I had collected the corn and cattle for the supply of my troops, I marched on Ft Marks - when I reached there I found that Francis and party had been in the fort, that the garrison had been supplied with the cattle stolen from our frontier, that our public stores were the granaries of our enemy, and that the Indians had been supplied with all of munitions of war by the commandant - and that the notorious Arbuthnot was then in the garrison. I demanded possession of the garrison to be possessed by my troops during the war, and untill Spain could reinforce it with as many troops as would insure the safety of our frontier and a fulfillment of the treaty with the U States on the part of Spain. This was refused me. I saw across St. Marks river the smoke of my enemy; delay was out of the question. I seized Arbuthnot in the garrison and took possession of it. The noted Francis, who had just returned with a brigadier general's commission, a good rifle and snuff-box presented by the Prince Regent, had been captured the day before with four of his followers by Capt. McKeever whose vessell they had visitted, mistaking it for a vessell expected from 
England with supplies for the Indians, as he stated. I ordered him this principle chief to be hung, and marched the next day for Sewanney, where I routed the Indians and negroes, took Ambrister, a British officer who headed the negroes, Arbuthnot's schooner with all their papers, which led to the conviction and execution of Arbuthnot and Capt. Ambrister, both of whom was executed under sentence of a court-martial at Ft. Marks. I returned to Ft Gadsden, where preparing to disband the militia force I rec information that four hundred and fifty Indians had collected in Pensacola, was fed by the Governor, and a party furnished by the governor had issued forth and in one night slaughtered eighteen of our citizens, and that another party had, with the knowledge of the governor, and being furnished by him, went out publickly, murdered a Mr. Stokes and family, and had in open day returned to Pensacola and sold the booty, amongst which was the clothing of Mr. Stokes. This statement was corroborated by a report of Gov. Bibb. I was also informed that the provisions I had ordered for the supply of Ft Crawford and my army on board the U. States schooner Amelia was seized and detained at Pensacola with a small detachment of regulars and six hundred Tennesseans. I marched for Pensacola; whilst on my march thither I was met by a protest of the governor of Pensacola, ordering me out of the Floridas, or he would oppose force to force and drive me out of the territory of Spain. This bold measure of the governor, who had alleged weakness as the cause of his non-fulfillment of the treaty with the U. States, when united with the facts stated, of which I then had positive proof - that at that time a large number of the hostile Indians were then in Pensacola, who I had dispersed east of the Appalachicola - unmasked the duplicity of the governor and his having aided and abetted the Indians in the war against us. I hastened my steps, entered Pensacola, took possession of my supplies. The governor had fled from the city to the Barancas, where he had strongly fortified himself. I demanded possession of the garrison to be held by American troops until a guarantee should be given for the fulfillment of the treaty and the safety of the frontier. This was denyed. I approached the Barancas with one $9^{1 \mathrm{~b}}$ piece and $5 \frac{8}{10}$ inch howitzer. They opencd their batteries upon me. It was returned spiritedly and with two pieces against forty odd mounted of 24 [pounders?] the white flag 
went up in the evening and the capitulation entered into, which you have seen. It is true I had my ladders ready to go over the wall which I believe the garrison discovered and was afraid of a night attack and surrendered. When the flag was hoisted the [y] had three hundred effectives in the garrison - this number of Americans would have kept it from combined Urope [Europe]. There was one Indian wounded in the garrison and the others were sent out in the night across the bay before I got possession. Thus Sir I have given you a concise statement of the facts and all I regret is that I had not stormed the works, captured the governor, put him on his trial for the murder of Stokes and his family, and hung him for the deed. I could adopt no other way to "put an end to the war" but by possessing myself of the stronghold that was an asylum to the enemy and afforded them the means of offence. The officers of Spain having by their acts identified themselves with our enemy, became such, and by the law of nations subjected themselves to be treated as such. Self defence justified me in every act I did. I will stand justified before God and all Urope, and I regret that our government has extended the courtesy to Spain of withdrawing the troops from Pensacola before Spain gave a guarantee for the fulfilment of the treaty and the safety of our frontier. It was an act of courtesy that nothing but the insignificance and weakness of Spain can excuse, but it is not my province to find fault with the acts of the government, but it may have reason to repent of her clemency.

Make a tender to your lady of my sincere respects and best wishes for her happiness and receive Sir for yourself an expression of my unfeigned frendship and esteem - and - $[\mathrm{I}]$ remain respectfully

Yr. mo. ob. serv.

P. S. My eyes are weak and my Andrew Jackson. hand trembles I am still weak and much debilitated Nothing but the hope of being serviceable to the wishes of my government and interest of the state of Tennessee could have induced me to have undertaken the journey. A. J.

The Honble

G. W. Campbell

Minister at Russia 
Endorsed by Mr. Campbell - "Gen. Andrew Jackson, Chickasaw Nation, 5 Oct. 1818

$$
\operatorname{Rec}^{d} \frac{25 \operatorname{Dec}^{r}}{7 \operatorname{Jan}^{y}} \text { 1818-19 }
$$

Giving an account of the taking possession of Pensacola." ans $^{d}$ 8. Sept. r8rg.

This letter was given by Major Campbell Brown of Spring Hill, Tennessee (a grandson, I think, of G. W. Campbell), to Colonel Gantt; and Colonel Gantt gave it to the Mercantile Library of St. Louis, where it is to be found. - JoHn Fiske. 


\section{VII}

\section{ANDREW JACKSON}

AND AMERICAN DEMOCRACY SEVENTY YEARS AGO 



\section{VII}

\section{ANDREW JACKSON}

AND AMERICAN DEMOCRACY SEVENTY YEARS AGO

THE period comprised between the years I 8 I 5 and I 860 - between our second war with England and our great Civil War - was the period in which American society was more provincial in character than at any time before or since. By provincialism I mean the opposite of cosmopolitanism; I refer to the state of things in which the people of a community know very little about other communities and care very little for foreign ideas and foreign affairs. I do not mean to imply that the community thus affected with provincialism is necessarily backward in its civilization. Provincialism is, indeed, one of the marks of backwardness, but it is a mark that is often found in the foremost communities. No one doubts that England and France stand in the front rank among civilized nations; but when a Frenchman in good society thinks that the people of the United States talk Spanish, or when a college-bred man in England imagines Indians in feathers and war-paint prowling in the backwoods near Boston, none can doubt that they are chargeable with provincialism in a very gross form indeed. This sort of dense ignorance is apt to underlie national antipathies, and when manifested between the different parts of a common country it is accountable for what we 
call sectional prejudice. Such antipathies are usually ill founded. That human nature which we all possess in common is very far from perfect, but after all it is encouraging to find, as a general rule, that the better we understand people the more we like them. If all the bitterness, all the quarrels and bloodshed, that have come from sheer downright ignorance were to be eliminated from the annals of mankind, those annals would greatly shrink in volume. It is, therefore, devoutly to be wished that provincialism may by and by perish, and every encouragement should be given to the agencies which are gradually destroying it, such as literature, commerce, and travel, enabling the people of different countries to exchange ideas and learn something about each other's characters.

American provincialism sixty years ago, however, had something about it that was wholesome. A great many bad things have their good sides, and in looking back upon evils that we have got rid of, we can sometimes see that they did something toward checking other evils. An exceedingly foolish and barbarous custom was duelling; but it doubtless served somewhat to restrain that graceless impudence which sometimes seems threatening in turn to become a national misfortune. So with provincialism; it had its good side in so far as it was a reaction against the old colonial spirit which kept our minds in thraldom to Europe, and especially to England, long after we had by force of arms achieved political independence. Before the Revolutionary War we were kept perpetually reminded of England. Most of the colonial governors and revenue officers, and many of the judges, received their appointments from London. Every change of 
ministry was fraught with possibilities affecting our welfare. Our seaports were familiar with the sight of British officials. We depended upon England for fine arts and fashions, as well as for a great many of the manufactured articles in common use. We read British historians and essayists, quoted British poets, and taught our children out of British text-books. We felt that the centre of things was in Europe, while we were comparatively raw communities on the edge of a vast continent, much of which was still unexplored and the greater part of it a wilderness possessed by horrid savages. This state of feeling lasted for some time after the Revolution. For a quarter of a century our political contests related quite as much to foreign as to domestic questions. The horrors of the French Revolution made the Federalists an English party; they looked upon England as the guardian of law and order in Europe. The Republicans, on the other hand, applauded the overthrow of a miserable despotism and sympathized with the ideas of revolutionary France. They accused the Federalists of leanings toward monarchy; they called them aristocrats and snobs, and thought it very mean in them to turn a cold shoulder to the people who had helped us win our independence. But it was not merely a question of our sympathies; we were really forced into taking sides. During nearly the whole of this period France and England were at war with each other, and in accordance with the barbaric system then prevalent, their privateers preyed upon the shipping of neutral nations. As we had not then discovered how to protect ships out of existence, we did a very large and profitable carrying trade. Our ships were the best in the world, and no other neutral 
nation, unless it may have been Holland, had so many on the ocean. This fact kept foreign politics in the foreground until the culmination of the long quarrel was reached in the War of I8I2-I8I5. That war has been called, with much propriety, our second war of independence. It taught other nations that we were not to be insulted with impunity, and it set our politics free from European complications. The year I8I5 marks an epoch on both sides of the Atlantic. It was the beginning of thirty years of peace, during which, in America as in England, attention could be devoted to political and social reforms. Great and exciting questions of domestic politics soon came up to occupy the attention of Americans, and their thoughts were much less intimately concerned with what people were saying and doing on the other side of the ocean. We also paid less attention to European manners and fashions. Our statesmen of the Revolutionary period dressed very much like Englishmen, and since the Civil War it is so again. But in the intermediate period, between I 815 and I 860 , we had the bright blue coat with brass buttons and the buff waistcoat, such as Daniel Webster used to wear when he made those immortal speeches that did so much to enkindle a passionate love for the Union and make it strong enough to endure the shock of war. That blue dress-coat with brass buttons was the visible symbol of the period of narrow, boastful, provincial, but wholesome and muchneeded, Americanism.

Now, this feeling of Americanism grew up more rapidly and acquired greater intensity in the new states west of the mountains than in the old states on the seaboard. Observe the surprising rapidity 
with which these new states were formed, as the obstacles to migration were removed. The chief obstacles had been the hostility of the Indians, and the difficulty of getting from place to place. During the late war the Indian power had been broken by Harrison in the North and by Jackson ${ }^{1}$ in the South. In 1807 Robert Fulton had invented the steamboat. In I 8 I I a steamboat was launched on the Ohio River at Pittsburg, and presently such nimble craft were plying on all the Western rivers, carrying settlers and traders, farm produce and household utensils. This gave an immense impetus to the Western migration. After Ohio had been admitted to the Union in 1802 , ten years had elapsed before the next state, Louisiana, was added. But in six years after the war a new state was added every year: Indiana in 1816 , Mississippi in 1817 , Illinois in 1818 , Alabama in 1819 , Maine in 1820 , Missouri in 1821 ; all but one of them west of the Alleghanies, one of them west of the Mississippi. In President Monroe's second term, while there were thirty senators from the Atlantic states, there were already eighteen from the West. It was evident that the political centre of gravity was moving westward at a very rapid rate.

In the new Southern states thus created below the thirty-sixth parallel the South Carolinian type of society prevailed. In all the others there was an extensive and complicated mixing of people from different Atlantic states. Toward I 840, after Ericsson's

1 "It has been pleasant too to revise many of my ideas and opinions : for my youthful memories go back to the days when Jackson was like a bogy to frighten naughty children ! Boston was a place of one idea then." Extract from a letter of Mr. James Day to Dr. Fiske. 
invention of the screw propeller had set up the new migration of foreigners from Europe, and after the great stream of New Englanders had begun to pour into the Northwest, the mixing became still more complicated. The effect of this was excellent in shaking men's ideas out of the old ruts, in bringing together people of somewhat various habits and associations, in breaking down artificial social distinctions, in broadening the range of sympathy, and in adding to the heartiness and cordiality of manner. This new society was much more completely democratic than that of the Atlantic states, and it soon began powerfully to react upon the latter. During the period of which I am speaking most of the states remodelled or amended their constitutions in such wise as to make them more democratic. There was an extension of the suffrage, a shortening of terms of office, and a disposition to make all offices elective. There was much that was wholesome in this democratic movement, but there was also some crudeness, and now and then a lamentable mistake was made. Perhaps the worst instance was that of electing judges for limited terms instead of having them appointed for life or during good behaviour. In particular cases the system may work fairly well, but its general tendency is demoralizing to bench and bar alike, and I believe it to be one of the most crying abominations by which our country is afflicted. Taken in connection with the disposition to seek violent redress for injuries, and with the mawkish humanitarianism of which criminals are so quick to take advantage, it has done much to diminish the security of life and property and to furnish a valid excuse for the rough 
and ready methods of Judge Lynch. It is encouraging to observe at the present time some symptoms of a disposition to return to the older and sounder method of making judges. Good sense is so strongly developed among our people that we may reasonably calculate upon their profiting by hard experience and correcting their own errors in the long run. It is far better that popular errors should be corrected in this way than by some beneficent autocratic power, or by some set of people supposed to be wiser than others; and this, I believe, is the true theory of democracy. This is the vital point which Jefferson understood so much more clearly than Hamilton and the Federalists.

But in the period of which I am speaking, the theory of democracy was not usually taken so moderately as this. There was a kind of democratic fanaticism in the air. A kind of metaphysical entity called the People (spelled with a capital) was set up for men to worship. Its voice was the voice of God; and, like the king, it could do no wrong. It had lately been enthroned in America, and was going shortly to renovate the world. People began to forget all about the slow growth of our constitutional liberty through ages of struggle in England and Scotland. They began to forget all about our own colonial period, with its strongly marked characters and its political lessons of such profound significance. A habit grew up, which has not yet been outgrown, of talking about American history as if it began in 1776 , an error as fatal to all correct understanding of the subject as that which Englishmen used to make in ignoring their own history prior to the Norman Conquest. We 
began to look upon our federal Constitution as if it had been suddenly created by an act of miraculous wisdom, and had no roots in European soil. It was telt that our institutions were hedged about by a kind of divinity, and that by means of them we had become better than other nations; and, in our implicit reliance upon the infallible wisdom of the-people, we went to work at legislation and at constitution-making in a much less sober spirit than to-day. As for Europe, we exaggerated its political shortcomings most egregiously, and failed to see that it could have any political lessons for us. The expressions most commonly heard about Europe were "pauper labor" and "effete dynasties." People seldom crossed the ocean to look at things over there with their own eyes. The feeling with which children then grew up found expression a little later in such questions as, "What do we care for abroad?" A gentleman who has been speaker of the House of Representatives and major-general in the army once said in a public speech that too much time was spent in studying the history of England; we had much better study that of the North American Indians; it was quite enough to know something about the continent we live on, the rest of the world was hardly worth knowing. At one time even the pronunciation of the word European seemed in danger of being forgotten; it was quite commonly pronounced Európian.

Those were the days of spread-eagle oratory on the Fourth of July, and whenever people were assembled in public, the days when ministers in the pulpit used to thank Heaven that "in spite of all temptations to belong to other nations" we had been born Americans. 
They were the days when Elijah Pagram could silence all cavillers by reminding them that "our bright home is in the settin' sun." More summary were the methods of Mr. Hannibal Chollop. "Do you see this pistol ?" said he to Martin Chuzzlewit. "I shot a man down with it the other day in the state of Illinois. I shot him for asserting in the Spartan Portico, a triweekly journal, that the ancient Athenians went ahead of the present locofoco ticket." Very few eminent persons from England visited the United States in those days, and it was quite natural that those who did should feel called upon, after going home, to write books recording their impressions of the country and the people. Such books, even when written in a friendly spirit, were sure to give mortal offence to the Americans, simply because it was impossible for the writers, without making themselves ridiculous, to pile up superlatives enough to satisfy our national vanity. When one reads Dickens's "American Notes," in which he treats us seriously, one finds it hard to understand the storm of indignation which it aroused, except that he did indeed touch upon one very sensitive spot, the incongruity between negro slavery and our fine talk about the rights of man. In "Martin Chuzzlewit" he made fun of us; but the good-natured banter which enraged our fathers only makes us laugh to-day. Dickens was friendly, Mrs. Trollope was not. "To speak plainly," said she, "I do not like the Americans." The poor woman had entered our country by what was then one of its back doors. She had landed at New Orleans and gone up by river to Cincinnati, where circumstances obliged her to live for more than a year in the old times when countless 
pigs ran wild in the unpaved streets of the frontier town. Any one who wishes to understand American democracy sixty years ago should read her book. It is evidently a truthful account of a state of society in which very few of us would find it pleasant to live, and it is amusing to see the naïveté with which the writer's expressions become mollified as on her homeward journey she reaches Philadelphia and New York. It is noticeable that the examples of Americanism quoted by English travellers of that day were almost always taken from the West. They had very little to say about Boston because it was too much like an English town. They came in search of novelty and found it in the valley of the Mississippi, as they now find it in the Rocky Mountains.

No such novelty, however, can the European traveller find anywhere in the United States to-day as that which so astonished him half a century ago. The period of provincialism which I have sought to describe came to an end with our Civil War. The overthrow of slavery removed one barrier to the sympathy between America and western Europe. The sacrifices we had to make in order to save our country intensified our love for it, but diminished our boastfulness. In a chastened spirit we were enabled to see that even in American institutions there might be elements of weakness, that perhaps the experience of other nations might have lessons worthy of our study, and that the whole world is none too wide a field wherefrom to gather wisdom. Moreover, the railroad and telegraph, two of the mightiest agencies yet devised for hastening the millennium, have already wrought a marvellous transformation, which is but the 
harbinger of greater transformations, in the opinions and sentiments and mental habits of men and women in all civilized countries. Nowhere have the complicated effects been more potent or more marked than in the United States. Every part of our vast domain has been brought into easy contact with all four quarters of the globe. Australia and Zululand are less remote from us to-day than England was in Jackson's time. We go back and forth across the Atlantic in crowds, and we exchange ideas with the whole world. We are becoming daily more and more cosmopolitan, and are, perhaps, as much in the centre of things as any people.

However, as I said a moment ago, the old provincial spirit of Americanism was in its day eminently useful and wholesome. The swagger and tall talk was simply the bubbling forth that accompanied the fermentation of a vigorous and hopeful national spirit, but for which we might long before this have been broken up into a group of little spiteful, squabbling republics, with custom-houses and sentinels in uniform scattered along every state line. The second war with England was the first emphatic assertion of this national spirit. Before that time the sentiment of union was weak. In I 786 nearly all the states were, for various reasons, snarling and showing their teeth. In I 799 Kentucky uttered a growl in which something was heard that sounded like nullification. In 1804 Timothy Pickering dallied with a scheme, to which it was hoped that Aaron Burr might lend assistance, for a Northern confederacy of New England and New York, with the possible addition of New Jersey and Pennsylvania. In 1808 some of the New Eng- 
land Federalists, enraged at Jefferson's embargo, entertained thoughts of secession, and in I8I4 there was mischief brewing at Hartford. It was the result of the war with Great Britain that dealt the first staggering blow to these separatist tendencies. In that grand result, so far as the naval victories were concerned, the chief credit was won by New England, and it went far toward setting the popular sentiment in that part of the country out of gear with the schemes of the mossback Federalist leaders. But as regarded the land victories and the whole political situation, the chief credit accrued to the West. It was the much-loved statesman, "Harry of the West," the eloquent Henry Clay, that had prevailed upon the country to appeal to arms, in spite of the wrath of the New Englanders and the misgivings of President Madison. It was the invincible soldier of Tennessee that crowned the work with a prodigious victory. Had the war ended simply with the treaty of Ghent, which did not give us quite so much as we wanted, the discontent of New England would probably have continued. It was the battle of New Orleans that killed New England federalism. It struck a chord of patriotic feeling to which the people of New England responded promptly. The Federalist leaders were at once discredited, and not a man that had gone to the Hartford convention but had hard work, for the rest of his life, to regain the full confidence of his fellow-citizens. In the presidential election of 1816 the Federalists still contrived to get thirty-four electoral votes for Rufus King. In I 820 they did not put forward any candidate; their party was dead and buried. All but one of the electoral votes were given to James Monroe. One elector cast 
his vote for John Quincy Adams, just as a matter of form, in order that no President after Washington might be chosen by an absolutely unanimous vote.

This was what we called the "era of good feeling." The war had disposed of the old issues, and the new ones had not yet shaped themselves. As all the candidates for the election of 1824 were called Republicans, the issues between them seemed to be purely of a personal nature. There was a genuine political force at work, however, and a very strong one. This was the spirit of reaction against European ideas, the bumptious and boisterous democratic Americanism of the young West. The backwoodsmen and Mississippi traders were to be represented in the White House, in spite of Virginia planters and Harvard professors. There was a wish to put an end to what some people called the "Virginia dynasty" of Presidents; and it was with this in view that Clay kept up, during Monroe's administration, an opposition that was sometimes factious. It was, for instance, partly because Monroe had sanctioned Jackson's measures in Florida, that Clay and his friends felt bound to attack them, thus laying the foundations of the lifelong feud between Clay and Jackson. In 1823, when the latter resigned the governorship of Florida and took his seat in the United States Senate, he had already been nominated by the legislature of Tennessee as the candidate of that state for the presidency. Some of his friends, under the lead of William Lewis, had even two years earlier conceived the idea of making him President. At first General Jackson cast ridicule upon the idea. "Do they suppose," said he, "that I am such a d-d fool as to think myself fit for President of the United 
States? No, sir. I know what I am fit for. I can command a body of men in a rough way; but I am not fit to be President." Such is the anecdote told by H. M. Brackenridge, who was Jackson's secretary in Florida (Parton, II. 354). At this time the general felt old and weak, and had made up his mind to spend the remainder of his days in peace on his farm. Of personal ambition, as ordinarily understood, Jackson seems to have had much less than many other men. But he was, like most men, susceptible to flattery, and the discovery of his immense popularity no doubt went far to persuade him that he might do credit to

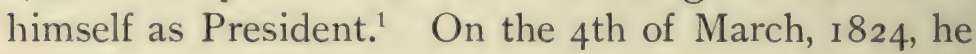

\section{Jackson, Crawford, and Adams in 1824}

(Extract from a manuscript letter of John A. Dix, dated Washington, 22d February, 1824)

"Mr. Calhoun's chances of success depended on the course of Pennsylvania. This state, it appears, will support the hero of New Orleans, and Mr. Calhoun's fate is sealed. My opinion is that the West will renounce Mr. Clay's persuasion, and will very generally support Gen. Jackson. Mr. A., Mr. Crawford, and Gen. J. therefore remain the strong competitors. Between these three I have certainly a very decided choice. Mr. Crawford's connection with the Radical party, his doubtful principles and disingenuous course in the administration forbid me to desire his elevation. $\mathrm{Mr}$. A. has extraordinary merits. His extensive acquirements, incorruptible morals, and devotion to his country's service furnish him with the strongest and most indisputable claims. But he is, I fear, little fitted for popular government. No man would administer an absolute system better, because he would never prostitute the possession of power to corrupt or tyrannical ends. But I am apprehensive that he will be found to possess very little talent for managing men, which is the most important of all qualities under a government where the people have so immediate a participation, as under ours, in the business of administration. I fear, therefore, should he be elected, that his administration will be disturbed by dangerous and distracting feuds. Swayed by apprehensions like these, . . I am strongly inclined to wish for Gen. Jackson's success. The character of this great man is not at all understood. He has been induced to adopt violent measures for the attainment of useful ends, but I am convinced by what $I$ have seen this winter, that he is a good man, and that he 
was nominated in a frenzy of enthusiasm by a convention at Harrisburg, in Pennsylvania. The regular nominee of the congressional caucus was W. H. Crawford of Georgia. The other candidates were Henry Clay and John Quincy Adams. For the Vice-president there was a general agreement upon Calhoun. There was no opposition between the Northern and the Southern states. Such an issue had been raised for a moment in 1820 , but the Missouri Compromise had settled it so effectually that it was not to be heard of again for several years, and the credit of this had been largely due to Clay. All the four candidates belonged nominally to the Republican party, but in their attitude toward the Constitution Adams and Clay were loose constructionists, while Crawford and Jackson were strict constructionists, and in this difference was foreshadowed a new division of parties. At the election in November, 1824, Mr. Crawford, who stood for the "Virginia dynasty" in a certain sense, received the entire electoral votes of Georgia and Virginia, with 5 votes from New York, 2 from Delaware, and I from Maryland. Mr. Adams had all the New England votes, with 26 from New York, I from Delaware, 3 from Maryland, I from Illinois, 2 from Louisiana. Mr. Clay had the entire vote of Missouri, Kentucky, and Ohio, with 4 from New York. General Jackson received the entire votes of New Jersey, Pennsylvania,

knows how to govern his passions. . . I I is a principal object with the sound politicians of the country to abolish party distinctions and to elevate talent wherever it is found. But as Mr. Adams has been a Federalist, the least inclination towards federal men or federal measures would excite alarm and disturb his popularity. Gen. Jackson. having always been a violent Democrat, might avail himself of the talents of the Federal party without danger, and no one believes that he would be a party man." 
both Carolinas, Tennessee, Alabama, Mississippi, and Indiana, with 7 from Maryland, I from New York, 3 from Louisiana, and 2 from Illinois. All of Crawford's $4 \mathrm{I}$ electoral votes were from the original seaboard states. Of Adams's 84 votes, all but 3 were from the same quarter. Of Clay's 37 , all but 4 were from the West. To Jackson's 99 the West contributed 29, the East 70. If Jackson could have had Clay's Western vote in addition to his own, it would have made I 32, which was one more than the number necessary for a choice. The power of the West was thus distinctly shown for the first time in a national election. As none of the candidates had a majority, it was left for the House of Representatives to choose a President from the three names highest on the list, in accordance with the twelfth amendment to the Constitution. Clay was thus rendered ineligible, and there was naturally some scheming among the friends of the other candidates to secure his powerful coöperation. Clay's feeling toward Adams had for some time been unfriendly, but on the other hand there was no love lost between Jackson and Clay, and the latter was of course sincere in his opinion that Adams was a statesman and Jackson nothing but a soldier. It was not in the least strange, under the circumstances, that Clay should throw his influence in favour of Adams. It would have been strange if he had not done so. The result was that when in the House the vote was taken by states, there were I 3 for Adams, 7 for Jackson, and 4 for Crawford. Adams thus became President, and Jackson's friends, in their bitter disappointment, hungered for a "grievance " upon which they might vent their displeasure, and which might serve as a "rally- 
ing cry" for the next campaign. Benton went so far as to maintain that because Jackson had a greater number of electoral votes than any other candidate, the House was virtually "defying the will of the people" in choosing any name but his. To this it was easily answered that in any case our electoral college, which was one of the most deliberately framed devices of the Constitution, gives but a very indirect and partial expression of the "will of the people"; and furthermore, if Benton's arguments were sound, why should the Constitution have provided for an election by Congress, instead of allowing a simple plurality in the college to decide the election? The extravagance of Benton's objection, coming from so able a source, is an index to the bitter disappointment of Jackson's followers. The needed "grievance" was furnished when Adams selected Clay as his Secretary of State. Many of Jackson's friends interpreted this appointment as the result of a bargain whereby Clay had made Adams President in consideration of obtaining the first place in the cabinet, carrying with it, according to the notion then prevalent, a fair prospect of the succession to the presidency. It was natural enough for the friends of a disappointed candidate to make such a charge. It was to Benton's credit that he always scouted the idea of a corrupt bargain between Adams and Clay. Many people, however, believed it. In Congress, John Randolph's famous allusion to the "coalition between Blifil and Black George - the Puritan and the blackleg - " led to a duel between Randolph and Clay, which served to impress the matter upon the popular mind without enlightening it; the pistol is of small value as an agent of enlightenment. The charge was 
utterly without support and in every way improbable. The excellence of the appointment of Clay was beyond cavil, and the sternly upright Adams was less influenced by what people might think of his actions than any other President since Washington. But in this case he was perhaps too independent. The appointment was no doubt ill-considered. It made it necessary for Clay, in many a public speech, to defend himself against the imputation. To mention the charge to Jackson, whose course in Florida had been censured by Clay, was enough to make him believe it; and he did so to his dying day.

It is not likely that the use made of this "grievance" had any decisive effect in securing victory for Jackson in 1828. Doubtless it helped him, but the causes of his success lay far deeper. The stream of democratic tendency was swelling rapidly. Heretofore our Presidents had been men of aristocratic type, with advantages of wealth or education or social training. In a marked degree all these advantages were united in John Quincy Adams, He was the most learned of all our Presidents. He had been a Harvard professor. He was a trained diplomatist, and had lived much in Europe. He was an able administrative officer. In his character there was real grandeur. For bulldog courage and tenacity he was much like Jackson, but in other respects a stronger contrast than the two men afforded cannot well be imagined. Curiously enough, in point of politeness and grace of manner, the backwoodsman far surpassed the diplomatist. A man with less training in statesmanship than Jackson would have been hard to find. In his defects he represented 
average humanity, while his excellences were such as the most illiterate citizen could appreciate. In such a man the ploughboy and the blacksmith could feel that in some essential respects they had for President one of their own sort. Above all, he was the great military hero of the day, and as such he came to the presidency as naturally as Taylor and Grant in later days, as naturally as his contemporary Wellington, without any training in statesmanship, became prime minister of England. A man far more politic and complaisant than Adams could not have won the election of 1828 against such odds. He obtained 83 electoral votes against 178 for Jackson. Calhoun was reëlected Vice-president. In this election the votes of New York and Maryland were divided almost equally between the two candidates. Jackson got one electoral vote from Maine. All the rest of New England, with New Jersey and Delaware, went for Adams. Jackson carried Pennsylvania, Virginia, both Carolinas, and Georgia, and everything west of the Alleghanies, from the Lakes to the Gulf. There were many Western districts in which Adams did not get a single vote. After this sweeping victory Jackson came to the presidency with a feeling that he had at length succeeded in making good his claim to a violated right, and this feeling had its influence upon his conduct.

In Jackson's cabinet, as first constituted, Martin Van Buren of New York was Secretary of State; S. D. Ingham of Pennsylvania Secretary of the Treasury; J. H. Eaton of Tennessee Secretary of War; John Branch of North Carolina Secretary of the Navy; J. M. Berrien of Georgia Attorney-gen- 
eral; W. T. Barry of Kentucky Postmaster-general. With the exception of Van Buren, as compared with members of earlier cabinets, - not merely with such men as Harnilton, Madison, or Gallatin, but with such as Pickering, Wolcott, Monroe, or even Crawford, - these were obscure names. The innovation in the personal character of the cabinet was even more marked than the innovation in the presidency. The autocratic Jackson employed his secretaries as clerks. His confidential advisers were a few intimate friends who held no important offices. These men - W. B. Lewis, Amos Kendall, Duff Green, and Isaac Hill - came to be known as the "kitchen cabinet." Major Lewis was an old friend who had much to do with bringing Jackson forward for the presidency. The other three were editors of partisan newspapers. Kendall was a man of considerable ability and many good qualities, including a plentiful supply of those virtuous intentions wherewith a certain part of the universe is said to be paved. He was what would now be called a "machine politician." On many occasions he was the ruling spirit of the administration, and the cause of some of its worst mistakes. Jackson's career cannot be fully understood without taking into account the agency of Kendall; yet it is not always easy to assign the character and extent of the influence which he exerted.

A yet more notable innovation was Jackson's treatment of the civil service. This was the great blunder and scandal of his administration, and because we are still suffering from its effects it is in the minds of the present generation more closely associated with Jack- 
son's name than all his good work. The abominable slough of debauchery in which our civil service has wallowed for half a century is not only a disgrace to the American people, but it is probably the most serious of all the dangers that threaten the continuance of American freedom. Its foul but subtle miasma poisons and benumbs the whole body politic. The virus runs through everything, and helps to sustain all manner of abominations, from grasping monopolies and civic jobbery down to political rum-shops. And for a crowning evil, so long as it stays with us, it is next to impossible to get great political questions correctly stated and argued on their merits.

Under all the administrations previous to Jackson's our civil service had been conducted with ability and purity, and might have been compared favourably with that of any other country in the world. The earlier Presidents proceeded upon the theory that public office is a public trust, and cannot, without base dishonour, be treated as a reward for partisan services. They conducted the business of government upon sound business principles, and as long as a postmaster showed himself efficient in distributing the mail, they did not turn him out because of his vote. From the first, however, there were well-meaning people who could not comprehend the wisdom of such a policy. When Jefferson's election brought with it a change of party at the seat of government, there were some who thought it should also bring with it a wholesale change of office-holders. But such was not Jefferson's view of the case. The name of "Jeffersonian Democrat," as applied to a certain class of hungry place-hunters in our time, is an atrocious libel upon that great man. 
Such people would have gone hungry a great while before he would have fed them from the public crib. It was strongly urged upon him once that he should make room in the custom-house for some persons, who, as it was alleged, in helping to elect him President, had virtually saved the country. "Indeed," replied Jefferson, "I have heard that the city of Rome was once saved by geese; but I never heard that these geese were made revenue officers." During the forty years between April 30, I789, and March 4, I829, the total number of removals from office was seventy-four, and out of this number five were defaulters. During the first year of Jackson's administration the number of changes made in the civil service was about two thousand. Such was the sudden and abrupt inauguration upon a national scale of the so-called "spoils system." The phrase originated with W. L. Marcy, of New York, who in a speech in the Senate in 1831 declared that "to the victors belong the spoils." The man who said this of course did not realize that he was making one of the most infamous remarks recorded in history. There was, however, much aptness in his phrase, inasmuch as it was a confession that the business of American politics was about to be conducted upon principles fit only for the warfare of barbarians. The senator from New York had been reared in a poisonous atmosphere. The "spoils system" was first gradually brought to perfection in the state politics of New York and Pennsylvania, and it was inevitable that it should sooner or later be introduced into the sphere of national politics. There can hardly be a doubt that if Jackson had never been President, similar results would have followed at about the same time. If Adams had been reëlected, the 
catastrophe would have been deferred for four years, but it was bound to come soon. This in no wise alters or qualifies Jackson's responsibility for the mischief, but it helps us to comprehend it in its true relations. At that time the notion had firmly planted itself in men's minds that there is something especially democratic, and therefore meritorious, about "rotation in office." It was argued, with that looseness of analogy so common in men's reasonings about history and politics, that permanency of tenure tends to create an "aristocracy of office," and is therefore contrary to the "spirit of American institutions." It was, as I said before, an age of crude, unintelligent experiments in democracy; and as soon as this notion had once got into men's heads, it was inevitable that the experiment of the "spoils system " must be tried, just as the experiment of an elective judiciary had to be tried. The way was prepared in 1820 by Crawford, when he succeeded in getting the law enacted that limits the tenure of office to four years. This dangerous measure excited very little discussion at the time. People could not understand the evil until taught by hard experience. The honest Jackson would have been astonished if he had been told that he was laying the foundations of a gigantic system of corruption. He was very ready to believe ill of political opponents, and to make generalizations from extremely inadequate data. Democratic newspapers, while the campaign frenzy was on them, were full of windy declamation about the wholesale corruption introduced into all parts of the government by Adams and Clay. In point of fact there has never been a cleaner administration in all our history than that of Quincy Adams, 
but nothing was too bad for Jackson to believe of these two men. It was quite like him to take all the campaign lies about them as literally true; and when Tobias Watkins, the fourth auditor of the treasury, was found to be delinquent in his accounts, it was easy to suppose that many others were, in one way or another, just as bad. In his wholesale removals, Jackson doubtless supposed he was doing the country a service by "turning the rascals out." The immediate consequence of this demoralizing policy was a struggle for control of the patronage between Calhoun and Van Buren, who were rival aspirants for the succession to the presidency.

A curious affair now came in to influence Jackson's personal relations to these men. Early in I 829, John Eaton, Secretary of War, married a Mrs. Timberlake, with whose reputation gossip had been busy. It would seem that this ill repute was deserved, but Jackson was always slow to believe charges against a woman. His own wife, who had been outrageously maligned by the Whig newspapers during the campaign, had lately died. My venerable friend, Colonel Edward Butler, of St. Louis, the oldest living graduate of West Point, was Jackson's ward, and more familiar with his private life for forty years than any other man. He cherishes Jackson's memory with a feeling akin to idolatry, and I only wish I could begin to remember all the interesting things he has told me about him. They tried to keep newspaper lies from coming to Mrs. Jackson's ears, but of course in vain. Many a time Colonel Butler, coming suddenly into the room, would find the poor old lady sitting absorbed in grief, with her great quarto Bible in her lap and tears stealing down her 
cheeks. She was one of the best women that ever lived, says Colonel Butler, and there can be little doubt that she died of a broken heart. Whig editors had killed her as much as if they had taken guns and shot her. Soon after her death Mrs. Eaton came one day to the President, and throwing herself at his feet, told him with many sobs and tears how she was ill used and persecuted. Could nothing be done, she implored, to mend matters? Jackson was haggard with grief, and fiercely vindictive. He knew that his wife had been wickedly slandered; he took it for granted that the case must be the same with Mrs. Eaton. In this he was doubtless mistaken, but his letters on the subject are written in a noble temper and fully reveal the spirit which made him take Mrs. Eaton's part with more than his customary vehemence. Mrs. Calhoun and the wives of the secretaries would not recognize Mrs. Eaton. Mrs. Donelson, wife of the President's nephew, and now mistress of ceremonies at the White House, took a similar stand. Jackson scolded his secretaries and sent Mrs. Donelson home to Tennessee, but all in vain. He found that vanquishing Wellington's veterans was a light task compared with that of contending against the ladies in an affair of this sort. Foremost among those who frowned Mrs. Eaton out of society was Mrs. Calhoun. On the other hand, Van Buren, a widower, found himself able to be somewhat more complaisant, and accordingly rose in Jackson's esteem. The fires were fanned by Lewis and Kendall, who saw in Van Buren a more eligible ally than Calhoun. Presently intelligence was obtained from Crawford, who hated Calhoun, to the effect that the latter, as member of Monroe's cabinet, had disap- 
proved of Jackson's conduct in Florida. This was quite true, but Calhoun had discreetly yielded his judgment to that of the cabinet, led by Adams, and thus had officially sanctioned Jackson's conduct. These facts, as handled by Eaton and Lewis, led Jackson to suspect Calhoun of treacherous double-dealing, and the result was a quarrel which broke up the cabinet. In order to get Calhoun's friends, Ingham, Branch, and Berrien, out of the cabinet, the other secretaries began by resigning. This device did not succeed, and the ousting of the three secretaries entailed further quarrelling, in the course of which the Eaton affair and the Florida business were beaten threadbare in the newspapers and evoked sundry challenges to deadly combat. ${ }^{1}$ In the spring and

\section{${ }^{1}$ Mrs. Lee to Colonel Gantt}

[Apropos of General Jackson's relations with Mrs. Eaton and Mr. Calhoun. The original letter from which these extracts are taken is dated Silver Spring, May 23, 1889, and is preserved among Dr. Fiske's papers.]

“. . . I shall relate chiefly what I heard when General Jackson visited my Parents or when his guest. I was eleven years old when I first met him, and twenty-three at our last parting. When my Parents removed from Kentucky to Washington my brothers did not accompany us, consequently I was more than ever their constant companion, being their only daughter, and Mother my teacher. . . . The first time I ever heard Mrs. Eaton's name mentioned was in a conversation between Mother and the President, where he spoke of the annoyance given him by Mrs. Donelson's refusal to be civil to Mrs. Eaton when she called at the White House; he thought Mrs. Eaton, as the wife of his friend and a member of the Cabinet, ought to be politely received, but 'Emily' is influenced by her husband who is under 'Calhoun's thraldom.' This was the purport of his complaint, and out of this domestic disagreement arose the gossip which was well known to have been kept up by Mrs. Eaton, who enjoyed notoriety even at the expense of her own reputation and of the truth.... Soon after Major and Mrs. Donelson went to Tennessee for a short time. I afterwards heard from my Parents that they repented of their position, and Mrs. 


\section{summer of 1831 , the new cabinet was formed, consist- ing of Edward Livingston, Secretary of State; Louis}

Eaton was received as a visitor, but to my positive conviction never to stay even for a day. . . . Nothing strikes me more in reviewing the past than the liberties taken with the General by those who formed his family circle, and the gentleness with which he submitted to impositions, especially of servants and children. But if it touched a point of duty he was firm, though always amiable and kind... I was frequently at the White House in childhood and as a young lady. . . . I never met Mrs. Eaton there. When she went she did so as any other acquaintance, and from what I have heard was received with but scant courtesy by Mrs. Donelson. .. The White House has never since been graced with a more beautiful, refined, gentle woman [Mrs. D.]. - except perhaps she may have been excelled by Mrs. Cleveland, who had greater modern educational advantages and the rare gift of tact. . . I I heard General Jackson comment but once on Mrs. Eaton . . . during my visit to the Hermitage in 1842. . .

"Mrs. Eaton's daughter, Virginia Timberlake, was my school-mate at Mme. Sigoigne's; she was a brilliant woman in mind, appearance, and accomplishments, who in spite of her want of veracity attracted me very much, but my mother forbade any intimacy as she did not approve of Miss Timberlake or visit Mrs. Eaton. But Virginia was so amusing that I fear I would have been very disobedient but for my dear friend and monitor, Isabella Cass, who had the same instructions from home, for I know that neither the Cass nor the Woodbury families, with whom I have had a lifelong intimacy, visited Mrs. Eaton, though Judge Woodbury and Governor Cass were members of the Jackson Cabinet. After we left school, by hard begging, I.sometimes got permission to go tơ see Virginia, which calls she never returned. Still when in trouble she would write for me to come to her. At that time, she was engaged to be married to Barton Key, to which both families objected bitterly. Mrs. Eaton's treatment of her daughter amounted to cruelty. Virginia escaped from some of it by deceiving her mother. I told the General of this episode. . . . He had always felt sorry for 'The Timberlake children,' knowing that their 'Mother's lack of truth would be fatal to them.' He had known their grandparents, the O'Neils, when he was Senator from Tennessee and Mrs. O'Neil had been very kind to his wife, Mrs. Jackson, when ill; and General Jackson, when consulted by his 'friend Eaton' about his marriage, advised him to marry 'the Widow Timberlake' and promised to stand by him. ... I am convinced, and with much reason, that Mme. Sampayo, alias Virginia Timberlake, has inspired these French romances about her mother and General Jackson : she disliked and spoke bitterly of both. and several times in the past thirty years, I have seen and heard of ... different articles on this subject in Paris paper. She always changes her history and gets coarser as she grows 


\section{McLane, Treasury ; Lewis Cass, War; Levi Woodbury, Navy; R. B. Taney, Attorney-general; in post-office,}

older. I suppose she may need money, or craves notoriety which it may bring her. ... .

"When my Parents bought their home opposite the War Department it needed extensive repairs, and we went to live there before it was free from the smell of paint. The President when he called insisted that I stay at the White House (as the paint made me ill) until the odour was gone. I went, and it was quite six weeks before he and I thought it safe for me to return home. I never had a happier visit. He did smoke his pipe after dinner, and I have filled his fresh, clean clay pipes, with long cane stems, many times for him; but he rarely used a pipe more than one day, and there was a bundle of canes brought along with the new pipes.... I thus became informed about some very important matters. The removal of the Government funds from the Bank of the United States which was then in progress was one of them. The President sent several friends to New York to obtain reliable information from commercial monied men about banks or institutions to which it might be safe to transfer the Government Deposits. Mr. Kendall, from his letter, must have been one of them, and wrote in the most discouraging tone, to which the President replied; and I either copied his letter or he dictated it, for I remember distinctly that he warned Mr. Kendall not to be misled by the emissaries of Nicholas Biddle ('who is now a desperate man') and 'who is nagging the footsteps of every prominent official,' because nothing but the Public Deposit concealed the fact that Biddle's Bank was at that moment 'bankrupt.' That was the year your class graduated at West Point. . . .

"Blair mentioned to me that Mr. Fiske does not believe that General Jackson threatened to hang Mr. Calhoun. I think he is mistaken. . . . I am certain that the main import of the story was (as I heard it) true, which was, upon the first 'overt act' at Charleston, he would have Mr. Calhoun and the other leading Conspirators arrested and tried for treason, of which they would undoubtedly be found guilty, when he would hang every one of them. I heard Mr. Crittenden and Father talk about this matter; both laughed very heartily at the way in which Governor Letcher described the effect on Mr. Calhoun of this threat, when Governor Letcher reported to him the conversation with General Jackson in which the threat was made, Governor Letcher saying to Mr. Calhoun that he came directly from the White House to inform him of his peril. In 1842 , when at the Hermitage, General Jackson expressed his opinion to me very freely of $\mathrm{Mr}$. Calhoun, whose intellect he said was of the highest order, but he knew him to be heartless, selfish, and a physical coward. Mr. Clay was his personal enemy and had done him wrongs $\mathrm{Mr}$. Calhoun dared not do, but Mr. Clay was a brave man, and a patriot, who loved, and would have gladly given his life to serve his country." 
no change. On Van Buren's resignation, Jackson at once appointed him minister to England, but there was a warm dispute in the Senate over his confirmation, and it was defeated at length by the casting vote of Calhoun. This check only strengthened Jackson's determination to have Van Buren for his successor in the presidency. The progress of this quarrel entailed a break in the "kitchen cabinet," in which Duff Green, editor of the Telegraph and friend of Calhoun, was thrown out. His place was taken by Francis Preston Blair of Kentucky, a man of eminent ability and earnest patriotism. To him and his sons, as energetic opponents of nullification and secession, our country owes a debt of gratitude which can hardly be overstated. Blair's indignant attitude toward nullification brought him at once into earnest sympathy with Jackson. In December, I830, Blair began publishing the Globe, the organ henceforth of Jackson's party. For a period of ten years, until the defeat of the Democrats in 1840 , Blair and Kendall were the ruling spirits in the administration. Their policy was to reëlect Jackson to the presidency in $183_{2}$, and make Van Buren his successor in 1836 .

During Jackson's administration there came about a new division of parties. The strict constructionists, opposing internal improvements, protective tariff, and national bank, retained the name of Democrats, which had long been applied to members of the old Republican party. The term Republican fell into disuse. The loose constructionists, under the lead of Clay, took the name of Whigs, as it suited their purposes to describe Jackson as a kind of tyrant; and they tried to dis- 
credit their antagonists by calling them Tories, but the device found little favour. On strict constructionist grounds Jackson in 1829 vetoed the bill for a government subscription to the stock of the Maysville turnpike in Kentucky; and two other similar bills he disposed of by a new method which the Whigs indignantly dubbed a "pocket veto." The struggle over the tariff was especially important as bringing out a clear expression of the doctrine of nullification on the part of South Carolina. Practically, however, nullification was first attempted by Georgia in the case of the disputes with the Cherokee Indians. Under treaties with the federal government these Indians occupied lands which were coveted by the white people. Adams had made himself very unpopúlar in Georgia by resolutely defending the treaty rights of these Indians. Immediately upon Jackson's election the state government assumed jurisdiction over their lands, and proceeded to legislate for them, passing laws that discriminated against them. Disputes at once arose, in the course of which Georgia twice refused to obey the Supreme Court of the United States. At the request of the governor of Georgia, Jackson withdrew the federal troops from the Cherokee country and refused to enforce the rights which had been guaranteed to the Indians by the United States. His feelings toward Indians were those of a frontier fighter, and he asked, with telling force, whether an Eastern state, such as New York, would endure the nuisance of an independent Indian state within her own boundaries. In his sympathy with the people of Georgia on the particular question at issue, he seemed for the moment to be conniving at the dangerous prin- 
ciple of nullification. These events were carefully noted by the politicians of South Carolina. The protectionist policy which since the peace of 18 I $_{5}$ had been growing in favour at the North had culminated in 1828 in the so-called "tariff of abominations." This tariff, the result of a wild, helter-skelter scramble of rival interests, deserved its name on many accounts. It discriminated, with especial unfairness, against the Southern people, who were very naturally and properly enraged by it. A new tariff, passed in 1832, modified some of the most objectionable features of the old one, but still failed of justice to the Southerners. Jackson was opposed to the principle of protective tariffs, and from his course with Georgia it might be argued that he would not interfere with extreme measures on the part of the South. During the whole of Jackson's first term there was more or less vague talk about nullification. The subject had a way of obtruding itself upon all sorts of discussions, as in the famous debates on Foote's resolutions which lasted over five months in 1830 and called forth Webster's wonderful speech in reply to Hayne. A few weeks after this speech, at a public dinner in commemoration of Jefferson's birthday, after sundry regular toasts had seemed to indicate a drift of sentiment in approval of nullification, Jackson suddenly arose with a volunteer toast, "Our Federal Union: it must be preserved." It was like a bombshell. Calhoun was prompt to reply with a toast and speech in behalf of "Liberty, dearer than the Union," but the nullifiers were bitterly disappointed and chagrined. In spite of this warning, South Carolina held a convention November I9, 1832 , and declared the tariffs of 1828 and 1832 to be null and void in South Caro- 
lina; all state officers and jurors were required to take an oath of obedience to this edict; appeals to the federal Supreme Court were prohibited under penalties; and the federal government was warned that an attempt on its part to enforce the revenue laws would immediately provoke South Carolina to secede from the Union. The ordinance of nullification was to take effect on the Ist of February, 1833, and preparations for war were begun at once. On the I6th December the President issued a proclamation in which he declared that he should enforce the laws in spite of any and all resistance that might be made; and he showed that he was in earnest by forthwith sending Lieutenant David Farragut with a naval force to Charleston harbour and ordering General Scott to have troops ready to enter South Carolina if necessary. In the proclamation, which was written by Livingston, the President thus defined his position: ${ }^{1}$ "I consider the power to annul a law of the United States, assumed by one state, incompatible with the existence of the Union, contradicted expressly by the letter of the Constitution, unauthorized by its spirit, inconsistent with every principle on which it was founded, and destructive of the great object for which it was formed." Governor Hayne of South Carolina issued a counter-proclamation, and a few days afterward Calhoun resigned the vice-presidency and was chosen to succeed Hayne in the senate. Jackson's resolute attitude was approved

${ }^{1}$ Mrs. Elizabeth B. Lee in her letter to Colonel Gantt, quoted on pages 292-294, wrote, " My Father said to me that the Nullification Proclamation as first drafted by General Jackson was a far more able paper than the polished substitute based on it and written by Mr. Livingston and adopted by the President." 
by public opinion throughout the country. By the Southern people generally the action of South Carolina was regarded as precipitate and unconstitutional. Even in that state a Union convention met at Columbia and announced its intention of supporting the President. In January Calhoun declared in the Senate that his state was not hostile to the Union and had not meditated an armed resistance; a "peaceable secession," to be accomplished by threats, was probably the ultimatum really contemplated. In spite of Jackson's warning, the nullifiers were surprised by his unflinching attitude, and complained of it as inconsistent with his treatment of Georgia. When the first of February came the nullifiers deferred action. In the course of that month a bill for enforcing the tariff passed both houses of Congress, and at the same time Clay's compromise tariff was adopted, providing for the gradual reduction of the duties until $\mathrm{I} 84_{2}$, after which all duties were to be kept at twenty per cent. This compromise was well-meant but pernicious, for it enabled the nullifiers to claim a victory and retreat from their position with colours flying. Calhoun, indeed, afterward pointed to the issue of the contest as conclusively proving the beneficent character of his theory of nullification. Here, he said, by merely threatening to nullify an obnoxious, and as he maintained unconstitutional, act of federal legislation, South Carolina had secured its repeal, and all was pleasant and peaceful! It was not Jackson, however, but Clay, that Calhoun had to thank for the compromise, nor were the nullifiers by any means as well satisfied as he tried to believe.

The nullifiers, indeed, had made a great mistake 
when they inferred from Jackson's attitude toward Georgia that they could count upon his aid or connivance in the case of South Carolina. The insubordination of Georgia was shown in refusing to obey a decree of the Supreme Court, and Jackson had no fondness for the Supreme Court. He is said to have exclaimed, somewhat maliciously, "John Marshall has made his decision; now let him enforce it!" But the nullification act of South Carolina was a direct challenge to the executive head of the United States government. He could see its bearings in an instant, and it aroused all the combativeness that was in his nature.

During this nullification controversy Jackson kept up the attacks upon the United States Bank which he had begun in his first annual message to Congress in 1829. His antipathy to such a bank, in which the federal government was a shareholder and virtually to some extent a director, had been shown as long ago as Washington's administration, when the bank was first established. For two reasons it was especially obnoxious to the people of the South and the Southwest, and to the Democratic party generally. In the first place, the question as to the constitutional authority of Congress to establish such an institution was preëminently the test question between strict constructionists and loose constructionists. In the great fight between them it played the same part that Little Round Top played in the battle of Gettysburg. Once let the enemy carry that point and the whole field was lost. The contest over the assumption of state debts had faded out of sight before Jackson's presidency; it had become what the Germans call an "ïberwundene 
standpunkt." The contest over protective tariffs, on the other hand, had only lately become severe. But there the bank had been standing for nearly forty years, a perpetual menace to the theory of strict construction. President Madison had reluctantly signed the bill for its recharter in 1816 , apparently because he could think of no practical alternative. The new charter was to expire in 1836 , and President Jackson, in his determination that it should not again be renewed, was restrained by no such practical considerations.

In the second place, the bank was hated as the most prominent visible symbol of Hamilton's plan for an alliance between the federal government and the moneyed classes of society. In this feeling there was no doubt something of the sheer prejudice which ignorant people are apt to entertain against capitalists and corporations. But the feeling was in the main wholesome. There was really very good reason for fearing that a great financial institution, so intimately related to the government, might be made a most formidable engine of political corruption. The final result of the struggle, in Tyler's presidency, showed that Jackson was supported by the sound common sense of the American people.

Jackson's suggestions with reference to the bank in his first message met with little favour, especially as he coupled them with suggestions for the distribution of the surplus revenue among the states. He returned to the attack in his two following messages, until, in $183^{2}$, the bank felt obliged in self-defence to apply, somewhat prematurely, for a renewal of its charter on the expiration of its term. Charges brought against 
the bank by Democratic representatives were investigated by a committee, which returned a majority report in favour of the bank. A minority report sustained the charges. After prolonged discussion the bill to renew the charter passed both houses and July Io, I 832, was vetoed by the President. An attempt to pass the bill over the veto failed of the requisite twothirds majority.

Circumstances had already given a flavour of personal contest to Jackson's assaults upon the bank. There was no man whom he hated so fiercely as .Clay, who was at the same time his chief political rival. Clay made the mistake of forcing the bank question into the foreground, in the belief that it was an issue upon which he was likely to win in the coming presidential campaign. . Clay's movement was an invitation to the people to defeat Jackson in order to save the bank; and this naturally aroused all the combativeness in Jackson's nature. His determined stand impressed upon the popular imagination the picture of a dauntless "tribune of the people " fighting against the "monster monopoly." Clay unwisely attacked the veto power of the President, and thus gave Benton an opportunity to defend it by analogies drawn from the veto power of the ancient Roman tribune, which in point of fact it does not at all resemble. The discussion helped Jackson more than Clay. It was also a mistake on the part of the Whig leader to risk the permanence of such an institution as the United States Bank upon the fortunes of a presidential campaign. It dragged the bank into politics in spite of itself, and by thus affording justification for the fears to which Jackson had appealed, played directly into 
his hands. In this campaign all the candidates were for the first time nominated in national conventions. There were three conventions, all held at Baltimore. In September, I831, the anti-masons nominated William Wirt of Virginia, in the hope of getting the National Republicans or Whigs to unite with them, but the latter, in December, nominated Clay. In the following March the Democrats nominated Jackson, with Van Buren for Vice-president. During the year $1_{32}$ the action of Congress and President, with regard to the bank charter, was virtually a part of the campaign. In the election South Carolina voted for candidates of her own, John Floyd of Virginia and Henry Lee of Massachusetts. There were 219 electoral votes for Jackson, 49 for Clay, I I for Floyd, and 7 for Wirt. Besides his own state, Clay carried Maryland and Delaware, Connecticut, Rhode Island, and Massachusetts. All the rest of the country, including half of New England, went for Jackson. He interpreted this overwhelming victory as a popular condemnation of the bank and approval of all his actions as President. The enthusiastic applause from all quarters which now greeted his rebuke of the nullifiers served still further to strengthen his belief in himself as a "saviour of society" and champion of "the people." Men were getting into a state of mind in which questions of public policy were no longer argued upon their merits, but all discussion was drowned in cheers for Jackson. Such a state of things was not calculated to check his natural vehemence and disposition to override all obstacles in carrying his point. He now felt it to be his sacred duty to demolish the bank. In his next message to 
Congress he created some alarm by expressing doubts as to the bank's solvency, and recommending an investigation to see if the deposits of public money were safe. In some parts of the country there were indications of a run upon the branches of the bank. The Committee on Ways and Means investigated the matter and reported the bank as safe and sound, but a minority report threw doubt upon these conclusions, so that the public uneasiness was not allayed. The conclusions of the members of the committee, indeed, bore little reference to the evidence before them, and were determined purely by political partisanship. Jackson made up his mind that the deposits must be removed from the bank. The act of 1816 , which created that institution, provided that the public funds might be removed from it by order of the Secretary of the Treasury, who must, however, inform Congress of his reasons for the removal. As Congress resolved, by heavy majorities, that the deposits were safe in the bank, the spring of 1833 was hardly a time when a Secretary of the Treasury would feel himself warranted, in accordance with the provisions of the act, to order their removal. Secretary McLane was accordingly unwilling to issue such an order. In what followed, Jackson had the zealous coöperation of Kendall and Blair. In May McLane was transferred to the State Department, and was succeeded in the treasury by W. J. Duane of Pennsylvania. The new secretary, however, was convinced that the removal was neither necessary nor wise, and in spite of the President's utmost efforts refused either to issue the order or to resign his office. In September, accordingly, Duane was removed and R. B. Taney of Maryland appointed 
in his place. Taney at once ordered that after the Ist of October the public revenues should no longer be deposited with the national bank, but with sundry state banks, which soon came to be known as the "pet banks." Jackson alleged, as one chief reason for this proceeding, that if the bank were to continue to receive public revenues on deposit, it would unscrupulously use them in buying up all the members of Congress, and thus securing an indefinite renewal of its charter. This, he thought, would be a death-blow to free government in America. His action caused intense excitement and some commercial distress, and prepared the way for further disturbance. In the next session of the Senate Clay introduced a resolution of censure, which was carried after a debate which lasted all winter. It contained a declaration that the President had assumed "authority and power not conferred by the Constitution and laws, but in derogation of both." Jackson protested against the resolution, but the Senate refused to receive his protest. Many of his appointments were rejected by the Senate, especially those of the directors of the bank and of Taney as Secretary of the Treasury. An attempt was made to curtail the President's appointing power. On the other hand, many of the President's friends declaimed against the Senate as an aristocratic institution which ought to be abolished. Benton was Jackson's most powerful and steadfast ally in the Senate. Benton was determined that the resolution of censure should be expunged from the records of that body, and his motion continued to be the subject of acrimonious debate for two years. The contest was carried into the state elections, and some senators 
resigned in consequence of instructions received from their state legislatures. At length, January I6, I837, a few weeks before Jackson's retirement from office, Benton's persistency triumphed and the resolution of censure was expunged. It has been customary with Whig writers to laugh at Benton for this, and to call his conduct spiteful, boyish, and silly. It would be more instructive, however, to observe that his conduct was the natural outgrowth of the extreme theory of popular government which he held. He looked upon Jackson as a disinterested tribune of the people, who for carrying out the popular will and ridding the country of an exceedingly dangerous institution, at the cost of some slight disregard of red tape, had incurred unmerited censure; and it seemed to him an important matter, and not a mere idle punctilio, that such a wrongful verdict should be reversed. There was a good deal of truth, as well as some error, in this view. If pushed to extremes it would result in unbridled democracy, which in the hands of a powerful and unscrupulous leader is liable to pass into Cæsarism. Webster and the Whigs, in opposing this extreme view of popular government, in contending for the necessity of constitutional checks in such a country as ours, and in blaming Jackson for his autocratic manner of overriding such checks, were quite right. At the same time there can be little doubt that Jackson was purely disinterested, and that in this particular case he did fully represent the will of the people in overthrowing a dangerous institution. The commercial panic which followed in 1837 was by most people attributed to his removal of the deposits. I shall endeavour to show, in my next lecture, on " Tip- 
pecanoe and Tyler too," that this notion was entirely incorrect, and the causes of the great panic lay much deeper than was supposed at the time. The belief that it was due to Jackson's policy was a chief cause of the Whig victory in 1840 ; but as soon as the immediate effects of the panic were over, there was a general acquiescence in the final death-blow dealt to the bank by President Tyler, and since then nobody has had the hardihood to ask that it should be restored.

In foreign affairs Jackson's administration won great credit through its enforcement of the French spoliation claims. European nations which had claims for damages against France, on account of spoliations committed by French cruisers during the Napoleonic wars, had found no difficulty after the peace of I 8 I5 in obtaining payment; but the claims of the United States had been superciliously neglected. In I83I, after much fruitless negotiation, a treaty was made by which France agreed to pay the United States five million dollars in six annual instalments. The first payment was due Febuary 2, 1833. A draft for the amount was presented to the French minister of finance, and payment was refused on the ground that no appropriation for that purpose had been made by the Chambers. Louis Philippe brought the matter before the Chambers, but no appropriation was made. Jackson was not the man to be trifled with in this way. In his message of December, I834, he gravely recommended to Congress that a law be passed authorizing the capture of French vessels enough to make up the amount due. The French government was enraged, and threatened war unless the President should apologize, - not a hopeful sort of demand to make of Andrew 
Jackson. Here Great Britain interposed with good advice to France, which led to the payment of the claim without further delay. The effect of Jackson's attitude was not lost upon European governments, while at home the hurrahs for "Old Hickory" were louder than ever. The days when foreign powers could safely insult us were evidently gone by.

In the election of $18{ }_{3} 6$ Jackson's wishes were fulfilled in the victory of Van Buren, with I 70 electoral votes against $\mathrm{I} 24$ for all other candidates. The remainder of Jackson's life was spent in his Tennessee home, known as the Hermitage. About the time of his election to the presidency the ugly wound received in the duel with Dickinson in I 806, which had never properly healed, broke out afresh and became more and more troublesome, until his most intimate friends were inclined to attribute to it his death, which occurred on the $3 \mathrm{~d}$ of June, 1845 . Throughout his extraordinary career he had been devoutly religious, and one cannot fully comprehend him without taking into account the element of the Puritan person that was so strong in him. There probably never lived a man more strictly conscientious, according to his own somewhat narrow lights, than Andrew Jackson. Whether he ever felt moved to forgive his enemies may be doubted, for it never occurred to him that he was not in the right. A contrite spirit he can hardly have had, but after all his warfare he sank peacefully to rest. His remarkable influence over the common people had not ceased with his presidency, and it survived his death until it ended in a kind of Barbarossa legend quite rare among such a people as ours. To this day, we are told, there is some happy valley in western Pennsylvania, the precise 
locality of which is not too strictly indicated, where old men every fourth year, in the month of November, still hobble to the polls and drop into the ballot-box their loyal vote for Andrew Jackson!

The period of Jackson's presidency was one of the most remarkable in the history of the world, and nowhere more remarkable than in the United States. It was signalized by the introduction and rapid development of railroads, of ocean navigation, of agricultural machines, anthracite coal, and friction matches, of the modern type of daily newspaper, of the beginnings of such cities as Chicago, of the steady immigration from Europe, of the rise of the Abolitionists and other reformers, and of the blooming of American literature, when, to the names of Bryant, Cooper, and Irving, were added those of Longfellow, Whittier, Prescott, Holmes, and Hawthorne. The rapid expansion of the country, and the extensive changes in ideas and modes of living, brought to the surface much crudeness of thought and action. As the typical popular hero of such a period, Andrew Jackson must always remain one of the most picturesque and interesting figures in American history. The crudeness of some of his methods, and the evils that have followed from some of his measures, are obvious enough, and have often been remarked upon. But when it is said that he was utterly ignorant of the true principles of statesmanship, and conducted himself in his presidency like a bull in a china shop; when it is urged that his election to the presidency was a thing to be lamented, and that we ought never to have had any kind of man for chief magistrate except the kind represented by our first six Presidents, 
- one can hardly yield unqualified assent to such propositions. It is a source of legitimate pride that we live in a country where a man may rise from the humblest origins to the most exalted position in which his fellow-countrymen can place him. If it be true that mere chance may bring about such a rise of fortune, it is at least very seldom that such can be the case. Usually it must require such rare qualities of mind and character, such richness of experience and such knowledge of men, as to be more than equivalent to a great deal that is conventionally classed as training and scholarship. No man in his senses will for a moment imagine that the scholarly Sumner could ever have performed the herculean task allotted to Abraham Lincoln. Now in the case of Andrew Jackson, while he was not versed in the history and philosophy of government, it is far from correct to say that there was nothing of the statesman about him. On the contrary, it may be maintained that in nearly all his most important public acts, except those that dealt with the civil service, Jackson was right. His theory of the situation was not reached by scientific methods, but it was sound, and it was much needed. Among the ablest books on government that have ever been written - books that ought to be carefully read and deeply pondered by every intelligent American man and woman - are the three works of Herbert Spencer, entitled "Social Statics," "The Study of Sociology," and "Man and the State." The theory of government set forth in these books is that of the most clearheaded and powerful thinker now living in the world, a man who, moreover, is thinking the thoughts of to-morrow as well as of to-day. In spirit it is most 
profoundly American, but not in the sense in which that word was understood by Clay and the Whigs. It was Jackson whose sounder instincts prompted him to a course of action quite in harmony with the highest political philosophy. During the administration of John Quincy Adams there was fast growing up a tendency toward the mollycoddling, old granny theory of government, according to which the ruling powers are to take care of the people, build their roads for them, do their banking for them, rob Peter to pay Paul for carrying on a losing business, and tinker and bemuddle things generally. It was, of course, beyond the power of any man to override a tendency of this sort, but Jackson did much to check it; and still more would have come from his initiative if the questions of slavery and secession had not so soon come up to absorb men's minds and divert attention from everything else. The protective theory of government has too much life in it yet; but without Jackson it would no doubt have been worse. His destruction of the bank was brought about in a way that one cannot wish to see often repeated; but there can be little doubt that it has saved us from a great deal of trouble and danger. By this time the bank, if it had lasted, would probably have become a most formidable engine of corruption.

Herein Jackson was powerfully prompted and aided by Van Buren, who stood in somewhat the same relation to him as Hamilton to Washington. Unquestionably Van Buren had a more philosophical and luminous view of the proper sphere and functions of government, in its relations to the people, than any other American statesman since Jefferson. The mantle 
of Jefferson fell upon Van Buren, and it was to Jackson's credit that he took that statesman into his innermost counsels. The soldier-President, though doubtless at first actuated by personal motives, soon found the soundest kind of support.

But it is upon his attitude toward the nullifiers that Jackson's most conspicuous claim to our gratitude is based. The question as to whether the federal Constitution created a nation or not was never really settled until it was settled by war. Previous to Jackson's presidency, people's ideas on the subject were very hazy, and when single states, or sections of the country, grumbled and threatened, nobody knew exactly what ought to be done about it. It was significant that Webster's great speech and Jackson's decisive action should have come so near together. Webster's speech was not only a most masterly summing up of the situation, but for sublime eloquence we must go back to the time of Demosthenes to find its equal. Among the forces that have held the Union together, the intelligent response of the popular mind to that speech, and the strong emotions it awakened, must be assigned a very high place. But, after all, it was only Mr. Webster's speech; it did not create a precedent for action; it was something which a federal executive might see fit to follow, or might not. But from the moment when President Jackson said in substance to the nullifiers, "Gentlemen, if you attempt to put your scheme into practice, I shall consider it an act of war and shall treat it accordingly," from that moment there was no mistaking the significance of the action. It created a precedent which, in the hour of supreme danger, even the puzzled, reluctant, hesitating Buchanan could not 
AND AMERICAN DEMOCRACY SEVENTY YEARS AGO 3 I 3 venture to disregard. The recollection of it had much to do with setting men's faces in the right direction in the early days of I86I; and those who lived through that doubting, anxious time will remember how people's thoughts went back to the grim, gaunt figure, long since at peace in the grave, and from many and many a mouth was heard the prayer, $\mathrm{O}$ for one hour of Andrew Jackson! 



\section{VIII}

\section{HARRISON, TYLER}

AND THE WHIG COALITION 



\section{VIII \\ HARRISON, TYLER \\ AND THE WHIG COALITION}

IT would be hard to find in the whole field of history a subject more interesting in its details or more richly suggestive in its illustrations of broad philosophical principles than the development of political parties in the United States since the adoption of our federal Constitution. It is the story of the rapid expansion of principles and methods of government long practised on a small scale in the townships of New England and the parishes and counties of the Southern states, until they have become adapted to the management of an imperial dominion extending from ocean to ocean. Population has grown with unexampled rapidity, the arts and sciences have achieved such conquests as our grandfathers would have deemed incredible, the growing complexity of modern industry has quite changed the aspect of society, commercial problems have taken on dimensions difficult to grasp, strangers from all parts of the earth come thronging in to share our advantages, while too often they need to be taught the very rudiments of our political methods, vast tracts of wilderness have been subdued, rude villages springing up on distant prairies change as by magic into noble cities, new states endowed with ample liberty of self-government are added to our federal commonwealth, till the constellation is about 
to number more than forty stars; yet amid all this huge development of human activity the political structure reared a century ago has increased in elastic strength. In spite of all shortcomings, it has shown itself in grave emergencies equal to the situation, and it has fulfilled with supreme efficiency the first duty of government, the duty of preserving order and inspiring confidence. While it has once been called upon to deal with a convulsion as formidable as ever threatened the existence of a nation, its success in overcoming the evil has been such as to convince us more than ever of its invincible strength; and our trust in it reaches sublimity when shown in the profound quiet which attends upon a presidential election in which eleven million votes are cast and the administration of affairs passes from one party to another. People in the Old World often allude to American things as if bigness were their only noticeable attribute. But in the physical dimensions of the facts here cited there is deep moral significance. They furnish unimpeachable testimony to the essential soundness of American political life, and justify us in looking forward with hope to the future. Without for a moment underrating the perils that beset us, or the serious obstacles to right living that are yet to be overcome, we feel that the success already achieved is such that we may confront these dangers and hindrances with cheerful courage.

If the partisan view of American politics were correct, no such sound development of national life would have been possible in this country. According to the partisan theory, which we may find daily expounded in the newspapers and which makes every fourth year the occasion for so much vapid rhetoric and so many 
shameless lies, - according to this theory, all the political intelligence, all the public virtue, all the patriotism, in the United States are confined to one-half of the people, while the other half are not only unintelligent and unscrupulous, but actuated by an unaccountable preference for foreign over American interests. According to this theory American party strife is a phase of the everlasting struggle between Ormuzd and Ahriman, and all means, fair or foul, must be called into requisition in order to suppress the evil spirit and keep him in outer darkness. Under the influence of such a theory men's consciences are often at election time reconciled to tricks which in more sober moments they would promptly condemn. Yet in the main the good sense of the American people has kept them from acting upon such a one-sided view of the case; and it is for this reason that our political history has not been, like that of the old Italian republics, a dismal record of wholesale proscriptions and reversals of policy, culminating in the loss of authority on the part of the government and of liberty on the part of the citizens. To insure the stability of a civilized state, it is necessary that the liberty of individuals and the authority of the community should be alike sustained; and to this end nature seems to have made provision that in a free society, where people's thoughts and wishes can find ready expression, a fair balance shall be preserved between the votes that would extend the powers of government and those that would limit them. Says the sentry in "Iolanthe,"

"I often think it comical,

How Nature always does contrive

That every boy and every gal, 
That's born into the world alive,

Is either a little Liberal

Or else a little Conservative."

If we were to take a hint from mathematical physics we might regard this curious fact as a case under the general law of deviations from an average. Out of a thousand shots fired at a target the deviations in the one direction will very nearly counterbalance those in the other. So in a political society, where free aim can be taken toward the course of action most beneficial to the community, the distribution of opinions will be found to follow the same law. The line of average deviation will be swayed now a little to one side, now a little to the other, and the resultant course will be remarkably steady; it will express itself in what we call a conservative and moderate policy. For this reason there is no form of political society so strong, so peaceful, so adaptable, so likely to endure, as an intelligent democracy. It is repression that calls forth radicalism. It is in the unwholesome soil of despotism that anarchist weeds spring up. When the states general are not assembled for nearly two centuries, and class legislation meanwhile goes on briskly, it is time to look out for a reign of terror.

In American history the revolutions which have been dreaded by many good people, when there has occurred a change of party supremacy, as in I8OI, in 1829 , and in 1885 , have in general not happened. In the single instance in which a violent convulsion has resulted, in $\mathrm{I} 86 \mathrm{I}$, the exception was of the kind that proves the rule, for the trouble was caused by the existence of negro slavery, an institution utterly incompatible with the spirit of true democracy. In the other 
instances moderation has prevailed for two reasons: first, the winning party has usually owed its victory to the transfer of relatively independent votes from the opposite party, and such transferred votes are likely to act as a potent conservative influence with the winning party; secondly, there are certain instincts which govern the party in power as a responsible agent, and certain other instincts which govern the party in opposition as an irresponsible critic; and when the party in opposition becomes the party in power, it passes under the sway of the former group of instincts, and any tendency to push matters to extremes is thus powerfully checked. These points were illustrated in the administration of Jefferson. The Republican victory of 1800 was won partly by the aid of Federalist votes that in 1796 had been given to Adams. The strong Federalist measures of Hamilton had now been for several years in successful operation; they had become part of our system of government, and to have laid violent hands upon them would have been to transfer thousands of votes back to the Federalists in I804. Moreover, when Jefferson came to be responsible for the conduct of affairs, he could feel the usefulness of many features in the Federalist scheme which he had formerly opposed. As a Republican and a strict constructionist Jefferson had no right to double, and more than double, the area of the United States by the purchase of Louisiana. So we see him becoming a most hardy loose constructionist for the occasion, and pushing the doctrine of "implied powers" to an extreme from which the Federalists shrink back in horror. For the next dozen years we see the Republician party absorbing and 
appropriating what was best in Federalism, and becoming more and more the national party, while the Federalists, losing their hold upon the people, sink into the position of a sectional party and at length dwindle into a faction. First it was John Quincy Adams, prince and protagonist of mugwumps, who upheld Jefferson in the embargo; then it was Daniel Webster, who refused to lend countenance to the Hartford convention; and so the great party of Washington and Hamilton went to pieces until, in 1820 , the victors could afford to be magnanimous, and Rufus King was reëlected to the United States Senate through the aid of Martin Van Buren. As Federalist candidate for the presidency in 1816 , King had received the electoral votes of Massachusetts, Connecticut, and Delaware. In I 820 there was no candidate to take the field against Monroe. In 1824 the four candidates were so-called Republicans. In 1828 the election of Jackson over Adams was the victory of the West over the East, of the backwoodsman over the Harvard professor, of the so-called "man of the people" over the so-called "aristocrat," rather than the victory of one definite and avowed scheme of public policy over another. Nevertheless, by 1828 , the old issues having disappeared, new issues had arisen, and were really, though perhaps not distinctly, involved in the election. The administration of Adams had raised such new issues. The rapid settlement of the Western country was revealing the urgent need of better means of communication. The genius of George Stephenson had already devised the means of dealing with such a problem, and private enterprise, laying thousands of miles of iron rails, was soon to supply the need most 
effectually. But meanwhile it was quite natural that President Adams should take his cue from the wonderful roads and bridges and aqueducts built by the ancient Romans with money raised by taxation, and insist that Americans might well do likewise and thus bring together the distant sections of their vast country. This was the policy of "internal improvements." The end aimed at was a broad, a national, a noble end. It was only the method of attaining it that was questionable. There were some who deemed it a method more in harmony with the political ideas of ancient Romans than with those of modern Americans; but before the question could be settled by political argument the immense capabilities of private enterprise had been so clearly demonstrated that, for the most part, the policy of "internal improvements" has had to stand upon the defensive.

This was one of the leading issues raised during the administration of John Quincy Adams. Closely connected with it was the question of the tariff. Since the War of I8I 2 had made it difficult to obtain manufactured goods from abroad, the scarcity had served as a stimulus to sundry American manufactures, and the protectionist theory had begun to make powerful converts, among them Henry Clay. Mr. Clay advocated the policy of raising by protective duties more revenue than was needed for the ordinary expenses of administration, in order that there might be a surplus to be spent in building roads and dredging rivers; and he recommended this policy to many people by baptizing it "the American system." Then there was the question as to the continuance of the national bank, in which the government was 
itself a stockholder. This did not become a burning question until late in Jackson's first term. The extent to which old Federalist ideas had been adopted or acquiesced in by the Republicans was well shown in the fact that the bill for rechartering the bank in 1816 was signed by President Madison. But Madison's acquiescence was largely due to the want of any definite alternative policy; and there were many who regarded the bank rather as a temporary makeshift, to be endured for the moment, than as a beneficent institution to be fastened permanently upon the country.

Upon these three great questions of internal improvements, tariff, and bank, the all-embracing Republican party became divided between 1824 and 1832. The followers of Adams and Clay came to be distinguished as National Republicans, and this title indicated their strong point. Their policy commended itself, not only to those who believed it to be economically sound, but to many more who felt it desirable that above all things the national government should be strong. Such people inherited the tendencies of the original Federalists. They were inclined to construe liberally the implied powers of the Constitution, because they felt that the government needed such implied powers, in order to ward off the dangers of nullification and secession which were then looming upon the horizon. This was the strong point of the National Republicans. It was this that gave them the powerful support of $\mathrm{Mr}$. Webster, who was by no means blind to the economic unsoundness of the so-called American system. On the other hand, those who now began acting in 
opposition to the National Republicans at length accepted the name of Democrats, which had formerly been applied to Jefferson's followers by their opponents as a term of disparagement. In the days when Jefferson led the opposition, and the guillotine was at work in Paris, the word democracy seemed to smack of Jacobinism; but in the days when Andrew Jackson stood for government by the people, it had a pleasant sound. The Democrats were right in thinking themselves the genuine followers of Jefferson, and they saw clearly the weak side of the National Republicans, whose doctrines of tariff, bank, and improvements opened the door for limitless jobbery and iniquitous class legislation, and might easily become fraught with serious danger to government by the people and for the people.

The new division between parties in Jackson's first term was not accomplished in a moment. People did not at once array themselves in opposite ranks. There was doubt and hesitation. General principles were then, as now, complicated and obscured by real or fancied local interests. But by $1_{32}$ the Democrats had become solidly welded together into a party with a rational and well-defined policy, and with leaders of great ability and influence, as variously exemplified in Jackson, Benton, Van Buren, and Blair. They were opposed to the theory of paternal government which formulated itself in internal improvements, tariff, and bank; and in order to sustain their position, they were inclined to construe the Constitution strictly, and maintain that its implied powers did not extend so far as to justify such a theory. 
Our survey of the political situation in $183_{2}$ is, however, not yet complete. We have not yet taken into the account the peculiar relations of the people of the Southern states toward the two new parties, as it was affected, whether directly or indirectly, whether avowedly or tacitly, by the existence of their peculiar institution, negro slavery. From the outset Southern politicians were quick in perceiving that the security of their system of slavery depended upon that interpretation of the Constitution which should restrict as far as possible the implied powers to be exercised by the federal government. Herein, as strict constructionists, they might seem to have been in harmony with the Jackson Democrats as against the National Republicans. But there was no such harmony. When South Carolina in $\mathrm{r}_{32}$ flung into the political arena the gauntlet of nullification, she found Jackson and his Democrats even more stanch in defence of the Union than Clay and his National Republicans. At that supreme moment Daniel Webster, whose political existence was identified with defence of the Union, was in alliance with Jackson, while Clay was dallying and temporizing with Calhoun. In order to explain this we must take our start from the South, and see how the political situation in ${ }^{8} 83_{2}$ presented itself to the Southern people. We know what was the attitude of Calhoun and of South Carolina. They represented the impulse which thirty years later drove the Southern people into rebellion. But there was also in the Southern states a mass of political beliefs and sentiments which, without agreeing with Calhoun and with South Carolina, agreed still less with Jackson and Webster and the North. If we would under- 
stand the course of events that led to the overthrow of the Democrats in 1840 , we must look for a moment into the history of this current of Southern opinion that was loath to go with Calhoun, but felt itself in honour bound to make protest against coercion as threatened by President Jackson. It was the same current of opinion and sentiment that in I86I was loath to go with Jefferson Davis, but felt itself in honour bound to resist coercion as exercised by President Lincoln. There was much of this feeling in the South, and it was especially strong in the border states. It would never take the lead in a movement toward secession, but might easily be driven into such a movement as a choice between conflicting alternatives. Nowhere was this feeling stronger than in Virginia, and in no public man was it more completely exemplified than in John Tyler, tenth President of the United States. For studying the sources and the growth of this feeling, there is no better text-book than the "Letters and Times of the Tylers," - two stout octavos published at Richmond in I884 and I885, edited by one of the President's younger sons, Mr. Lyon Gardiner Tyler, president of William and Mary College. This interesting book gives us a sketch of the political history of the United States for a hundred years, as viewed by the intelligent and public-spirited members of one of the leading families of Virginia. The elder John Tyler, born in 1747 , was associated with Madison in I 785 in the resolution which secured a conference of delegates at Annapolis in the following year, and thus led the way toward the federal Convention. When the federal Constitution was laid before the people, 
however, Mr. Tyler was one of those who thought that it encroached too much upon state rights, and in the state convention of 1788 he was conspicuous among the opponents of ratification. He was one of those, moreover, who believed that the assent of Virginia to the Constitution could not have been secured but for the belief of many of the delegates that the right of the state to withdraw peaceably from the Union, in case it should ever see fit to do so, was not really surrendered. For the twenty years from I 788 to $1808 \mathrm{Mr}$. Tyler was judge of the general court of Virginia, from I808 to I8I I he was governor of Virginia, and from I8I I until his death in I8 13 he was judge of the United States district court for Virginia. His son, the future President, was born at the homestead at Greenway, on the 29th of March, I790. In early boyhood he attended the small school kept by a Mr. McMurdo, who was so diligent in his use of the birch that in later years President Tyler said "it was a wonder he did not whip all the sense out of his scholars." At the age of eleven young Tyler was one of the ringleaders in a rebellion in which the despotic McMurdo was overpowered by numbers, tied hand and foot, and left locked up in the schoolhouse until late at night, when a passing traveller effected an entrance and released him. On complaining to Judge Tyler, the indignant schoolmaster was met with the apt reply, "Sic semper tyrannis!" The future President was graduated at William and Mary in I807. At college he showed a strong interest in ancient history. He was also fond of poetry and music, and, like Thomas Jefferson, was a skilful performer on the violin. In I809 
he was admitted to the bar, and had already begun to obtain a good practice when he was elected to the legislature, and took his seat in that body in December, i8II. He was here a firm supporter of $\mathrm{Mr}$. Madison's administration, and the war with Great Britain, which soon followed, afforded him an opportunity to become conspicuous as a forcible and persuasive orator. One of his earliest public acts is especially interesting in view of the famous struggle with the Whigs, which in later years he conducted as President. The charter of the first bank of the United States, established in I79I, was to expire in twenty years, and in $181 \mathrm{I}$ the question of renewing the charter came before Congress. The bank was very unpopular in Virginia, and the assembly of that state, by a vote of 125 to 35 , instructed its senators at Washington, Richard Brent and William E. Giles, to vote against a recharter. The instructions denounced the bank as an institution, in the founding of which Congress had exceeded its powers and grossly violated state rights. Yet there were many in Congress who, without approving the principle upon which the bank was founded, thought the eve of war an inopportune season for making a radical change in the financial system of the nation. Of the two Virginia senators, Brent voted in favour of the recharter, and Giles spoke on the same side, and although, in obedience to instructions, he voted contrary to his own opinion, he did so under protest. On January I4, I812, Mr. Tyler, in the Virginia legislature, introduced resolutions of censure, in which the senators were taken to task, while the Virginia doctrines, as to the unconstitutional char- 
acter of the bank and the binding force of instructions, were formally asserted.

Mr. Tyler was reëlected to the legislature annually, until in November, 1816, he was chosen to fill a vacancy in the United States House of Representatives. In the regular election to the next Congress, out of two hundred votes given in his native county, he received all but one. As a member of Congress he soon made himself conspicuous as the most rigid of strict constructionists. When Mr. Calhoun introduced his bill in favour of internal improvements, Mr. Tyler voted against it. He also voted against the proposal for a national bankrupt act. He condemned, as arbitrary and insubordinate, the course of General Jackson in Florida, and contributed an able speech to the long debate over the question as to censuring that gallant commander. He was a member of a committee for inquiring into the affairs of the national bank, and his most elaborate speech was in favour of Mr. Trimble's motion to issue a scire facias against that institution. On all these points Mr. Tyler's course seems to have pleased his constituents ; in the spring election of 1819 he did not consider it necessary to issue the usual circular address, or in any way to engage in a personal canvass. He simply distributed copies of his speech against the bank, and was reëlected to Congress unanimously.

The most important question that came before the sixteenth Congress related to the admission of Missouri to the Union. In the debates over this question, Mr. Tyler took extreme ground against the imposition of any restrictions upon the extension of slavery. At the same time he declared himself on 
principle opposed to the perpetuation of slavery, and he sought to reconcile these positions by the argument that in diffusing the slave population over a wide area the evils of the institution would be diminished and the prospects of ultimate emancipation increased. "Slavery," said he, " has been represented on all hands as a dark cloud, and the candour of the gentleman from Massachusetts (Mr. Whitman) drove him to the admission that it would be well to disperse this cloud. In this sentiment I entirely concur with him. How can you otherwise disarm it? Will you suffer it to increase in its darkness over one particular portion of this land, till its horrors shall burst upon it? Will you permit the lightnings of its wrath to break upon the South, when by the interposition of a wise system of legislation you may reduce it to a summer's cloud?" New York and Pennsylvania, he argued, had been able to emancipate their slaves only because they were so few. Dispersion, moreover, would be likely to ameliorate the condition of the black man, for by making his labour scarce in each particular locality, it would increase the demand for it, and would thus make it the interest of the master to deal fairly and generously with his slaves. To the obvious objection that the increase of the slave population would fully keep up with its territorial expansion, he replied by denying that such would be the case. His next argument was that if an old state, such as Virginia, could have slaves, while a new state, such as Missouri, was to be prevented by federal authority from having them, then the old and new states would at once be placed upon a different footing, which was contrary to the spirit of the Constitution. If Congress could thus 
impose one restriction upon a state, where was the exercise of such a power to end? Once grant such a power, and what was to prevent a slaveholding majority in Congress from forcing slavery upon some territory where it was not wanted? Mr. Tyler pursued the argument so far as to deny "that Congress, under its constitutional authority to establish rules and regulations for the territories, had any control whatever over slavery in the territorial domain." He was unquestionably foremost among the members of Congress in occupying this extreme position. When the Missouri Compromise bill was adopted by a vote of I 34 to 42 , all but 5 of the nays were from the South, and from Virginia alone there were I 7, of which Mr. Tyler's vote was one. The Richmond Enquirer of March 7, I 820, in denouncing the compromise, observed, in language of prophetic interest, that the Southern and Western representatives now "owe it to themselves to keep their eyes firmly fixed on Texas; if we are cooped up on the north, we must have elbow-room to the west."

Mr. Tyler's further action in this Congress related chiefly to the question of a protective tariff, of which he was an unflinching opponent. In 1821 , finding his health seriously impaired, he declined a reëlection, and returned to private life. His retirement, however, was of short duration, for in 1823 he was again elected to the Virginia legislature. Here, as a friend to the candidacy of Mr. Crawford for the presidency, he disapproved the attacks upon the congressional caucus begun by the legislature of Tennessee in the interests of Andrew Jackson. The next year he was nominated to fill a vacancy in the United States Senate, but 
Littleton Tazewell was elected over him. He opposed an attempt which was made about this time to remove William and Mary College to Richmond, and was afterward made successively rector and chancellor of the college, which prospered signally under his management. In December, 1825, he was chosen by the legislature to the governorship of Virginia, and in the following year he was reëlected by a unanimous vote. As the strict constructionists were now becoming gradually united in opposition to the policy of President Adams, many members of Crawford's party, under the lead of John Randolph, went to swell the ranks of the Jacksonians, while others, among whom Mr. Tyler was one of the most distinguished, maintained a certain independence in opposition. It is to be set down to Mr. Tyler's credit that he never attached any importance to the malicious story, believed by so many Jacksonians, of a corrupt bargain between Adams and Clay. A slander of somewhat similar character was soon to be aimed at himself. Soon after the meeting of the Virginia legislature, in December, 1826, the friends of Clay and Adams combined with the members of the opposite party who could no longer endure Randolph's crazy freaks, and thus Governor Tyler was elected to the United States Senate by the narrow majority of I 15 votes to IIO. Some indiscreet friends of Jackson now sought to show that there must have been some secret and reprehensible understanding between Tyler and Clay, but the attempt failed utterly. It is very interesting, however, to observe that Tyler owed his seat in the Senate to the followers of the man with whom he was hereafter to enter into such an extraordinary alliance. 
In the Senate Mr. Tyler took a conspicuous stand against the, so-called "tariff of abominations," which even Benton and Van Buren, who were not yet in 1828 quite clear as to their proper attitude, were induced to support. There was thus some ground for Tyler's opinion, expressed at this time, that the Jacksonians were not really orthodox defenders of strict construction. It was on the occasion of Jackson's famous veto of the Maysville turnpike bill, May 27, 1830, that this most rigorous stickler for constitutional propriety found himself for the moment drawn toward the President. It was quite proper and characteristic for him to attack the irregularity of Jackson's appointment of commissioners to negotiate a commercial treaty with Turkey, without duly informing the Senate; but at the same time he showed good will toward the President by voting in favour of confirming the appointment of Van Buren as minister to Great Britain. In the presidential election of $183^{2}$ he supported Jackson, but only as a less objectionable candidate than Clay, Wirt, or Floyd. The preference accorded to Jackson over Floyd would indicate that the President's immortal Union toast had not seriously alarmed Mr. Tyler, who disapproved of nullification and condemned the course of South Carolina as rash and ill-considered. Herein Tyler was wiser than Calhoun. On the question of the tariff the South had really a strong case, and to throw the gauntlet of nullification into the arena was simply to offer the chances of victory to the North: But when it came to suppressing nullification with the strong hand, Mr. Tyler's attitude was curiously significant. He was emphatic in his opposition to President Jackson's proclamation. He denounced it as a "tremen- 
dous engine of federalism," tending toward the "consolidation" of the states into a single political body. His attitude in 1833 was substantially the same as in I 86 I, when secession had become a grim reality. In the earlier crisis, as in the later, he tried to stand upon the ground that while secession might be wrong, coercion was a greater wrong. This was the mental attitude that in I86I led Virginia to join the Southern Confederacy and made Mr. Tyler in the last year of his life a member of the Confederate Congress. And as in I86I the secession of Virginia was preceded by the assembling of a peace convention of border states, with Tyler for its president, so now in 1833 he undertook to play the part of mediator between Clay and Calhoun, and in that capacity earnestly supported the compromise tariff bill introduced by the former in the Senate on the I 2 th of February. In this measure, which was opposed by Mr. Webster as an ill-timed and mischievous concession to the threats of South Carolina, we may see a premonitory symptom of that alliance between the followers of Tyler and Clay which soon resulted in the formation of the Whig party. At the same time occurred the sudden and decisive break between Tyler and Jackson. In a special message to Congress, the President asked for full and explicit authority to use the army and navy, if need be, for the purpose of suppressing armed insurrection. Congress readily responded with the so-called "Force Bill," and here Mr. Tyler showed that he had the courage of his convictions. When the bill was put to vote in the Senate, on the 2oth of February, some of its Soithern opponents were conveniently absent, others got up and went out in order to avoid putting themselves on record. The 
vote, as then taken, stood: Yeas, thirty-two; Nay, one, to wit, John Tyler.

It was thus on the question of the right of the federal government to use force in suppressing nullification that the Southern strict constructionists discovered that there was no room for them within the Democratic party as then constituted under the lead of Jackson, Van Buren, Benton, and Blair. In this conclusion the peculiar features of Jackson's attack upon the United States Bank only confirmed them. When it came to the removal of the deposits, Mr. Tyler's break with the administration was thorough and final. As we have seen, he was no friend to the bank; he had fought against it on every fitting occasion, since the beginning of his public career. And now, in 1834 , he declared emphatically, "I believe the bank to be the original sin against the Constitution, which, in the progress of our history, has called into existence a numerous progeny of usurpations. Shall I permit this serpent, however bright. its scales or erect its mien, to exist by and through my vote?" Nevertheless, strongly as he disapproved of the bank, Mr. Tyler disapproved still more strongly of the methods by which President Jackson assailed it. There seemed at that time to be growing up in the United States a spirit of extreme unbridled democracy quite foreign to the spirit in which our constitutional government, with its carefully arranged checks and limitations, was founded. It was a spirit that prompted mere majorities to insist upon having their way, even at the cost of overriding all constitutional checks and limits. This wild spirit possessed many members of Jackson's party, and it found expression in what Mr. Ben- 
ton grotesquely called the "demos Krateo" principle. A good illustration of it was to be seen in Benton's argument, after the election of 1824 , that Jackson, having received a plurality of electoral votes, ought to be declared President, and that the House of Representatives, in choosing Adams, was really "defying the will of the people." In similar wise President Jackson, after his triumphant reëlection in 1832 , was inclined to interpret his huge majorities as meaning that the people were ready to uphold him in any course that he might see fit to pursue. This feeling no doubt strengthened him in his determined attitude toward the nullifiers, and it certainly contributed to his arbitrary and overbearing method of dealing with the bank, culminating, in 1833 , in his removal of the deposits. There was ground for maintaining that in this act the President exceeded his powers, and it seemed to illustrate the tendency of unbridled democracy toward practical despotism, under the leadership of a headstrong and popular chief. Mr. Tyler saw in it such a tendency, and he believed that the only safeguard for constitutional government, whether against the arbitrariness of Jackson or the latitudinarianism of the Whigs, lay in a most rigid adherence to strict constructionist doctrines. Accordingly, in his speech of the 24th of February, 1834, he proposed to go directly to the root of the matter and submit the question of a national bank to the people in the shape of a constitutional amendment, either expressly forbidding or expressly allowing Congress to create such an institution. According to his own account, he found Clay and Webster ready to coöperate with him in this course, while Calhoun held aloof. Nothing came of 
the project; but it was now easy to see the alliance fast maturing between the Northern National Republicans and those Southerners who agreed with Tyler. In December, 1834, as member of a committee for investigating the management of the bank, Mr. Tyler brought in an elaborate report which seems to have been a very fair statement of the case. It did not sustain Jackson's charges of mismanagement, and was accordingly attacked by Benton as a partisan defence of the bank. This doubtless served to confuse the minds of people as to Tyler's real attitude. Before the smoke of the battle had cleared away, people would not distinguish between disapproval of Jackson's methods and approval of the bank; they would consider the one as equivalent to the other, and so they did. An incident which occurred the next year served to confirm this view. On Mr. Clay's famous resolution to censure the President for the removal of the deposits, Tyler had voted, along with Webster, in the affirmative. While Benton's resolutions for expunging the vote of censure were before the Senate, the Democratic legislature of Virginia instructed the two senators from that state to vote in the affirmative. As to the binding force of such instructions Mr. Tyler had long ago, in the case of Giles and Brent above mentioned, placed himself unmistakably upon record. His colleague, Benjamin Watkins Leigh, was known to entertain similar views. On receiving the instructions, both senators refused to obey them. Both voted against the expunging resolution, but Leigh kept his seat, while the rigidly consistent Tyler resigned and went home. The result of this for Leigh was to be retirement to private life; for Tyler it was to be elevation to the presidency. 
He had already been recommended for the vicepresidency by the legislatures of several Southern states. During the year 1834 the Whig party came into existence. At the North the National Republicans, the party of Clay and Webster, were beginning to call themselves Whigs; while the Southern strict constructionists gladly took the name of "State Rights Whigs." Between these two wings of the new party there was no bond of union whatever except their common hostility to the Jackson Democrats. Their alliance was as unnatural as that of Fox and North against Lord Shelburne in 1783 , or as that of John Bright with Lord Salisbury against Mr. Gladstone scarcely a decade ago. The protective theory of government, with its tariff, bank, and internal improvements, which was the fetich of the Northern Whigs, was to the Southern Whigs a device of Belial. Even in their common hatred of Jackson they did not stand upon common ground; for the Northern Whigs hated him for his stanch opposition to paternal government, while the Southern Whigs hated him for the severity with which he frowned upon nullification. The nearest approach to real sympathy between the two discordant allies was furnished by Tyler and Webster, in so far as they were agreed for the moment in condemning the violence of Jackson's proceedings in the particular case of the bank. And it was in this one point of sympathy that the name "Whig" had its origin. They called themselves Whigs because they saw fit to represent Jackson as a sort of unconstitutional tyrant, like George III., and for a moment they tried to stigmatize Jackson's followers as "Tories," but this device was unsuccessful. 
The alliance was so unnatural that it took some time to complete it. In $18{ }_{3} 6$ there was no agreement upon a candidate for the presidency. The "State Rights" Whigs nominated Hugh Lawson White of Tennessee for President, and John Tyler for Vicepresident. The Northern Whigs, in the hope of gathering votes from as many quarters as possible, thought it best to put forward some more colourless candidate than their real leader, Mr. Clay, and accordingly they nominated General William Henry Harrison. This gentleman was born in Berkeley, Virginia, February 9, I773. His father, Benjamin Harrison, was one of the signers of the Declaration of Independence, was twice elected governor of Virginia, and in the state convention of 1788 was allied with the elder Tyler in opposing the adoption of the federal Constitution. William Henry Harrison was educated at Hampden Sidney College, Virginia, but broke off his studies in I79I to take a commission in the army on the Western frontier, commanded by Anthony Wayne. Having distinguished himself for gallantry and for executive ability, he was in 1800 appointed superintendent of Indian affairs and governor of the Indiana territory, comprising the present states of Indiana, Illinois, Michigan, and Wisconsin. He held that office for several years, and when the Indian War broke out prematurely, in I8I I, he defeated Tecumseh's brother, the Prophet, on the 7 th of November of that year, in a bloody and decisive battle at Tippecanoe, on the upper Wabash. In the autumn of 1812 he was appointed to the chief command of the United States forces in the Northwest, and on October 5, 1813, he won the battle of the 
Thames over the allied British and Indians commanded by General Proctor and Tecumseh. This battle, in which Tecumseh was killed and nearly the whole British force surrendered, was decisive of the war in the Northwest, and the two victories gave General Harrison a military reputation second only to Jackson's. In 1816-1819 he was a member of Congress. In 1819 he was chosen to the senate of Ohio, and in 1822 was again a candidate for Congress, but was defeated because of his vote against the admission of Missouri to the Union as a free state. In 1824 he was chosen to the United States Senate, in 1828 President Adams sent him out as minister to the United States of Colombia, and in the following year he was recalled by President Jackson, and retired to his farm at North Bend, near Cincinnati. He was a good soldier and a thoroughly upright and trustworthy man. Upon the political questions that were dividing Whigs from Democrats in 1836 , he had done little or nothing to commit himself, and in nominating him for the presidency the Whigs sought to turn to their own uses the same kind of popular enthusiasm by which Jackson had profited. But the ill-organized opposition had no chance of winning a victory over the solid Democratic column. Many votes were thrown away. South Carolina, still fighting her own battle, voted for Person Mangum, a State Rights Whig. Massachusetts voted for Daniel Webster. Mr. White obtained the I I votes of Georgia and the 15 of Tennessee, for the latter state, in spite of her reverence for Jackson, did not approve his policy of coercion and could not be induced to support Van Buren. General Harrison carried Vermont, 
New Jersey, Delaware, Maryland, Kentucky, Ohio, and Indiana, - in all 73 votes. The opposition had hoped that, with so many candidates in the field, there would be enough bolting and scattering to prevent a choice by the people, and throw the election into the House of Representatives. But Mr. Van Buren won an easy victory. He received i 70 electoral votes, a majority of 46 over the other candidates taken together. The result of the canvass for the vicepresidency was curious. Colonel Richard Johnson, the Democratic candidate, obtained exactly half the number of votes in the electoral college, so that there was no choice. For the only time in our history the election devolved upon the Senate, which proceeded to choose Colonel Johnson. What more especially concerns us here is the vote for Mr. Tyler. He failed to carry his own state, for Virginia was now firmly Democratic, and remained so until r860; but he ran ahead of his fellow-candidate, Mr. White, and, besides Tennessee and Georgia, he received the votes of Maryland and South Carolina.

The result of this election left Mr. Tyler for the next two years in retirement, but one opinion of his, very clearly pronounced at this time, is worth quoting as an illustration of the independence of judgment which he sometimes manifested. The followers of Calhoun were bringing forward in Congress what was known as the "gag resolution" against all petitions and motions relating in any way to the abolition of slavery. Mr. Tyler condemned this measure as impolitic on the part of the slaveholders, because it yoked together the question as to the right of petition and the question as to slavery, and thus, by presenting the slave power 
as hostile to free speech, gave a distinct moral advantage to the Abolitionists. The spirit of slavery, however, was true to its own barbarous instincts when it rejected this prudent counsel.

In the spring of $1838 \mathrm{Mr}$. Tyler was returned to the Virginia legislature, and in the following winter his friends put him forward for reëlection to the United States Senate. In the memorable contest that ensued, in which William Rives was his principal competitor, the result was a complete deadlock, so that the legislature adjourned without making a choice.

Meanwhile the financial crisis of 1837 - the most severe that has ever been known in this country - had wrecked the administration of President Van Buren. It was believed at the time that this frightful tempest in the commercial world was wholly or chiefly due to Jackson's assaults upon the United States Bank, and this opinion has been so confidently stated as a fact, and so often reiterated, that it has come to be one of the commonplaces of history. Yet, like many other commonplace assertions in history, it is only partially true. The causes of the panic of 1837 lay deeper than any acts of any administration. The seeds of distress had been so plentifully sown that an abundant crop must have been garnered about that time, no matter whether a Whig or a Democrat were occupant of the White House, no matter whether the public funds were deposited in one great bank or in fifty small ones. Since 1820 the increase of the country in wealth and population, and the rapidity of expansion westward, had been wonderful. Tennessee had nearly doubled in population, Ohio had more than doubled, Indiana had more than trebled, Mississippi had increased four- 
fold, Missouri fivefold, Illinois sevenfold, Michigan twentyfold. A transformation was going on in the cities. In 1820 New York and Philadelphia, with populations a little over 100,000 , had hardly ceased to look like country towns; by 1835 the former had passed 250,000 and the latter 200,000 , so that they were beginning to take on the appearance of large cities. In 1820 the national debt was $\$ 90,000,000$; by 1835 every cent of it was paid and there was a surplus in the treasury, a fact which powerfully impressed people's imaginations, both here and in Europe. This prosperity was the cause of endless self-glorification, and it was apt to be ascribed to American institutions in a greater degree than to the natural resources of the country. It began to seem as if nothing were impossible to American enterprise, and confidence grew into recklessness. It was an era of road-building. In 1820 it cost $\$ 88$ to carry a ton of freight from Buffalo to Albany; in 1825 the Erie Canal was finished, and that ton could be carried that distance for $\$ 2 \mathrm{I} .50$; in 1835 it could be carried for $\$ 6.5$ o. That single fact gave an unprecedented stimulus to the growth alike of New York and of the West. In 1830 there were 23 miles of railroad in the United States; in 1836 there were I 273 miles. During the same six years the steamboat tonnage on our Western rivers increased nearly sixfold, and the cotton crop in the Southwestern states was doubled, while the price of raw cotton rose from ten to twenty cents a pound. Such sudden and surprising changes quite disturbed people's conceptions of value and bewildered them in their calculations. The great West began to seem an El Dorado, and so long as desired land was in some new region, it 
acquired an imaginary value, without much reference to its real relations to the development of the country, which, of course, time alone could disclose. The valuation of real estate in Mobile in I83 1 was little more than a million dollars; in 1837 it was more than 27 millions; in 1846 it had shrunk to less than 9 millions. Assuming that the increase from a million in $18_{3} 1$ to nearly 9 millions in 1846 represents real growth, we may regard the greater part of the intervening figure of 27 millions as representing the heated fancies of men in the Atlantic states and in Europe anxious to invest their money where it could make them suddenly rich. The extent of the mania in Europe was indicated by the striking fact that although between I830 and I 837 we bought from foreign countries \$I 40,000,000 worth of merchandise in excess of what we sold to them, we received from them at the same time $\$ 45,000,000$ in specie in excess of what we paid to them. The account was balanced by the shares taken by European capitalists in American enterprises.

This rage for speculation led to immense purchases of Western public lands. At that time any one who chose could buy these lands at the fixed price of $\$ I .25$ per acre, whether he intended to settle upon them or not. Speculators began buying extensive tracts in order to sell them at a greatly advanced price. Between 1820 and 1829 the annual sales of public lands by the United States government averaged about $\$ 1,300,000$. Between 1830 and 1834 they averaged from 3 to 5 millions. In 1835 they leaped up to I 5 millions, and in 1836 to 25 millions. The money spent in buying these remote unimproved lands, and in taking stock in railroads projected for reaching 
them, was thus abstracted from the ordinary and safe occupations of industry and commerce. There was a great demand for ready money, and in the prevailing spirit of boundless confidence it was met by an enormous increase of banks and bank credits. Between I 830 and 1836 the banking capital of the United States rose from 60 to 250 millions, the loans and discounts from 200 to 450 millions, and the note circulation from 60 to 140 millions. Thus the elements of a prodigious commercial crisis were all at hand. There was the wholesale dealing in property that had only fictitious values; there was the wholesale creation of indebtedness, and the attempt to pay it, Micawberlike, with paper promises to pay. Perhaps Jackson's withdrawal of the government deposits from the United States Bank, and distribution of them among fifty state banks, may have helped to increase the mania for speculation; but it is now apparent that the madness was already beyond control and fast hurrying to a crisis.

A far worse measure, for which both parties in Congress were responsible, and which Jackson ought to have vetoed, was the distribution of the surplus. The extinction of the national debt came to diminish the outgo just as the great sales of public lands came to swell the income; and so in 1836 there was a surplus of $\$ 37,000,000$, which Congress decided to divide among the states and pay over in four quarterly instalments, beginning on New Year's of 1837 . The prospect of this largess simply added to the general craze.

By the summer of 1836 the bubble had been blown to such dimensions as perhaps had not been seen since the celebrated South Sea bubble of I 720 . To prick and explode such airy nothings, it is only necessary 
that a few purchasers should begin to awake to their delusion and a few creditors should begin to ask for hard cash. By 1836 there were others than Martin Chuzzlewit who had learned to their cost that Aladdin's lamp was not to be found in malarial swamps on the Mississippi. Just then there was a creditor who made demands, and that creditor was the United States government. On the I I th of July the Secretary of the Treasury issued the famous "specie circular," requiring payments for public lands to be made in specie. Stringency of the money market had already begun to be felt, because the issue of paper had not kept pace with the feverish demand. Now the stringency increased with fearful rapidity. The crash began to come when the first quarter of the surplus was paid out by the deposit banks in January. So large a sum of money could not be moved without calling in loans and awakening apprehension. Western banks began calling for specie to pay their debts to the government; confidence died out in Europe, and gold began flowing thither to balance accounts. Prices had become so inflated, and money so hard to get, that mobs in the city of New York shouted for cheap food, and with true mob logic proceeded to destroy a great flour warehouse by way of making flour cheaper. In the course of the spring there was a collapse of prices and a collapse of credit. All over the country the banks suspended payment; great houses and little houses became alike insolvent; widows and orphans who had taken stock in railroads leading to Eden were reduced to live upon charity; coin disappeared, and there was a partial return to barter; a pair of shoes would be paid for in soup tickets or chips 
receivable for drinks of whiskey; in some places men found it hard to get work on any terms.

Such in its main outlines was the crisis of 1837 . A masterly account of it may be found in Shepard's "Van Buren," a little book which seems to me the ablest in all that excellent series of American Statesmen. We have had greater, more brilliant, more interesting Presidents than Mr. Van Buren; but we have never had one with a more thorough grasp of the principles of political economy, or a more adequate and lucid conception of the proper sphere and duties of government. When Mr. Shepard calls his message to Congress on the occasion of the panic one of the greatest of American state papers, his words are not at all too strong. It was natural that the President should be made the scapegoat for the sins of the people. The Whigs had predicted mischief from the overthrow of the national bank. People now attributed the panic to that cause and to the issue of the specie circular. The mischief, they said, was the work of government, and now government must cure it. A few strokes of President Jackson's pen had wrought all the evil, and it must be undone by a few strokes from President Van Buren's. A new bank must be chartered, the specie circular rescinded, and plenty of paper issued. If Van Buren had yielded to this popular clamour, the crisis would very likely have proved as obstinate as that of 1873 , the length of which can plainly be traced to inconvertible paper. In commerce as in medicine, acute mania is easier to deal with than chronic melancholia. Van Buren understood that the disease was not one which government could cure, and he set this forth with admirable courage and force in his message. 
So far from advocating a recharter of the bank, he led in the establishment of the present subtreasury system, by which the government is completely divorced from banking. This was the great achievement of his administration. But the Whigs had naturally taken advantage of the troubles to raise a cry for paternal government, and for the moment they found willing listeners everywhere. There was a general revolt against the hard-hearted administration which had done nothing to relieve the distress of the people. For the single purpose of defeating Mr. Van Buren, all differences of policy were subordinated. In the Whig convention at Harrisburg, which met on the $4^{\text {th }}$ of December, I 839, almost a year before the election, no platform of principles was adopted. The unformulated platform was, "Anything to beat Van Buren." It was now the turn of the Whigs to appeal to the frontier prejudices of the West against the aristocratic East by renominating General Harrison, who in the days of Tecumseh and Tippecanoe had lived in a log cabin and had on his table none of your French champagne, but good hard cider. Naturally Mr. Tyler, as a leader of the Southern or State Rights Whigs, was nominated for the vice-presidency. In the uproarious campaign that followed there was less appeal to sober reason and a more prodigal use of claptrap than in any other presidential contest in our history. The chief

${ }^{1}$ A newspaper clipping, preserved by Dr. Fiske, commenting on the heavy shower that fell upon "Bunker Hill Day," tells of a more notable shower that drenched the procession of September I 7 th, I 840, "the big'gest procession up to that date seen in Boston," wetting the Whigs, the correspondent says, "from one end of the line to the other"; but Stephen C. Phillips went into Faneuil Hall the same night and gave the sentiment, "Any rain but the reign of Van Buren." 
features were long processions in which log cabins mounted on wheels were dragged about and kegs of hard cider were broached, while in stump speeches the heartless Van Buren was accused of having a silver service on his table and otherwise aping British manners. A kind of lilliburlero was sung, with its chorus :-

"For Tippecanoe and Tyler too-Tippecanoe and Tyler too;

And with them we'll beat little Van, Van.

Van is a used-up man;

And with them we'll beat little Van."

Thus borne upon a wave of popular excitement, "Tippecanoe and Tyler too" were carried to the White House. There were 234 electoral votes for Harrison and 60 for Van Buren. But a glance at the figures of the popular vote shows that then, as always in American politics, the approach to equilibrium was too close for a party to presume too much upon the triumph of the moment. Harrison's vote was I,275,0I6; Van Buren's was $1,129,102$; and there was a third candidate, James Birney, who obtained only about 7000 votes, and carried no state. He stood for the abolition of negro slavery, and at that moment counted for little.

The inauguration of the new government in March, I $84 \mathrm{I}$, brought with it some surprises. Perhaps the only distinct pledge to the people during the clamorous canvass had been the promise of civil service reform. That promise had been definite enough to induce some Democrats to vote for the Whig candidates, but it now appeared that the Whig idea of reform agreed substantially with Jackson's; it was summed up in "turning the rascals out." The pressure of office- 
seekers at the White House was so great that some good people thought the worry and turmoil enough to account for President Harrison's death. However that may be, the true cause was pneumonia. He died on the $4^{\text {th }}$ of April, just one month after his inauguration, without having had time to indicate his policy. Among the Northern Whigs, however, there was little doubt as to what that policy ought to be. Mr. Clay was their real leader, and they regarded General Harrison as a mere figurehead candidate, selected for what is called, in political slang, availability. Doubtless most people at the North who voted for Harrison did so in the belief that his election meant the victory of Clay's theory of government in the reëstablishment of the national bank and the increase of tariff duties. Mr. Clay's own course, immediately after the inauguration, showed so plainly that he regarded the election as his own victory, that General Harrison felt called upon to administer a rebuke. "You seem to forget, sir," said he, "that it is I who am President." Harrison offered Clay the Secretaryship of State, and when Clay refused it because he preferred to stay in the Senate, it was given to Daniel Webster.

But whatever President Harrison's policy might have been, there could be no doubt that his sudden death, in raising Mr. Tyler to the presidency, created an unlooked-for situation, which was likely to rob Mr. Clay and his friends of the fruits of their victory. It has been the habit of Whig writers to speak of Mr. Tyler as a renegade, and to slur over the circumstances of his candidacy by declaring that at the time of his nomination his views on public questions, and in particular on the bank, were little known. But the 
sketch of his career here given is enough to show that there was no man in the United States in 1840 whose opinions had been more clearly or more boldly declared; and if the Whigs had sinned in nominating him, they certainly had sinned with their eyes open. In the ill-yoked alliance of which the Whig party was born, the elements of a fierce quarrel were scarcely concealed, and the removal of President Harrison was all that was needed to kindle the flames of strife. "Tyler dares not resist," said Clay; "I'll drive him before me." On the other hand, the new President declared, "I pray you to believe that my back is to the wall, and that, while I shall deplore the assaults, I shall, if practicable, beat back the assailants; " and he was as good as his word. Congress met in extra session, May 3I, I84 I, the Senate standing 28 Whigs to 22 Democrats, the House 133 Whigs to 108 Democrats. In his opening message President Tyler briefly recounted the recent history of the United States Bank, the subtreasury system, and other financial schemes, and ended with the significant words, "I shall be ready to concur with you in the adoption of such system as you may propose, reserving to myself the ultimate power of rejecting any measure which may, in my view of it, conflict with the Constitution, or otherwise jeopard the prosperity of the country; a power which I could not part with, even if I would, but which I will not believe any act of yours will call into requisition." The challenge was promptly accepted by Congress. The ground was cleared for action by a bill for abolishing Van Buren's subtreasury system, which passed both houses and was signed by the President. But an amendment offered by Mr. Clay for the repeal of 
the law of 1836 regulating the deposits in the state banks was defeated by the votes of a small party, led by William C. Rives. The great question then came up. On constitutional grounds, Mr. Tyler's objection to the United States Bank had always been that Congress had no power to create such a corporation within the limits of a state without the consent of the state, ascertained beforehand. He did not deny, however, the power of Congress to establish a district bank for the District of Columbia, and, provided the several states should consent, there seemed to be no reason why this district bank should not set up its branch offices all over the country. Mr. Clay's so-called " fiscal bank" bill of $\mathrm{r} 84 \mathrm{I}$ did not make proper provision for securing the assent of the states, and on that ground Mr. Rives proposed an amendment, substituting a clause of a bill suggested by Thomas Ewing, Secretary of the Treasury, to the effect that such assent should be formally secured. Mr. Rives's amendment was supported not only by several so-called "State Rights Whigs," but also by Senators Richard H. Bayard and Rufus Choate, and other friends of Mr. Webster. If adopted, its effect would have been conciliatory, and it might perhaps have averted for a moment the rupture between the ill-yoked allies. The Democrats, well aware of this, voted against the amendment, and it was lost. The bill incorporating the Fiscal Bank of the United States was then passed by both houses, and on the 16th of August was vetoed by the President. An attempt to pass the bill over the veto failed of the requisite two-thirds majority.

The Whig leaders had already shown a disposition to entrap the President. Before the passage of 
Mr. Clay's bill, John Minor Botts was sent to the White House with a private suggestion for a compromise. Mr. Tyler refused to listen to the suggestion except with the understanding that, should it meet with his disapproval, he should not hear from it again. The suggestion turned out to be a proposal that Congress should authorize the establishment of branches of the district bank in any state of which the legislature at its very next session should not expressly refuse its consent to any such proceeding; and that, moreover, in case the interests of the public should seem to require it, even such express refusal might be disregarded and overridden. By this means the obnoxious institution might first be established in the Whig states, and then forced upon the Democratic states in spite of themselves. The President indignantly rejected the suggestion as "a contemptible subterfuge, behind which he would not skulk." The device nevertheless became incorporated in Mr. Clay's bill, and an impression got abroad that it was put there in order to smooth the way for the President to adopt the measure, but that in his unreasonable obstinacy he refused to avail himself of the opportunity. After his veto of August 16 these tortuous methods were renewed. Messengers went to and fro between the President and members of his cabinet on the one hand and leading Whig members of Congress on the other, conditional assurances were translated into the indicative mood, whispered messages were magnified and distorted, and presently appeared upon the scene an outline of a bill that it was assumed the President would sign. This new measure was known as the "fiscal corporation" bill. Like the fiscal bank bill, it 
created a bank in the District of Columbia, with branches throughout the states, and it made no proper provision for the consent of the states. The President had admitted that a "fiscal agency" of the United States government, established in Washington for the purpose of collecting, keeping, and disbursing the public revenue, was desirable if not indispensable; a regular bank of discount, engaged in commercial transactions throughout the states, and having the United States government as its principal shareholder and federal officers exerting a controlling influence upon its directorship, was an entirely different affair, something in his opinion neither desirable nor permissible. In the "fiscal corporation" bill an attempt was made to hoodwink the President and the public by a pretence of forbidding discounts and loans, and limiting the operations of the fiscal agency exclusively to exchanges. While this project was maturing, the Whig newspapers fulminated with threats against the President in case he should persist in his course; private letters warned him of plots to assassinate him; and Mr. Clay in the Senate referred to his resignation in 1836 , and asked why, if constitutional scruples again hindered him from obeying the will of the people, did he not now resign his lofty position and leave it for those who could be more compliant? To this it was aptly replied by Mr. Rives that "the President was an independent branch of the government as well as Congress, and was not called upon to resign because he differed in opinion with them." Some of the Whigs seem really to have hoped that such a storm could be raised as would browbeat the President into resigning, whereby the government would be temporarily left in the hands of 
William L. Southard, then president pro tempore of the Senate. But Mr. Tyler was neither to be hoodwinked nor bullied. The "fiscal corporation" bill was passed by the Senate on Saturday, September 4, I84I; on

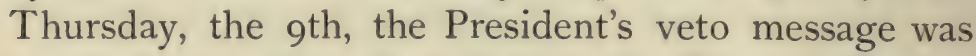
received; on Saturday, the IIth, Thomas Ewing, Secretary of the Treasury, John Bell, Secretary of War, George E. Badger, Secretary of the Navy, John J. Crittenden, Attorney-general, and Francis Granger, Postmaster-general,resigned their places. The adjournment of Congress had been fixed for Monday, the I $3^{\text {th, }}$ and it was hoped that, suddenly confronted by a unanimous resignation of the cabinet and confused by want of time in which to appoint a new cabinet, the President would give up the game. But the resignation was not unanimous, for Daniel Webster, Secretary of State, remained at his post; and on Monday morning the President offered to the Senate for confirmation the names of Walter Forward of Pennsylvania for Secretary of the Treasury; John McLean of Ohio for Secretary of War, Abel P. Upshur of Virginia for Secretary of the Navy, Hugh S. Legaré of South Carolina for Attorney-general, and Charles A. Wickliffe of Kentucky for Postmaster-general. These excellent appointments were duly confirmed.

Whether the defection of Mr. Webster at this moment would have been so fatal to the President as some of the Whigs were inclined to believe may well be doubted; but there can be no doubt that his adherence to the President was of great value. By remaining in the cabinet Mr. Webster showed himself too clear-sighted to contribute to a victory of which the whole profit would be reaped by his rival, Mr. Clay; 
and the President was glad to retain his hold upon so strong an element in the North as that which Mr. Webster represented. Some of the leading Whig members of Congress now issued addresses to the people, in which they loudly condemned the conduct of the President and declared that "all political connection between them and John Tyler was at an end from that day forth." It was open war between the two departments of government. Only a few members of Congress, commonly known as "the corporal's guard," really recognized Mr. Tyler as their leader; but the Democratic members came to his support as an ally against the Whigs. The state elections of I84 I showed some symptoms of a reaction in favour of the President's views, for in general the Whigs lost ground in them. As the spectre of the crisis of 1837 faded away in the distance, the people began to recover from the sudden and overmastering impulse that had swept the country in 1840 , and the popular enthusiasm for the bank soon died away. Mr. Tyler had really won a victory of the first magnitude, as was conclusively shown in 1844 , when the presidential platform of the Whigs was careful to make no allusion whatever to the bank. On this crucial question the doctrines of paternal government had received a crushing and permanent defeat. In the next session of Congress the strife with the President was renewed, but it was now tariff, not bank, that furnished the subject of discussion. The lowering of duties by the compromise tariff of 1833 had now diminished the revenue until it was insufficient to meet the expenses of government. The Whigs accordingly carried through Congress a bill continuing the protective duties of 1833 , and pro- 
viding that the surplus revenue, which was thus sure soon to accumulate, should be distributed among the states. But the compromise act of 1833 , in which $\mathrm{Mr}$. Tyler had played an important part, had provided that the protective policy should come to an end in 1842 . Both on this ground, and because of the provisions for distributing the surplus, the President vetoed the new bill. Congress then devised and passed another bill, providing for a tariff "for revenue, with incidental protection," but still contemplating a distribution of the surplus if there should be any. The President vetoed this bill. Congress received the veto message with indignation, and on the motion of John Quincy Adams it was referred to a committee, which condemned it as an unwarrantable assumption of power, and after a caustic summary of Mr. Tyler's acts since his accession to office, concluded with a reference to impeachment. This report called forth from the President a formal protest; but the victory was already his. The Whigs were afraid to go before the country in the autumn elections with the tariff question unsettled, and the bill was accordingly passed by both houses without the distributing clause, and was at once signed by the President. As a parting menace, the distributing clause was then passed in a separate bill, but a "pocket veto" sufficed to dispose of it. Congress adjourned August 31, 1842, and in the autumn elections the Whig majority of 25 in the House of Representatives gave place to a Democratic majority of $6 \mathrm{I}$.

Here our story must for the present stop, with the total overthrow of the Whig doctrines of paternal government. As the net result of twenty years of political experience, since the election of John Quincy 
Adams had raised new political issues, we find the Whig theory everywhere discomfited. The bank was too completely dead to find any mourners. The protective tariff was reduced to such a point that we were abreast with England in the march toward free trade, and our foreign commerce was beginning to rival that of England, when the Civil War and its war taxes set us back for a while. At the same time the policy of internal improvements remained, as it still remains, on the defensive. Viewed in its large relations, it was a noble victory for the sound Democratic doctrine of "government of the people, by the people, and for the people." The four eminent men who represented this doctrine were Jackson, Van Buren, Benton, and Blair. They also stood for the Union, against all separatist schemes, as strongly and devotedly as Webster and Clay. As for Tyler, while we cannot call him a great man, while for breadth of view and sound grasp of fundamental principles he is immeasurably below Van Buren, at the same time he is not so trivial a personage as his detractors would have us believe. He was honest and courageous, and in the defeat of Mr. Clay's theory of government he played an important and useful part. If he is small as compared with Jackson and Van Buren, he is great as compared with Pierce and Buchanan.

We cannot here consider the close of Mr. Tyler's presidency, because that would introduce a new set of considerations, and our time is now at an end. When the question of the annexation of Texas came into the foreground, the lines were speedily drawn between North and South, as they had not been drawn since 1820. Mr. Tyler and his State Rights Whigs had 
already broken with the Northern Whigs. Now on the Texas question they allied themselves with the Democrats, thus following Calhoun, who had already, in 1838 , after Jackson was out of the way, thought it safest to ally himself with that party. It was natural that all those who wished to defer the solution of the slavery question should sooner or later come to join the party that construed the Constitution as it had been construed by the elder Tyler and the elder Harrison in the convention of $\mathrm{I} 788$. It was this that took the Tyler men over to the Democrats in 1844 . In thus going over, they altered for the worse the character of the Democratic party. In $1844 \mathrm{Mr}$. Van Buren would naturally have been the Democratic candidate for the presidency, but because he bravely opposed the annexation of Texas as a reënforcement to the slave power, he was unable to secure the nomination. This was because Mr. Tyler's State Rights Whigs had joined the Democrats. As Lord Dundreary would say, the tail had now become able to wag the dog. From I 844 the Democratic party, led by Mr. Polk, the first "dark horse," came to be more and more a Southern party. The Northern Whigs, having seen all their economic principles defeated by Mr. Tyler, soon came to have nothing in common save the disposition to save the Union by concessions to the South; and on this plan of campaign they met with their final defeat in I852. At the same time the Democrats became more and more dependent upon Southern support as they lost their Northern leaders. In I 848 we see Mr. Van Buren a candidate for the presidency upon a free-soil platform. By 1856 we see Benton dubious and Blair a Republican. Between 1850 and 1860 
many of the best and most vigorous elements in the old Democratic party of Jackson and Van Buren had gone over to the new Republican party; just as since I 876 we have seen many of the most characteristic elements of the old Republican party of Lincoln and Sumner going over to the Democrats. Whatever may be the merits of the Republican party of to-day, it is no more the party of Lincoln and Sumner than the Federalist party of 18 I 2 was the party of Hamilton and John Adams. Just so with the Democratic party forty years ago. By the subtraction of its original leaders, the Democratic party of Pierce and Buchanan came to be something quite different from the Democratic party of Jackson and Van Buren. It came to be a mere servant of the slave power. The danger which menaces the Republican party to-day is the danger that it may fall under the control of monopolists. Should it turn out to be so, the history of American politics points to the probable result. That history shows with clearness how moderately the evolution of society goes on where the popular will finds unhampered expression. When political parties go in quest of strange gods we cast them forth into outer darkness, and go on our way rejoicing. It is well that this is so, for so long as this can be done, we may be sure that we are a free people. 

IX

DANIEL WEBSTER

AND THE SENTIMENT OF UNION 



\section{DANIEL WEBSTER}

\section{AND THE SENTIMENT OF UNION}

When the little town of Hampton, on the coast between the Merrimac and Piscataqua rivers, was settled in 1639 by Antinomians who had found cold welcome at Boston, among the company was one Thomas Webster, concerning whom little is known. A hundred years later we find his family living a few miles inland, at Kingston, and there Ebenezer Webster was born in 1739. Late in the Seven Years' War, Ebenezer Webster enlisted in the partisan troop celebrated as Rogers's "Rangers," and after some hard service and wild adventure returned home at the peace of 1763 with the rank of captain. He was soon after married, and with a company of friends and neighbours went to found the town of Salisbury, deep in the wilderness by the upper waters of the Merrimac and in the shadow of Kearsarge Mountain. Captain Webster's log house was built on a hill at the northern end of the township, and between that hill and Montreal, two hundred miles distant, there was nothing but the unbroken pine forest, with its prowling Indians and wolves. In I775 the neighbourhood had become more populous, so that when the stout captain went to join the Continental army he took with him two hundred men. He served in almost every campaign of the Revolutionary War, and rose to the rank of colonel. At Bennington 
he was one of the foremost in storming the German intrenchments; at West Point, on the night of the dreadful day which saw Benedict Arnold's flight to the Vulture, when doubt and misgiving were everywhere, he was placed in command of the guard at headquarters, and Washington said to him, "Colonel Webster, I believe I can trust you." In I 783 this veteran of two wars became owner of the Elms Farm in Salisbury, and lived there until his death, in 1806. He served as representative and senator in the New Hampshire legislature, and as judge in the Court of Common Pleas. In $\mathrm{I} 788$ he was member of the state convention which ratified the federal Constitution. At the first meeting of that convention, which adjourned without a vote, he was bound, like the majority of the delegates, by instructions from his townsmen, to oppose the adoption of the Constitution. Before the second meeting he sought and obtained permission to act according to his own judgment; and when the vote was about to be taken he made the following brief but conclusive speech: " $\mathrm{Mr}$. President, I have listened to the arguments for and against the Constitution. I am convinced such a government as that Constitution will establish, if adopted - a government acting directly on the people of the states - is necessary for the common defence and the common welfare. It is the only government which will enable us to pay off the national debt - the debt which we owe for the Revolution, and which we are bound in honour fully and fairly to discharge. Besides, I have followed the lead of Washington through seven years of war, and I have never been misled. His name is subscribed to this Constitution. $\mathrm{He}$ 
will not mislead us now. I shall vote for its adoption" (Curtis, I. IO).

Colonel Webster was noted for manly beauty and noble bearing, for tireless industry, broad intelligence, and tenacious memory, and for most devoted and selfsacrificing love for his childrer. Of these there were five by the first wife, who died in 1774 ; and five by the second wife, Abigail Eastman, a lady of rare intelligence and strength of character. The youngest son, Daniel, was born on the I8th of January, I 782 , so puny and sickly a babe that it was thought he could not live to grow up. As a lad he was considered too delicate for hard work on the farm, and was accordingly allowed a great deal of time for play. Much of this leisure he spent in fishing and hunting, or in roaming about the woods, the rest in reading. He never could remember when he learned to read. His thirst for knowledge was insatiable; he read every book that came within reach, and conned his favourite authors till he knew them by heart. In May, I796, he was sent to Exeter Academy, where he made rapid progress with his studies, but was so overcome by shyness that he found it impossible to stand up and "speak pieces" before his schoolmates. When he saw so many eyes turned toward him, the words would not come, the master's encouraging remarks only added to his confusion, and he would go away and cry from vexation. But despite this timidity, his natural gifts as an orator had already begun to show themselves. His great, dark, lustrous eyes and rich voice, with its musical inflections, were already exerting fascination upon all who came within their range. Passing teamsters would stop their horses, farmers at work in 
the field would pause, sickle in hand, to hear him recite verses from the Bible, Dr. Watts's hymns, or passages from Addison or Pope. Although Ebenezer Webster found it difficult, by unremitting labour and strictest economy, to support his numerous family, he saw such signs of promise in Daniel as to convince him that it was worth while, at whatever cost, to send him to college. Accordingly, in February, I797, he took him from school, in order to hasten his preparatory studies by the aid of a private tutor, the Rev. Samuel Wood of Boscawen. It was on the sleighride to that town, as they were toiling up a mountainous road through drifted snow, that Colonel Webster informed Daniel of his plans. The sensitive, warmhearted boy, who had hardly dared hope for such good fortune and keenly felt the sacrifice it involved, laid his head upon his father's shoulder and burst into tears. After six months with his tutor, he had learned enough to fulfil the slender requirements of those days for admission to Dartmouth College, where he was duly graduated in r8or. He did not take rank at the head of his class, but it was observed that he was capable of great industry, that he seized an idea with surprising quickness, that his memory was prodigious, and his power of lucid statement unrivalled. Along with these enviable gifts he possessed that supreme poetic quality that defies analysis but is at once recognized as genius. He was naturally, therefore, considered by tutors and fellow-students the most remarkable man in the college, and the position of superiority thus early gained was easily maintained through life and wherever he was placed. While at college he conquered or outgrew his boyish shyness, so as to take 
pleasure in public speaking, and his eloquence soon attracted so much notice that in 1800 the townspeople of Hanover selected this undergraduate to deliver the Fourth of July oration. There he began to preach that love for the Constitution and the Union which was to form his chief theme throughout life. After leaving college he went into a lawyer's office in Salisbury, and began studying law; but he had made up his mind to help his elder brother Ezekiel, of whom he was devotedly fond, to go through college, and this made it necessary for him to earn money by teaching in a country school. In July, I804, he came to Boston in search of employment in some office where he might complete his studies. He was so fortunate as to find favour in the eyes of Christopher Gore, just returned from his mission to England. In Mr. Gore's office, as student and clerk, he could see some of the most eminent men in New England. In 1805 he went to Boscawen, and in two years' time had acquired a good country practice, which he turned over to his brother Ezekiel. He now removed to Portsmouth, where his reputation grew rapidly, so that he was soon considered a worthy antagonist to Jeremiah Mason, one of the greatest lawyers this country has ever produced. In June, I 808, he married Miss Grace Fletcher, of Hopkinton, New Hampshire.

His first important political pamphlet, published that year, was a criticism on the embargo. ${ }^{1}$ In I8 12 ,

${ }^{1}$ In connection with the Embargo that aroused such wide controversy in New England, a correspondent called Dr. Fiske's attention to a jingle that was passed from one to another of the wits of that generation, and was attributed by some to Lucius Manlius Sargent. It ran as follows :-

"Take nothing from nothing and nothing remains; Who votes for the Embargo is a fool for his pains." 
in a speech before the Washington Benevolent Society at Portsmouth, he summarized the objections of the New England people to the war just declared against Great Britain. He was immediately afterward chosen delegate to a convention of the people of Rockingham County, and drew up the so-called "Rockingham Memorial," addressed to President Madison, which contained a formal protest against the war. In the following autumn he was elected to Congress, and on taking his seat, in May, I8I3, he was placed on the Committee on Foreign Relations. His first step in Congress was the introduction of a series of resolutions aimed at the President, and calling for a statement of the time and manner in which Napoleon's pretended revocation of his decrees against American shipping had been announced to the United States. His first great speech, January I4, I8I4, was in opposition to the bill for encouraging enlistments, and at the close of that year he opposed Secretary Monroe's measures for enforcing what was known as the "draft of I8I4." But while Mr. Webster's attitude toward the administration was that of the Federalist party to which he belonged, he did not go so far as the leaders of that party in New England. He condemned the embargo as more harmful to ourselves than to the enemy, as there is no doubt it was; he disapproved the policy of invading Canada, and maintained that our wisest course was to increase the strength of the navy; and on these points history will probably judge him to have been correct. But in his opinion that the war itself was unnecessary and injurious to the country, he was probably, like most New Englanders of that time, mistaken. Could he have foreseen and taken into the 
account the rapid and powerful development of national feeling in the United States which the war called forth, it would have modified his view; for it is clear that the war party, represented by Henry Clay and his friends, was at that moment the truly national party, and $\mathrm{Mr}$. Webster's sympathies were then, as always, in favour of the broadest nationalism, and entirely opposed to every sort of sectional or particularist policy. This broad national spirit, which was strong enough in the two Adamses to sever their connection with the Federalists of New England, led Mr. Webster to use his influence successfully to keep New Hampshire out of the Hartford convention. In the 13 th Congress, however, we find him voting I9I times on the same side with Timothy Pickering, and only 4 times on the opposite side. Other questions were discussed besides those relating to the war. In this and the next Congress the most important work done by Mr. Webster was concerned with the questions of currency and a national bank. He did good service in killing the pernicious scheme for a bank endowed with the power of issuing irredeemable notes and obliged to lend money to the government. He was even disposed to condemn outright the policy of allowing the government to take any part whatever in the management of the bank. He also opposed a protective tariff, but by supporting Mr. Calhoun's bill for internal improvements he put himself on record as a loose constructionist. In the light of subsequent events it seems odd to find Mr. Calhoun defending the policy of internal improvements on the ground of its tendency to consolidate the Union, and it seems odd to find Mr. Webster in cordial alliance with the great South 
Carolinian upon this or any other question. But it is to be borne in mind that, owing to the concessions made to slavery in the federal Constitution, South Carolina was at first strongly Federalist in her politics, and but for her attitude in this regard it is not at all likely that the Constitution would ever have been ratified. It was the prompt action of South Carolina in 1788 that killed the promising scheme of the Antifederalists of Virginia, headed by Patrick Henry, for a separate Southern confederacy. It was not until after I 820 that South Carolina started upon the opposite course, which in less than ten years was to carry her to the verge of secession. It was the strength of the Northern opposition to the admission of Missouri as a slave state that first alarmed South Carolina; and her political alliance with New England was broken when the latter section of the country began to declare itself in favour of high tariffs. But in 1816 it was quite natural that, on a question concerning the general powers of the federal government, Mr. Calhoun and Mr. Webster should be found on the same side. In the course of this session of Congress the cantankerous Randolph saw fit to defy Mr. Webster to mortal combat for words spoken in debate; but the challenge was declined with grim humour. Mr. Webster said that he did not feel called upon to expose his life at the request of any other man who might be willing to risk his own; but he should always "be prepared to repel in a suitable manner the aggression of any man" who should venture to "presume upon such a refusal." Mr. Randolph had thus no alternative but to ignore this very significant hint, and gracefully declare his nice sense of honour quite satisfied. 
At the expiration of his second term in Congress, Mr. Webster retired for a while to private life. $\mathrm{He}$ was in great need of money, and, moving from Portsmouth to Boston about this time, he soon found himself earning in his profession not less than $\$ 20,000$ a year. One of the first cases upon which he was now engaged was the famous Dartmouth College affair. While Mr. Webster's management of this case went far toward placing him at the head of the American bar, the political significance of its decision was such as to make it an important event in the history of the United States. It shows Mr. Webster not only as a great constitutional lawyer and consummate advocate, but also as a powerful champion of federalism. In its origin Dartmouth College was a missionary school for Indians, founded in 1754 by the Rev. Eleazar Wheelock, at Lebanon, Connecticut. After a few years, funds were raised by private subscription for the purpose of enlarging the school into a college, and as the Earl of Dartmouth had been one of the chief contributors, Dr. Wheelock appointed him and other persons trustees of the property. The site of the college was fixed in New Hampshire, and a royal charter in 1769 created it a perpetual corporation. The charter recognized Wheelock as founder, and appointed him president, with power to name his successor, subject to confirmation by the trustees. Dr. Wheelock devised the presidency to his son John Wheelock, who accordingly became his successor. The charter, in expressly forbidding the exclusion of any person on account of his religious belief, reflected the broad and tolerant disposition of Dr. Wheelock, who was a liberal Presbyterian, and as such had been 
engaged in prolonged controversy with that famous representative of the strictest Congregationalism, Dr. Joseph Bellamy. In I 793, Bellamy's pupil, Nathaniel Niles, became a trustee of Dartmouth, and between him and John Wheelock the old controversy was revived and kept up with increasing bitterness for several years, dividing the board of trustees into two hostile parties. At length, in 1809, the party opposed to President Wheelock gained a majority in the board, and thus became enabled in various ways to balk and harass the president, until in 1815 the quarrel broke forth into a war of pamphlets and editorial articles that convulsed the whole state of New Hampshire. The Congregational Church was at that time the established church in New Hampshire, supported by taxation, and the Federalist party found its strongest adherents among the members of that church. Naturally, therefore, the members of other churches, and persons opposed on general principles to the establishment of a state church, were inclined to take sides with the Republicans. In 18 I5 President Wheelock petitioned the legislature for a committee to investigate the conduct of the trustees, whom he accused of various offences, from intolerance in matters of religion to improper management of the funds. Thus the affair soon became a party question, in which the Federalists upheld the trustees, while the Republicans sympathized with the president. The legislature granted the petition for a committee, but the trustees forthwith, in a somewhat too rash spirit of defiance, deposed Mr. Wheelock and chose a new president, the Rev. Francis Brown. In the ensuing state election Mr. Wheelock and his sympathizers 
went over to the Republicans, who thus succeeded in electing their candidate for governor, with a majority of the legislature. In June, I816, the new legislature passed an act reorganizing the college, and a new board of trustees was at once appointed by the governor. Judge Woodward, secretary of the old board, went over to the new board and became its secretary, taking with him the college seal. The new board proceeded to expel the old board, which forthwith brought suit against Judge Woodward in an action of trover for the college seal. The case was tried in May, 1817 , with those two great lawyers, Jeremiah Mason and Jeremiah Smith, as counsel for the plaintiffs. It was then postponed till September, when Mr. Webster was secured by the plaintiffs as an additional counsel. The plaintiffs contended that in the case of a corporation chartered for private uses, any alleged misconduct of the trustees was properly a question for the courts, and not for the legislature, which in meddling with such a question plainly transcended its powers. Their chief reliance was upon this point, but they contended that the act of legislature reorganizing the college was an act impairing the obligation of a contract, and therefore violated the Constitution of the United States. Nothing is more interesting or more significant in the history of the case than the fact that neither of the three great lawyers who represented the plaintiffs at first attached much importance to this second point, which to-day seems so obvious that we only wonder how any one could ever for a moment have hesitated about urging it. One could hardly find anywhere a more forcible illustration of the change which seventy years have wrought in our 
conception of the sphere and duties of the federal government; and one of the most potent factors in that change was the decision of the Supreme Court in this very case of Dartmouth College. The state court at Exeter decided against the plaintiffs, and the decision would have been final had it not been for the point which at first they had approached so gingerly, but which now enabled them to carry up their case to the Supreme Court of the United States.

It now remained to be seen whether the federal tribunal would admit the position of the plaintiffs, or dismiss the case for want of jurisdiction. As the elder counsel were unable to go to Washington, it fell to Mr. Webster to conduct the case, which was tried in March, I8I8. He argued that the charter of Dartmouth College created a private corporation for administering a charity; that in the administration of such uses the trustees have a recognized right of property; that the grant of such a charter is a contract between the sovereign power and the grantees, and descends to their successors, and that therefore the act of the New Hampshire legislature, in taking away the government from one board of trustees and conferring it upon another, was a violation of contract, and as such an infringement of the federal Constitution. These legal points were argued by Mr. Webster with masterful cogency, and reënforced by illustrations and allusions well calculated to appeal to the Federalist sympathies of Chief Justice Marshall. For, besides the legal interpretation, there was an important political side to the question which recommended it to the earnest consideration of the great judge, who, in building up a new system of federal 
jurisprudence in accordance with the spirit of English precedents, was often to some extent obliged to make law as well as declare it. Should the legislative action of a state upon its own citizens be final, so that there should be no secure shelter for vested rights against the unchecked caprice of a mere majority swayed by some momentary impulse; or was the authority of the federal government competent to insure that the state, in dealing with individuals or with private corporations, should recognize certain fundamental principles of law as sacred and unassailable? The latter alternative was, of course, the one for which our federal Constitution was designed to provide, but incalculable consequences depended upon the extent of jurisdiction which, in accordance with that instrument, might be claimed by the federal courts. Here was a question that touched the master chord in the natures alike of the mighty advocate and of the mighty judge, and as the one spoke and the other listened, it must have been, indeed, a memorable scene. Mr. Webster possessed in the highest degree the art of so presenting a case that the mere statement seemed equivalent to demonstration; and never perhaps did he exhibit that art in greater perfection or use it to better purpose than in this argument, in which the political aspect of the case was plainly seen and felt, but never allowed to intrude upon the foreground, where the purely legal considerations were mustered. The concluding sentences have often been remarked as bold and consummate in their art, in suddenly abandoning argument and appealing to emotion. But the art in it was doubtless that best kind of art that nature makes. Mr. Webster was a man of intense 
feelings. He was not merely defending a great principle of constitutional government, but he was pleading the cause of the little college where, by dint of hard work and many sacrifices, his brother Ezekiel and himself had obtained their education. Instead of describing in general terms what would happen if American colleges were liable to be drawn into the political arena and their government made the sport of contending parties, he closed his speech with these few simple words: "This, sir, is my case. It is the case not merely of that humble institution, it is the case of every college in our land. . . . Sir, you may destroy this little institution; it is weak, it is in your hands! I know it is one of the lesser lights in the literary horizon of our country. You may put it out. But if you do so, you must carry through your work! You must extinguish one after another those greater lights of science which for more than a century have thrown their radiance over our land. It is, sir, as I have said, a small college. And yet, there are those who love it." Here Mr. Webster's voice trembled and his eyes were wet with tears. Coming from this grand and stately man, who for five hours had held judges and audience spellbound by power of reasoning and beauty of phrase, the effect of this natural burst of feeling was extraordinary. Leaning forward in breathless silence, with eyes suffused and with beating hearts, judges and audience forgot all else in eager watching of every movement of the speaker's face, when recovering himself he said in his most solemn tones, addressing the chief justice: "Sir, I know not how others may feel [glancing at the opponents of the college before him], but for myself, when I see my Alma Mater sur- 
rounded, like Cæsar in the senate-house, by those who are reiterating stab after stab, I would not for this right hand have her turn to me and say, Et tu quoque, mi fili! And thou too, my son!" As he sat down, said a gentleman who was present, "there was a deathlike stillness throughout the room for some moments; every one seemed to be slowly recovering himself, and coming gradually back to his ordinary range of thought and feeling." The decision of the court, rendered in the following autumn, sustained Mr. Webster and set aside the act of the legislature as unconstitutional. It was one of those far-reaching decisions in which the Supreme Court, under Marshall, fixed the interpretation of the Constitution in such wise as to add greatly to its potency as a fundamental instrument of government. It was a case in which a contrary decision would have altered the whole future of American law, and would have modified our political and social development in many ways. The clause of our Constitution prohibiting state legislation in impairment of contracts, like most such general provisions, stood in need of judicial decisions to determine its scope. By bringing under the protection of this clause every charter granted by a state, the decision in the Dartmouth College case went farther perhaps than any other in our history toward limiting state sovereignty and extending the federal jurisdiction.

This extension of federal power was, moreover, entirely in the right direction. It was conservative, pacific, and just in its tendencies. It is no part of the legitimate business of government to help people in business, whether under pretence of fostering domestic industry, or what not; but it is the legitimate business 
of government to preserve order and punish criminals, to see that contracts are fulfilled, that charters are kept inviolate, and the foundations of human confidence not rudely or wantonly disturbed, for only thus does the community insure for its members a fair field and no favour.

In the Dartmouth College case we may see one chapter in Mr. Webster's great life-work of strengthening the federal government and tightening the bonds of pacific union among the states.

In the Massachusetts convention of 1820 for revising the state constitution, he next played an important part. He advocated with success the abolition of religious tests for office-holders, and in a speech in support of the feature of property representation in the senate he examined the theory and practice of bicameral legislation. His discussion of that subject is well worthy of study. In the same year, at the celebration of the second centennial of the landing of the Pilgrims, his commemorative oration was one of the noblest ever delivered. In 1825, on the laying of the corner-stone of Bunker Hill monument, he attained still higher perfection of eloquence; and one year later, on the deaths of Adams and Jefferson, his eulogy upon those statesmen completed a trio of historical addresses unsurpassed in splendour. The spirit which animates these orations is that of the broadest patriotism, enlightened by a clear perception of the fundamental importance of the federal union between the states, and an ever present consciousness of the mighty future of our country and its moral significance in the history of the world. Such topics have often been treated as commonplaces, and made the theme of vapid rhetoric; but under Daniel 
Webster's treatment they acquired a philosophical value, and were fraught with most serious and earnest meaning. These orations were conceived in a spirit of religious devotion to the Union, and contributed powerfully toward awakening such a sentiment in those who read them afterward, while upon those who heard them from the lips of the majestic speaker the impression was such as could never be effaced. The historian must assign to them a high place among the literary influences that aroused in the American people a sentiment of union strong enough to endure the shock of war.

In $1822 \mathrm{Mr}$. Webster was elected to Congress from the Boston district, and was twice reëlected by a popular vote that was almost unanimous. As chairman of the Judiciary Committee of the House, he prepared and carried the "crimes act," in which the criminal jurisprudence of the federal courts was thoroughly remodelled. The preparation of this bill showed in a high degree his constructive genius as a legislator, while in carrying it through Congress his parliamentary skill and persuasiveness in debate were equally conspicuous. Of his two most celebrated speeches in Congress during this period, the first related to the revolution in Greece. In January, I 824, Mr. Webster brought forward a resolution in favour of making provision for a commissioner to Greece, should President Monroe see fit to appoint one. In his speech on this occasion, he set forth the hostility of the American people to the principles, motives, and methods of the Holy Alliance, and their sympathy with such struggles for self-government as that in which the Greeks were engaged. The resolution was not adopted, but the 
speech gave its author a European reputation. It was translated into almost all the languages of Europe, from Gibraltar to the Volga, and called forth much lively comment.

The other great speech, delivered in April, I824; was what is commonly called Mr. Webster's "free trade speech." A bill had been introduced for revising the tariff in such a way as to extend the operation of the protective system. In this speech Mr. Webster found fault with the phrase "American policy," as applied by Mr. Clay to the system of high protective duties. "If names are thought necessary," said Mr. Webster, "it would be well enough, one would think, that the name should be in some measure descriptive of the thing; and since Mr. Speaker denominates the policy which he recommends a 'new policy in this country'; since he speaks of the present measure as a new era in our legislation; since he professes to invite us to depart from our accustomed course, to instruct ourselves by the wisdom of others, and to adopt the policy of the most distinguished foreign states, - one is a little curious to know with what propriety of speech this imitation of other nations is denominated an 'American policy,' while, on the contrary, a preference for our own established system, as it now actually exists and always has existed, is called a 'foreign policy.' This favourite American policy is what America has never tried; and this odious foreign policy is what, as we are told, foreign states have never pursued. Sir, that is the truest American policy which shall most usefully employ American capital and American labbour." After this exordium, Mr. Webster went on to give a masterly exposition of some of 
the elementary theorems of political economy, and a survey, at once comprehensive and accurate, of the condition of American industry at the time. He not only attacked Mr. Clay's policy on broad national grounds, but also showed more specifically that it was likely to prove injurious to the maritime commerce in which the New England states had so long taken the lead; and he concluded by characterizing that policy as "so burdensome and so dangerous to that interest which has steadily enriched, gallantly defended, and proudly distinguished us, that nothing can prevail upon me to give it my support." Upon this last clause of his speech he was afterward enabled to rest a partial justification of his change of attitude toward the tariff.

In politics Mr. Webster occupied at this time quite an independent position. The old Federalist party, to which he had formerly belonged, was completely broken down, and the new National Republican party, with its inheritance of many of the principles, motives, and methods of the federalists, was just beginning to take shape under the leadership of Adams and Clay. Between these eminent statesmen and Mr. Webster, the state of feeling was not such as to insure cordial coöperation; but in their views of government there was similarity enough to bring them together in opposition to the new Democratic party represented by Jackson, Benton, and Van Buren. With the extreme Southern views of Crawford and Calhoun it was impossible that he should sympathize, although his personal relations with those leaders were quite friendly, and after the death of Calhoun the noblest eulogium upon his character and motives was made by $\mathrm{Mr}$. Webster. Coleridge once said that every man is born 
either an Aristotelian or a Platonist. There is a sense in which all American statesmen may be said to be intellectually the descendants and disciples, either of Jefferson or of Hamilton, and as a representative follower of Hamilton, Mr. Webster was sure to be drawn rather toward Clay than toward Jackson. The course of industrial events in New England was such as to involve changes of opinion in that part of the country, which were soon reflected in a complete reversal of $\mathrm{Mr}$. Webster's attitude toward the tariff. In 1827 he was elected to the United States Senate. In that year an agitation was begun by the woollen manufacturers, which soon developed into a promiscuous scramble among different industries for aid from government, and finally resulted in the tariff of 1828 . That act, which was generally known at the time as "the tariff of abominations," was the first extreme application of the protective system in our federal legislation. When the bill was pending before the Senate in April, I828, Mr. Webster made a memorable speech, in which he completely abandoned the position he had held in 1824 , and from this time forth he was a supporter of the policy of Mr. Clay and the protectionists. For this change of attitude he was naturally praised by his new allies, who were glad to interpret it as a powerful argument in favour of their views. By every one else he was blamed, and this speech has often been cited, together with that of March 7, I850, as proving that Mr. Webster was governed by unworthy motives and wanting in political principle. The two cases, as we shall see, are in many respects parallel. In neither case did Mr. Webster attempt to conceal or disguise his real motives. In 1828 he frankly admitted that the policy 
of protection to manufacturers, by means of tariff duties, was a policy of which he had disapproved, whether as a political economist or as a representative of the interests of New England. Against his own opposition and that of New England the act of I 824 had passed. "What, then, was New England to do?. . . Was she to hold out forever against the course of the government, and see herself losing on one side and yet make no effort to sustain herself on the other? No, sir. Nothing was left for New England but to conform herself to the will of others. Nothing was left to her but to consider that the government had fixed and determined its own policy; and that policy was protection." In other words, the tariff policy adopted at Washington, while threatening the commercial interests of New England, had favoured the investment of capital in manufactures there, and it was not becoming in a representative of New England to take part in disturbing the new arrangement of things. This argument, if pushed far enough, would end in the doctrine - now apparently obsolete, though it has often been attacked and defended - that a senator is simply the ambassador of his state in Congress. With Mr. Webster it went so far as to modify essentially his expressions of opinion as to the constitutionality of protective legislation. He had formerly been inclined to interpret the Constitution strictly upon this point, but in 1828 and afterward his position was that of the loose constructionists. From the economic point of view he would doubtless have been a safer guide for New England had he insisted upon acting up to the full measure of his convictions. He was too honest a thinker to be able to conceal the real workings of his mind, 
and his speeches in defence of the high tariff policy never once had the ring of true metal. Other men might be fooled by the sophistry of protectionism, but he was not. It would be unfair, however, to charge him with conscious dereliction to principle in this matter. It would be more just and more correct to say that, amid the complication of conflicting interests, he felt it necessary to subordinate one question to another that was at that time clearly more important. His conduct was far more the result of his strong Federalist bias than of the temperament which has sometimes been called "opportunism."

This tariff of 1828 soon furnished an occasion for the display of his strong Federalist spirit in a way that was most serviceable for his country and has earned for him undying fame as an orator and statesman. It led to the distinct announcement of the principles of nullification by the public men of South Carolina, with Mr. Calhoun at their head. During President Jackson's first term the question as to nullification seemed to occupy everybody's thoughts, and had a way of intruding upon the discussion of all other questions. In December, 1829, Samuel A. Foote of Connecticut presented to the Senate a resolution inquiring into the expediency of limiting the sales of the public lands to those already in the market, besides suspending the surveys of the public lands and abolishing the office of Surveyor-general. The resolution was quite naturally resented by the Western senators, as having a tendency to check the growth of their section of the country. The debate was opened by Mr. Benton, and lasted several weeks, with increasing bitterness. The belief in the hostility of the New England states toward 
the West was shared by many Southern senators, who desired to unite South and West in opposition to the tariff. On the I 9 th of January, I 830, Robert Y. Hayne of South Carolina attacked the New England states, accusing them of aiming by their protective policy at aggrandizing themselves at the expense of all the rest of the Union. On the next day Mr. Webster delivered his "first speech on Foote's resolution," in which he took up Mr. Hayne's accusations and answered them with great power. This retort provoked a long and able reply from Mr. Hayne, in which he not only assailed Mr. Webster and Massachusetts and New England, but set forth quite ingeniously and elaborately the doctrines of nullification. In view of the political agitation then going on in South Carolina, it was felt that this speech would work practical mischief unless it should meet with instant refutation. It was finished on the $25^{\text {th }}$ of January, and on the next two days Mr. Webster delivered his "second speech on Foote's resolution," better known in history as the "Reply to Hayne." The debate had now lasted so long that people had come from different parts of the country to Washington to hear it, and on the 26th of January the crowd not only filled the galleries and invaded the floor of the senate-chamber, but occupied all the lobbies and entries within hearing and even beyond. In the first part of his speech Mr. Webster replied to the aspersions upon himself and New England; in the second part he attacked with weighty argument and keen-edged sarcasm the doctrine of nullification. He did not undertake to deny the right of revolution, as a last resort in cases with which legal and constitutional methods are found inadequate to 
deal; but he assailed the theory of the Constitution maintained by Calhoun and his followers, according to which nullification was a right the exercise of which was compatible with loyal adherence to the Constitution. His course of argument was twofold: he sought to show, first, that the theory of the Constitution as a terminable league or compact between sovereign states was unsupported by the history of its origin, and secondly, that the attempt, on the part of any state, to act upon that theory must necessarily entail civil war or the disruption of the Union. As to the sufficiency of his historical argument, there has been much difference of opinion. The question is difficult to deal with in such a way as to reach an unassailable conclusion, and the difficulty is largely due to the fact that in the various ratifying conventions of $1787-1789$ the men who advocated the adoption of the Constitution did not all hold the same opinions as to the significance of what they were doing. There was great divergence of opinion, and plenty of room for antagonisms of interpretation to grow up as irreconcilable as those of Webster and Calhoun. If the South Carolina doctrine distorted history in one direction, that of Mr. Webster certainly departed somewhat from the record in the other; but the latter was fully in harmony with the actual course of our national development and with the increased and increasing strength of the sentiment of union at the time when it was propounded with such powerful reasoning and such magnificent eloquence in the "Reply to Hayne." As an appeal to the common sense of the American people, nothing could be more masterly than Mr. Webster's demonstration that nullification practically meant revolution; 
and their unalterable opinion of the soundness of his argument was amply illustrated when at length the crisis came, which he deprecated with such intensity of emotion in his concluding sentences. To some of the senators who listened to the speech, as for instance Thomas H. Benton, it seemed as if the passionate eloquence of its close concerned itself with imaginary dangers never likely to be realized; but the event showed that Mr. Webster estimated correctly the perilousness of the doctrine against which he was contending. For genuine oratorical power, the "Reply to Hayne" is probably the greatest speech that has been delivered since the oration of Demosthenes on the crown. The comparison is natural, as there are points in the American orator that forcibly remind one of the Athenian. There is the fine sense of proportion and fitness, the massive weight of argument due to transparent clearness and matchless symmetry of statement, and along with the rest a truly Attic simplicity of diction. Mr. Webster never indulged in mere rhetorical flights; his sentences, simple in structure and weighted with meaning, went straight to the mark; and his arguments were so skilfully framed that, while his most learned and critical hearers were impressed with a sense of their conclusiveness, no man of ordinary intelligence could fail to understand them. To these high qualifications of the orator was added such a physical presence as but few men have been endowed with. I believe it was Carlyle who said of him, "I wonder if any man can possibly be as great as he looks!" 1 Mr. Webster's appearance was indeed

${ }^{1}$ In his paper on Andrew Jackson and American Democracy, page 270 of this volume, Dr. Fiske refers to the bright blue coat with brass buttons and buff waistcoat as worn by Daniel Webster, which came to be a symbol of Americanism. In 
one of unequalled dignity and power, his voice was rich and musical, and the impressiveness of his delivery was enhanced by the depth of genuine manly feeling with which he spoke. Yet while his great speeches owed so much of their overpowering effect to the look and manner of the man, they were at the same time masterpieces of literature. Like the speeches of Demosthenes, they were capable of swaying the reader as well as the hearer, and their effects went far beyond the audience and far beyond the occasion of their delivery.

In all these respects the "Reply to Hayne" marks the culmination of Mr. Webster's power as an orator. Of all the occasions of his life, this encounter with the

discussing " the provincialism of ante bellum days," the late Mr. Justin Winsor wrote Dr. Fiske, February 3, 1892, as follows: ". . . the blue coat and brass buttons, which so grandly set off the figure of Webster - I remember him in them often. He wore them when he made that speech at Marshfield, in which he showed his bitter disappointment that the Whigs had not nominated him rather than Taylor, and I was close to him during the whole of it. But I never supposed that it was solely because it gave brilliancy to a dignified carriage that be clung to that costume; but rather because it showed the Whig colours of blue and yellow, which Fox and his fellows had made common in precisely the same way in England during the early years of the century; and indeed I think George IV. when Regent wore it, when not in state. Certainly it was not an uncommon dress in Europe at a later period. When I was there in the early fifties, I had a dress coat of blue, with brass buttons, made in Paris, and I was not by any means singular in wearing it in company in Paris and Heidelberg."

A note on Dr. Boott, "Life and Letters of Charles Darwin," 2d edition, page 294, throws further light on this point: "Francis Boott (born 1792, died 1863) ... was . . . well known in connection with the Linnæean Society. ... He is described (in a biographical sketch published in the Gardener's Chronicle, 1864) as having been one of the first physicians in London who gave up the customary black coat, knee breeches, and silk stockings, and adopted the ordinary dress of the period, a blue coat with brass buttons and a buff waistcoat, a costume which he continued to wear to the last."

Though the blue-tailed coat was indeed an ordinary gentleman's costume in England, it stood, as may be seen from coloured prints of the day, rather for quiet and dignity than for "smartness" and fashion. In the United States it certainly developed independently into what Daniel Webster made it - a symbol of Americanism. 
doctrine of nullification on its first bold announcement in the Senate was certainly the greatest; and the speech was equal to the occasion. It struck a chord in the heart of the American people which had not ceased to vibrate when the crisis came thirty years later. It gave articulate expression to a sentiment of loyalty to the Union that went on growing until the American citizen was as prompt to fight for the Union as the Mussulman for his Prophet or the Cavalier for his king. It furnished, moreover, a clear and comprehensive statement of the theory by which that sentiment of loyalty was justified. Of the men who in after years gave up their lives for the Union, doubtless the greater number had as schoolboys declaimed passages from this immortal speech and caught some inspiration from its fervid patriotism. Probably no other speech ever made in Congress has found so many readers or exerted so much influence in giving shape to men's thoughts.

Three years afterward Mr. Webster returned to the struggle with nullification, being now pitted against the master of that doctrine instead of the disciple. In the interval South Carolina had attempted to put the doctrine into practice, and had been resolutely met by President Jackson with his proclamation of the Ioth of December, I832. In response to a special message from the President, early in January, I833, the so-called "force bill," empowering the President to use the army and navy, if necessary, for enforcing the revenue laws in South Carolina, was reported in the Senate. The bill was opposed by Democrats who did not go so far as to approve of nullification, but the defection of these senators was 
more than balanced by the accession of Mr. Webster, who upon this measure came promptly to the support of the administration. For this, says Benton, "his motives ... were attacked, and he was accused of subserviency to the President for the sake of future favour. At the same time, all the support which he gave to these measures was the regular result of the principles which he laid down against nullification in the debate with Mr. Hayne, and he could not have done less without being derelict to his own principles then avowed. It was a proud era in his life, supporting with transcendent ability the cause of the Constitution and of the country, in the person of a chief magistrate to whom he was politically opposed, bursting the bonds of party at the call of duty, and displaying a patriotism worthy of admiration and imitation. General Jackson felt the debt of gratitude and admiration which he owed him; the country, without distinction of party, felt the same. . . . He was the colossal figure on the political stage during that eventful time; and his labours, splendid in their day, survive for the benefit of distant posterity" ("Thirty Years' View," I. 334). The support of the President's policy by Mr. Webster, and its enthusiastic approval by nearly all the Northern and a great many of the Southern people, seems to have alarmed Mr. Calhoun, probably not so much for his personal safety as for the welfare of his nullification schemes. The story that he was frightened by the rumour that Jackson had threatened to begin by arresting him on a charge of treason is now generally discredited. He had seen enough, however, to convince him that the theory of peaceful nullification was not now likely to be realized. It 
was not his aim to provoke an armed collision, and accordingly a momentary alliance was made between himself and Mr. Clay, resulting in the compromise tariff bill of the I2th of February, 1833. Only four days elapsed between Mr. Webster's announcement of his intention to support the President and the introduction of this compromise measure. Mr. Webster at once opposed the compromise, both as unsound economically and as an unwise and dangerous concession to the threats of the nullifiers. At this point the force bill was brought forward, and Mr. Calhoun made his great speech, February 15 and 16 , in support of the resolutions he had introduced on the $22 \mathrm{~d}$ of January, affirming the doctrine of nullification. To this Mr. Webster replied, February 16, with his speech entitled "The Constitution not a Compact between Sovereign States," in which he supplemented and reënforced the argument of the "Reply to Hayne." Mr. Calhoun's answer, February 26, was perhaps the most powerful speech he ever delivered, and Mr. Webster did not reply to it at length. The burden of the discussion was, what the American people really did when they adopted the federal Constitution. Did they simply create a league between sovereign states, or did they create a national government, which operates immediately upon individuals, and, without superseding the state governments, stands superior to them and claims a prior allegiance from all citizens? It is now plain to be seen that in point of fact they did create such a national government; but how far they realized at the outset what they were doing is quite another question. Mr. Webster's main conclusion was sustained with colossal strength; but 
his historical argument was in some places weak, and the weakness is unconsciously betrayed in a disposition toward wire-drawn subtlety, from which $\mathrm{Mr}$. Webster was usually quite free. His ingenious reasoning upon the meaning of such words as "compact" and "accede" was easily demolished by Mr. Calhoun, who was, however, more successful in hitting upon his adversary's vulnerable points than in making good his own case. In fact, the historical question was not really so simple as it presented itself to the minds of those two great statesmen. But in whatever way it was to be settled, the force of Mr. Webster's practical conclusions remained, as he declared in the brief rejoinder with which he ended the discussion, - " $\mathrm{Mr}$. President, turn this question over and present it as we will-argue it as we may-exhaust upon it all the fountains of metaphysics - stretch over it all the meshes of logical or political subtlety - it still comes to this, Shall we have a general government? Shall we continue the union of the states under a government instead of a league? This is the upshot of the whole matter; because, if we are to have a government, that government must act like other governments, by majorities; it must have this power, like other governments, of enforcing its own laws and its own decisions; clothed with authority by the people and always responsible to the people, it must be able to hold its course unchecked by external interposition: According to the gentleman's views of the matter, the Constitution is a league; according to mine, it is a regular popular government. This vital and all-important question the people will decide, and in deciding it they will determine whether, by ratifying the pres- 
ent Constitution and Frame of Government, they meant to do nothing more than to amend the articles of the old confederation." As the immediate result of the debates, both the force bill and the compromise tariff bill were adopted, and this enabled Mr. Calhoun to maintain that the useful and conservative character of nullification had been demonstrated, since the action of South Carolina had, without leading to violence, led to such modifications of the tariff as she desired. But the abiding result was, that $\mathrm{Mr}$. Webster had set forth the theory upon which the Union was to be preserved, and that the administration, in acting upon that theory, had established a precedent for the next administration that should be called upon to confront a similar crisis.

The alliance between Mr. Webster and President Jackson extended only to the question of maintaining the Union. As an advocate of the policy of a national bank, a protective tariff, and internal improvements, Mr. Webster's natural place was by the side of $\mathrm{Mr}$. Clay in the Whig party, which was now in the process of formation. He was also at one with both the Northern and the Southern sections of the Whig party in opposition to what Mr. Benton called the "demos krateo" principle, according to which the President, in order to carry out the "will of the people," might feel himself authorized to override the constitutional limitations upon his power. This was not precisely what Mr. Benton meant by his principle, but it was the way in which it was practically illustrated in Jackson's war against the bank. In the course of this struggle, Mr. Webster made more than sixty speeches, remarkable for their wide and accurate knowledge of 
finance. His consummate mastery of statement is nowhere more thoroughly exemplified than in these speeches. Constitutional questions were brought up by Mr. Clay's resolutions censuring the President for the removal of the deposits and for dismissing William J. Duane, Secretary of the Treasury. In reply to the resolutions, President Jackson sent to the Senate his remarkable "Protest," in which he maintained that in the mere discussion of such resolutions that body transcended its constitutional prerogatives, and that the President is the "direct representative of the American people," charged with the duty, if need be, of protecting them against the usurpations of Congress. The Whigs maintained, with much truth, that this doctrine, if carried out in all its implications, would push democracy to the point where it merges in Cæsarism. It was now that the opposition began to call themselves Whigs, and tried unsuccessfully to stigmatize the President's supporters as "Tories." Mr. Webster's speech on the President's protest, May 7, I834, was one of great importance, and should be read by every student of our constitutional history. In another elaborate speech, February 16, I835, he tried to show that under a proper interpretation of the Constitution the power of removal, like the power of appointment, was vested in the President and Senate conjointly, and that "the decision of Congress in I789, which separated the power of removal from the power of appointment, was founded on an erroneous construction of the Constitution." But subsequent opinion has upheld the decision of 1789 , leaving the speech to serve as an illustration of the way in which, under the stress of a particular contest, the Whigs 
were as ready to strain the Constitution in one direction as the Democrats were inclined to bend it in another. An instance of the latter kind was Mr. Benton's expunging resolution, against which Mr. Webster emphatically protested.

About this time Mr. Webster was entertaining thoughts of retiring, for a while at least, from public life. As he said in a letter to a friend, he had not for fourteen years had leisure to attend to his private affairs or to become acquainted by travel with his own country. This period had not, however, been entirely free from professional work. It was seldom that Mr. Webster took part in criminal trials, but in this department of legal practice he showed himself qualified to take rank with the greatest advocates that have ever addressed a jury. His speech for the prosecution, on the trial of the murderers of Captain Joseph White, at Salem, in August, 1830, has been pronounced equal to the finest speeches of Lord Erskine. In the autumn of $\mathrm{I} 824$, while driving in a chaise with his wife from Sandwich to Boston, he stopped at the beautiful farm of Captain John Thomas, by the seashore at Marshfield. For the next seven years his family passed their summers at this place as guests of Captain Thomas; and as the latter was growing old and willing to be eased of the care of the farm, Mr. Webster bought it of him in the autumn of $183 \mathrm{I}$. Captain Thomas continued to live there, until his death in 1837 , as Mr. Webster's guest. For the latter it became the favourite home whither he retired in the intervals of public life. It was a place, he said, where he "could go out every day in the year and see something new." Mr. Webster was very fond of the sea. 
He had also a passion for country life, for all the sights and sounds of the farm, for the raising of fine animals, as well as for hunting and fishing. The earlier years of Mr. Webster's residence at Marshfield, and of his service in the United States Senate, witnessed some serious events in his domestic life. Death removed his wife, January 21, I828, and his brother Ezekiel, April I0, 1829. In December, 1829, he married Miss Caroline Le Roy, daughter of a wealthy merchant in New York. Immediately after this second marriage came the "Reply to Hayne." The beginning of a new era in his private life coincided with the beginning of a new era in his career as a statesman. After I $830 \mathrm{Mr}$. Webster was recognized as one of the greatest powers in the nation, and it seemed natural that the presidency should be offered to such a man. His talents, however, were not those of a party leader. He was always too independent. The earliest election at which he could have been a candidate for the presidency was that of $1_{132}$, and then there could be no doubt that Mr. Clay represented much more completely than Mr. Webster the doctrines of paternal government opposed by President Jackson. In the helter-skelter scramble of 1836 the legislature of Massachusetts nominated Mr. Webster, and he received the electoral vote of that state alone. The newly formed Whig party was inclined to withhold its true leaders and put forward a western soldier, General Harrison, in the hope of turning to their own uses the same kind of unreflecting popular enthusiasm which had carried General Jackson to the White House. In this policy, aided by the commercial distress which began in 1837 , they succeeded in 1840 . 
Mr. Webster then accepted the office of Secretary of State in the Harrison-Tyler administration, and soon showed himself as able in diplomacy as in other departments of statesmanship. A complication of diffculties with Great Britain seemed to be bringing us to the verge of war. There was the long-standing dispute about the northeastern boundary, which had not been adequately defined by the treaty of 1783 , and along with the renewal of this controversy there came up the cases of McLeod and the steamer Caroline, the slave-ship Creole, and all the manifold complications which these cases involved. The Oregon question, too, was looming in the background. In disentangling these difficulties, Mr. Webster showed rare tact and discretion. He was fortunately helped by the change of ministry in England, which transferred the management of foreign affairs from the hands of Lord Palmerston to those of Lord Aberdeen. Edward Everett was then in London, and Mr. Webster secured his appointment as minister to Great Britain. In response to this appointment, Lord Ashburton, whose friendly feeling toward the United States was known to every one, was sent over on a special mission to confer with Mr. Webster; and the result was the Ashburton treaty of 1842 , by which an arbitrary and conventional line was adopted for the northeastern boundary, while the loss thereby suffered by the states of Maine and Massachusetts was to be indemnified by the United States. It was also agreed that Great Britain and the United States should each keep its own squadron to watch the coast of Africa for the suppression of the slave-trade, and that in this good work each nation should separately enforce its own 
laws. This clause of the treaty was known as the "cruising convention." The old grievance of the impressment of seamen, which had been practically abolished by the glorious victories of American frigates in the War of I8I2-I8I5, was now formally ended by Mr. Webster's declaration to Lord Ashburton that henceforth American vessels would not submit themselves to be searched. Henceforth the enforcement of the so-called "right of search" by a British ship would be regarded by the United States as a casus belli. When all the circumstances are considered, this Ashburton treaty shows that Mr. Webster's powers as a diplomatist were of a high order. In the hands of an ordinary statesman, the affair might easily have ended in a war; but his management was so dexterous that, as we now look back upon the negotiation, we find it hard to realize that there was any real danger. Perhaps there could be no more conclusive proof, or more satisfactory measure, of his success.

While these important negotiations were going on, great changes had come over the political horizon. There had been a quarrel between the Northern and Southern sections of the Whig party, and on the I Ith of September, I84I, all the members of President $\mathrm{T}_{\mathrm{Y}}$ ler's cabinet, except Mr. Webster, resigned. It seems to have been believed by many of the Whigs that a unanimous resignation on the part of the cabinet would force President Tyler to resign. The idea came from a misunderstanding of the British custom in similar cases, and it is an incident of great interest to the student of American history; but there was not the slightest chance that it should be realized. 
Had there been any such chance, Mr. Webster defeated it by staying at his post in order to finish the treaty with Great Britain. The Whigs were inclined to attribute his conduct to unworthy motives, and no sooner had the treaty been signed, on August 9, 1842, than the newspapers began calling upon him to resign. The treaty was ratified in the Senate by a vote of thirty-nine to nine, but it had still to be adopted by Parliament, and much needless excitement was occasioned on both sides of the ocean by the discovery of an old map in Paris, sustaining the British view of the northeastern boundary, and another in London, sustaining the American view. Mr. Webster remained at his post in spite of popular clamour, until he knew the treaty to be quite safe. In the hope of driving him from the cabinet, the Whigs in Massachusetts held a convention and declared that President Tyler was no longer a member of their party. On a visit to Boston, Mr. Webster made a noble speech in Faneuil Hall, September 30, I 842, in the course of which he declared that he was neither to be coaxed nor driven into an action which in his own judgment was not conducive to the best interests of the country. He knew very well that by such independence he was likely to injure his chances for nomination to the presidency. He knew that a movement in favour of Mr. Clay had begun in Massachusetts, and that his own course was adding greatly to the impetus of that movement. But his patriotism rose superior to all personal considerations. In May, I 843, having seen the treaty firmly established, he resigned the secretaryship and returned to the practice of his profession in Boston. In the canvass of 
I 844 he supported Mr. Clay in a series of able speeches. - On Mr. Choate's resignation, early in I845, Mr. Webster was reëlected to the Senate. The two principal questions of Mr. Polk's administration related to the partition of Oregon and the difficulties which led to the war with Mexico. The Democrats declared that we must have the whole of Oregon up to the parallel of $50^{\circ} 40^{\prime}$, although the $49^{\text {th }}$ parallel had already been suggested as a compromise line. In a very able speech at Faneuil Hall, Mr. Webster advocated the adoption of this compromise. The speech was widely read in England and on the continent of Europe, and Mr. Webster followed it up with a private letter to Mr. Macgregor of Glasgow, expressing a wish that the British government might see fit to offer the 49th parallel as a boundary line. The letter was shown to Lord Aberdeen, who adopted the suggestion, and the dispute accordingly ended in the partition of Oregon between the United States and Great Britain.

During the operations on the Texas frontier, which brought on war with Mexico, Mr. Webster was absent from Washington. In the summer of 1847 he travelled through the Southern states, and was everywhere received with much enthusiasm. He opposed the prosecution of the war for the sake of acquiring more territory, because he foresaw that such a policy must speedily lead to a dangerous agitation of the slavery question. The war brought General Zachary Taylor into the foreground as a candidate for the presidency, and some of the Whig managers actually proposed to nominate Mr. Webster as Vice-president on the same ticket with General Taylor. He indignantly refused to accept such a proposal; but Mr. Clay's defeat in 
I 844 had made many Whigs afraid to take him again as a candidate, Mr. Webster was thought to be altogether too independent, and there was a feeling that General Taylor was the most available candidate and the only one who could supplant Mr. Clay. These circumstances led to Taylor's nomination, which Mr. Webster at first declined to support. He disapproved of soldiers as Presidents, and characterized the nomination as "one not fit to be made." At the same time he was far from ready to support Mr. Van Buren and the Free-soil party, yet in his situation some decided action was necessary. Accordingly, in his speech at Marshfield, September I, I848, he declared that, as the choice was really between General Taylor and General Cass, he should support the former. It has been contended that in this $\mathrm{Mr}$. Webster made a great mistake, and that his true place in this canvass would have been with the Free-soil party. $\mathrm{He}$ had always been opposed to the further extension of slavery; but it is to be borne in mind that he looked with dread upon the rise of an antislavery party that should be supported only in the Northern states. Whatever tended to array the North and the South in opposition to each other, Mr. Webster wished especially to avoid. The ruling purpose of his life was to do what he could to prevent the outbreak of a conflict that might end in the disruption of the Union; and it may well have seemed that there was more safety in sustaining the Whig party in electing its candidate by the aid of Southern votes, than in helping into life a new party that should be purely sectional. At the same time, this cautious policy soon came to involve an amount of concession to Southern demands 
far greater than the rapidly growing antislavery sentiment in the Northern states would readily tolerate. No doubt Mr. Webster's policy in I 848 pointed logically toward his last great speech, March 7, 1850, in which he supported Mr. Clay's elaborate compromisesfor disposing of the difficulties which had grown out of the vast extension of territory consequent upon the Mexican War. This speech aroused intense indignation at the North, and especially in Massachusetts. It was regarded by many people as a deliberate sacrifice of principle to policy. In order to secure the admission of California to the Union as a free state, it had been thought necessary to make some grave concessions to the Southerners, and among these concessions was the fugitive slave law, to which Mr. Webster, out of his overmastering desire to serve the Union and avoid Civil War, felt himself obliged to yield a reluctant consent. It was the saddest moment in his career, and covered him with obloquy such as has sufficed in many minds to dim and obscure his great fame. For ordinary men to succumb under the stress of Southern bluster and dictation might seem pardonable; but it was felt that Daniel Webster should have been capable of better things. The swelling tide of popular sentiment in Massachusetts found expression in the pathetic but terrible sermon of Theodore Parker, preached just after Webster's death. Let us listen, after these fifty years, to the words of the preacher. "Do men now mourn for him, the great man eloquent? I put on sackcloth long ago. I mourned when he spoke the speech of the Seventh of March. I mourned for him when the fugitive slave bill passed Congress, ... when the kidnap- 
pers first came to Boston, . . . when Ellen Craft fled to my house for shelter and for succour, and for the first time in all my life I armed this hand.... I mourned when the court-house was hung in chains; when Thomas Sims, from his dungeon, sent out his petition for prayers, and the churches did not dare to pray. I mourned when that poor outcast in yonder dungeon sent for me to visit him, and when I took him by the hand which Daniel Webster was chaining in that hour. I mourned for Webster when we prayed our prayer and sang our psalm on Long Wharf in the morning's gray. I mourned then; I shall not cease to mourn. The flags will be removed from the streets, the cannon will sound their other notes of joy; but for me, I shall go mourning all my days. I shall refuse to be comforted. O Webster! Webster! would God that I had died for thee!"

There is no sense in which these words of the great scholar and preacher find a ready response in the hearts of all of us to-day. When we look only at the simple fact that the demon of slavery had conjured American politics into such a hopeless coil that a head so clear and a heart so kind as Daniel Webster's could for a moment be beguiled into making terms with it, our feeling is likely to be that which Parker expressed with such intensity. But is such a feeling really just to Webster? Is it the kind of feeling which the historian ought to entertain toward him? I think not. When Mr. Parker published his sermon, a few months afterward, he said in his preface that he was not so vain as to fancy that he had never been mistaken in his judgments upon Mr. Webster's actions or motives; the next generation would be better able to judge that 
statesman than his own contemporaries. And curiously enough, Mr. Parker added, by way of illustration, "Thomas Hutchinson and John Adams are better known now than at the day of their death; five and twenty years hence they will both be better known than at present." Of course the maker of this prophecy could not have dreamed of such a revolution as has since overtaken Hutchinson's reputation in the eyes of enlightened critics. The grand old Tory governor we no longer scout as a turncoat and traitor, but we honour him for the conscientious steadfastness with which he pursued a policy which we nevertheless pronounce mistaken. In Webster's case I believe we may go farther, and call his Seventh of March speech not only brave and honest, but statesmanlike and sound. When political passion finds free vent, it is apt to ascribe to men the lowest of motives. So Mr. Webster was accused of sacrificing his convictions and truckling to the South, in order to obtain Southern support for the presidency. But a comprehensive survey of his political career renders such an interpretation highly improbable. His conduct in remaining in Mr. Tyler's cabinet was one of the capital instances of moral courage to be found in American history; and his habitual independence of party was not the sort of thing that is wont to characterize timid seekers after the presidency. That Mr. Webster strongly wished to be President is not to be denied; but his mental attitude was the proud one that rather claimed it as a right than asked it as a favour. It was like the feeling of the soldier whose unexampled services have earned the right to assume the weightiest responsibility in the widest field of action. I do not believe that 
Mr. Webster ever sacrificed his convictions to selfish or unworthy motives. That he now and then sacrificed certain convictions to certain other convictions, when he felt himself driven to such a bitter alternative, I would freely admit; but that is a very different thing. In 1850 he subordinated his feelings about slavery, just as in 1828 he had subordinated his views on the tariff to the paramount necessity of saving the Union. In the later instance, as in the earlier, there was imminent danger of nullification or secession on the part of South Carolina; and in 1850 there was added danger that the Gulf states might follow the lead of their implacable sister. Compromise seemed necessary. We have seen that, as in $1833, \mathrm{Mr}$. Webster did not always approve of compromises; but there was a special reason for supporting those of Mr. Clay in 1850 . They seemed to Mr. Webster a conclusive settlement of the slavery question. The whole territory of the United States, as he said, was now covered with compromises, and the future destiny of every part, so far as the legal introduction of slavery was concerned, seemed to be decided. As for the regions to the west of Texas, he believed that slavery was ruled out by natural conditions of soil and climate, so that it was not necessary to protect them by a Wilmot proviso. As for the fugitive slave law, it was simply a provision for carrying into effect a clause of the Constitution, without which that instrument could never have been adopted and in the frequent infraction of which Mr. Webster saw a serious danger to the continuance of the Union. $\mathrm{He}$ therefore accepted the fugitive slave law as one feature in the proposed system of compromises; but in accepting it he offered amendments which, if they had 
been adopted, would have gone far toward depriving it of its most obnoxious and irritating features. By adopting these measures of compromise, Mr. Webster believed that the extension of slavery would have been given its final limit, that the North would by reason of its free labour increase in preponderance over the South, and that by and by the institution of slavery, hemmed in and denied further expansion, would die a natural death. That these views were mistaken, the events of the next ten years showed only too plainly; but how easy it is to be wise after the event, and how completely the result of a great struggle, such as our Civil War, casts into shadow the thoughts and motives of men whose lives were ended before it began, can only be well understood by the student whose view is accustomed to range far and wide over the field of history. In order to understand Mr. Webster's position, we must put ourselves back, in imagination, to that time when the doing away with that relic of barbarism, negro slavery, seemed as far off as the doing away with its twin sister, protectionism, seems to many of us to-day. Looking at Mr. Webster's acts in such a spirit, there can be no doubt that the compromises which he sustained had their practical value in postponing the inevitable conflict for ten years, during which the relative strength of the North was increasing, and a younger generation was growing up less tolerant of slavery and more ready to discard palliatives and achieve a radical cure. So far as Mr. Webster's moral attitude was concerned, although he was not prepared for the bitter hostility that his speech provoked in many quarters, he must nevertheless have known that it was quite as likely to injure him at the North as to 
gain support for him in the South; and his resolute adoption of a policy that he regarded as national rather than sectional was really an instance of high moral courage. It was, however, a concession that did violence to his sentiments of humanity, and the pain and uneasiness it occasioned is visible in some of his latest utterances.

On President Taylor's death, July 9, I850, Mr. Webster became President Fillmore's Secretary of State. An earnest attempt was made, on the part of his friends, to secure his nomination for the presidency in 1852 ; but on the first ballot in the convention he received only 29 votes, while there were I 3 I for General Scott, and I 33 for Mr. Fillmore. The efforts of Mr. Webster's adherents succeeded only in giving the nomination to Scott. The result was a grave disappointment to $\mathrm{Mr}$. Webster. He refused to support the nomination, and took no part in the campaign. His health was now rapidly failing. He left Washington, September 8, for the last time, and returned to Marshfield, which he never left again, except on September 20, for a brief call upon his physician in Boston.

On the $24^{\text {th }}$ of October, $185^{2}$, he died, and on the next day flags in all towns that had caught the sad news were at half-mast. I was a little boy then, and had never been in Boston or seen Mr. Webster; but I could not forget that day if I were to live a thousand years. Daniel Webster was dead. A godlike presence had gone from us. Life seemed smaller, lonelier, and meaner. I well remember catching myself wondering how the sun could rise and the daily events of life go on without Daniel Webster. 



\section{IN DEX}

\section{A}

Aberdeen, Lord, 400, 402.

Adams, John, urges appointment of Washington as commander-in-chief, 70-71 ; letter from, to Charles Lee, 75; jealousy between Hamilton and, 136-137, 174; death of, 181 ; aristocratic notion of location of political power, 223 ; Webster's eulogy on, 380.

Adams, John Quincy, 215, 311 ; as Monroe's Secretary of State upholds Jackson's course in Florida, 257; elected President, 281-282; "prince and protagonist of mugwumps," 322; and policy of internal improvements, 323 ; as a member of Congress in President Tyler's administration, $35^{8}$. Adams, Samuel (the elder), 17-18.

Adams, Samuel (the younger), 152, 154 , 176; British opinion of, 5; elected a member of the legislature, 31 ; attempt to arrest and send to England for trial, 32 ; demands removal of soldiers from Boston, 35 ; replies to Hutchinson's defence of supremacy of Parliament, 36-37; Hutchinson's criticisms of, in letters to Thomas Whately, 37; carries resolutions looking to a Continental Congress, IOI ; as a Federalist, 168-169.

Aix-la-Chapelle, treaty of, 20.

Alabama, admission of, to Union, 271.

Albany Congress of 1754, 23, 200.

Alien and sedition laws, the, $135^{-1} 3^{6}$, I 74, 2I I-213.

Ambrister, Robert, 256, 257, 261-262.

"American Notes," Dickens's, 275.

"American system," the, 323, 382-383.

André, Major, Hamilton's acquaintanceship with, 112.
Annapolis convention of $1786,117-118$, 196.

Anti-federalism, the beginning of, 117, 168; Governor George Clinton a champion of, 118-119, 124; Melanchthon Smith defends, 125; the Waterloo of, 125.

Antinomians, 365 .

"Anything to beat Van Buren," 349.

Arbuthnot, Alexander, 256, 257, 261262.

"Aristocracy of office," theory of an, 289.

Armstrong, Secretary of War, 24I, 245.

Arnold, Benedict, comparative dignity of character of, beside that of Charles Lee, 97-98.

Ashburton treaty, 399-400.

Assumption of state debts by federal government, 127-130; Madison opposed to, 208-209.

\section{B}

Badger, George E., 356.

Bancroft, George, 23.

Bank, National, established by Hamilton and Gouverneur Morris, 114, 133; opposed by Madison, 209; Jackson's opposition to and attacks on, $235,236,302-303$; removal of deposits from, 304, 336-337; comments on destruction of, $3 \mathrm{II}$; question of rechartering in 1811,329 ; Tyler's opposition to, 336-338; President Tyler and, 352-353; permanent defeat of, 357 .

Bank, Fiscal, 353-356.

Banking, wildcat, in early New England, 13-22; enormous development of, before panic of 1837,346 . See Bank, National. 
Barre, town of, originally named Hutchinson, 47.

Barrington, Lord, Charles Lee's letter to, $71-72$.

Barry, W. T., 286.

Bayard, Richard H., 353.

Belcher, Governor Jonathan, 14-20.

Bell, John, 356.

Bellamy, Dr. Joseph, 374 .

Bennet Street Grammar School, Boston, Io, 47 .

Bentham, Jeremy, 44.

Benton, Thomas H., 283, 302, 325, 334, $336,337,33^{8}, 360,383,389,392$; early affray with Jackson, 24I-242; persistency in having resolution of censure on Jackson expunged, 305306.

Bernard, Governor Francis, 25, 28, 30, 3I, 34.

Berrien, J. M., 285, 292.

Bibles, old ladies in Connecticut hide, on election of Jefferson, $\mathbf{I} 75$.

Birney, James, 350.

Blair, Francis Preston, 295, 325, 336, 36o.

Blount, William, 23I.

“Boiling Water," Mohawk nickname of Charles Lee, 60.

Boone, Daniel, 223.

Boott, Dr. Francis, $390 \mathrm{n}$.

Boston Massacre, the, 34-35.

Botts, John Minor, 354.

Brackenridge, H. M., 280.

Branch, John, 285, 292.

Braddock's defeat, $5^{8}$; recalled by Madison as a boy, 189 .

Brent, Richard, 329, 338.

"Brother Jonathan," Trumbull the original, 12.

Brown, Rev. Francis, 374.

Bryant, William Cullen, 309.

Bunbury, Sir William, 63 .

Bunker Hill orations, Webster's, 380 .

Burgoyne, General, as a target for silly remarks by American historians, 5; Charles Lee in Portugal with, 63; Charles Lee's correspondence in America with, 74 .

Burke, Edmund, at famous meeting of privy council, 44; Charles Lee writes to, 69; "Letters on a Regicide Peace," I66.

Burr, Aaron, 138, 175; elected Vicepresident, I39; prevented by Hamilton from becoming governor of New York, 140; duel with Hamilton, 140; visit to Andrew Jackson, 240.

Butler, Colonel Edward, 290-29I.

“Cabbage-planting enterprise," Charles Lee derides expedition against Louisburg as a, 60.

Cabinet, Hamilton and Jefferson in Washington's, 125, 167; Jackson's first, 285; the "kitchen," 286,295 ; Jackson's second, 293-294; resignation of members of Tyler's, 356 , 400-401.

Calhoun, elected Vice-president, 28I ; reëlected, 285 ; misrepresented to Jackson, 29I-292; succeeds Hayne in Senate, 298.

Campbell, G. W., unpublished letter of Jackson's to, 259-264.

Capitalists, Hamilton aimed at alliance of government with, 130. See Plutocracy.

Capitals, state, reason for location of, 162.

Carlyle, Thomas, on Daniel Webster, 389.

Carr, Dabney, $163,180$.

Cass, Lewis, 294.

Censure, resolution of, on President Jackson, 305-306, 338, 396.

Charleston, Charles Lee at battle of, 7778.

Chatham, Lord, admiration of Americans for, 4 .

Cherokee Indians, disputes between Georgia and, 296.

Chesapeake, affair of the, 214 .

Chesapeake and Ohio Canal, origin of, 196.

Choate, Rufus, $353,402$.

Chotzim, Charles Lee at battle of, 66 .

Church, disestablishment of, in Virginia, 159-160, 190-191. 
Cities, growth of, in United States, 309, 344 .

Civil service, previous to Jackson's administration, 287-288; Jackson's treatment of, 288-290; in HarrisonTyler administration, 350-351.

Clay, Henry, chusen Speaker of the House of Representatives, 215 ; beginning of feud between Jackson and, 258, 279; candidacy of, for presidency, 28I ; becomes J. Q. Adams's Secretary of State, 283; charged with making a bargain with Adams, 283284; forces United States Bank question to the foreground, 302; candidate for presidency a second time, 303 ; carries resolution of censure on Jackson, 305, 338; election of Harrison considered a victory for, $35 \mathrm{I}$; struggle with Tyler, 35 I-358.

Cleveland, Grover, 1 74-175.

Clinton, De Witt, 216.

Clinton, George, as an Anti-fecleralist, I18-I19, I68; elected Vice-president, 215.

Clinton, Sir Henry, succeeds Lord Howe in America, 87; possibility of an understanding with Lee at Monmouth, 92-93.

Coddington, William, 8.

Commerce, difficulties in regulating interstate, at close of Revolution, 196-198.

Compromise act of $1833,35^{8}$.

Connecticut compromise, the, 202.

Constitution of United States, Madison's share in framing, 122.

"Cunstitu ion not a Compact between Sovereign States," Webster's, 393394 .

Conway, Thomas, 56 .

Conway cabal, the, 79,87 .

Cooper, James Fennimore, 309.

Cooper, Dr. Myles, 69, 108.

Cornwallis, Lord, silliness of remarks by some historians as applied to, 5; in Virginia, 163.

“Corporal's guard, the," 357.

Cotton, John, 7 .

Crawford, W. H., 253, 280 n., 281, 286, 383.
Creeks, Jackson's campaign against, 243-244.

"Crime and Punishment," Beccaria's, 64.

Crimes act, the, $38 \mathrm{r}$.

Crisis of $1837,343-348$.

Crittenden, John J., 356.

Crockett, David, 244.

Cruger, Nicholas, 104.

"Cruising convention," the, 400 .

Currency, decimal, devised by Jefferson and Gouverneur Morris, 164.

Curtis, Benjamin, 50.

Cushing, Thomas, receives the Whately letters, 39.

\section{D}

Dartmouth, Lord, meets Hutchinson in London, 47.

Dartmouth College, Webster graduated from, 368 .

Dartmouth College case, the, 373-379.

Day, James, quoted, $27 \mathrm{I} \mathrm{n}$.

Debt, payment of national, in 1835,344 .

Debts, of United States, at close of Revolution, 126, 192-193; assump. tion of state, 127-130; assumption of state, opposed by Madison, 208$2 c 9$.

Declaration of Independence drawn up by Jefferson, $155^{-1} 57$.

De Kalb, 56.

Democrats, origin of the, 324-325.

“Demos Krateo" principle, the, 337, 395.

Deposits, removal of, from United States Bank, 304, 336-337; results of removal of, 346 .

Dickens, Charles, comments on America, 275 .

Dickinson, Charles, Jackson's duel with, 239.

Disestablishment of Church in Virginia, 159-160; Madison's connection with, 190-191.

Dix, John A., extract from letter of, $280 \mathrm{n}$.

"Domestic Manners of the Americans," Mrs. Trollope's, 275.

Donoughmore, Irish earls of, 7 .

Draper, Dr. Lyman, I88. 
Dress, Webster's style of, $270,389 \mathrm{n}$.

Dryden, Sir Erasmus, 7.

Duane, W. J., 304, 396.

Duel, Charles Lee's, in Vienna, 66-67 ; Lee declines to fight, with Steuben, 94; Lee wounded by Laurens in a, 95, 111-112; Hamilton's son killed in a, 139 ; the Burr-Hamilton, 14014I ; Andrew Jackson's, with Avery, 238; Jackson challenges General Scott to a, 253 ; between John Randolph and Henry Clay, 283 ; Jackson dies as result of a wound received in a, 308; Randolph challenges Webster to a, 372 .

Duels, plan to kill Hamilton by a series of, $\mathrm{II}_{7}$; discredited in Northern states as a result of Hamilton's death, I4I ; caused by the "Mrs. Eaton" episode, 292.

\section{E}

Eastman, Abigail, 367 .

Eaton, John H., 285, 290, 292.

Eaton, Mrs. John H., episode of, 290294.

Eliot, Rev. Andrew, 30.

Eliot school, Boston, originally named the Hutchinson, 47.

Ellsworth, William, 190.

Embargo, Jefferson's, 214-215, 278, 322; Webster's pamphlet criticising, 369370 ; jingle about the, $369 \mathrm{n}$.

England, yeomanry and country squires of, compared with French classes, 145-148; arrogance of, in War of I $812,247-248$.

Entail, system of, in Virginia, abolished, 157-158.

"Era of good feeling," the, 279.

Erie Canal, results of completion of, 344 .

Everett, Edward, 399.

Ewing, Thomas, 353, 356.

Exeter Academy, Webster at, 367.

\section{F}

"Farmer Refuted, The," Hamilton's, 107-108.
Farragut, David, sent to South Carolina by Jackson, 298.

"Federalist," the, 122-123, 188, 204.

Federalist party, building up of, I14125, 168; victory of, over Anti. federalists, 125; cause of downfall of, I34; absorbed by Republican party, 207, 215 .

Fiscal corporation bill, 353-355.

Florida, base for British operations in War of 1812, 245; Jackson drives British from, $245^{-246}$; in 1816 becomes a nest of outlaws, 253-254; invaded by Jackson in 1818, 255257; purchased by United States from Spain, 258.

Floyd, John, 303, 334.

Foote, Samuel A., 386.

Foote's resolutions, 297, 386-387.

Force Bill, the, 335-336, 391 .

Fort Bowyer, British defeat at, 245.

Forward, Walter, 356.

France, peasantry of, compared with yeomanry of England, 145-148; Jefferson's sojourn in, 164-165; Jackson settles American difficulties with, 307-308.

Frankland, Sir Harry, house of, 28.

Franklin, Benjamin, a delegate to Albany Congress, 23 ; comes into possession of Whately's correspondence, $3^{8-}$ 39 ; abused by Wedderburn before privy council, 44-45; dismissed from postmaster-generalship, 45 ; description of Earl of Loudoun, 60 ; letter from, to Charles Lee, 76 ; a prototype of the "franklins" of England, 146-147; Jefferson succeeds, in France, 164.

Franklins, the, in England, 146.

Free trade speech, Webster's, 382-383.

Fugitive slave law, Webster's attitude on, 404-409.

Fulton, Robert, 271 .

G

"Gag resolution," the, 342 .

Gage, Thomas, serves under Braddock in America as lieutenant-colonel, 
$5^{8}$; in battle of Ticonderoga, 61 ; takes command in Boston, 46, IOI.

Gallatin, Albert, 223.

Gallicism, Jefferson's so-called, $155^{-1} 57$.

Gantt, Colonel Thomas Tasker, 259, 264 ; Mrs. E. B. Lee's letter to, quoted, 292 n., $298 \mathrm{n}$.

Gates, Horatio, first acquaintance of Charles Lee with, 58; Charles Lee's friendship with, 70; Hamilton regains Washington's troops from, II I.

George III., accession of, to throne, 25-26.

Georgia, disputes with Cherokee Indians in, 296.

Giles, William E., 329, 338.

Girdlestone, Dr. Thomas, on Charles Lee as the author of "Letters of Junius," 96-97.

Gladstone, W. E., end of army purchase system by, 60 .

Gore, Christopher, 369.

Gower, Lord President of privy council, 44.

Granger, Francis, 356.

Grayson, William, 206.

Great Britain, arrogance of, in War of I $812,247-248$.

Green, Duff, 286, 295.

Greene, D. H., quoted concerning relationship of Charles and Robert E. Lee, $57 \mathrm{n}$.

Greene, Nathanael, mentions Hamilton to Washington, 109.

Gridley, Jeremiah, 25, 26.

Griswold, Roger, 242.

\section{H}

Hallowell, Briggs, 28.

Hamilton, Alexander, delivers patriotic address when seventeen years of age, 103; birth and family of, 104; enters King's College, ro6; on Washington's staff, 109-1 12; marries Elizabeth Schuyler, II3; admitted to bar in Albany, $\mathbf{I r}_{3}$; aids in establishment of Bank of North America, 114, 133; delegate to Congress in 1782, 114; first famous law case, II6-II7; delegate to conventions at Annapolis and Philadelphia, 11 7-118; joint author with Madison of "Federalist," 122-1 23, 188, 204; wins New York over to ratifying federal Constitution, 123-125; Washington's Secretary of Treasury, 125; proposal for federal assumption of state debts, 127; aims to insure stability of government by alliance with capitalists, 130; an advocate of protective tariff, 132 ; feud with Jefferson, I34-135, 167-168; jealousy between John Adams and, 136-137, 174; killed by Burr in duel, 140.

Hamilton, Philip, killed in a duel, 139.

Hamiltonians, comparison of, with Tories, I 70-1 73 .

Hanging Rock, Jackson present at fight of, 229.

Harcourt, Lieutenant-colonel, capture of Charles Lee by, $8 \mathrm{r}-82$.

Hard cider campaign, the, 349-350.

Harrison, William Henry, 206, 242; birth and early career of, 340; political life, 34I; second nomination for presidency, 349; elected President, 350; death of, $35 \mathrm{I}$.

"Harry of the West," 278.

Hartford convention, the, $247,278,322$, 37 I.

Harvard College, Thomas Hutchinson at, II; versus the backwoods, as illustrated by J. Q. Adams and Jackson, 284 .

Hawke, Lord Edward, I 2.

Hawthorne, Nathaniel, 309.

Hayne, Robert Y., 387 .

"Hayne, Reply to." See "Reply to Hayne."

Hearts of Oak, Hamilton a member of the, 109.

Heath, General, 79-8o.

Henry, Patrick, British opinion of, 5; as an Anti-federalist, I68, 205, 206, 372 ; advocates extension of powers of federal government, 208.

Hermitage, the, Jackson's home at, 308. 
Hervey, Lady, a cornet in British regiment from infancy, 57-58.

Hill, Isaac, 286.

Holmes, O. W., 309.

Holy Alliance, Webster's speech against, $381-382$.

Holy Ground, the, 244 .

Houston, Samuel, 244.

Howe, Lord, death of, in battle of Ticonderoga, 6I.

Howe, Sir William, and Charles Lee, 83-86.

Hume, David, Charles Lee's epistle to, 64-65.

Hutchinson, Anne, 7-8.

Hutchinson, Thomas, ancestry of, 7-10; childhood of, IO-II; at Harvard, I1-12; marriage, I2; beginning of public life, 13; member of General Court, 13-20; Speaker of House, 20-2I ; member of council, 22; residence on Milton Hill, 22-23; appointed judge of probate and justice of common pleas, 23 ; loss of wife, 23; appointed lieutenant-governor, 24; chief justice, 25; house of, wrecked by a mob, 30; appointed governor of Massachusetts, 35; and the Boston Massacre, 34-35; masterly statement of doctrine of supremacy of Parliament, 36; adjusts boundary line between New York and Massachusetts, 37; correspondence with Thomas Whately, 37-38; goes to England, 46; met by Lord Dartmouth, 47; refuses a baronetcy, 48; death of, 49; his character and intellectual powers, 49-5I ; analogy between case of, and Webster's, 406.

Hutchinson Mob, the, 30-3I.

Hutchinson, town of, name changed to Barre, 47.

\section{I}

Illinois, admission of, to Union, 271.

Impost law of 1783 , proposed, 192-193.

Indemnification to Charles Lee, American, $71-73,78$.

"Indian War," Church's, 12.

Indiana, admission of, to Union, 271.
Ingham, S. D., 285, 292.

Internal improvements, policy of, 323 , $371-372$.

"Iolanthe," quoted, 319-320.

Irving, Washington, 309.

Izard, Ralph, on Wedderburn's abuse of Franklin, 45.

Jackson, Andrew, family of, and birth, 228-229; prisoner at Camden during Revolutionary War, 230; story of the British officer's boots, 230 ; studieslaw and appointed public prosecutor in North Carolina, 230 ; story of Mrs. Robards, 232-234 ; marriage, 234; representative in Congress from Tennessee, 235; elected to Senate, 237; judge in Supreme Court of Tennessee, 238; duel with Dickinson, 239-240 ; in War of 1812,241 ; nicknamed "Old Hickory," 24I ; in Creek War, 243-245; appointed major-general, 245 ; at battle of New Orleans, 250-25I ; invades Florida in $1818,255^{-256}$; beginning of feud with Clay, 258, 279; appointed governor of Florida, 258; becomes United States Senator, 279; defeated by J. Q. Adams for presidency, 28I282 ; defeats Adams in 1828, 285 ; death of Mrs. Jackson, 29I ; reelected President, 303; death, 308; remarkable character of the period of his two presidential terms, 309 ; Webster's support of, 391-392.

Jackson, Mrs. Andrew, death of, 291. See Robards, Mrs. Lewis.

Jay, John, Hamilton first meets, 106; a delegate to Continental Congress, 152-153; essays in "Federalist" by, 204.

Jay's treaty, I35, 209, 210, 235-236.

Jefferson, Thomas, birth and ancestry of, I5O; marriage, 151 ; elected delegate to Continental Congress, 152 ; draws up Declaration of Independence, 155-157; an active member of Virginia legislature, $157-163$; governor 
of Virginia in 1779,163 ; death of wife, 163 ; elected to Congress, 163 ; minister to France, 164-165; becomes Washington's Secretary of State, 125, 167; Vice-president, 174; presidential campaign of, $174^{-1} 76$; buys the Mississippi territory of Napoleon, 177 ; reëlection to presidency, 180; death, 180; Madison's intimacy with, 189 ; responsibility of, for theory of nullification, 212 ; treatment of civil service by, $287-288$; mantle of, fell on Van Buren, 3II312; Webster's eulogy on, 380 .

Jeffersonians, comparison of, with English Liberals, 170-1 73.

Johnson, George, letter from, to Charles Lee, 88.

Johnson, Richard, 342.

Johnson, Sir William, 59.

Judges, election of, instead of appointment, a crying abomination, 272.

\section{K}

Kant, Immanuel, on Wedderburn's abuse of Franklin, 45 .

Kendall, Amos, 286, 295, 304.

Kentucky resolutions of $1798,174,21$ I213.

King Philip's War, 9.

King, Rufus, 203, 278, 322.

King's College, Dr. Myles Cooper president of, 69, 108; Hamilton a student at, Io6.

“ Kitchen cabinet," Jackson's, 286; break in the, 295 .

Knox, General Henry, III, I37.

Knox, Dr. Hugh, 104, 105.

Kosciuszko, in America, 56.

\section{L}

Lafayette, Marquis de, $56,88,89$; love of, for Hamilton, Iri ; innocent cause of disagreement between Washington and Hamilton, I 12.

Land Bank of 1740, 16-17.

Langworthy, Edward, 66, 77 .

Lansing, John, II9.
Laurens, Colonel, Charles Lee's duel with, 95, $111-112$.

Lee, Charles, wrongly stated to be father of Robert E. Lee, 56-57; ancestry of, 57 ; birth of, 57 ; commissioned lieutenant in the British army, $5^{8}$; in America with Braddock's army, $5^{8}$; adopted by Mohawk tribe, 59; in Earl of Loudoun's expedition against Louisburg, 60 ; wounded in battle of Ticonderuga, $6 \mathrm{r}$; narrow escape from assassination on Long Island, 62 ; return to. England in 1761,63 ; with Burgoyne in Portugal, 63; in Poland, 66; arrives in America in 1773,67 ; appointed second major-general in Continental army, 70; letter to Lord Barrington, 71-72; service in Continental army, 74-81 ; at battle of Charleston, 7778 ; captured by British, 82 ; conduct during captivity, $83-86$; exchanged for General Richard Prescott, 86; treason at Monmouth, 8991; in disgrace, 92; death, 95; pretensions to authorship of "Letters of Junius," 95-97 ; Benedict Arnold a dignified character in comparison with, 97-98.

Lee, Mrs. Elizabeth B., 259; letter from, to Colonel Gantt, quoted, 292 n., $298 \mathrm{n}$.

Lee, Henry, 206, 303.

Lee, Richard Henry, r 55, 205.

Lee, Robert E., Charles Lee wrongly stated to be the father of, $56-57$.

Legaré, Hugh S., 356.

Leigh, Benjamin Watkins, 338.

Leopard, affair of the, 2I4.

Lepel, Colonel, makes his infant daughter a cornet in British regiment, 57.

"Letters and Times of the Tylers," 327.

"Letters of Junius," Charles Lee pretends to authorship of, 95-97.

" Letters on a Regicide Peace," Burke's, I66.

Lewis, William B., 279, 286, 292.

Liberalists, English, chief characteristics of, $171-172$.

Lippe-Schaumburg, Count von, 63 . 
Literature, the blooming time of American, 309.

Little Belt, affair of the, 215 .

Livingston, Edward, 249, 293.

Log cabin campaign, the, 349-350.

Longfellow, H. W., 309.

Louisburg, fortress of, 20-2I ; Earl of Loudoun's expedition against, 60 .

Louisiana purchase, 177,321 .

Loyalists, American, hard position of, in history, 5-6.

Lyon, Matthew, 242.

\section{M}

McCarthy, Daniel, on Charles Lee as author of " Letters of Junius," 96.

McCay, Spruce, 230.

Macdougall, Alexander, 103.

McLane, Louis, 293-294, 304.

McLean, John, 356 .

McMurdo, Tyler's schoolmaster, 328.

Madison, James, 157 , I68, I76 ; Hamilton first comes in contact with, I I4; share of, in framing the Constitution, 122 ; joint author with Hamilton of the "Federalist," I 22-1 23, 188, 204 ; ancestry of, and birth, 188; intimacy with Jefferson, 189; at Princeton College, 189 ; entrance to public life, 190; delegate to Continental Congress, I91 ; member of Virginia legislature, 194; delegate to Annapolis and Philadelphia conventions, 198; the "Virginia plan" devised by, 199-201 ; services in securing ratification of Constitution by Virginia, 204-206; elected to first national House of Representatives, 206; leader of the opposition, 207-210; marriage, 210; draws up Virginia resolutions of 1798, 210; becomes Jefferson's Secretary of State, 2I3-2I4; elected President, 215; reëlected President, 216 ; old age, 217 ; cause for dislike of Jackson, 240.

Maine, admission of, to Union, 271.

Mangum, Person, 34I.

Marcy, W. L., declares that "to the victors belong the spoils," 288 .
Marshall, Chief Justice, I85, I86, I90, 206 ; ruling of, on power of Federal government to acquire territory, $\mathbf{1} 78$; the Dartmouth College case before, 376-379.

Marshfield, Webster's home at, 397-398.

"Martin Chuzzlewit" quoted, 275, 347.

Maryland convention of $1776,76-77$.

Mason, Colonel George, 157, 161, 198, 206.

Mason, Jeremiah, 369, 375 .

Mather, Rev. Samuel, 30.

Maysville turnpike bill, 334 .

Mifflin, Thomas, 70.

Milton, Hutchinson's residence in, 2223.

Mimms, Fort, massacre of, 243.

Mississippi, admission of, to Union, $27 \mathbf{I}$.

Mississippi River, free navigation of, 177, I91-192, 199.

Missouri, admission of, to Union, 27I, $330-332,372$.

Missouri Compromise bill, 330-332.

Mobile occupied by General Jackson, 245.

Mohawks, Charles Lee and the, 59-60. Monmouth Court House, battle of, 8991.

Monongahela, battle of the, 58 .

Monroe, James, 206, 322 ; elected President, 278.

Monticello, Jefferson's home at, 163 , I 79-180.

Montpelier, Madison's home at, 2ro, 217.

Morris, Gouverneur, aids in establishment of Bank of North America, 114 ; subscribes to the "three-fifths rule," 203; singular views of, as to so-called back-country people, 22I222.

Morris, Robert, lends Charles Lee $£ 3000,70$; aids in establishment of Bank of North America, II4.

Morton, Major Jacob, testimony of, concerning. Washington and Lee at Monmouth, $90 \mathrm{n}$.

Moultrie, Colonel William, 77.

Mugwumps, J. Q. Adams protagonist of, 322 . 


\section{N}

National bank. See Bank, National.

National Republicans, the, 324 .

Naturalization in United States, 162163.

Navigation of Mississippi, 177, 191-192, 199.

Navigation Acts, trouble caused in Boston by enforcement of, 28 .

New England Confederacy, 8.

"New England Memorial," Morton's, 12.

New Orleans, Jackson at, 246, 248-252 ; battle of, $250-251,278$.

Newspaper, development of modern type of, 309.

Non-intercourse acts, the, 215.

Northeastern boundary question, 399400.

"Notes on Virginia," Jefferson's, 159160, 164-165.

Nullification during Jackson's administrations, 295, 297-300, 31 2-313.

\section{$\mathrm{O}$}

Ohio, admission of, to Union, 271.

Old Corner Bookstore, Boston, William Hutchinson's house on site of, 8 .

"Old Hickory," Jackson receives nickname of, 241.

Oliver, Andrew, correspondence between

Thomas Whately and, 37-38.

Ordinance of $1787,164,225$.

Oregon question, the, 221, 402.

Otis, James, 25, 74-75.

Overton, Judge, 232, 238, 239-240, 255.

\section{$\mathbf{P}$}

Paine, Thomas, 64.

Pakenham, Sir Edward, 250, $25 \mathrm{I}$.

Pamphleteer, Charles Lee as a, 64-65, 73.

Panic of $1837,343-348$.

Paper money, in 1690, 13; in New England in eighteenth century, 13I5, 2I-22; issued by Continental Congress, 192-193; virulent craze for, in $1786,195-196$; before panic of $1837,345-347$.

Parker, Theodore, sermon by, on Webster and fugitive slave law, 404405.

Parkman, Francis, 23.

Parties, political, earliest division of American, 168; comparison of, with English, 170-173; division into Whigs and Democrats, 295; development of, to $1832,317-325$.

Paxton, Charles, correspondence between Thomas Whately and, 3738.

Pearl Street, Boston, originally named Hutchinson Street, 47.

Pendleton, Edmund, I58, 206.

Pensacola captured by Jackson, 257, 260-26I.

"Pet banks," the, 305.

Philadelphia convention of 1787,118 , 198.

Phillips, Stephen C., 349 n.

Pickering, Timothy, 140, 141, 223, 277, 286, 37 I .

Pinckney, Cotesworth, 137, 180, 203, $215,223$.

Pinckney, Thomas, 203, 223 ; candidacy of, for presidency, 136 .

Plutocracy, gravest danger to our country is a government by a, 130,179 .

“Pocket veto," Jackson's, 296.

Poland, Charles Lee in, 66.

Potomac Company, the, 196.

Pownall, Governor Thomas, 24-25.

Presbyterian junto, the, 103.

Prescott, General Richard, Charles Lee exchanged for, 86.

Prescott, W. H., 309.

President, affair of the, 215.

Priestley, Dr., 44, 45.

Primogeniture, law of, in Virginia, attacked by Jefferson, $15^{8}$.

Princeton College, Hamilton applies for admission to, 106 ; Madison a student at, 189 .

Protection of American industries. See Tariff, protective.

Provincialism, period of, in America, $267-276$. 
Pulaski, Count, 56.

Purchase system, end of, in British army, 60.

Putnam, Israel, in battle of Ticonderoga, 61.

\section{Q}

Quincy, Josiah, 178, 249.

\section{$\mathrm{R}$}

Railroads, development of, in United States, 309, 322-323, 344.

Randolph, Edmund, 198, 199, 206.

Randolph, John, 283, 333, 372 .

"Religious Freedom Act," Madison's, 194-195.

"Reply to Hayne," Webster's, 297, 312, 387-391.

Republican party, absorbs Federalists, 207,215 ; divided in $1824-1832$ on questions of internal improvements, tariff, and national bank, 324 .

Revenue question, the, 131-133, 167, 192-193.

Revolution, French, I66-167.

Rhea, John, 255.

Richmond, state capital of Virginia removed to, 162.

Rives, William C., 343, 353.

Rivington, James, 108.

Road-building, era of, in United States, 344.

Robards, Captain Lewis, 232-234.

Robards, Mrs. Rachel, 232-234, 290291.

Robertson, Donald, 188.

Robertson, James, 223.

Robertson, William, letter from, to Dr. Fiske, $90 \mathrm{n}$.

Rockingham, Lord, 3 I.

Rockingham Memorial, the, 370.

Rodney, Thomas, conversation of, with Charles Lee concerning "Letters of Junius," 95-97.

Rousseau, Jefferson not in same class with, 154 .

Rush, Dr. Benjamin, correspondence of, with Charles Lee, 76, 79 .

Rutledge, Edward, 76, 153, 203.

\section{$\mathbf{S}$}

Sargent, Lucius Manlius, 369 n.

Schuyler, Elizabeth, marriage of, to Hamilton, I 13.

Schuyler, Mrs., and Charles Lee, 6I-62. Scotch-Irish breed in the West, 225, 228.

Scott, John Morin, I03.

Scott, General, 253, 298.

Seabury, Samuel, 107.

Sears, Isaac, 103, ro8.

Seventh of March speech, Webster's, 404-406.

Sevier, John, 238-239.

Shays's rebellion, 118, 126, 199.

Shepard, Edward M., 348.

Shirley, Governor William, 20.

Slavery, Jefferson an advocate of abolition of, 158-159; prohibited north of Ohio River, 164; Tyler's views of, $330-332$.

Smith, Goldwin, misconception of, concerning Madison, 187 .

Smith, Jeremiah, 375.

Smith, Melanchthon, 125.

Southard, William L., 356.

South Carolina, ordinance of nullification in, 297-299, 326, 386-394.

Specie Bank of 1740, 16-17.

Specie circular, the, 347,348 .

Spencer, Herbert, should be read by every American, 310.

Spoils system, inauguration of the, 288 .

Stamp Act, opposition to, in Boston, 28-31.

Stark, John, in battle of Ticonderoga, 61 .

State debts, federal assumption of, 127 I30.

State rights, question of, in Hamilton's time, I 18-I2I.

State Rights Whigs, Southern strict constructionists call themselves, 339; Tyler, as leader of, elected $\mathrm{V}$ : e-president, 349-350; break with Nurthern Whigs over annexation of Texas, 359; join the Democrats, 360 .

"Stepfather of his country," Washington called the, 135 .

Steuben, Baron von, 88, 94, II I. 
Strachey, Sir Henry, preservation of Charles Lee papers by, 72,85 .

"Strictures on a Friendly Address to all Reasonable Americans," Charles Lee's, 69.

Subtreasuries, establishment of, 349; bill for abolishing, passed, $35^{2}$.

"Summary View of Rights of British America, A," Jefferson's, ${ }^{2} 2$.

Surplus, distribution of, 346-347.

\section{$\mathrm{T}$}

Talladega, battle of, 243 .

Tallasahatchee, battle of, 243 .

Taney, R. B., 294, 304.

"Tariff of abominations," 297, 334, 384 . Tariff, protective, Hamilton an advocate of, 132; Jackson opposed to a, 297 ; Clay favours, 323 ; John Tyler and, $332,357-35^{8}$; Webster's attitude on a, 371, 384-386.

Tarleton, Banastre, 81-82.

Taylor, Zachary, 402-403.

Tazewell, Littleton, 330.

Tea ships in Boston harbour, 40-4I.

Tecumseh, 242-243, 34I.

Temple, Mr., duel of, with William Whately, 40.

Tennessee admitted to Union, 235.

Thames, battle of the, 243, 340-341.

Thomas, Captain John, 397.

"Three-fifths rule," compromise of the, 203.

Ticonderoga, battle of, $6 \mathbf{1}$.

Tilden, Samuel J., 175.

Tippecanoe, battle of, 242, 340 .

"Tippecanoe and Tyler too," 350.

Toast, Jackson's immortal Union, 297, 334.

Tohopeka, battle of, 244 .

Tories, English, chief characteristics of, I 71-173; attempt to call Jackson's followers, 339 .

Townshend Acts, 3 I.

Traffic, interstate, just after the Revolution, 196-198.

Trimble, Robert, 330.

Trollope, Mrs., on America, 275.

Trumbull, Jonathan, 12.
Tyler, John (the elder), 197, 327-328.

Tyler, John, birth of, 328 ; member of legislature, 329 ; elected to national House, 330 ; arguments on slavery question, 330-332 ; opposes protective tariff, 332 ; governor of Virginia, 333 ; elected to Senate, 333 ; break with President Jackson, 335; opposed to United States Bank, 336338 ; vice-presidential campaigns, 340-342, 349-350; becomes President on Harrison's death, 35I ; United States Bank question, 352353 ; contest with Congress on Fiscal Bank bill, 353-358; allied with Democrats on Texas question, 360 .

Tyler, Lyon Gardiner, 327.

\section{U}

United States Bank. See Bank, National. Upshur, Abel P., 356.

\section{V}

Van Buren, Martin, Jackson's Secretary of State, 285 ; resigns secretaryship, 292 ; nominated minister to England but not confirmed, 295; mantle of Jefferson fell on, 31I-312; elected President, 342 ; and the panic of $1837,348-350$; defeated in presidential campaign of 1840 by Harrison, 350.

"Van Buren," E. M. Shepard's, 348.

"Virginia dynasty" of Presidents, the, 279.

"Virginia plan," the, 199, 200, 201, 202, 217-218.

Virginia resolutions of $1798,174,210-$ 21 I.

\section{W}

War of 1812, 216-21 7, 241-252.

Ward, General Artemas, 70-71, 78.

Warren, Mercy, description of Charles Lee by, 68 .

Washington Benevolent Society of Portsmouth, 370 .

Washington, city of, bargain over loca- 
tion of, 129-130; burned by the British, 216-21 7, 245, 246.

Washington, George, admiration of British for, 4; Charles Lee's first acquaintance with, $5^{8}$; receives Charles Lee at Mount Vernon, 67; reasons for appointment as commander-in-chief, 70; at battle of Monmouth, 89-92; altercation with Hamilton, I1 2-I I3; chooses Hamilton and Jefferson for members of his cabinet, 125, 167; termed "the stepfather of his country," I35; appointed by Adams commander of army for expected war with France, 137; first president of Potomac Company, i96.

Watkins, Tobias, 290.

Wayne, Anthony, 89 .

Weathersford, 243-244.

Webster, Daniel, birth of, 367 ; graduated from Dartmouth, 368 ; marriage, 369; elected to Congress, 370; the Dartmouth College case, 373-379; Bunker Hill orations and eulogy on Adams and Jefferson, 380$38 \mathrm{I}$; represents the Boston district in Congress, $381-384$; the "free trade speech," 382-383; elected to Senate, 384 ; attitude on protection, 384-386; the "Reply to Hayne," 312, 387-391; “The Constitution not a Compact between Sovereign States," 393-394; speech in White murder trial, 397; home at Marshfield, 397-398; second marriage, 398; candidate for presidency, 34 I, 398, 409; Secretary of State in Harrison-Tyler administration, 35 I, 356, 399-40I; attitude on fugitive slave law, 404-409; Seventh of March speech, 404; Fillmore's Secretary of State, 409; death, 409; mode of dress, $270,389 \mathrm{n}$.

Webster, Colonel Ebenezer, 365-367.

Webster, Ezekiel, 369, 378, 398.

Wedderburn, David, abuse of Franklin by, 44-45.

“Westchester Farmer, A," I07.
Whately, William, 38, 40.

Whately letters, the, $37-38$; published in America, 40; effect of, on Hutchinson's reputation, 43-44; Franklin publicly abused by Wedderburn on account of, 44-45.

Wheelock, Rev. Eleazar, 373.

Wheelock, John, 373-374.

Whigs, beginning of party called, 295, 339.

Whiskey rebellion, the, $132-133$.

White, Hugh Lawson, 340, 34I.

White murder trial, Webster's speech in, 397 .

Whittier, J. G., 309.

Wickliffe, Charles A., 356.

Wildcat banking in early New England, 13-22.

Wilkes, John, 64, 65.

Wilkins, Isaac, 107.

William and Mary College, 151, 327, 328,333 .

Williamsburg, state capital of Virginia removed from, 162 .

Wilson, James, 114.

Winsor, Justin, $390 \mathrm{n}$.

Wirt, William, 303, 334.

Witherspoon, President, of Princeton, 106.

Wood, Rev. Samuel, 368 .

Woodbury, Levi, 294.

Wormeley, Ralph, on Charles Lee as author of "Letters of Junius," 96.

Writs of Assistance, 26.

Wythe, George, 151, 157, I61, 206.

\section{$\mathrm{X}$}

X. Y. Z. despatches, the, 210.

\section{Y}

Yates, Robert, 119.

Yeomanry of England, comparison of, and corresponding class in France, I45-148.

Yorke, Sir Joseph, opinion of, concerning Charles Lee, 88. 


\title{
HISTORY OF THE UNITED STATES
}

\section{From the Compromise of 1850}

\author{
BY JAMES FORD RHODES
}

In Four Volumes. Cloth. 8vo. \$10.0o, net

"It is the one work now within reach of the young American student of to-day in which he may learn the connected story of the great battle that resulted in the overthrow of slavery and the rededication of the republic to unsullied freedom. In no other publication are these facts so concisely, so fully, and so well presented, and the student who makes careful study of this work will fully understand, not only the actual causes which led to the war, but he will know how gradually they were developed from year to year under varying political power, until the nation was ripe for the revolution. . . . Taking the work all together, we regard it as the most valuable political publication of the age, and the intelligent citizen who does not become its careful student must do himself great injustice." - The Times, Philadelphia, Pa.

"There is the same abundant and almost exhaustive collation of material, the same simplicity and directness of method, the same good judgment in the selection of topics for full treatment or for sketchy notice, the same calmness of temper and absence of passionate partisanship. He may fairly be said to be a pupil of the Gardiner school, and to have made the great English historian a model in subordinating the literary element to the judicial." - The Nation.

\section{A SHORT HISTORY OF GERMANY}

\section{By ERNEST F. HENDERSON}

A.B. (Trinity), M.A. (Harvard), PH.D. (Berlin)

Author of "A History of Germany in the Middle Ages"

In Two Volumes. Cloth. 8vo. \$4.0o, net

Vol. I. 9 A.D. to 1648 A.D.

Vol. II. 1648 A.D. to 1871 A.D.

"This work is in the form of a continuous narrative, unbroken by monographs on particular institutions or phases of Germany's development, but covering the whole subject with a unity of treatment such as has seldom been attained by earlier writers in the same field. In this respect, at least, the book is unique among popular histories of Germany in the English language." - Review of Reviezus.

"It has remained for Mr. Henderson to treat at all effectively in English in a short space the development of the German nation as a progressive and ever mobile whole. And to appreciate the difficulty of the task before him, we have only to glance at the powers and forces that work out their expression if not their fulfilment, on German ground and through German institutions." - Commercial Advertiser, New York.

"Of very decided importance. .... We have never seen in English a more satisfactory record of the story of Germany - one that fulfilled as many requisites as does that under review. Mr. Henderson writes in a straightforward, unstrained style which makes his work easy reading." - Baltimore Sun.

\section{THE MACMILLAN COMPANY}




\title{
THE AMERICAN COMIMONWEALTH
}

\author{
By JAMES BRYCE \\ Author of "The Holy Roman Empire," M.P. for Aberdeen
}

\section{In two volumes. Third edition, completely revised throughout, with additional chapters. Crown 8 vo. Cloth, gilt tops}

Vol. I. The National Government - The State Government. Pp. $x i x+724$.

Vol. II. THe PARTy System - PuBurc Price, \$1.75, net $\begin{array}{ll}\text { Social Institutions. Pp. 904. Price, \$2.25, net } & \end{array}$

The two volumes in a box, $\$ 4.00$, net

"It is not too much to call 'The American Commonwealth' one of the most distinguished additions to political and social science which this generation has seen. It has done, and will continue to do, a great work in informing the world concerning the principles of this government." - Philadelphia Evening Telegraph.

"No enlightened American can desire a better thing for his country than the widest diffusion and the most thorough reading of Mr. Bryce's impartial and penetrating work." - Literary World.

\section{THE LIFE OF NAPOLEON I.}

INCLUDING NEW MATERIALS FROM THE BRITISH OFFICIAL RECORDS

\section{By J. H. ROSE, M.A.}

Author of "The Revolutionary and Napoleonic Era, 1789-1815," etc.

Illustrated. In two volumes. Cloth. 8vo. \$4.00, net

"Mr. Rose seems to have read everything bearing on his subject, and to discriminate wisely as to the value of the authorities. In particular he has for the first time thoroughly explored the English Foreign Office Records. The information which he derives from them serves in general to confirm the views held by the majority, at least of competent judges. English policy during the great struggle which arose out of the French Revolution was, as it has usually been, honest and sound in purpose, but too often ill managed and weak in its methods.... Mr. Rose excels in the difficult art of stating complicated matters briefly and yet clearly.... Best of all, perhaps, is his chapter on the schemes for colonial expansion which Napoleon set on foot as soon as France was at peace; it is admirably clear, and contains much that will be new to most readers. Mr. Rose is equally successful in his military narrative, a subject wh ich is especially difficult to treat both briefly and lucidly. He always sees the essential points and never includes needless details, though here and there an additional fact would have made the whole more easy of comprehension. .... We do not know where else to find a series of great military operations described so well and also so concisely. .... Nothing could be better than the pages in which he describes and comments on the death of Pitt." - The London Times.

"The author is John Holland Rose, the well-known English historian, and his biography of Napoleon Bonaparte will have little difficulty in taking rank as the best in the language. Napoleon is, to Mr. Rose, neither a demi-god nor an ogre, but a wonderfully brilliant man, whose complete, but on the whole, attractive personality is made the subject of a penetrating and luminous psychological study." - The Philadelphia Press.

\section{THE MACMILLAN COMPANY}



\% 